\title{
Camp Elizabeth, Sterling County, Texas: An Archaeological and Archival Investigation of a U.S. Army Subpost, and Evidence Supporting Its Use by the Military and "Buffalo Soldiers"
}

\author{
Maureen Brown \\ Center for Archaeological Research \\ Jose E. Zapata \\ Center for Archeological Research, University of Texas at San Antonio \\ Bruce K. Moses \\ Center for Archaeological Research
}

Follow this and additional works at: https://scholarworks.sfasu.edu/ita

Part of the American Material Culture Commons, Archaeological Anthropology Commons, Environmental Studies Commons, Other American Studies Commons, Other Arts and Humanities Commons, Other History of Art, Architecture, and Archaeology Commons, and the United States History Commons

Tell us how this article helped you.

This Article is brought to you for free and open access by the Center for Regional Heritage Research at SFA ScholarWorks. It has been accepted for inclusion in Index of Texas Archaeology: Open Access Gray Literature from the Lone Star State by an authorized editor of SFA ScholarWorks. For more information, please contact cdsscholarworks@sfasu.edu. 


\section{Camp Elizabeth, Sterling County, Texas: An Archaeological and Archival Investigation of a U.S. Army Subpost, and Evidence Supporting Its Use by the Military and "Buffalo Soldiers"}

\section{Licensing Statement}

This is a work produced for the Texas Department of Transportation (TxDOT) by the report producer. TxDOT and the report producer jointly own all rights, title, and interest in and to all intellectual property developed under TXDOT's contract with the report producer. The report may be cited and brief passages from this publication may be reproduced without permission provided that credit is given to both TxDOT and the report producer. Permission to reprint an entire chapter, section, figures or tables must be obtained in advance from either the Supervisor of the Archeological Studies Branch, Environmental Affairs Division, Texas Department of Transportation, 125 East 11th Street, Austin, Texas, 78701 or from the report producer.

\section{Creative Commons License}

(c) (i) (9)

This work is licensed under a Creative Commons Attribution-NonCommercial 4.0 International License 


\section{Camp Elizabeth, Sterling County, Texas:}

An Archaeological and Archival Investigation of a U.S. Army Subpost, and Evidence Supporting Its $U_{s e}$ by the Military and "Buffalo Soldiers"

\section{Maureen Brown, José E. Zapata, and Bruce K. Moses}

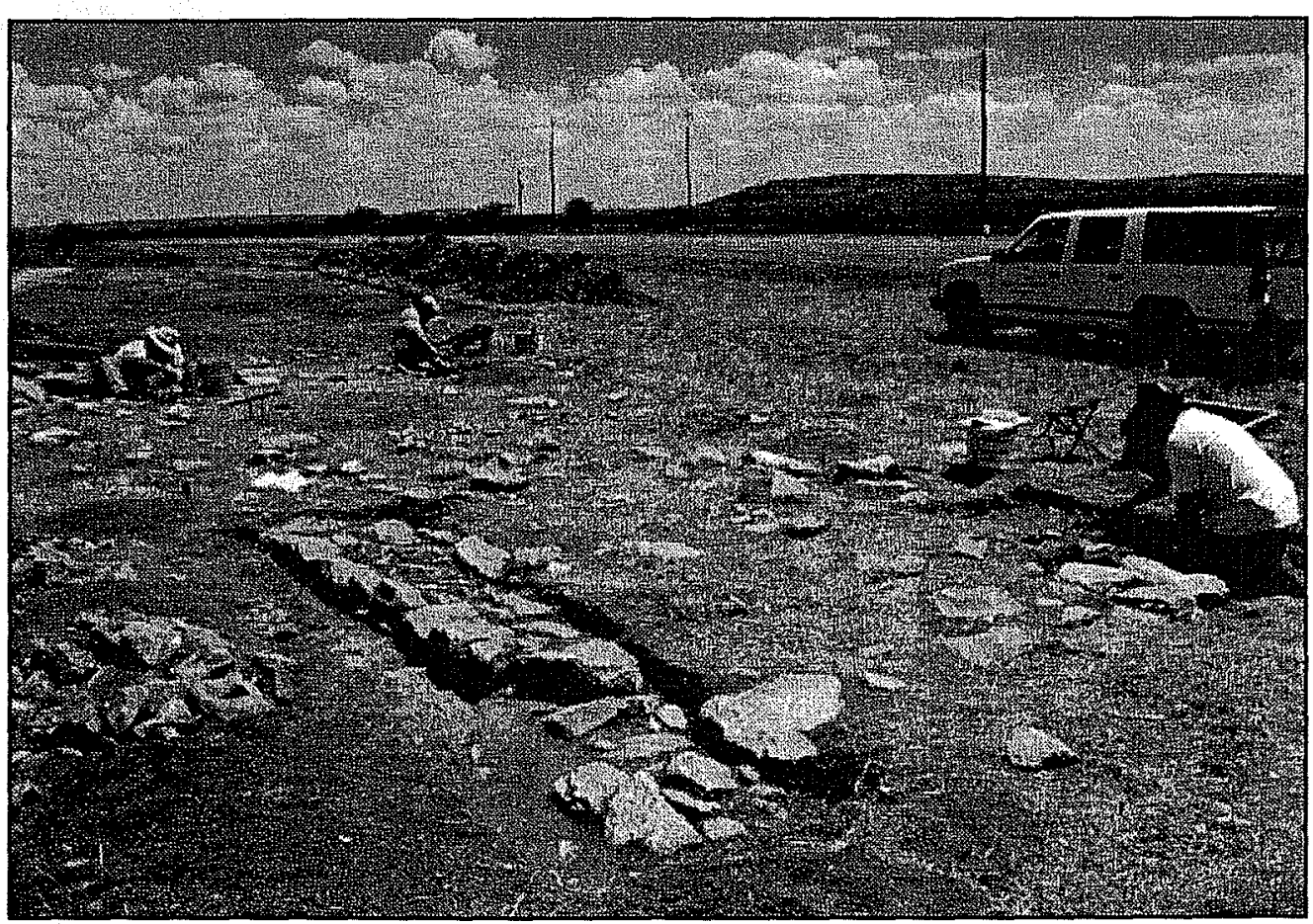

with contributions by Anne A. Fox, C. Britt Bousman, I. Waynne Cox, and Cynthia L. Tennis

Sponsored by:

San Angelo District

Texas Department of Transportation

Archaeological Survey Report, No. 267

Center for Archaeological Research The University of Texas at San Antonio 1998 

Camp Elizabeth, Sterling County, Texas: An Archaeological and Archival Investigation of a U.S. Army Subpost, and Evidence Supporting Its Use by the Military and "Buffalo Soldiers"

\section{Maureen Brown, José E. Zapata, and Bruce K. Moses}

with contributions by

Anne A. Fox, C. Britt Bousman, I. Waynne Cox, and Cynthia L. Tennis

Robert J. Hard and C. Britt Bousman Principal Investigators

Texas Antiquities Permit No. 1866

Archaeological Survey Report, No. 267

Center for Archaeological Research

The University of Texas at San Antonio

C) copyright 1998 
The following information is provided in accordance with the General Rules of Practice and Procedure, Chapter 41.11 (Investigative Reports), Texas Antiquities Committee:

1. Type of investigation: Archaeological and archival mitigation

2. Project name: Camp Elizabeth

3. County: Sterling

4. Principal investigator: Robert J. Hard and C. Britt Bousman

5. Name and location of sponsoring agency: Texas Department of Transportation, Austin, Texas 78701

6. Texas Antiquities Permit No.: 1866

7. Published by the Center for Archaeological Research, The University of Texas at San Antonio, 6900 N. Loop 1604 W., San Antonio, Texas 78249-0658, 1998

A list of publications offered by the Center for Archaeological Research is available. Call (210) 458-4378; write to the Center for Archaeological Research, The University of Texas at San Antonio, 6900 N. Loop 1604 W., San Antonio, Texas 78249-0658; e-mail to car@lonestar.utsa.edu; or visit CAR's web site at http://www.csbs.utsa.edu/research/car. 


\section{Abstract}

The Center for Archaeological Research (CAR) of The University of Texas at San Antonio (UTSA) engaged in a two-phase contract with the Texas Department of Transportation (TxDOT) to complete archaeological and archival investigations of the Camp at the Head of the North Concho (41ST111). The camp, known locally as Camp Elizabeth, was a military outpost of Fort Concho in San Angelo, Texas, and is now located approximately nine miles northwest of Sterling City along U.S. Highway 87 . The camp lies within the right-of-way along U.S. 87 that will be impacted by a highway improvement project.

CAR's archaeological and archival investigations confirmed the presence of the former military occupation of the camp during the late-nineteenth century. No evidence supporting a legendary presence of the Texas Rangers at Camp Elizabeth was found. Archival evidence that the Buffalo Soldiers, African-American troops, were stationed at Camp Elizabeth is presented. Archaeological excavations identified numerous features, including a farrier's shop. 


\section{Contents}

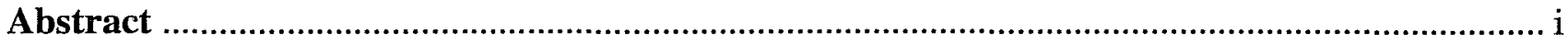

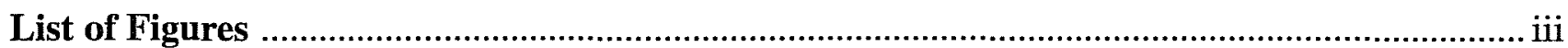

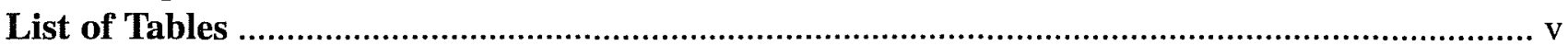

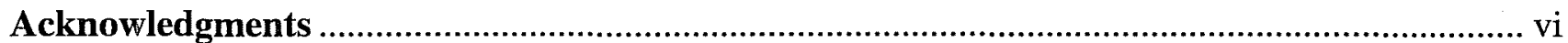

Chapter 1: Introduction

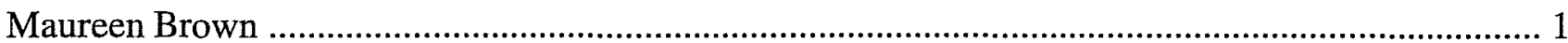

Chapter 2: Project Background

Bruce K. Moses, Cynthia L. Tennis, and Maureen Brown .................................................... 5

Chapter 3: Research Issues

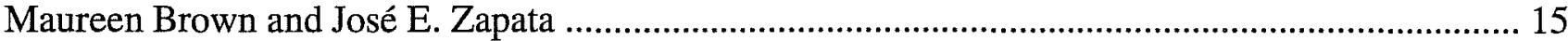

Chapter 4: Archival Investigations

José E. Zapata, I. Waynne Cox, and C. Britt Bousman ............................................................. 19

Chapter 5: Archaeological Investigations

Maureen Brown, Bruce K. Moses, and José E. Zapata ........................................................... 47

Chapter 6: Conclusions and Interpretations

Maureen Brown, Anne A. Fox, Bruce K. Moses, José E. Zapata, and C. Britt Bousma.................. 81

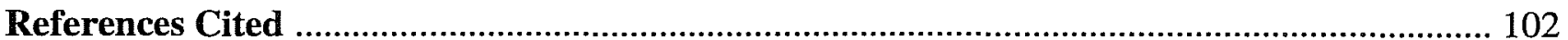

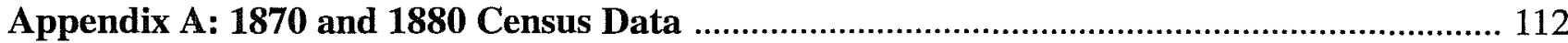

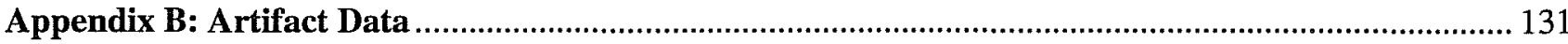




\section{Figures}

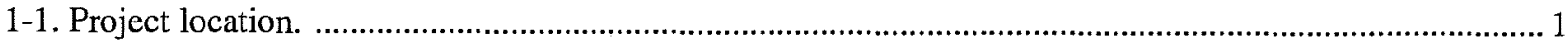

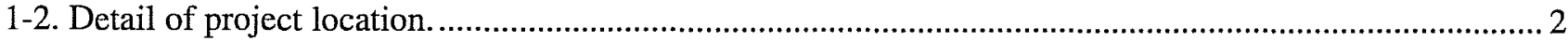

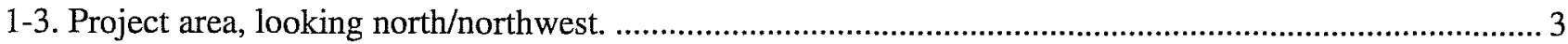

2-1. Vegetation zones in the vicinity of the project area. ........................................................................... 7

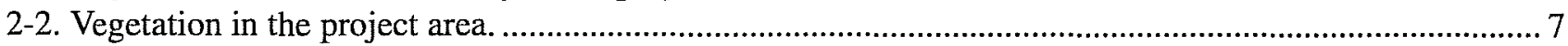

2-3. Plan of Camp Elizabeth as remembered by Kellis. ……………………............................................ 12

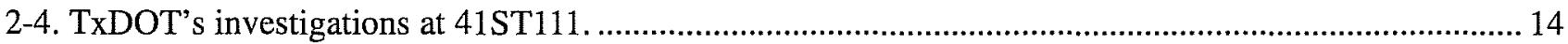

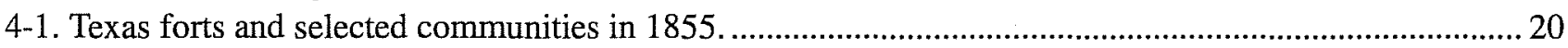

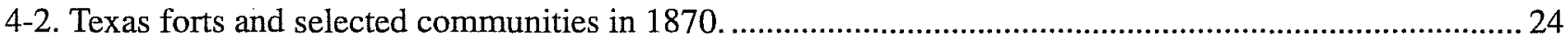

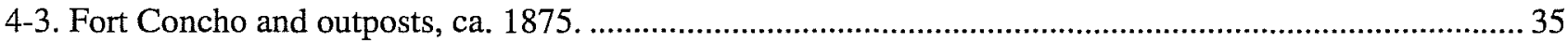

4-4. Ft. Concho Scout Report map of the location of Camp at the Head of the North Concho. ........................ 37

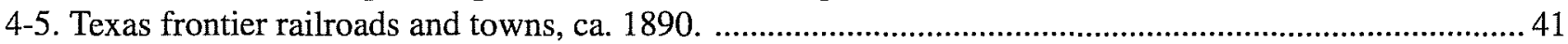

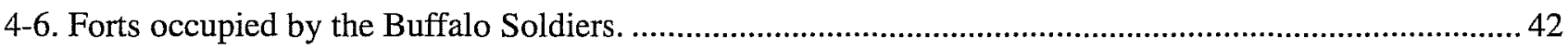

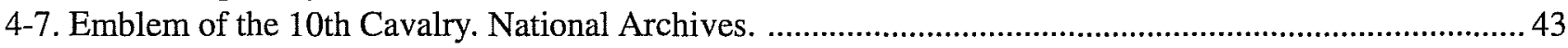

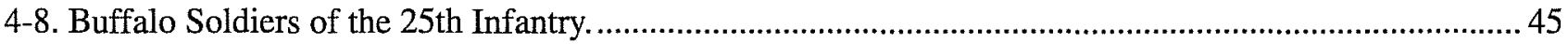

5-1. Site map showing grid in 41ST111 project area, TxDOT previous investigations, CAR's

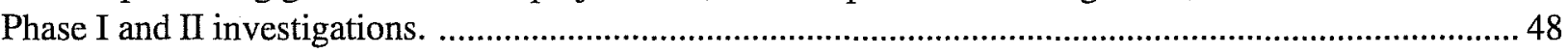

5-2. Site map showing TxDOTs identified Features 1-5 and CAR's excavated units within Features 1

(U77-86, and U89) and Feature 4 (U87-88).................................................................................. 50

5-3. Unit 73 (12 inches bs) showing interior northwest corner of Feature 1. .................................................5 53

5-4. Unit 73, profile of north wall of Feature 1 within U73 ................................................................... 54

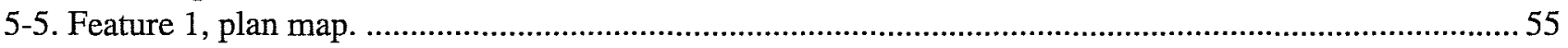

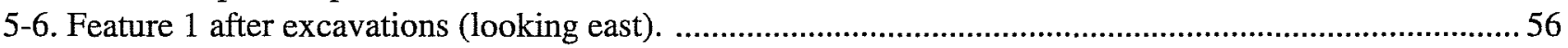

5-7. Feature 1, exposure of north and west walls (looking southeast). ...........................................................56

5-8. Feature 1, exposure of the east wall and the northeast corner (looking south) ........................................ 57

5-9. Bladed area excavations showing the locations of identified anomalies A1-A70 ...................................6 60

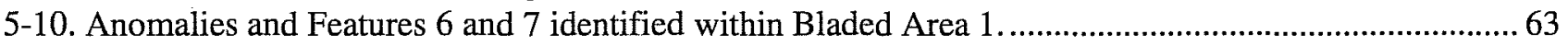

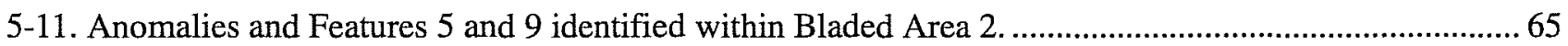

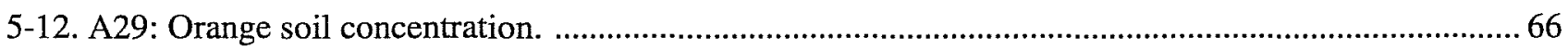

5-13. A30: 12d cut nail with grommet and window glass. ...........................................................................6 66

5-14. Anomalies and Features 2, 3, 4, and 10 identified within Bladed Area 3.............................................. 67

5-15. Anomalies and Features 1, 11, 12, and 13 within Bladed Area 4. ....................................................... 69

5-16. Feature 12 (A57): ash, charcoal, limestone, and artifact concentration ................................................ 70

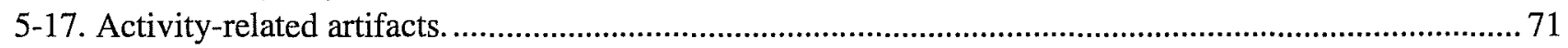

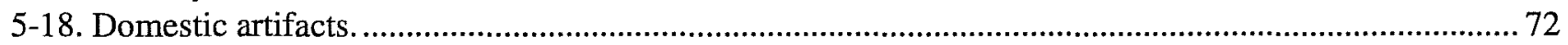

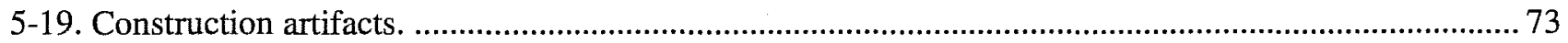

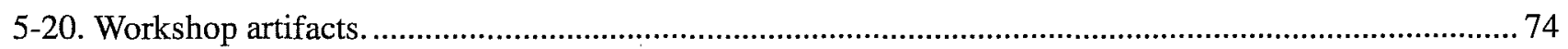

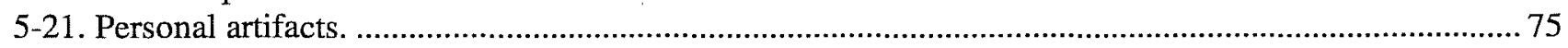

5-22. Plan map of surface features identified on the adjacent property. ………………................................ 76

5-23. Feature 14, southeast corner foundation (looking northeast) ……………………………………......... 78

5-24. Feature 15, center wall foundation (looking west). ........................................................................... 78

5-25. Feature 18, large limestone mound (looking northeast). ....................................................................... 79

5-26. Feature 18, southwest corner foundation (looking east, southeast), ....................................................... 79

5-27. Limestone rock with possible incised cross-shaped mark located near Feature 19................................. 80

5-28. Limestone slabs in area where two soldiers may have been buried. ........................................................ 80 


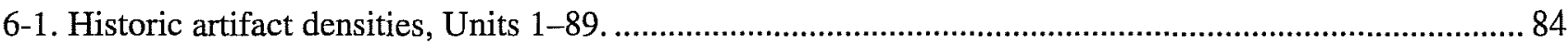

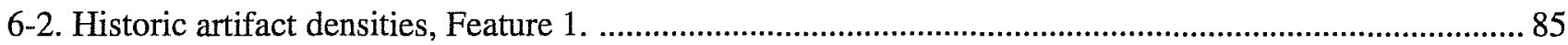

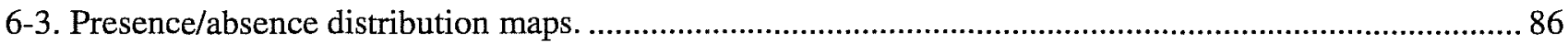

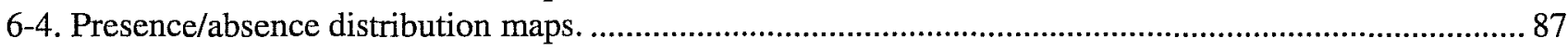

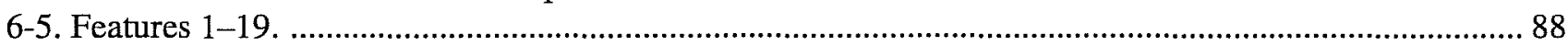

6-6. Diagram of Camp Elizabeth as remembered by W. F. Kellis....................................................... 89

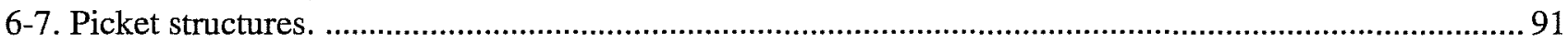

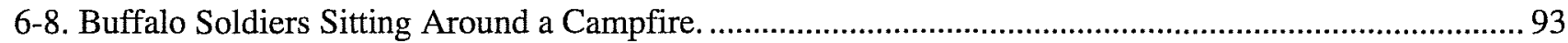

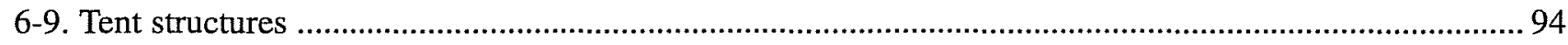

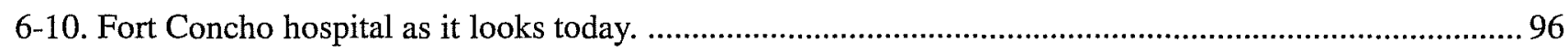

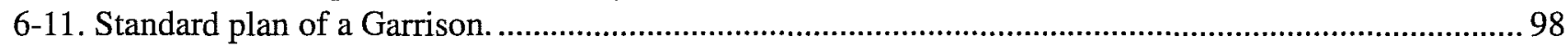

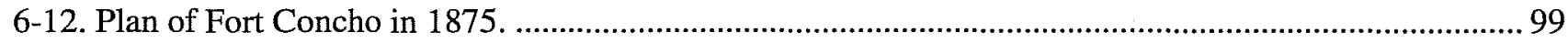

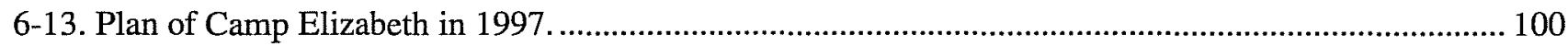




\section{Tables}

4-1. Early Texas Forts: First Line of Frontier Defense, from North to South

4-2. Early Texas Forts: Second Line of Frontier Defense, from North to South

4-3. Early Texas Forts: Post-Civil War Period Posts, from North to South

4-4. Number and Percent of Soldiers Birth Locations by Census Year

4-5. Race of Soldiers by Census Year....

4-6. Average Age of Soldiers by Birth Place and Census Year ................................................................... 33

4-7. Number of Soldiers by Birth Place and Race, 1880 ...................................................................... 34

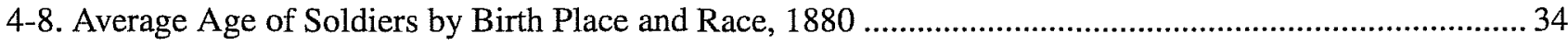

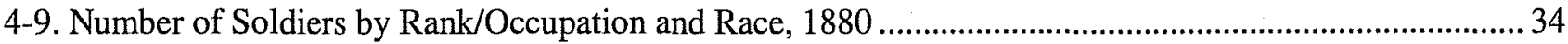

4-10. Subpost at the Head of the North Concho River, Texas-Fort Concho Detachments ........................... 40

5-1. Anomalies Identified in the Bladed Areas (ca. 3-5 inches bs) .........................................................61 61

5-2. Total Artifacts from Project Area Per Artifact Category ............................................................. 70

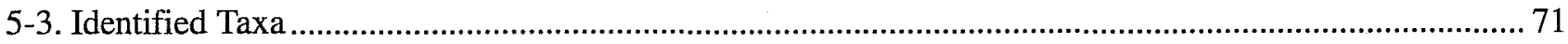

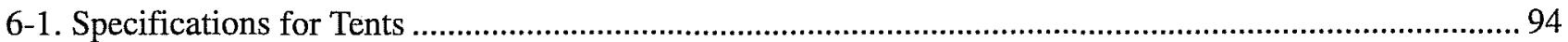

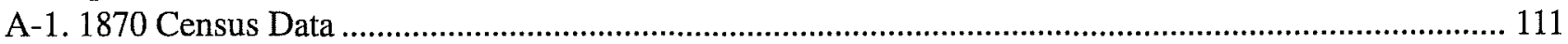

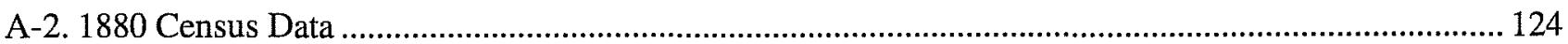

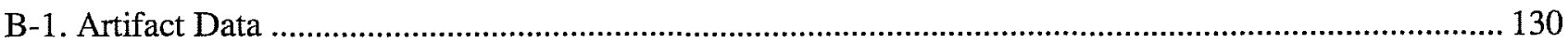




\section{Acknowledgments}

For the undertaking of the archaeological and archival mitigation of the Camp at the Head of the North Concho (41ST111) to be successful, the cooperation of a great many individuals and organizations was necessary. Many individuals with the Department of Transportation (TxDOT) contributed immensely in helping complete the Camp Elizabeth project. We would like to thank the TxDOT Environmental Affairs Division office in Austin, especially Nancy Kenmotsu and John W. Clark. Special thanks goes to Nancy Fisher at the TxDOT San Angelo District Office for devoting a lot of time and effort with us in the field during the two phases of archaeological fieldwork. Thanks also go to her husband, Lyndal Fisher, and her son, Travis, a Boy Scout, who volunteered with us and received hours toward his archaeology merit badge. We would also like to thank all who contributed to this effort at the TxDOT San Angelo offices. We cannot thank the TxDOT Sterling City office enough for all their kindness and support during the field operations, especially the transportation maintenance supervisor, Shorty Radde, and his staff, Mary Alice Brown, Joe Rodriguez, and Herbert Pendley. They were always there to lend a hand and provided us with a port-a-potty, ice to fill our cooler, a lawnmower, a weed eater, and the maintainer. Thanks also to James Bell and Ron Blaylock, the crew that brought the gradall out for a day from the TxDOT San Angelo offices.

Others in the Sterling City area deserve special thanks for their support and kind hospitality. Thanks to property owner, Mr. Wilkinson, of Midland, and his ranch manager, Cotton Frizzell, for allowing us to document the existing structures remaining from the camp that were located on his property. Also thanks to Jim and Kay Davis, for their hospitality, for providing information on the area and its residents, and for showing us their museum and collections. Thanks to Mr. Caldwell, the property owner in the adjacent southern portion of the project area. Thanks to the local Texas Historical Commission Archaeological Steward for this district, Larry Riemenschneider, of Miles, Texas, for visiting us at the site with his family and showing an interest in the camp.

Thanks to the staff at Fort Concho, in San Angelo, Texas, who contributed to this effort, especially Kathy Roland, curator of artifacts, who also came to visit us during the fieldwork along with Sue Hall, a member of the Concho Valley Archaeological Society.

Thanks also go to the many people who assisted our endeavors in the archival research. A special thank you to Ms. Meg Hacker, Assistant Archivist, National Archives, Fort Worth Division who readily made available many rolls of microfilm from the Archives. Thanks also to the very helpful and supportive staff of Fort Concho, including the executive director, Robert Bluthardt. We appreciate the extra time and effort given by Elizabeth Lemons, the Fort Concho archivist and librarian. Thanks to John Anderson, Preservation Officer, and other helpful staff members at the Texas State Library and Archives Commission. Thanks to John Manguso, curator/ director of the Fort Sam Houston Museum for providing us useful information on the military. Thanks to Ed Johnson, now of the Institute of Texan Cultures, for sharing his information and knowledge of Buffalo Soldiers in Texas. Thanks to the staff at Dataplex, Inc., especially Glenn March, who was very courteous and duplicated the microfilm quickly.

We would like to thank the director of CAR, Dr. Robert Hard, the principal investigator for the Camp Elizabeth Project; Dr. Britt Bousman, associate director of CAR; and Cindy Tennis, CAR director of small projects. Of course, no project could be successful without a dedicated and hard-working archaeological staff that endured $108^{\circ}$ temperatures and no shade: Tony Lyle, Cory Broehme, Jeff Durst, Ed Johnson, and Richard Jones. Thanks also go to our crew that volunteered a couple of hours on the way to the TAS conference to map in remaining shots, shoot more photographs, and to check on the site: Dave Nickels (who ran the TDS with the assistance of Donna Edmondson), Chris Horrell, Tony Lyle, Richard Jones, and Preston McWhorter. 
Individuals who contributed to the analysis and reporting included the following. Robert J. Hard and C. Britt Bousman supervised the archaeological and archival investigations and report preparation. Barbara Meissner analyzed the faunal remains. We thank Anne A. Fox and John W. Clark (TxDOT) who helped us with some of the artifact identifications. Chris Butler and Barbara Meissner assisted Bruce K. Moses with drafting and artifact illustrations. The authors thank Marcie Renner and Brett A. Houk for the generous time and effort spent editing the report. Heide Castañeda, Debora Weksler, Donna Edmondson, and Kevin Henselka helped with preparation of the final report. 



\section{Chapter 1: Introduction}

\section{Maureen Brown}

\section{Project Description}

This report presents the results of an archaeological and archival mitigation project conducted on the Camp at the Head of the North Concho site (41ST111), Sterling County, Texas (Figure 1-1). The work was initiated by the Texas Department of Transportation (TxDOT) under a contractual agreement with the Center for Archaeological Research (CAR) of The University of Texas at San Antonio (UTSA), in 1997-1998.
The Camp at the Head of the North Concho, referred to as the Camp on the North Concho by TxDOT (Kenmotsu et al. 1997), was an outpost of Fort Concho in San Angelo, Texas. It served as a temporary camp site, possibly for Texas Rangers and the U.S. Army. Although the site's historical name is the Camp at the Head of the North Concho, the camp is popularly known as "Camp Elizabeth."

Portions of Camp Elizabeth are located within the TxDOT right-of-way on the north side of U.S. 87,

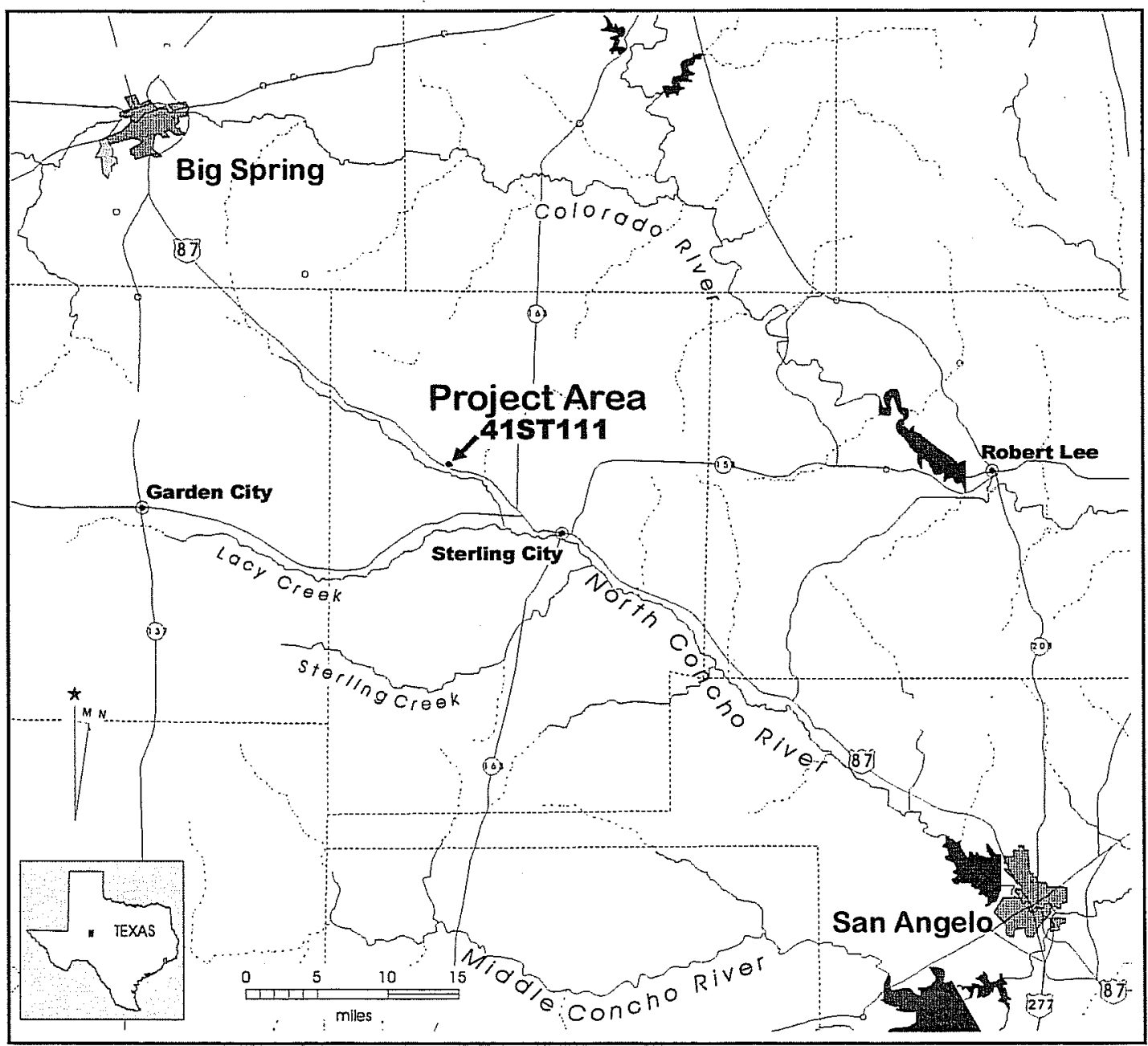

Figure 1-1. Project Location 
approximately 9.5 miles north of Sterling City (Figure 1-1) (Kenmotsu et al. 1997:13). The site extends north toward McIntyre Butte and south toward the North Concho River (Figures 1-1 and 1-2). Both the northern and southern site boundaries are on private property. During its peak period of occupation in the $1880 \mathrm{~s}$, the camp would have covered an estimated 12.5 acres of land. The surveyed area lying within the highway rightof-way includes approximately 2.24 acres of this original camp.

Little is known about the many U.S. Army sub-post camps that supported the western frontier forts in Texas. These camps were part of a frontier military system designed to protect and extend AngloAmerican settlement in Texas westward (Kenmotsu et al. 1997:21). After the Civil War, many of the forts and outpost camps were built, maintained, and occupied by the U.S. Army, including African-
American troops, whom the Native Americans called "Buffalo Soldiers." Aside from local lore, the occasional story in local papers, and brief mentions in a few history sources (Daniels 1976; Dearen 1993; Tyler et al. 1996(1):936), little is known about Camp Elizabeth.

Members of the Concho Valley Archaeological Society and the Midland Archaeological Society first mapped the site in December 1976. Camp Elizabeth was surveyed and recorded as the Camp on the North Concho (41ST111) by archaeologists from the Environmental Affairs Division of TxDOT in early 1997. Archaeologists from TxDOT concluded that the Camp on the North Concho met criteria A and D for the National Register of Historic Places (NRHP) because it was found to have intact features within the right-of-way, and because no other U.S. Army camps of Buffalo Soldiers have been subjected to

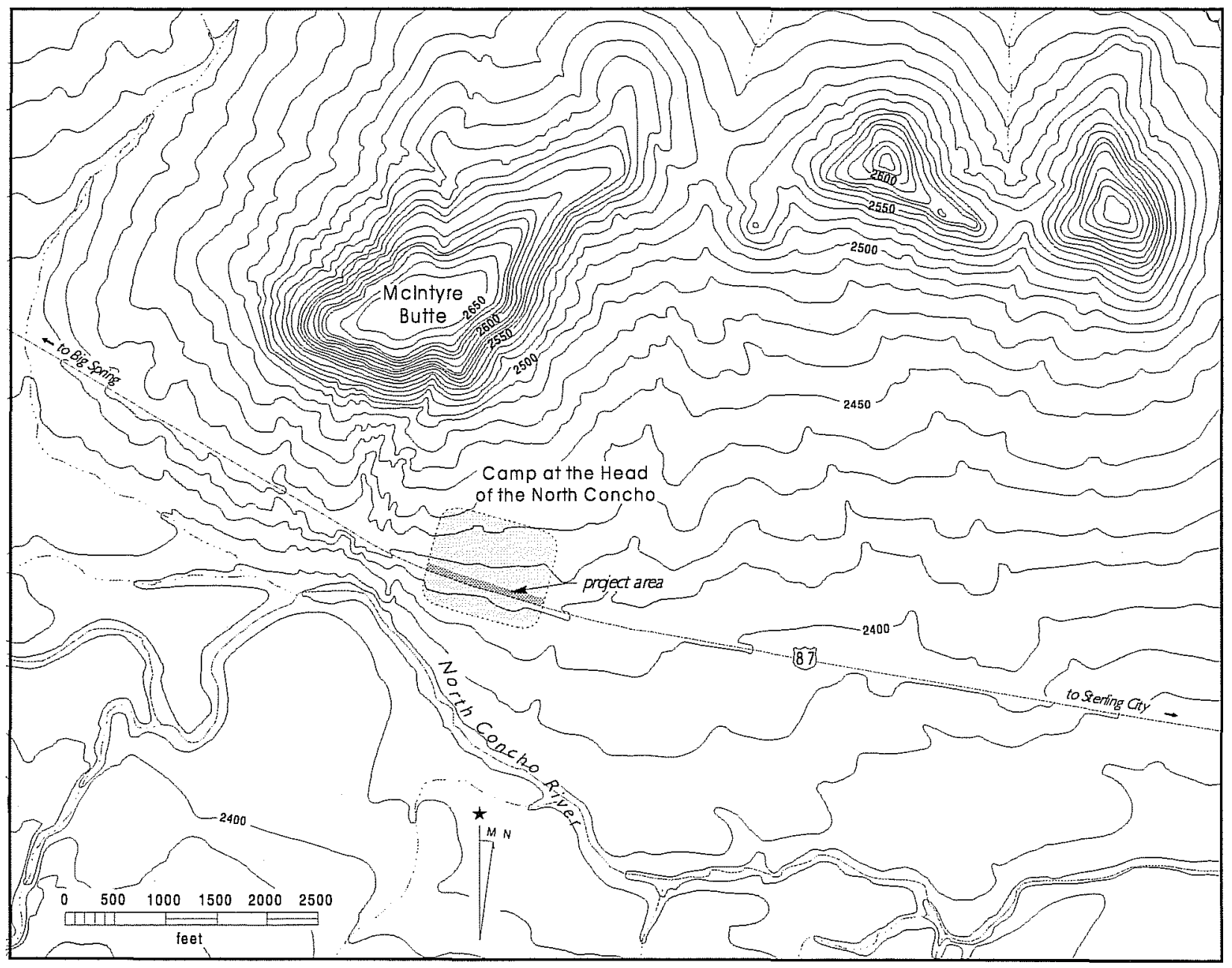

Figure 1-2. Detail of project location. 
archaeological investigation (Kenmotsu et al. 1997:21). Subsequently, CAR entered into two contractual agreements with the Environmental Affairs Division, TxDOT Austin Offices, and the Environmental Affairs Division, TxDOT San Angelo District Offices, to perform archaeological and archival mitigation on the camp.

The camp is situated within the only remaining portion of two-lane roadway on U.S. 87 between San Angelo and Lubbock (Figure 1-3). The current investigations were deemed necessary by TxDOT because the site will be impacted by a highway-widening project (Kenmotsu et al. 1997:1). TxDOT's construction plans include upgrading the present two-lane portion of U.S. 87 in Sterling County, which has two 3.7-m (12-ft) traffic lanes with 3.0-m (9.84-ft) shoulders, into a fourlane divided highway in Sterling and Glasscock counties (Kenmotsu et al. 1997:1). The proposed widening would require an additional $30.5-45.7 \mathrm{~m}$ (100-150 ft) of right-of-way, which has been acquired (Kenmotsu et al. 1997:1). The archaeological project was performed under the Antiquities Code of Texas, the National Historic Preservation Act, a Memorandum of Understanding between TxDOT and the Texas Historical Commission (THC) and with the Programmatic Agreement signed by the THC, the

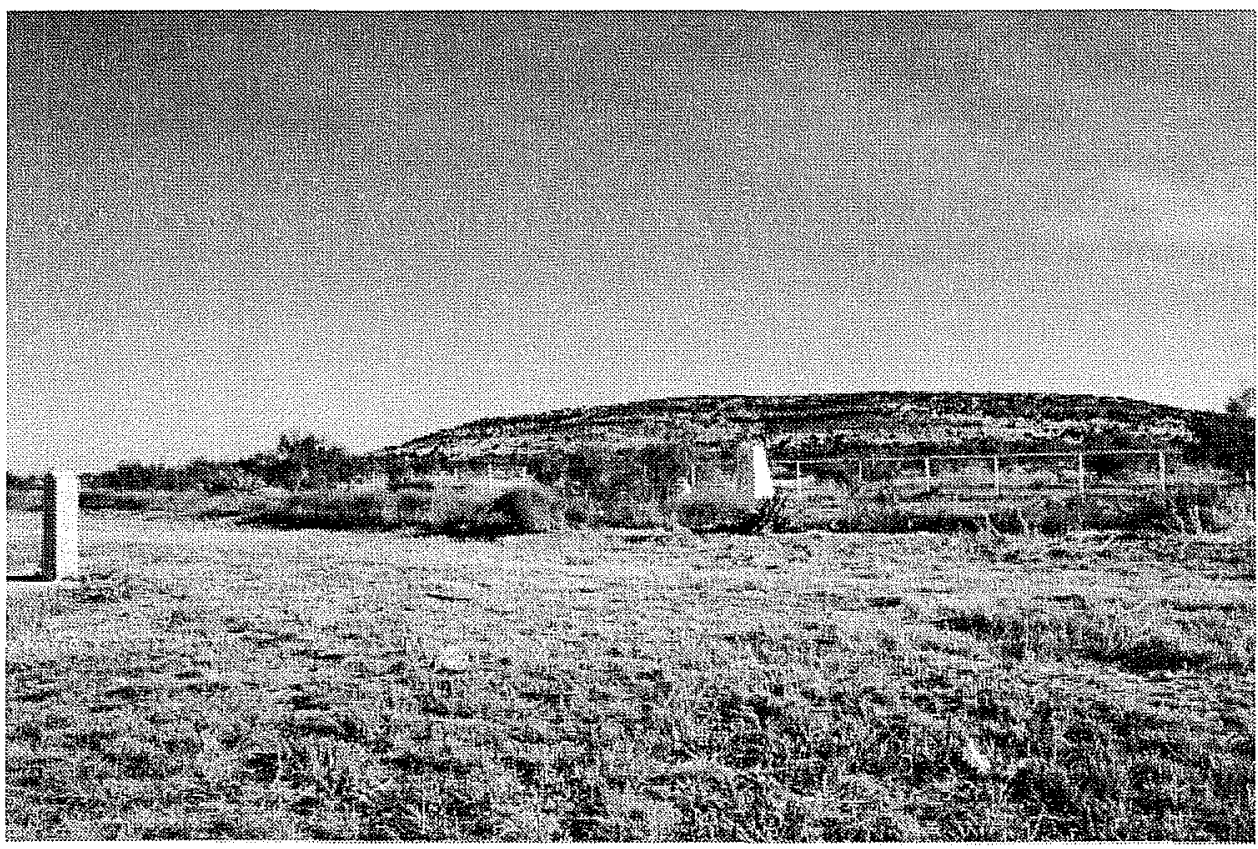

Figure 1-3. Project area, looking north/northwest. 1936 monument on the left, McIntyre Butte and the right-of-way fence in the background.
Advisory Council on Historic Preservation, the Federal Highway Administration, and TxDOT (Kenmotsu et al. 1997:21).

TxDOT funded the investigations through state appropriation and acted as the agency for oversight management of archaeological compliance-related activities during both phases of mitigation. All CAR investigations were performed under Texas Antiquities Permit number 1866, issued by the THC. The report conforms to the Council of Texas Archaeologists reporting standards, and those of the Secretary of the Interior's Standards and Guidelines: Archaeology and Historic Preservation. CAR's archaeological staff conducted the archaeological mitigation investigations in two phases: July 23-29 and August 12-16, 1997. Robert J. Hard served as principal investigator and C. Britt Bousman acted as co-principal investigator. Daily field operations were directed by the project archaeologist, Maureen Brown. Archival research was conducted by José E. Zapata.

The purpose of the archaeological investigations conducted by CAR was to obtain a representative sample of the artifactual material and any associated features beneath the surface to provide information about the use of the site and its previous occupants.

During the course of the archaeological mitigation project CAR excavated 89 units within a $600-\mathrm{x}-120$ $\mathrm{ft}$ area. Phase I included excavation of $7220-x-20$ inch test units within a 30$\mathrm{ft}$ grid, and four additional 20-x-20-inch units placed within a previously located feature (designated Feature 1 by TxDOT). Phase II fieldwork included placing 11 more units of various sizes within Feature 1 and two units within Feature 4. Gradall and maintainer excavations were monitored for cultural remains and features. All 
mapping with the Total Data Station was completed during Phase II fieldwork. CAR staff also received permission from the landowner to map surface features on the adjacent property that were believed to be part of the camp site.

During the course of the archaeological mitigation project, CAR excavated the remains of a probable farrier's shop (Feature 1). The remains are comprised of roughly shaped limestone foundations, measuring approximately $30 \times 20 \mathrm{ft}$. The north, west, and east walls were intact at the foundation level; however, field investigations found no evidence for the south wall, which is believed to have been impacted by the initial construction of U.S. 87 in 1939. Artifacts associated with a farrier's shop were found in association with the feature. Excavated units yielded historic artifacts that suggest a late nineteenth-century military presence at the site. In the bladed area three inches below the surface, several features (70 anomalies) were present.

From September 1997 to May 1998, investigations by CAR staff included analysis of the artifacts recovered from fieldwork, archival mitigation, and report preparation. Archival investigations by CAR staff have resulted in an enormous amount of information about the role of the Texas Rangers, the U.S. Army on the western frontier, and the western fort outposts in Texas. The investigations, however, have especially focused and retrieved information on the camps that were the isolated outposts of the military forts in west Texas. These documents have also given us insight into the lives of the military personnel, both officers and enlisted men, many of whom were Buffalo Soldiers.

The artifacts, records, and other materials recovered or generated during the archaeological and archival investigations are curated at Fort Concho, San Angelo, Texas. Fort Concho is a restored fort and museum facility, owned and operated by the city of San Angelo, with a full-time curatorial staff.

\section{Report Organization}

This report consists of six chapters outlining the work performed at Camp Elizabeth by CAR. This chapter is an introduction to the report. Chapter 2 discusses the environmental and cultural setting for the project area and previous archaeological investigations on the site. The research issues addressed during the project including the archival and archaeological goals are the focus of Chapter 3. Chapter 4 consists of the methodology and results of the archival research. This chapter presents the geographic setting, the role of the Native Americans, the nature of the Texas Rangers' involvement, the position of the U.S. Army in the westward expansion of Texas, the military purpose of the forts and their outpost camps, and the role of the Buffalo Soldiers. Chapter 5 includes a discussion of the archaeological investigations that were undertaken at the site of the Camp at the Head of the North Concho (41ST111). The methodology utilized prior to and during the mitigation of the site and the archaeological results are discussed. Included in this chapter is an analysis of the artifacts and features recovered from the site. Chapter 6 offers a summary and the interpretations and comparisons of the archival and archaeological investigations. Additionally, comparative archaeological research with other similar camp and fort sites are included. Two appendixes are included in the report: archival census data and the artifact database. 


\section{Chapter 2: Project Background}

\section{Bruce K. Moses, Cynthia L. Tennis, and Maureen Brown}

\section{Environmental Setting}

Bruce K. Moses

\section{Introduction}

Camp Elizabeth (41ST111) is located in northwestern Sterling County, near the intersection of three major physiographic regions. The camp rests in the northwestern portion of the Edwards Plateau along the western edge of the Live Oak Mesquite Savannah (Barnes 1976). Camp Elizabeth also lies near the southern edge of the Mesquite Plains, an area of the broad Rolling Plains physiographic region. The Mesquite Plains are characteristically undulating and rolling hills, interspersed occasionally with dissecting canyons, especially along the major rivers and their tributaries (Fenneman 1931:54).

As the camp's formal name implies, the nearest extant water is the North Concho River, located approximately 1,000 feet southwest of the camp. Lacy Creek drains a substantial portion of the region to the south and joins the North Concho approximately five miles southeast of the camp. The North Concho is a perennial stream originating in southern Howard County approximately two miles north of the Glasscock County line (Tyler et al. 1996:1039). In the past, many of the perennial streams on the Edwards Plateau were fed by springs originating from the caprock escarpments. Now, overuse of the regional aquifer has many of the springs to go dry. Although water tables have lowered since the camp was last occupied, cool, pure water continues to flow in the North Concho.

W. F. Kellis, a Sterling County pioneer, described the North Concho River as it looked in 1887:

It was then the most beautiful stream I ever saw. The water was as clear as crystal and ran the year round over its pebbly bed. Deep pools of clear, cold water existed where fish sported in great numbers. Beavers in large colonies built their lodges and dams from San Angelo up the river to the head of the living water in the $U$ [Ranch] pasture [Dearen 1993:125-126].

The location also served as a militarily strategic position from which to observe indigenous groups and travelers who were attracted by this permanent source of water.

\section{Climate}

The climate of Sterling County is generally classified as subtropical semiarid, but the county can also share characteristics with humid East Texas. The primary influence on the region's climate is the interaction of three main air masses: the warm, Maritime tropical (mT) air mass which brings moisture from the Gulf of Mexico; the warm, dry Continental tropical (cT) air mass which originates in the Pacific and is carried across Mexico; and the Continental polar (cP) air mass originating in interior Canada (Botts et al. 1974; Wiedenfeld et al. 1970).

Winters are usually cool while summers are typically hot and humid, with temperatures varying from a minimum daily average of $30.5^{\circ} \mathrm{F}$ in January to a maximum daily average of $95.2^{\circ} \mathrm{F}$ in July. During the summer, hot daytime temperatures prevail for a considerable period, with occasional thundershowers providing temporary relief. The area experiences an average of 235 frost-free days per year, between March 25 and November 15. Between November and March, frequent northers effectively close off moisture from the Gulf of Mexico, creating a relatively dry period.

Average yearly rainfall in Sterling County is 18.38 inches, but this amount can vary widely. Clear skies prevail over 78 percent of the summer and 63 percent 
in the winter, while average daytime humidity ranges from 50 percent in January to 41 percent in July. The majority of precipitation in Sterling County comes during the spring and summer, primarily in the form of convective showers and thunderstorms. High precipitation averages of 2.64 inches for May and 2.74 inches in September are held in check by lower averages of 0.71 inches in December and March. In unusually wet years, the majority of the rainfall comes from excessive downpours. Periods of drought occur rather frequently (Blum 1977).

\section{Geology and Geomorphology}

The geological formations in the area are principally composed of Cretaceous age materials and consist primarily of the Fort Terrett and the Segovia formations of the Edwards Group and the Antlers Sand formation. The local geomorphological development has been the result of extensive erosional modification of the Llano Estacado plateau. In the region of the northwestern Edwards Plateau, this has resulted in the headward erosion of the draws over time, forming escarpments typically several hundred feet high. The resultant badlands topography typically averages one to six miles wide and is characterized by steep slopes, isolated mesas and peaks, and narrow V-shaped drainages (Bamforth 1988; Fenneman 1931; Gould 1906). The limestone bluffs in the immediate vicinity of the project area are also of Cretaceous age and are principally composed of interbedded limestone and calcareous marl of the Fredericksburg and Trinity groups. These are gently rolling to steep, benched hills and ridges where the limestone bedrock is near the surface.

The three principal soil groups underlying Camp Elizabeth are the Angelo, Rioconcho, and Broome series. Generally, these are deep, gently sloping, moderately to slowly permeable, loamy soils that are found on both uplands and bottom lands. The surface on which the camp is located gently slopes an average of three percent from north to south, a slope typical of the southern portions of the Rolling Plains (Thomas 1975).
The camp is mainly situated on a Broome silty clay loam $(\mathrm{BrB})$, which was formed from calcareous, loamy sediments of an ancient eolian outwash. Broome silty clay loam has a friable, moderately alkaline surface layer averaging seven inches in thickness. The soil is well drained with a moderate amount of runoff, and the root zone can be easily penetrated by plant roots. Although some small areas of Broome silty clay loam are utilized for cultivation, it is most typically used as range land for cattle grazing (Blum 1977).

Another important soil type is the Rioconcho series which makes up the floodplain of the North Concho River near the camp. These are deep, loamy soils composed of calcareous, clayey and loamy alluvial sediments. Rioconcho silty clay loam has a deep surface layer averaging 16 inches in thickness and is moderately well drained. The available water capacity in Rioconcho soils is high and the root zone is deep, giving a very high potential for native range plants. The major limiting factor in this regard is low rainfall (Blum 1977).

\section{Flora}

The principal vegetation community in the area of the camp is Mesquite-Juniper Brush (Figures 2-1 and $2-2$ ). This vegetation community commonly includes lotebush (Ziziphus obtusifolia), shin oak (Quercus sinuata), sumac (Rhus), Texas prickly pear (Opuntia lindheimeri), tasajillo (Opuntia leptocaulis), kidneywood (Eysenhardtia texana), agarita (Berberis trifoliolata), redbud (Cercis canadensis), yucca (Yucca), silktassel (Garrya ovata), sotol (Dasylirion), persimmon (Diospyros), juniper (Juniperus), and mesquite (Prosopis) (Texas Parks and Wildlife 1998).

Mesquite-Hackberry Brush/Woods can be found in the North Concho floodplains near the camp. Additional plants in this community include walnut (Juglans), catclaw (Acacia greggii), woolybucket bumelia (Bumelia lanuginosa), and whitebrush (Aloysia gratissima). Also present in the nearby Mesquite Shrub/Grasslands are evening primrose (Caylophus drummondianus) and cholla (Opuntia) (Texas Parks and Wildlife 1998). 


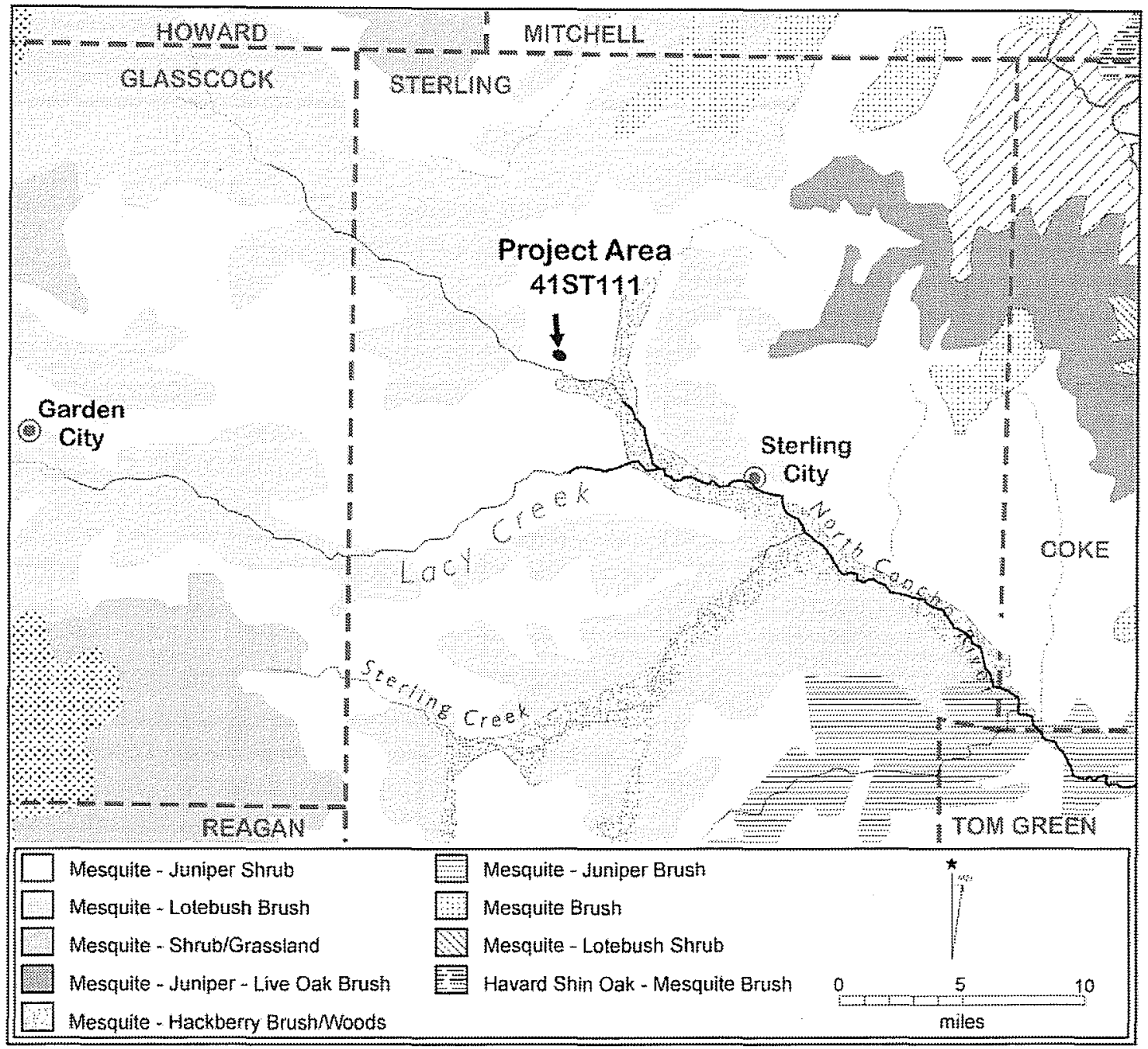

Figure 2-1. Vegetation zones in the vicinity of the project area.

Figure 2-2. Vegetation in the project area.

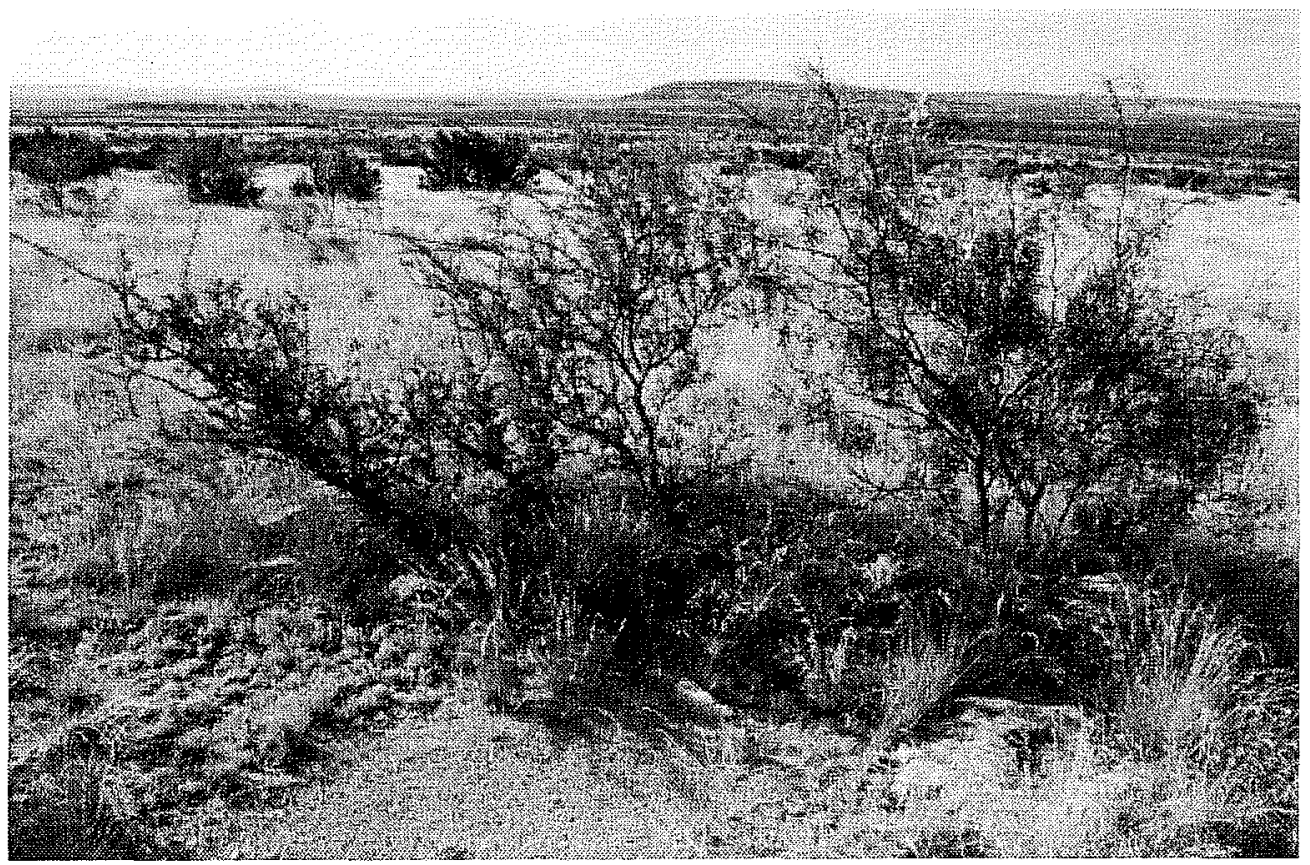


Grasses are also a major native vegetation group in Sterling County and have thus influenced the type of fauna attracted to the area. Tall and mid-grasses are the dominant species and include little bluestem (Andropogon scoparius), big bluestem (Andropogon gerardii), sand bluestem (Andropogon paucipilus), sideoats gramma (Bouteloua curtipendula), Indian grass (Sorghasttum nutans), switchgrass (Pancium virgagum), hairy gramma (Bouteloua hirsuta), blue bramma (Bouteloua gracilis), Canada wild rye (Elymus canadensis), and western wheatgrass (Agropyron smithii) (Gould 1975).

Although mesquite is typically considered an invasive shrub permitted by overgrazing, its early presence in the region has been well documented by numerous historical accounts, well before overgrazing by cattle was considered a problem in the late 1800 s (e.g., Creel 1986; Loomis and Nasatir 1967; Marcy 1850; Williams 1953). Land-use practices over the last 100 years have increased the occurrence of secondary vegetational growth, including mesquite, juniper, and other shrubs. Foremost among these has been overgrazing in the region by domestic stock, clearing away of native vegetation, the cessation of grassland fires, plowing, and fencing (Hester et al. 1989).

\section{Fauna}

The abundant grasses in the area have given the region a close affinity to the Southern Great Plains, and this fact is amplified by early historic accounts of bison herds in the region. In 1683, Spanish frontier captain Domínguez de Mendoza led a party of soldiers through the area and camped near the junction of the Concho and Colorado rivers. During the six weeks he remained in the area, he and his party killed over 4,000 bison (Chipman 1992, 69-70).

In 1834, explorer and naturalist Dr. Gideon Lincecum described the area as he passed near the Concho River.

I could see from my still elevated position a vast district of the far-reaching plain below. Right ahead, not exceeding a mile below, and lying across the direction $I$ intended to extend my evening walk, was a large drove of perhaps a half a million buffaloes, which were quietly grazing on every part of the grand expanse [Lincecum and Phillips 1994:231-234].

Lincecum went on to describe other mammals in the vicinity of the Concho.

I saw much game, a gang of wolves, a few antelopes, and many hares-all muley rabbits. We crossed one little prairie dog town and I saw several rattlesnakes lying about the dog-burrows, and some owls. I saw some wild horses scouring the plains occasionally, ... gangs of deer were constantly visible in many directions all day; flocks of prairie hens would be seen running swiftly from my path [Lincecum and Phillips 1994:231-234].

Even as late as 1874 , an adventurous mail contractor named August Santleben described the area near the headwaters of the Concho as being "occupied by droves of buffalo whose numbers could not be computed with certainty" (Santleben 1994 [1910]:176-177). He described the range of the American bison in Texas as not extending "very far south of the Concho River . . . and they were only found in great numbers about fifty miles above that limit" (Santleben 1994 [1910]:176-177). Santleben (1994 [1910]:177-178) offered an explanation for their great numbers around the Concho:

They were not molested in that region to any great extent ... on account of the risk of encountering Comanche Indians, who occasionally hunted in that region in defiance of the United States troops which garrisoned Fort Concho. But their presence acted as a restraint, consequently the noble animals were partially protected in the area about thirty miles wide, where they were in great numbers.

Other historical accounts in the region mention the presence of white-tailed deer, antelope, beaver, prairie dog, gopher, gray squirrel, red squirrel, jack rabbit, cotton-tailed rabbit, red fox, skunk, numerous birds, and snakes, particularly the rattlesnake. Predators in the region included mountain lions and other wild cats, black bear, coyotes, and wolves (Notson 1974:6-7). 
The rivers were said to abound with catfish, trout, bass, and several varieties of perch. Various types of turtles were noted as well as an abundance of "a beautiful pearly muscle [sic] which probably gives the name to the streams ... can be found anywhere along the banks" (Notson 1974:6-7).

\section{Cultural Setting}

\section{Cynthia L. Tennis and Maureen Brown}

The following is a brief overview of the cultural background necessary to set the foundation for interpreting the archaeological and archival investigations of Camp Elizabeth in a regional context. Included are brief discussions of the prehistory of the western Edwards Plateau, historic Native American occupation, and the Euro-American settlement of the project region. An initial discussion of the military occupation and the U.S. Army's role in this area is also included. This is a preliminary discussion to set the stage for the archival mitigation investigation that constitutes the focus of Chapter 4 .

\section{Prehistoric Cultural History}

The project area lies at the extreme northwest edge of the Central Texas archaeological region, bounded on the north by the Southern Plains region and on the west by the Western Desert region. While these archaeological boundaries are unquestionably arbitrary, this brief synthesis of the cultural prehistory of the project area follows the most agreed-upon regional specification, that of the Central Texas Plateau-Prairie region (Black 1989; Creel 1990; Kenmotsu et al. 1997). Central Texas prehistory has been divided into periods based on technological and adaptive change (Black 1989): Paleoindian (ca. $11,000-8000$ B.P.), Early Archaic (ca. $8000-5000$ B.P.), Middle Archaic (ca. 5000-3000 B.P.), Late to Terminal Archaic (ca. 3000-1150 B.P.), and Late Prehistoric (ca. $1150-350$ B.P.).

The Paleoindian period is traditionally described as a time when small, highly mobile bands of hunters exploited herds of now-extinct large mammals over vast areas of North, Central, and South America. Clovis and Folsom points-the finely flaked, fluted projectile point markers for the earliest portion of this period- have been found in association with extinct faunal remains at sites in Texas. Although these earliest inhabitants of North America probably passed through Sterling County, archaeological evidence of their presence in the area is, as of yet, lacking (Meltzer and Bever 1995; Prewitt 1995).

The Archaic encompasses a 7,000-year period of hunting-and-gathering adaptations following the Pleistocene. In the Early Archaic period, population densities were probably low and consisted of small, highly mobile bands exploiting a wide variety of resources (Weir 1976). Sites were concentrated along the southern edge of Balcones Escarpment presumably because of the concentration of springs and streams (Black 1989; Collins 1995; Johnson and Goode 1994; McKinney 1981; Story 1985).

During the Middle Archaic, burned-rock midden features were widespread in central Texas (Hester 1970 , 1991), suggesting the formation of a more specialized economy and increased population density (Weir 1976). By the Late Archaic period, the frequency of burned-rock midden features declines and the presence of bison bones among the archaeological faunal assemblages increases, suggesting another shift in subsistence strategies as mesic conditions return (Collins 1995; Dillehay 1974; Johnson and Goode 1994).

The Late Prehistoric period in central Texas is characterized by major cultural changes. While a division of the Late Prehistoric into two phasesAustin and Toyah-is generally accepted (Black 1989; Prewitt 1981; 1985), the temporal placement of this break is less clear (Collins 1995; Johnson and Goode 1994). During the earlier Austin phase, arrow points and presumably the bow and arrow were adopted. The greater use of protected rockshelter locations, the postulated decline in population density, and the increase in the frequency of burials with embedded projectile points archaeologically attributed to this time suggest increased intergroup conflict (Black 1989; Prewitt 1985; Shafer 1977; Skinner 1981). Toward the end of the Late Prehistoric period, the 
appearance of blade technology, the Perdiz point, and ceramics over wide areas of Texas have been termed horizon markers for the Toyah phase (Black 1989; Collins 1995; Johnson 1994; Ricklis and Collins 1994). The cause of these changes is not well understood. Some investigators suggest that a migration into the area occurred, possibly as a result of the return of the bison, while others view the changes as resulting from increased interactions with peoples from outside central Texas (Assad and Potter 1979; Black 1989; Harris 1985; Huebner 1991; Johnson 1994; Prewitt 1985; Shafer 1977; Steele and Assad-Hunter 1986).

\section{Overview of Historic Indians}

There is very little information on Native Americans in the study areas at the time of contact. Unlike other areas of Texas that were frequently visited by Spanish explorers and missionaries who recorded their encounters with aboriginal inhabitants, this area at the edge of the Llano Estacado does not appear to have been included on early expedition routes. By the late sixteenth or early seventeenth centuries, the native inhabitants had begun to be displaced by pressures from both the Spanish moving up from the south and the Lipan Apache moving into Texas from New Mexico and Colorado (Hester 1989:83). The Lipan Apache subsistence was also based on hunting and gathering, but with a strong emphasis on raiding that forced an alliance between the local native groups and Spanish settlers. Their cultural material-which includes arrows tipped with steel points, spears, shields, and guns-reflects this aggressive lifeway. Records of peaceful negotiations, usually associated with trade, do exist (Payne 1970), but Apache raids continued in south Texas and the Lower Pecos into the 1880s (Hester 1989).

Eventually even the Apache were forced to seek European protection, as the militaristic Comanche invaded the southern plains in the eighteenth and nineteenth centuries (Hester 1989). The Comanche became such a dominant factor in the southern plains that a large section of Texas, including the project area and most of what is now known as the Texas Panhandle, was known as Comancheria. During the late-eighteenth and mid-nineteenth centuries, the Kotsoteka, one of possibly a dozen Comanche bands, dominated a large region of the state that included the study area (Kenmotsu et al. 1997).

\section{Historic Period}

One of the major objectives of this investigation was to conduct a thorough archival search of all records pertaining to the military use of Camp Elizabeth, with the goal of separating documented fact from commonly held perceptions. This information is presented in detail in Chapter 4 . Therefore, the following is a brief summary of the local history surrounding the camp as outlined in Kenmotsu et al. (1997).

The influx of Anglo-American settlers into the Comanche-held areas heightened the frequency of conflicts. By 1849 the U.S. Army had begun to construct military forts at the edge of the frontier to protect settlers from Indian raids. This effort was quickly followed by the construction of another line of frontier forts as settlers pushed farther west. In 1852, six companies of state-paid rangers had been commissioned to assist the U.S. Army in protecting against the continuing Indian raids. These Texas Rangers served along the Mexican border and the Indian frontier and intermittently occupied the frontier forts after they were abandoned during the Civil War (Kenmotsu et al. 1997). Local history suggests that Texas Rangers were using the area that later became the Camp at the Head of the North Concho as early as 1853 (Daniels 1976).

After the Civil War the U.S. Army returned to Texas and completed the line of frontier forts. These later forts included Fort Concho, which was built in 1867 to offer protection to settlers who began coming to the area prior to the Civil War. African-American cavalry troops from Fort Concho, the Buffalo Soldiers, were using the Camp at the Head of the North Concho as a training camp by the middle of the $1880 \mathrm{~s}$ (Kenmotsu et al. 1997). At this time the camp consisted of officers' quarters, a hospital, a farrier's shop, and assorted rock corrals (Daniels 1976). Daniels (1976:6) depicts a rough diagram of Camp Elizabeth as 
remembered by W. F. Kellis (Figure 2-3), a local surveyor and settler of Sterling City in the late $1880 \mathrm{~s}$ who suggested the camp consisted of the following:

officers' quarters, hospital, farrier shop, and rock corrals. The buildings were made of ruble stone and mud mortar. The farrier shop and hospital were each about twenty by fifty feet in size, and the officers' quarters were about twenty by thirty feet. The soldiers slept in tents which were stretched near the officers' quarters. There were two target butts, one for long distance practice and other for short distance shooting. The presence of a parade ground between the camp and the river suggests that these defenders of the frontier knew the advantages that skilled horsemanship provided in combating the Indian menace. Water was obtained from a spring on the North Concho River, which was only a few hundred feet from the fort. There were a great many negro troops stationed at the post [Daniels 1976:5-6].

The modern name for the outpost "Camp Elizabeth" is a misnomer, although the origin of the name is amusing. Around 1936, the historical society was inquiring locally about the camp name prior to their placing of the present stone monument at the site. The owner of the U Ranch, George McEntire, Sr., received a telephone call about the camp. His son George $\mathrm{H}$. McEntire, Jr. said "there's not a word of truth in the name on the marker" (Dearen 1993:125). Apparently, the story goes that his father asked a friend of his the name of the camp and the friend suggested he give them his grandmother's name, "Frances Elizabeth Daniel." The friend then suggested he "Call'em up and tell'em that J. Frank Dobie said it was Camp Elizabeth" (Dearen 1993:125).

\section{Historic and Modern Uses of Camp Elizabeth}

The Camp at the Head of the North Concho was abandoned by the military in 1886 and became part of the privately owned U Ranch. The intact buildings became the hiding place for "crooks, loafers, and other objectionable characters" so the owner of the ranch dismantled the roofs of the buildings and gave rocks in the walls to the Kellis family who took them and built a small dam across the North Concho (Daniels 1976:6). Today only foundation stones of these structures remain (Kenmotsu et al. 1997).

For many generations after the military abandoned the camp, local settlers, ranchers, and the traveling public have been interested in the old limestone foundation ruins barely visible on the site's surface. Throughout the years, the camp has had historic and modern uses that have affected the physical remains and cultural integrity of the military occupation of the site. Included in these impacts are many years of artifact collecting activities by individuals. Additional modern impacts have included both the initial construction of U.S. 87 in 1939 and the construction of the present highway.

The camp has been directly affected by the highway construction in several ways. U.S. 87 bisected the middle of the site in an east-west direction separating what was supposedly the Parade Ground from the tent camp ground area and the rest of the site. In 1936 the Commission of Control for Texas Centennial Celebrations Placed a State of Texas Centennial Marker for "Camp Elizabeth" on the north side of U.S. 87 within the vicinity of the camp. Additionally, a paved turnout road was placed on U.S. 87 so the marker could be read by the traveling public. Aside from the road construction, fencing and fire berms were constructed in the right-of-way within the site. A minor impact to the site within the right-of-way included occasional grass maintenance. Much of the former camp is located on private property on land adjacent to the U.S. 87 right-of-way. Several limestone features, probably representing former buildings, can be seen on the surface. Recently this area has been impacted by a gravel road, oil derricks and pads, and a pipeline.

\section{History of Investigations}

\section{Maureen Brown}

This section discusses the previous archaeological investigations at Camp Elizabeth (41ST111). The first documented archaeological investigation at the camp included a visit by the Concho Valley Archaeological 


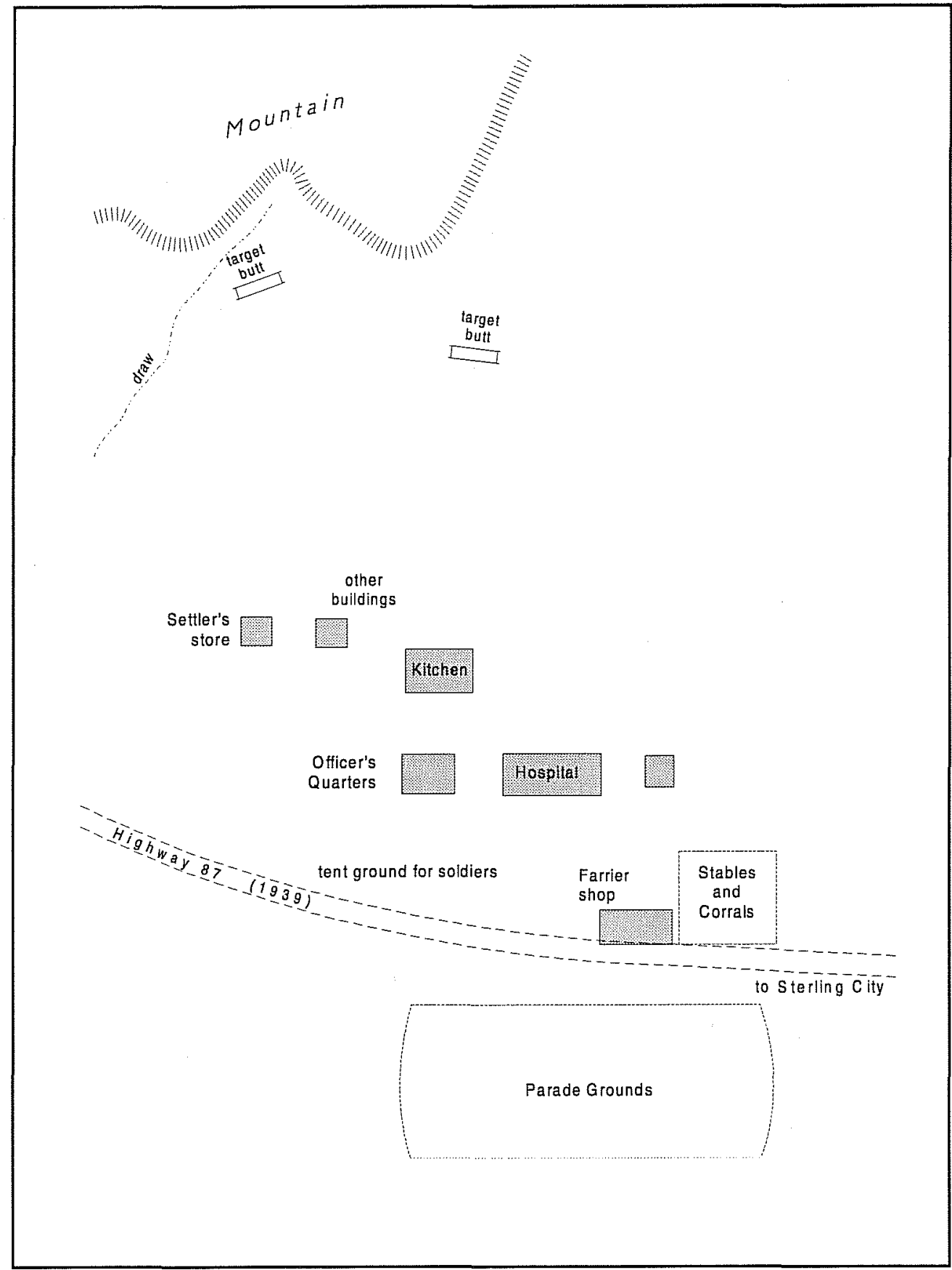

Figure 2-3. Plan of Camp Elizabeth as remembered by Kellis (adapted from Daniels 1976). Spelling and punctuation have been retained from the original.

During that visit, the groups took measurements on four of the clusters of roughly shaped limestone foundation rocks that were visible on the surface. The southeastern building which they called Building 1 measured $9.0 \mathrm{~m}(29.5 \mathrm{ft})$ along the south wall and $4.3 \mathrm{~m}$ (14.1 ft) along the west wall, although the walls were not clearly distinguishable. Center rock alignments also indicated the building was divided into two rooms. Building 2 lay approximately $8.0 \mathrm{~m}$ $(26.3 \mathrm{ft})$ to the north from the northwest corner of Building 1. Foundation walls were not obvious, but rough measurements of the rocky mound measured $3.5 \mathrm{~m}$ (11.5 ft) x $3.4 \mathrm{~m}$ $(11.2 \mathrm{ft})$. Building 3 , approximately $36 \mathrm{~m}$ to the west, was the largest of the buildings and measured ca. $8.8 \mathrm{~m}$ $(28.9 \mathrm{ft})$ east-west and $8.25 \mathrm{~m}$ (27.1 ft) northsouth, and may have contained several dividing walls suggesting four rooms. Building 4 lay ca.

Society and the Midland Archaeological Society during December 1976 (Kenmotsu et al. 1997:7). A two-page description of their work without drawings can be found in the Camp Elizabeth file in the Fort Concho Library and Archives.
$12.6 \mathrm{~m}(41.3 \mathrm{ft})$ from the northwest corner of Building 3. Structural rock foundations were visible on all four walls and measured $3.72 \mathrm{~m}$ (12.2 ft) east-west along the south wall and $3.84 \mathrm{~m}(12.6 \mathrm{ft})$ north-south.

In February 1997, Daymond Crawford of TxDOT's Environmental Affairs Division in Austin conducted 
a pedestrian survey of a three-mile stretch of right-ofway along U.S. 87 that included the remains of the camp site, recorded as 41ST111, Camp on the North Concho (Kenmotsu et al. 1997:11). On February 2-4, 1997, Nancy Kenmotsu and Daymond Crawford of the TxDOT Environmental Affairs Division in Austin and Nancy Fisher from the TxDOT San Angelo District Office recorded and mapped a portion of the site (Kenmotsu et al. 1997).

TxDOT's methodology included establishing a temporary datum on the fence that had been recently erected along the north edge of the new right of way. A site plan map was produced using a plane table, alidade, and stadia rod. Surface concentrations of roughly shaped rectangular limestone blocks, measuring 10 to $80 \mathrm{~cm}$ in length, were recorded and mapped as Features 1-5 (Figure 2-4). A metal detector was used in and around the surface features to detect possible associated concentrations of metal below the surface. Two historic artifacts-a button and a cut nail-were found on the surface, plotted in situ, and collected for curation. Detailed feature maps were completed and included the concentrations of limestone found on the surface, the metal concentrations detected below the surface, and the two artifacts in situ.

Results of the surface and metal detection survey showed that Feature 1 contained the largest concentrations of shaped limestone blocks on the surface and metal detected within the feature. The limestone rocks had evidence of being shaped into rectangular or square tabular blocks, measuring from ca. $25-70 \mathrm{~cm}$ in length, and were believed to have been brought from the slopes of McIntyre Butte, located ca. $400 \mathrm{~m}$ north of the site. The natural limestone rocks at the site were rounded alluvial cobbles measuring less that five centimeters in diameter. It was suggested that the original size of Feature 1 had probably diminished due to disturbances associated with an old fire road to the north and the previous right-of-way fence to the south, both of which had been bulldozed to $15 \mathrm{~cm}$ in depth. No metal or stones were detected in these areas, and the integrity of the associated cultural remains would have been directly impacted by the disturbances. Feature 1 was believed to represent the remains of the farrier's shop as depicted on the surveyor's map (Figure 2-3).

Features 2 and 3 (Figure 2-4) included highly dispersed groups of less than 20 roughly shaped limestone rocks (averaging between $15-25 \mathrm{~cm}$ in diameter) on the surface and intense concentrations of metal detected below the surface. The highest concentration of metal within Feature 2 was detected in the southwestern perimeter. A four-holed metal button was found on the surface in the western portion of the feature and collected. Three cut nails, one of which was collected, were located on the surface in the western margins of Feature 3. Feature 4 was a smaller concentration of limestone rock situated adjacent to a slightly higher ground surface (ca. $5-8 \mathrm{~cm}$ ). Metal detection indicated there was a concentration of metal around the eastern margin of Feature 4. Feature 5 included a small group of four limestone rocks on the surface. Metal detection indicated there were small isolated pieces of metal around Feature 5, unlike the concentrations located in Features 1-4. Although the functions of Features 2-5 were not determined, these areas were designated the "area of tent structures" on the surveyor's map (Figure 2-3).

Additional efforts during TxDOT's survey investigations included limited archival documentation. John W. Clark of TxDOT completed a preliminary cultural background for the area and camp site as well as a compilation of archival resources available on Fort Concho and the Camp on the North Concho.

TxDOT concluded that the Camp on the North Concho (41ST111) meets Criterion A for eligibility for nomination to the National Register of Historic Places because the site has intact cultural features and that it meets Criterion D because no other U.S. Army camps of Buffalo. Soldiers have been investigated archaeologically. TxDOT recommended that archaeological and archival mitigation be conducted on the proposed upgrading of U.S. 87 on the Camp on the North Concho. 


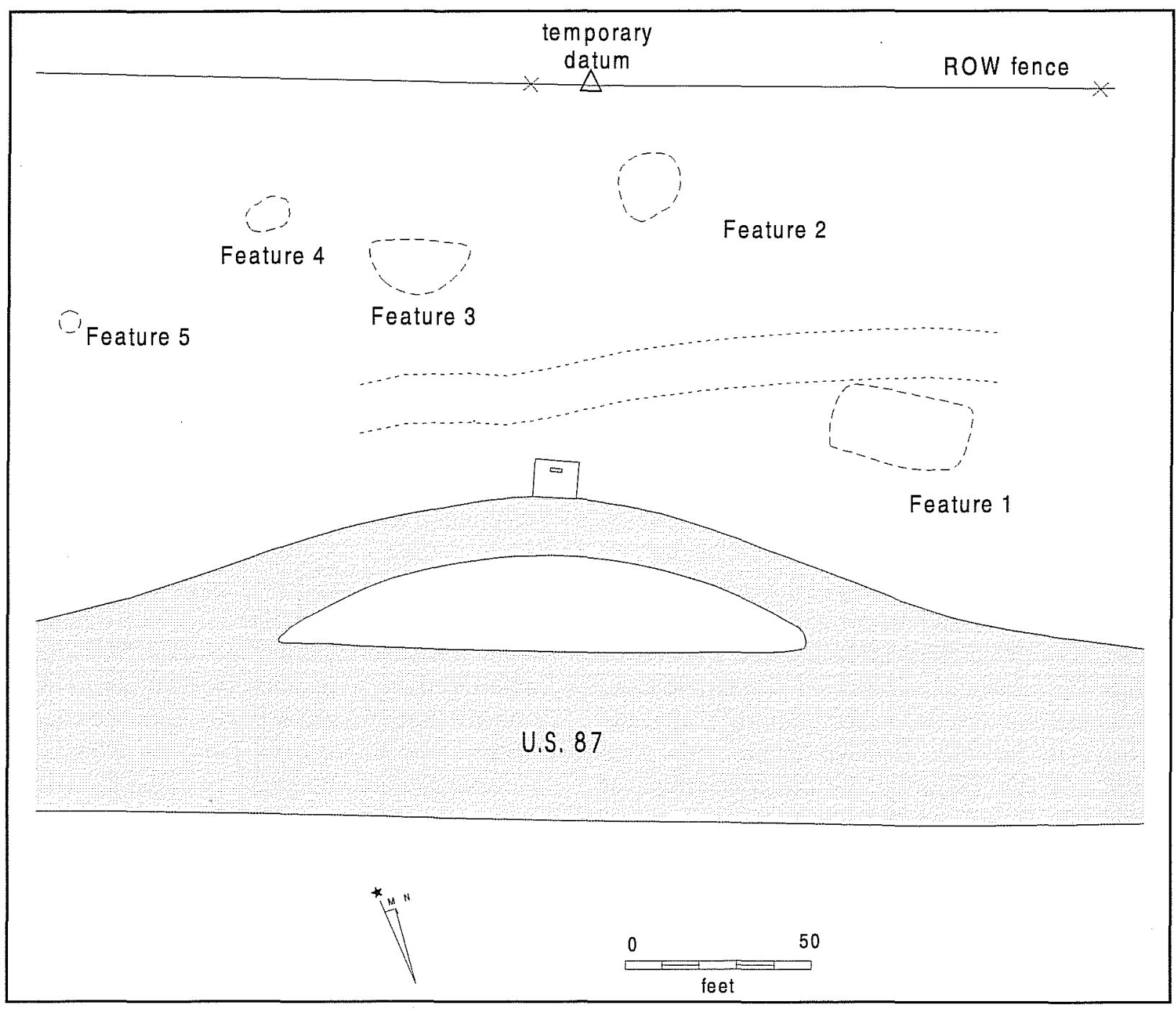

Figure 2-4. TxDOT's investigations at 41STI11. 


\section{Chapter 3: Research Issues}

\section{Maureen Brown and José E. Zapata}

\section{Introduction}

Following the completion of TxDOT's survey, recording, and mapping investigations at Camp Elizabeth (41ST111), recommendations and research issues for subsequent archival and archaeological mitigation were proposed (Kenmotsu et al. 1997). Recommendations by TxDOT suggested the archival research and archaeological investigations should focus on three topics related to the regional setting and occupation of Camp Elizabeth:

1. evidence supporting or disproving occupation and use of Camp Elizabeth by the Texas Rangers;

2. the use of Camp Elizabeth within the context of military activities in the westward expansion of the United States, especially regarding the training and duties of the Buffalo Soldiers; and

3. the role of Camp Elizabeth as an outpost for Forts Concho and Chadbourne.

These research issues form the basis of the archival and archaeological investigations conducted by CAR and are discussed in the following sections.

\section{Archival and Archaeological Research Issues}

Determination of the spatial arrangement of Camp Elizabeth is an important aspect in addressing the three major research issues. Questions concerning how the archival and archaeological evidence compare with each other and with other investigated military sites will be addressed. In particular, how does the spatial/ architectural layout compare, and what patterns can be recognized in the layout? Was the settlement layout of Camp Elizabeth "typical" for a military outpost? How does the intrasite comparison of individual features found at the site compare to similar features at other posts? Do these also compare with the larger forts within the region or elsewhere (e.g., Fort Concho)? Additionally, how do the artifact patterns and functions of activity areas compare with other military sites regionally and elsewhere?

The archival and archaeological evidence must be considered together for final interpretations and discussions. However, because the two sources provide such different types of information, specific research questions are presented separately.

\section{Archival Research Issues}

$$
\text { José E. Zapata }
$$

When considered collectively, the three major research issues relate to one broad topic or unifying theme: the expansion and settling of the west-especially the Southern Plains. Although the research issues are interrelated within this theme, specific concerns were developed for each.

The first two research issues to be addressed are the role of the Texas Rangers and the military function of the camp. The role of the Texas Rangers will be examined within the context of the settlement of the Southern Plains. Rangers' activities specific to the functioning of Camp Elizabeth will be examined, and activities of the state vs. the federal military will also be considered. Specifically, what role did the federal government take in early efforts to respond to the state's need for protection of its property and citizenry? Was this need fulfilled, or did the state (i.e., the Texas Rangers) take over the role?

The U.S. Army undertook numerous separate defensive postures by which a series of forts and posts were strategically placed along the progressively 
westward-moving frontier. These processes will be examined and the army's tactics will be reviewed. The state's ca. 1861 response to frontier defense as the Union troops withdrew and it's continued efforts throughout the Civil War period will be inspected.

We will address the role of Camp Elizabeth as an outpost of Fort Chadbourne and Fort Concho. What was Camp Elizabeth's role during this dynamic period? While considering the activities at Camp Elizabeth, emphasis will be placed on the Buffalo Soldier regiments, but the contribution of the other regiments will also be examined.

The history and role of the Buffalo Soldiers in the settling of the west and specific assignments, especially as they relate to Fort Concho and its subposts, will be addressed in detail. The history of the Buffalo Soldiers serves to introduce the topic of the African-American soldier in the regular army. The Ninth and Tenth Cavalry and the Twenty-fourth and Twenty-fifth Infantry were consistently dogged by attempts to discredit them and discharge their men from active duty. Recent publications on this topic and primary documents will be examined to elucidate the issue, both in general and for Camp Elizabeth specifically. A collection of army records, federal census returns, and scouting reports is available for study.

\section{Archaeological Research Issues}

\section{Maureen Brown}

Previous archaeological investigations had located intact features believed to be related to the military occupation of Camp Elizabeth. The features suggest the camp has research potential for providing important information related to the occupation and use of the site, and specifically its use by the Buffalo Soldiers (Kenmotsu et al. 1997). Considering these factors and TxDOT's recommendations for research issues (listed as 1-3 above), archaeological investigations by CAR focused on answering questions related to the first two issues. The broad archaeological research issues were primarily concerned with the settlement/spatial arrangement of the site in relation to the environment; the use of the site and site features; and evidence providing information on subsistence, socioeconomic status, and ethnicity for various occupation levels of the site.

\section{The Texas Rangers}

The first research question involves the occupation of Camp Elizabeth by the Texas Rangers. According to secondary sources, the Texas Rangers were supposedly the first to occupy the site prior to the Civil War (Daniels 1976; Dearen 1993; Tyler 1996). Archaeological investigations were concerned with recovering artifacts (especially diagnostic artifacts such as buttons and datable ceramic and bottle fragments), and examining possible activity areas or features that would indicate a nonmilitary, pre-Civil War presence at the site. If such Texas Ranger occupation evidence existed, artifacts would then be analyzed by functional classes (i.e., kitchen, architecture, activity, and personal), as utilized by South (1977), to facilitate the interpretation of the site layout, and the function of the associated activity areas and features.

\section{Military Activities}

The second research issue involves the military activities at Camp Elizabeth, especially regarding the camp's occupation and use by the Buffalo Soldiers. In designing the research to address this question, it was necessary to consider the military in general and the Buffalo Soldiers as separate issues.

\section{The Military in General}

Investigations were concerned with the possible recovery of artifacts and features that would be considered typical for the military from ca. 1849-1889. A study of artifact activity areas, isolated or associated with features, would facilitate evidence for the military use of the site. Questions related to this issue include not only the evidence for spatial arrangement of the site and the existence and use of the activity areas, but investigations focused on who used them and why. What would be typical of the U.S. Army equipage 
and structures during this time? Are there different artifact types, styles, or quantity of artifacts for officers vs. enlisted men vs. Buffalo Soldiers? Additionally, are there differences in the artifact assemblages from different troops (e.g., Tenth Calvary vs. Twenty-fourth Infantry, or Ninth vs. Tenth Calvary)? If so, what were they, and what factors affected the processes of acquisition, use, discard, and reuse? How would these compare to South's (1977) frontier artifact pattern for military and outpost sites? Likewise, how much of what was found is a reflection of the individual, or group of individuals (e.g. officers vs. enlisted men), and how much did military standards and regulations govern these processes? If military decisions and regulations-beginning with the initial acquisition from military supplies, to what was issued to whom, to what and how they were used, and finally to how they were discarded or abandoned - were determining factors, it should be evident in the archaeological record.

\section{The Buffalo Soldiers}

Another research issue included the specific evidence for the occupation and use of Camp Elizabeth by the Buffalo Soldiers. There may be contextual evidence for ethnically distinct behavior through analysis of the cultural material. Historical archaeologists have taken three broad approaches to examining AfricanAmerican sites and deposits: socioeconomic studies, subsistence studies, and settlement type/spatial analysis of material remains (Bousman et al. 1995:11). Often the studies include contrasting data that attempt to measure the economic power of African-Americans relative to the European-American population (Bousman et al. 1995:12). Most of this work has been conducted on nonmilitary, plantation and urban sites. Majewski and O'Brien (1987) report that a number of archaeologist have used ceramic remains for determining relative socioeconomic status, ethnicity, and occupation (e.g., Cheek et al. 1983; Felton and Schulz 1983; Henry 1987; Henry and Garrow 1982; Henry et al. 1983; Klein and Garrow 1982; Saunders 1982; Schuyler 1980; Spencer-Wood 1987); however, interpretation has been greatly limited by the inability of archaeologists to clearly separate ethnicity from socioeconomic choices and position (Bousman et al.
1995:11-12). One suggested indicator for determining ethnicity in African-American historic sites, predicated on the assumption that food practices have traditionally varied among ethnic groups and that differences in food preparation and serving items are reflected in the archaeological remains, is ethnic differences in preferred vessel form (Baker 1980; Deetz 1977; Otto 1984, in Bousman et al. 1995:12). Several plantation site studies have compared hollow ware vs. flat ware and concluded that African-American slaves consumed greater quantities of slow-simmer foods (i.e. soups and stews) prepared and served in hollow ware vessels (Baker 1978, 1980 ; Otto 1975, 1977, 1984). However, these factors may also be affected by socioeconomic conditions of slavery and not choice.

Bousman et al (1995:12) suggest that consumer choice studies have attempted to explain why goods of differing quality and/or price were selected by individuals and households for acquisition and archaeological deposition. Further, consumer-choice researchers argue that social class and ethnic group membership greatly affect the access to goods and the distribution of goods (Adams 1966; Fried 1967; Hodder and Orton 1979; Rathje 1971; Sabloff and Rathje 1975; and Spencer-Wood 1987). One issue related to the possible occupation of Camp Elizabeth by African-American soldiers is were there differences in not the acquisition of materials, but the distribution of materials? Were military supplies distributed equally in terms of quality and quantity among the various troops, and specifically among the black troops, and is it possible to discern this in the archaeological record? Of course, this evidence would have to be corroborated with military supply lists and pertinent archival sources.

Many plantation site researchers studying the relationship between diet and socioeconomic status and ethnicity have proposed that foodways often served as a mechanism for maintaining ethnic identity (Ascher and Fairbanks 1971; Drucker 1981; Miller 1979; Otto 1977; 1984; Reitz 1994). However, there has been little subsistence and ethnicity research on non-plantation sites (Bousman et al. 1995:14). A study of 1880-1940 African-American urban alley households in Washington, D.C., by Cheek and Friedlander (1990) yielded evidence for the 
consumption of pig's feet, opossum, and greens, reflecting the rural background of the inhabitants (Bousman et al. 1995:14).

Settlement archaeology is the study of past social relationships expressed in physical terms (Orser 1988:82). Most settlement pattern research concerned with African-American occupations has also been on plantation and urban sites. However, not much evidence for ethnicity has been discovered due to other non-ethnic and noneconomic factors such as defense considerations, ecological decisions (proximity to springs), and intended duration of occupation, as suggested by Kelso (1984) in his examination of Kingsmill Plantation. Likewise, most spatial analyses of African-American urban sites consider the urban determinants over ethnicity for understanding activity areas, land use, and artifact distributions (Bousman et al. 1995:13-14). 


\section{Chapter 4: Archival Investigations}

\section{José E. Zapata, I. Waynne Cox, and C. Britt Bousman}

\section{Archival Methods}

For the archival study, we reviewed published and primary sources. During these investigations, materials from the Fort Concho Library and Archives in San Angelo, the Texas State Library and Archives in Austin, and the Ft. Worth regional office of the National Archives were inspected.

Over a dozen reels of microfilm from the National Archives and the Fort Concho Archives were examined over a six-month period. These included, but were not limited to, the Monthly Returns from U.S. Military Posts, 1800-1916; Historical Information Pertaining to Military Posts and Other Installations, ca. 1700-1900; The Negro in the Military Service of the United States, 1639-1886; and Register of Enlistments, 1798-1914. Research at the Texas State Library and Archives was completed over a two-week period. Material pertaining to the Texas Rangers, as well as on early frontier posts, was examined. This included the Military Organization Records, ca. 18361881; Quarter Master Records, Returns and Requisitions; General Orders Ledger, 1870-1897; Frontier Forces Correspondence, 1870; and the Monthly Returns, 1874-1877. In addition to these primary sources, we consulted more than 35 books, journals, and reports.

We were able to extract pertinent information from published sources such as Carroll (1971), Cashin (1993), Fehrenbach (1968), Foner (1974), Fowler (1971), Fox (1983), Santleben (1994), Schubert (1995, 1997), and Utley (1967, 1973). These publications provided valuable insight into the state's history and development, military posts, state and federal military detachments, and the history of the Texas Rangers; as well as the history of Ft. Chadbourne, Ft. Concho, Camp Elizabeth, and of the Buffalo Soldiers. These sources have been used to elaborate our discussion of specific personalities, places, and events. Especially useful in this regard were oral histories and biographical sketches provided in On the Border with MacKenzie (Carter 1961 [1935]), General MacKenzie and Fort Concho (Crimmins 1934), Fort Concho and the Texas Frontier (Haley 1952), and A Texas Pioneer: Early Staging and Overland Freighting Days on the Frontiers of Texas and Mexico (Santleben 1994 [1910]).

Using the bibliographies and footnotes of the published sources as a guide, we were then able to selectively reference the primary material (e.g., state and Federal Military Organization Records, Monthly Returns from U.S. Military Posts, State Quarter Master Records, and U.S. Census Records). The intent was to pursue information relating to our specific research goals, especially that which may have been only marginally developed in previous research.

After developing a general understanding of the study area, we gathered data on the history of early frontier defense, early settlements, and military posts. We then focused on more specific and detailed data relating to places, events, and personalities. These efforts generated an enormous amount of information which was entered into an Excel spreadsheet. This allowed us to sort specific information, cross-reference data, and retrieve an assortment of category-defined files. Over one thousand unduplicated records were compiled from the primary and published sources. In addition, the 1870 and 1880 U.S. Census returns for Ft. Concho, San Angelo, Texas, were entered into an Excel spreadsheet (Appendix A).

\section{Archival Results}

In developing a historical synthesis of Camp Elizabeth, the site and study area were considered within a broader context: the settling and defense of the Western Frontier. Chief among these considerations was the state's emergence as a viable entity. That is, the development 
of its infrastructures (communication, roads, and railways), settling of the frontier (primarily through ranching and farming), and the military's response to public safety (protection of its citizenry and their property).

Adding to the complexity of this mission was the state's immense size and the fact that the area west of the 98th meridian, the Western Frontier, was the domain of the Plains Indians (Figure 4-1). The efforts of the state and federal governments notwithstanding, the frontier's unsettled condition persisted for almost half a century after it was included within the boundaries of Texas (ca. 1835-1880).

The fact that the Native American fought fiercely to maintain sovereignty of the Western Frontier was owing in large part to the area's buffalo population. Over the course of several centuries, the buffalo was the Native Americans' primary means of subsistence, providing food and raw materials for producing much of their technology (i.e., clothing, shelter, and tools). The Euro-American's desire to push westward and

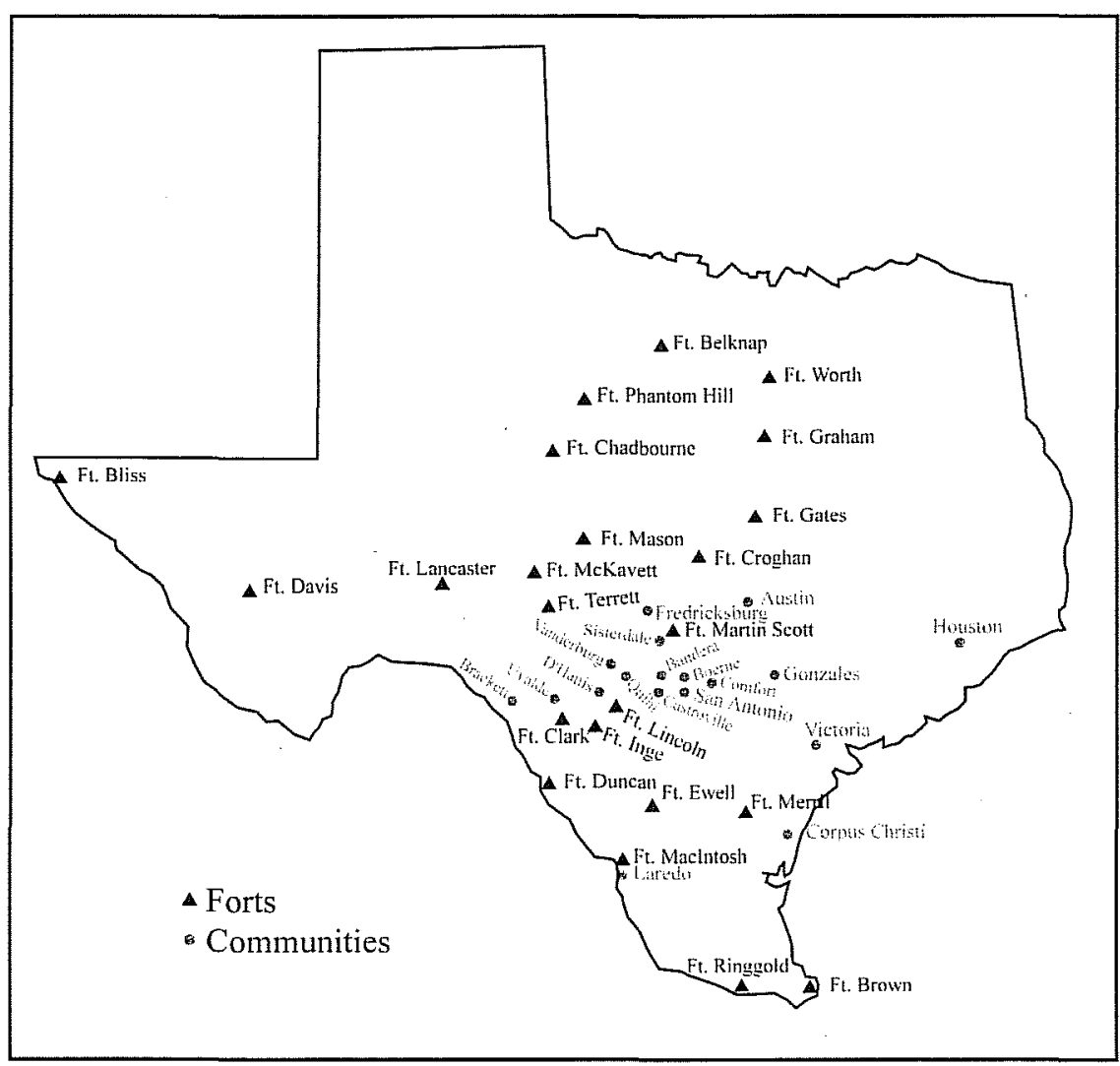

Figure 4-1. Texas forts and selected communities in 1855. Adapted from Fox (1983:240). the Native Americans' urgency to maintain their livelihood laid the foundation for a hard-fought and drawn-out conflict.

\section{The Republic of Texas, 1836-1845}

The frontier's precarious position was addressed immediately after Texas declared its independence from Mexico. Intermittently, between 1836 and 1845 , the Texas Mounted Volunteers and Gunmen afforded the only frontier protection (Fehrenbach 1968; Webb 1965). Prior to that, volunteer ranging companies had been formed ca. 1923 (Fehrenbach 1968). Lt. Moses Morrison led a command of 10 men to protect Austin's colony on the lower Colorado and Brazos rivers in 1923 (Kilgore 1973). Adding to the area's instability was President Monroe's policy of 1825 which created a line of fortification along the 95th meridian and effectively forced the eastern tribes to the west of the boundary (Bell et al. 1980). By 1826, the official record of Austin's colony makes note of the need to keep a permanent force of between 20 and 30 Rangers in service (Webb 1965).

During the Republic of Texas era (1836-1845), a number of legislative directives addressed the need for frontier defense. The earliest of these was set forth by Daniel Parker, a member of the "permanent council" of the Texas Revolution. On October 17, 1835, Parker moved to create a corps of Rangers to protect the frontier between the Brazos and Trinity rivers. Parker's motion was amended to include the area between the Colorado and Guadalupe rivers. The final ordinance established a corps of Texas Rangers, comprised of three companies of 56 men. On November $28,1835, R$. M. Williamson was elected major, with I. W. Burton, W. H. Arrington, and 
J. J. Tumlinson serving as captains (Kilgore 1973; Webb 1965).

The concept of using "ranging companies" was not a new one to Euro-American settlers, and the practice persisted intermittently in Texas for almost 50 years (ca.1823-1870). Such ranging companies, at times simply referred to as mounted gunmen or riflemen, were raised in response to real or perceived threats by indigenous tribes. The men were often ill-equipped and minimally compensated for their service, but they were, nevertheless, an efficient and formidable force (Fehrenbach 1968; Kilgore 1973; Webb 1965). Between 1836 and 1845, the Republic of Texas established no less than 10 frontier forts. Four of these forts were established fairly early: Ft. Milam, 1834; Ft. Colorado, 1836; Ft. Houston, 1836; and Ft. Lyday, 1836. These early forts were established explicitly for frontier defense and garrisoned by the Texas Rangers (Tyler 1996).

When Samuel Houston assumed the Republic of Texas presidency in 1842, he and the 6th Texas Congress turned off the public tap. In a series of acts, dozens of public offices were abolished and the army was reduced to a few companies of Rangers (Fehrenbach 1968). After 1845, a combination of state volunteer regiments and federal military forces was used for frontier defense. However, Fehrenbach (1968:276) notes that no state had ever come into the Union with more than half its territory unsettled. The biggest problem facing western expansion and settlement of the Western Frontier was that the area was virtually uncharted and would remain so well into the mid1870s.

\section{Statehood to the Confederacy, 1846-1865}

What will become obvious in the following discussion is that the area between San Antonio and El Paso was largely uncharted, unsettled, and extremely dangerous to traverse. Although San Antonio and El Paso originated from seventeenth-century Spanish colonial presidios (military posts), a direct route between these two towns was not pursued until fairly late. In 1848 and 1849 , the people of Texas were intent to show the rest of the country that they possessed a practical route for a railroad from east to west, and from that point to the coast of California (Ford 1987). The distance between San Antonio and El Paso was about 600 miles, and the territory was practically unknown. One of the first formal attempts to establish such a route was made by Col. John C. Hays. Assuming control of an expedition bound for El Paso, he instead struck the Rio Grande some distance below El Paso, failing to accomplish the objective (Ford 1987). In 1849, further induced by the discovery of gold in California, public meetings were held at the state capitol. The purpose of these was to ascertain whether a practical route could be established between Austin and El Paso. It was then decided to send two parties to El Paso: Major Robert S. Neighbors and John S. Ford took the upper route, while Lt. W. H. C. Whiting took the lower. After both parties reported back, it was decided that the upper route was more practical (Ford 1987).

\section{Early Routes and Settlements}

By the 1850s, the San Antonio to El Paso road carried an ever-increasing number of emigrants, freight, and mail. The transcontinental trail meandered westward from San Antonio to Ft. Inge, Ft. Clark, Camp Hudson, Ft. Lancaster, Ft. Stockton, Ft. Davis, Ft. Quitman, and on to El Paso. From El Paso, the trail then took a fairly direct route, moving west-northwest along the international border toward San Francisco (Utley 1967). With the exception of Ft. Inge, established in 1849 , the other military posts along the Texas route were intermittently located to afford protection.

One of the better accounts of the untamed conditions that plagued the western frontier around 1850 is offered by Santleben (1994). He recounts the early (pre-1860) settlements and specific settlers along the San Antonio to El Paso road. Among the settlements listed by Santleben (1994:244-249) were Castroville (1844), Quihi (1846), Vanderburg (1847), D'Hanis (1847), Lytle Ranch (1850), Adams Ranch (1850), Ft. Lincoln (1850), Uvalde (1850), Brackett (1852), and Ft. Clark (1856). The westernmost settlements were Uvalde, located some 40 miles west of Castroville, and Ft. Clark, about 50 miles west of Uvalde. 
As detailed by Santleben (1994:250-255), the area west/northwest of San Antonio, and off the road to El Paso, was also only marginally populated in the 1850 s. There was Fredericksburg (1846), Sisterdale (1847), Bandera (1850), Boerne (1851), Comfort (1851), and Hedwig's Hill (mid-1850s). Figure 4-1 illustrates how remote the Western Frontier area was ca. 1850. The early settlers suffered innumerable depredations-loss of family, friends, and property-but somehow managed to maintain their resolve. Many of these settlements were within a half-day's ride from each other and afforded each other protection or sanctuary in times of need.

\section{The Texas Rangers}

The state's response to frontier protection was afforded through the efforts of the Rangers; a term which referred to Indian fighters, the kind of men who carried war to the enemy (Fehrenbach 1968). For 50 years after the time of Lt. Moses Morrison's company, the Rangers existed only intermittently as volunteers, organized for brief periods to respond to real or threatened attacks by Indians and later the Mexicans (Kilgore 1973). Ranger companies guarding the frontier had more or less permanent duty because the danger never ceased. Yet, there were never sufficient funds to pay or equip them for any extended period (Fehrenbach 1968).

The ranging companies evolved slowly but in strikingly adaptive ways. During most of the nineteenth century, they were one of the most colorful, efficient, and deadly band of irregular partisans; their best defense was to attack, dominate, and subdue. The U.S. Army disliked the Ranger operations, and the Rangers grew to hold the Army in increasing contempt. Fueling such sentiments were the differing strategies pursued by these two forces: the Army tried to police the frontier while the Rangers rode to punish the Indians (Fehrenbach 1968).

In 1846, Colonel John C. "Jack" Hays assumed command of the second regiment of Texas Rangers. The first act of Colonel Hays in assuming command of the northern and western frontier of Texas was to establish a line just above the edge of the outer tier of settlements. The Ranger commanders were instructed to send patrols between their respective stations and give protection to life and property (Ford 1987). Most of these efforts were focused in North Texas in the Panhandle region.

The Rangers were not totally neglectful of the western frontier. Three separate invoices, indicating a Ranger presence in the study area, were located. One of these was from E. Krauskopf of Fredericksburg, for repair of assorted firearms, listing 28 unduplicated names. This invoice noted the work was done for Captain Rodgers's Company of Mounted Rangers in November 1854, and was signed by Lt. A. S. Wright (Texas State Library and Archives [TSA], Record Group [RG] 401:1153.21). Another invoice for supplies dated December 1,1854 , indicates that two companies of Mounted Volunteers were operating within the study area. The Johnson's Station invoice, signed by Captain Rodgers was for $1871 / 2$ bushels of corn, "complete forage for 170 horses for five days" (TSA RG 401:1153.22). Another originated from San Antonio and was dated December 23, 1854. This was the invoice of provisions for Captain P. H. Rodgers's Company "F" Texas Mounted Volunteers for nine days, commencing on the 15 th and ending on the $23 \mathrm{rd}$ of December 1854. This last invoice noted a complement of three officers and 76 men (TSA RG 401:1153.23).

\section{The U.S. Army's First Line of Defense}

With the annexation of Texas came the awesome responsibility of providing for frontier defense, and in the 1840s and 1850s, neither the War Department nor the U.S. Army had much understanding of the Plains Indian frontier (Fehrenbach 1968). Santleben (1994) argues that the federal response was inefficient and illustrates this by pointing out the ineffectiveness of the Dragoons on their large, heavy, Missouri-raised horses. These mounts were much too slow and clumsy when in pursuit of the small, hardy, and active native animals. The U.S. Army kept only a few thousand soldiers in the state which was no defense against the wide-ranging Comanches. 
Immediately after the war with Mexico, the United States established the 8th Military Department under the command of Brevet Major General George Mercer Brooke. He then proceeded to establish a series of thirteen forts in Texas. Eight of these were strategically located in West Texas (Table 4-1), and the remaining five were located in southwest Texas: Ft. Brown, 1846 (7th Infantry); Ft. Ringgold, 1848 (1st Infantry); Ft. Bliss, 1848 (3rd Infantry); Ft. McIntosh, 1850 (1st Infantry); and Ft. Merrill, 1850 (1st Infantry). The western forts followed a meandering line that outlined the ca. 1849 limits of settlements (Figure 4-1, Table 4-1). The future site of one of these, Ft. Croghan, was initially occupied by a company of Henry E. McCulloch's Rangers (Tyler 1996).

Table 4-1. Early Texas Forts:

First Line of Frontier Defense, from North to South

\begin{tabular}{lcll}
\multicolumn{1}{c}{$\begin{array}{c}\text { Military } \\
\text { Post }\end{array}$} & $\begin{array}{c}\text { Occu pation } \\
\text { Dates }\end{array}$ & \multicolumn{1}{c}{$\begin{array}{c}\text { Nearest } \\
\text { Town* }\end{array}$} & \multicolumn{1}{c}{$\begin{array}{c}\text { Original } \\
\text { Detachment }\end{array}$} \\
\hline Ft. Worth & $1849-1853$ & Ft. Worth & 2nd Dragoons \\
Ft. Graham & $1848-1853$ & Hillsboro & 2nd Dragoons \\
Ft. Gates & $1849-1852$ & Gatesville & 8th Infantry \\
Ft. Croghan & $1849-1855$ & Burnett & 2nd Dragoons \\
Ft. Martin Scott & $1848-1866$ & Fredericksburg & 1st Infantry \\
Ft. Lincoln & $1849-1852$ & D'Hanis & 8th Infantry \\
Ft. Inge & $1849-1869$ & Uvalde & 1st Infantry \\
Ft. Duncan & $1849-1920$ & Eagle Pass & 1st Infantry \\
\hline
\end{tabular}

*Nearest town is used as a reference point, and may not be contemporary with the military post.

The earliest military post established within the Camp Elizabeth study area was Camp Chadbourne. The Post Return for "Camp Chadbourne near Fredericksburg" (April 1849) notes that it was under the command of Brevet Lieutenant Colonel W. R. Montgomery, 8th Infantry. The camp was garrisoned by Companies $\mathrm{D}$, F, I, and $\mathrm{K}$ of the 8th Infantry. The command was comprised of seven officers, including an Assistant Surgeon, 14 non-commissioned officers, three drummers, three fifers, and 55 privates (National Archives [NA] Record Group [RG] 617:195).
The preceding citation was taken from a National Archives microfilm and was limited to one entry, the Post Return for April 1849. The next record on this same microfilm is the October 1852 Post Return for Ft. Chadbourne; indicating a 3.5-year gap. We had initially thought that Camp Chadbourne and Ft. Chadbourne were one in the same, but this was not the case. Several of the published sources were examined, but none listed Camp Chadbourne (e.g., Fox 1983; Fehrenbach 1968; Santleben 1994; Tyler 1996; Utley 1967). Our conclusion is that Camp Chadbourne (ca.1849-1852) was succeeded by Camp Johnston (elaborated below).

\section{U.S. Army's Second Line of Defense}

Within a couple of years after its establishment, the Army's "Indian Frontier Line" had become obsolete. Between 1845 and 1850 , the number of settlers in Texas grew from 135,000 to more than 212,000 (Fox 1983:260). Many of these Army posts were logistically out-paced by the increasing western settlements, and additional posts were added. The initial line of defense ran southwesterly, between the 96 th and 100th meridians, while the second line of defense, consisting of seven additional forts (Figure 4-2, Table 4-2), formed an arching pattern to the west-northwest of the first line, and toward the study area.

The Army's second effort resulted in the establishment of Ft. Chadbourne, well within the Camp Elizabeth study area. The establishment of this fort was preceded by Camp Johnston or Camp J. E. Johnson - the Army's records are unclear as to the exact name ("Historical Information Relating to Military Posts and Other Installations, ca. 1700-1900," NA RG 661:1-8). To avoid confusion with Johnson's Station, located southeast of Ft. Concho, we have elected to use the name Johnston.

Camp Johnston was established March 15, 1852, on the south side of the North Concho River at latitude $31^{\circ} 30^{\prime}$ and longitude $100^{\circ} 51^{\prime}$ by Companies A, C, I, 


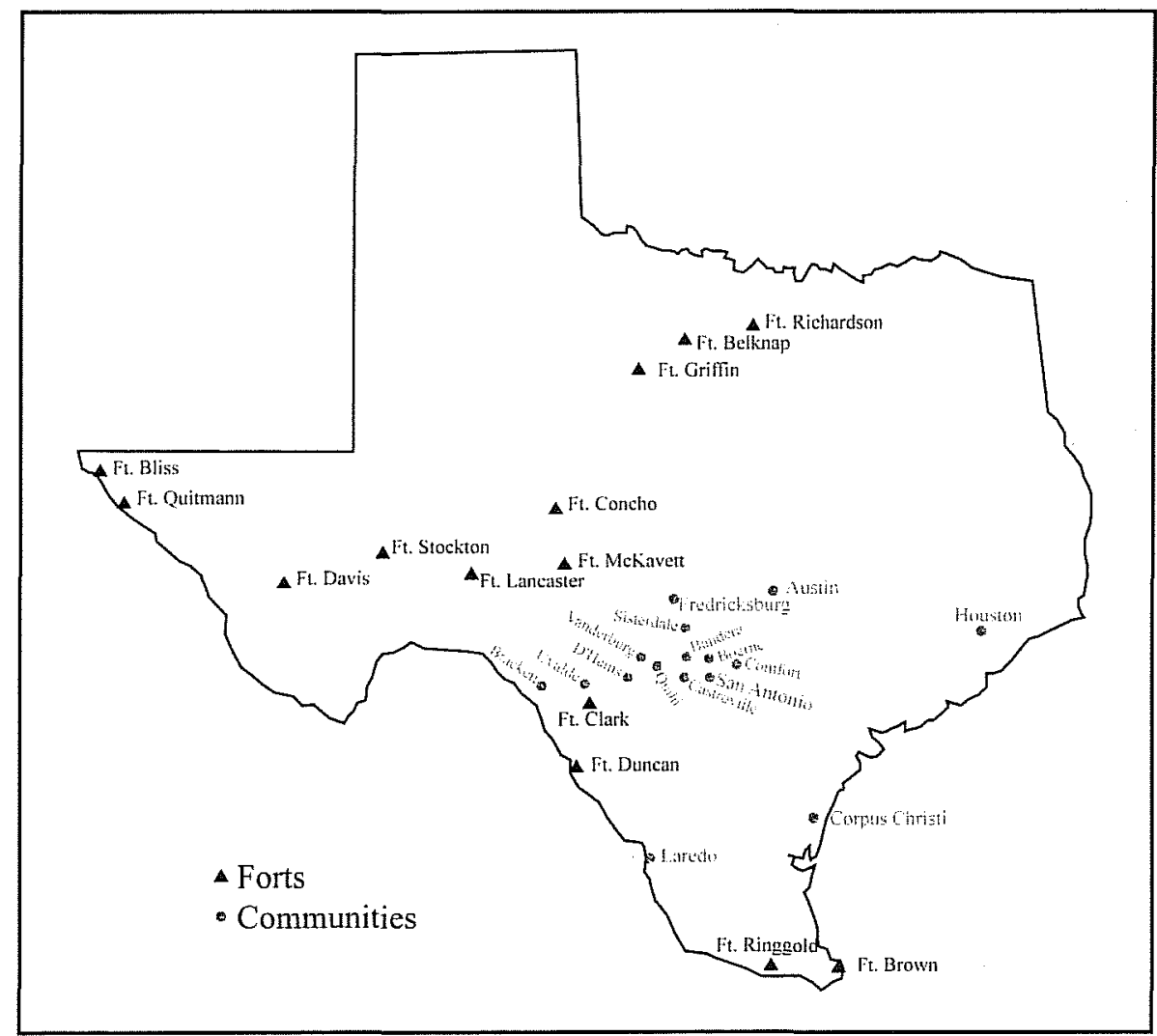

Figure 4-2. Texas forts and selected communities in 1870. Adapted from Fox $(1983: 240)$

Table 4-2. Early Texas Forts: Second Line of Frontier Defense, from North to South

\begin{tabular}{llll}
\multicolumn{1}{c}{$\begin{array}{c}\text { Military } \\
\text { Post }\end{array}$} & $\begin{array}{c}\text { Occupation } \\
\text { Dates }\end{array}$ & \multicolumn{1}{c}{$\begin{array}{c}\text { Nearest } \\
\text { Town* }\end{array}$} & \multicolumn{1}{c}{$\begin{array}{c}\text { Original } \\
\text { Detachment }\end{array}$} \\
\hline Ft. Belknap & $1851-1867$ & Newcastle & 5th Inf antry and 2nd Dra goons \\
Ft. Phantom Hill & $1851-1854$ & Anson & 5th Infantry \\
Ft. Chadbourne & $1852-1867$ & Bronte & 8th Infantry \\
Ft. Mason & $1851-1869$ & Mason & 2nd Dragoons \\
Ft. McKavett & $1852-1883$ & Menard & Several Infantry Regiments \\
Ft. Terrett & $1852-1854$ & Roosevelt & Unavailable \\
Ft. Clark & $1852-1944$ & Brackettville & 1st Infantry \\
\hline
\end{tabular}

* Nearest town used as a reference point, and may not be contemporary with the military post. 
and $\mathrm{K}, 8$ th Infantry (NA RG 661:4.307). Although not stipulated in the records, it seems plausible that the garrison at Camp Chadbourne was relocated to Camp Johnston. There is a three-year break between the only entry for Camp Chadbourne (April 1849) and the establishment of Camp Johnston (March 1852). Problematic as it may seem, we propose that the 8th Infantry relocated to the Johnston site for logistical reasons and/or for lack of adequate foraging. A comparison of the regiment, companies, and officers assigned to these camps indicates a small degree of continuity. For example, both were garrisoned by the 8th Infantry, and two of the five companies (Co. I and $\mathrm{Co} . \mathrm{K}$ ) mentioned in the reports were assigned to both locations. In addition, Brevet Lieutenant Colonel W. R. Montgomery, 1st Lieutenant Snelling, and 2nd Lieutenant Haldeman, appear on both returns-Camp Chadbourne, April 1849 and Camp Johnston, October 1852 and November 1852. However, we did note that the latter report listed Montgomery and Haldeman as being on detached duty, since July 1850 and January 1852, respectively (NA RG 617:195).

\section{Ft. Chadbourne (Pre-Civil War)}

On October 21, 1852, Companies A and K, 8th Infantry, left Camp Johnston to establish a post on Oak Creek, a tributary of the Colorado River, 30 miles from its mouth. The post was to be called Ft. Chadbourne (NA RG 617:195). The following month, November 1852, Camp Johnston was abandoned and the rest of the garrison transferred to Ft. Chadbourne (NA RG 661:4.307). The November 1852 Post Return for Ft. Chadbourne notes that Captain Arthur T. Lee of the 8th Infantry was in command of Companies A, $\mathrm{C}, \mathrm{G}, \mathrm{I}$, and $\mathrm{K}$. The official complement was 10 officers, including an Assistant Surgeon, 23 noncommissioned officers, three buglers, and 88 privates. This included two civilians: Samuel Cherry, Guide, and John Taylor, Indian Interpreter. Captain Lee noted that "Companies C, G, and I of the command joined at Ft. Chadbourne, Texas after leaving Camp Johnston on the North Concho. Companies $\mathrm{A}$ and $\mathrm{K}$ having preceded them and established the post" (NA RG 617:195).
In January 1853 , Ft. Chadbourne was under the command of Brevet Brigadier General John Garland, 8th Infantry. His command was comprised of Companies A, C, G, I, and $\mathrm{K}$ with a complement of seven officers, including an Assistant Surgeon, 18 noncommissioned officers, two buglers, three musicians, and 55 privates ("For Duty," NA RG 617:195). Wooster (1987) made a point of the fact that the fort was not at full strength during March 1853. At that time Ft. Chadbourne listed five companies of the 8th Infantry, comprised of 15 officers and 225 enlisted men. Of these, 89 were on detached duty, 19 were under arrest, seven were ill, and 43 were on extra duty. This left three officers and 79 enlisted men ready for action.

By October 1853, the post was down to two officers and 67 enlisted men of the 8th Infantry. At this time, the command was turned over to 1 st Lieutenant I. M. Hawes of the 2nd Dragoons. Only two companies were present: Company C, 2nd Dragoons, and Company A, 8th Infantry. The 2 nd Dragoons joined the post by transfer from Ft. Graham on October 22, 1853 (NA RG 617:195). On December 22, 1853, the strength of the post was further diminished with the transfer of Company A, 8th Infantry, to Ringgold Barracks in Rio Grande City (NA RG 617:195). A minimal force of 2nd Dragoons remained at this post through August 1855 , when they were replaced by two companies of the 1 st Infantry from Ft. Duncan, with a total complement of an Assistant Surgeon, four officers, 11 non-commissioned officers, two musicians, and 54 privates commanded by Captain L. Eastman. Companies C and F, 2nd Dragoons, left for Ft. Riley, Kansas, on August 18, 1855 (NA RG 617:195). Also in 1855, the 2nd Dragoons were redesignated the 2nd Cavalry (Utley 1967).

In terms of specific activities of the troops at $\mathrm{Ft}$. Chadbourne, we were unsuccessful in locating any detailed accounts. Generally, notes that make reference to scouts, mail or cattle drive escorts, and Indian sightings and/or skirmishes can be located within a particular post's Monthly Return. In the case of Ft. Chadbourne, the only items of note were references to the post's construction activities or repairs. Between April and July 1854, the post had a master carpenter and a master stone mason under its employ (NA RG 
617:195). In June 1857, Captain John H. King, 1st Infantry, Company I, was listed as being on detached service: "purchasing lumber at Guadalupe River" (NA RG 617:195). At various times between November 1852 and August 1854, the post also employed a guide and an interpreter. This indicates some scouting activities, such as that suggested by a February 1855 entry, indicating that Company F, 2nd Dragoons, was "detached in the field" (NA RG 617:195).

By the mid-1850s, the Army had established two lines of posts to respond to any eminent threat to frontier settlement and a third line of posts guarding the international border with Mexico (Utley 1967). Between 1854 and 1858, an additional four posts were added and located to defend the San Antonio to El Paso road: Ft. Davis, 1854-1891 (8th Infantry); Ft. Lancaster, 1855-1883 (1st Infantry); Ft. Quitman, 1858 (8th Infantry); and Ft. Stockton, 1859 (8th Infantry).

\section{Assuming the Offensive}

As of the late 1850 s, the Army had established 22 forts in Texas, 15 of which were still active, including four of the five located in far-West Texas and South Texas. The outer posts were meant to be garrisoned by infantry regiments and the inner posts by cavalry regiments (Utley 1967). Ft. Chadboume lay within the inner cordon, and was alternately or jointly garrisoned by the 2 nd Dragoons/Infantry and 1st Infantry. By the late 1850 s, the Army had effectively quelled the Indian depredations in the frontier. One of the major offensive maneuvers of this late date was headed by Brevet Major Earl Van Dorn, 2nd Cavalry, of Ft. Chadbourne. Before this, however, the Rangers, under the command of Captain "Rip" Ford demonstrated the possibility of success (Fehrenbach 1974:428-438; Webb 1965:151-161).

The 2nd Cavalry (formerly the Dragoons) were garrisoned at Ft. Chadbourne again briefly in August and September 1858. On August 9, 1858, Major Van Dorn was ordered to "report in person at San Antonio for further orders relative to proposed scout against Indians" (NA RG 617:195). On September 5, 1858, Companies A and G, of the 2nd Cavalry (two officers and 68 enlisted men) left Ft. Chadbourne on assignment to the "Wichita Expedition." This was a punitive expedition against the Comanches of North Texas, and was led by Major Van Dorn. The combined offensive efforts of the Rangers and 2nd Cavalry subdued the Indians in Texas by the late 1850 s, but the Civil War undermined this success (Fehrenbach 1974). According to Utley (1967:141), these punitive campaigns only served to give rise to a "Plains Indian barrier that for a quarter of a century slowed the advance of the American frontier."

\section{The Civil War Years}

In February 1861, Ft. Chadbourne was under the command of Lieutenant Colonel Morris, 1st Infantry. His command was comprised of three companies of the 1st Infantry consisting of four officers and 63 enlisted men (NA RG 617:195). When Texas seceded from the Union, the U.S. forces peacefully abandoned the state's forts, and the frontier was left to the defense of minute companies and the Texas Rangers who occupied the posts in small detachments. Pursuant to General Order No. 8, dated February 28, 1861, Ft. Chadbourne was surrendered to Col. Henry E. McCulloch of the Confederate States of America (NA RG 617:195).

Indian depredations along the western frontier did not increase during this period (Santleben 1994), but the northern counties faired poorly (Fehrenbach 1974). This was largely due to the fact that the western frontier remained sparsely settled, while the northern region of the state had enjoyed some prosperous years, and the area's abundant livestock proved to be more inviting to raiding parties. Especially ravaged and depopulated during this period were Clay, Cooke, Denton, Jack, Montague, Palo Pinto, Parker, Young, and Wise counties in north Texas (Fehrenbach 1974:452-453).

In discussing the conditions along the western frontier, Santleben (1994:259-260) asserts that the Indians made very few forays into this region during the Civil War period. The security of the frontier was insured by a cavalry regiment raised in 1861 by the Texas government. The companies were stationed in 
intervals along the outskirts of the settlements in the country between the Rio Grande and the Red River. This regiment was retained in that service through 1864, under the auspices of the state during its first year and then under the Confederate government.

Ft. Chadbourne may have served as a station for the aforementioned frontier cavalry, but its use by these frontier forces may have been brief. On March 22, 1861 , Ft. Chadbourne's inventory of clothing, camp equipment, and garrison equipage was turned over to Lieutenant I. L. King, Quarter Master of Captain Moore's company of Mounted Rangers, by Lieutenant G. H. Leigh, Assistant Quarter Master (TSA RG 401:836.24 and 1155.21). The post was abandoned by the 1 st U.S. Infantry on the following day (NA RG 661:2). During the months of March, April, and May 1861 , the post's inventory was portioned out to Ranger Captain A. B. Burleson, to the troops at Ft. Chadbourne under the command of Lieutenant I. G. Davidson, and to Ranger Captain R. B. Haley (TSA RG401: 836.24-25).

It is unclear how many men were posted at Ft. Chadbourne during the Civil War period because only a handful of documents relating to this post have survived. Cited above were records for March, April, and May 1861. Records covering the remainder of the Civil War period were either lost or, very possibly, never existed. A few other records that place the Rangers in the Camp Elizabeth study area were located. Among these is a March 1861 invoice for "1200 rations at .25 cents each," (40-day rations for 30 men), generated by Captain Ewen Cameron of the Texas Rangers in Fredericksburg (TSA RG 401:1155.23). Another invoice dated April 1861 places Captain A. B. Burleson of the Texas Rangers at Home Creek, in western Coleman County (TSA RG 401:839.21). Another invoice, dated May 1861, was found for Captain Davidson's Company G, Texas Mounted Rifles (TSA RG 401:836.25). Although the source and location for this latter invoice was undisclosed, Captain Davidson may be the Lieutenant Davidson mentioned as being in command of Ft. Chadbourne during April 1861 (TSA RG401: 836.24-25).
Adding to the fragmentary notations of Ranger activity in the study area are four notes on requisitions for the 1 st Regiment, Texas Mounted Rifleman at Camp Concha [sic], dated July 14, July 26, July 29, 1861, and September 1861 (TSA RG 401:835.6). The name "Concha" may be a misprint of Concho, and, if so, this would place the Texas Mounted Rifleman in the study area. Unfortunately, the information provided was extremely abbreviated and impossible to pursue. One last requisition for supplies that serves to locate frontier forces in the study area was located. This was a requisition submitted by $M$. F. Loeke, commanding the 3rd Regiment of Texas Cavalry, listing subsistence for "Horses and Mules (979 horse) in the service of the state for the day commencing 4 October and ending 13 October 1861, Camp Big Spring" (TSA RG 401:841.15).

The state's Western Frontier was settled slowly over a period of some 20 years (1846-1865). At the start of the Civil War, the U.S. Army had about 2,700 federal troops deployed throughout Texas (Fehrenbach 1974). Of the 20 forts established at or west of the "Indian Frontier Line," 15 remained active at the start of the Civil War. The San Antonio to El Paso road, with the addition of strategically placed forts, had become somewhat safer to travel, but the fact that the vast Western Frontier remained uncharted may have slowed the development of settlements. Adding to this problem were continued raids on the few settlements that did exist and on westbound travelers by Indians. These were the prevailing conditions along the Western Frontier prior to the Civil War. With the removal of the U.S. forces from Texas Indian raiding did not increase. Owing in large part to the state's Confederate government effecting peace and alliances with the Northern tribes (Fehrenbach 1974) and increased policing of the area by Texas Rangers (Santleben 1994), conditions along the Western Frontier were fairly stable throughout the Civil War period.

\section{Reconstruction to the Final Years, 1866-1885}

The post-war years were marked by the Reconstruction period (1865-1874), during which the initial priority of the military was to restore a loyal government. By 
May 1865 , there were close to 51,000 federal troops deployed throughout Texas. The South was divided into five military districts under the command of the army, and the existing governments were considered provisional. By 1866, the U.S. government demobilized its military, leaving only about 3,000 troops in the state, with most of these posted along the frontier (Tyler 1996). Fifteen pre-Civil War forts were reoccupied by the army between 1866 and 1867 , and three additional forts were established: Ft. Buffalo Springs/Richardson, Ft. Concho, and Ft. Griffin (Table 4-3).

\section{Reoccupation of Fort Chadbourne}

The nearest post to the Camp Elizabeth study area was not reoccupied by the army until two years after the end of the Civil War. Pursuant to Special Order No. 13 , Company $\mathrm{G}$ of the 4th Cavalry arrived at Ft. Chadbourne from Ft. Mason on May 25, 1867. By the following month, with Captain E. B. Beaumont in command, the post had three additional companies of the 4th Cavalry present: Companies A, D, G, and M with a total complement of four officers and 143 enlisted men (NA RG 617:195). The post must have been in a serious state of disrepair when it was reoccupied in May 1867 because by August there were no less than 103 construction workers employed. The "citizens employed" by the post included a superintendent of mechanics, two engineers, two sawyers, a stone mason foreman, 41 stone masons, 42 carpenters, eight quarrymen, four blacksmiths, a wheelwright, and a lime burner (NA RG 617:195).
While the post was undergoing repairs, a letter dated July 31 was received on August 15 from the Department of Texas Headquarters. The letter directed the Ft. Chadbourne commander to undertake a careful examination of the nearby country, with a view to changing the post (NA RG 617:195). Evidently the site of the fort had already proven to be unfavorable, yet the repairs to the post continued for the next three months; the post return for the month of November 1867 lists about the same number of construction workers. On November 5, one officer, two noncommissioned officers and 15 privates left the post to meet with a "Board of Officers" who were searching for a permanent location for the new post (NA RG 617:195). Within a matter of three weeks (November 27), a detachment of Company $\mathrm{H}$, 4th Cavalry (one officer and 58 enlisted men), marched to the new post at the fork of the two Conchos about 100 miles northwest of Ft. Mason, "there to be stationed permanently" (NA RG 617:195).

The monthly returns for Ft. Chadbourne (August 1867 to November 1867) indicate that the soldiers were scouting for Indians and providing escort to cattle drives. Lt. Boehm and 50 enlisted men left the post on a scout on the Main Concho River, "to protect trains and droves of cattle crossing El Llano Estacado" (NA RG 617:195). Also in August, a small detachment of soldiers engaged a "large body of Indians" at Mountain Pass, about 40 miles from the post. In the action that ensued, two privates were killed and two horses captured. On August 25, one officer and 18 enlisted men left Ft. Chadbourne to reinforce the "Permanent Camp" on the Rio Concho, in response to information that Indians were concentrating in force in that vicinity (NA RG 617:195), but subsequent reports make no

Table 4-3. Early Texas Forts: Post-Civil War Period Posts, from North to South

\begin{tabular}{llll}
\multicolumn{1}{c}{$\begin{array}{c}\text { Military } \\
\text { Post }\end{array}$} & $\begin{array}{c}\text { Occupation } \\
\text { Dates }\end{array}$ & \multicolumn{1}{c}{$\begin{array}{c}\text { Nearest } \\
\text { Town* }\end{array}$} & \multicolumn{1}{c}{$\begin{array}{c}\text { Original } \\
\text { Detachment }\end{array}$} \\
\hline Ft. Buffalo Springs & $1867-1868$ & Jacksboro & 6th Cavalry \\
Ft. Richard son & $1868-1878$ & Jacksboro & 6th Cavalry \\
Ft. Griffin & $1867-1881$ & Albany & 6th Cavalry \\
Ft. Concho & $1867-1889$ & San Angelo & 4th Cavalry \\
\hline
\end{tabular}

* Nearest town used as a reference point, and may be not be contemporary with the military post. Ft. Richardson replaced Ft. Buffalo Springs at the same site. 
mention of further engagements with the Indians. In November 1867, a detachment of Company M, 4th Cavalry, was providing escort for cattle herds headed for the Pecos (NA RG 617:195).

\section{Fort Concho}

\section{Establishing Fort Concho}

The post at Ft. Chadbourne was abandoned for lack of good water (Bell et al. 1980), and headquarters of the command transferred to Camp Hatch on the Rio Concho on December 4, 1867 (NA RG 617:241). The name of the post was changed twice: first to Camp Kelley on January 1868, and finally to Ft. Concho on March 1868. The new post was strategically located at the center of operations and at the junction of the lines of communication, with the nearest post office located at Ft. Mason. Ft. Concho was situated 170 miles east-northeast of Ft. Stockton; 45 miles southsouthwest of Ft. Chadbourne; 54 miles northeast of Ft. McKavett; 145 miles northwest of Fredericksburg; and 270 miles northwest of San Antonio, location of the commissary and quartermaster depot (Crimmins 1934).

The post return for the month of December 1867 notes that Captain G. W. Hunt, 4th Cavalry, was in command of Companies A, D, G, H, and M with a complement of four officers, one surgeon, and 219 enlisted men. Each of the five companies had seven sergeants, Companies $\mathrm{A}$ and $\mathrm{D}$ had seven corporals apiece, Companies $\mathrm{G}$ and $\mathrm{H}$ had four corporals apiece, and Company $\mathrm{M}$ had five corporals. In addition, each company had three artificers, three farriers, and three blacksmiths (NA RG 617:241). The hospital department from Ft. Chadbourne joined the post on December 20, followed by Company $\mathrm{G}$ on December 24 (NA RG 617:241).

Numerous minor details were furnished by the Camp Hatch garrison during the month of December 1867. On December 10, one sergeant and six privates escorted a wagon train to Ft. Chadbourne for quartermaster's stores. On December 15, one sergeant and eight privates were sent on a mail-run to Ft. Mason. Also on the 15th, one officer, two non-commissioned officers, and 10 privates left the post on a 17-day trip to turn in "miserable horses" to the Quartermaster's Depot in San Antonio (NA RG 617:241). On December 19, one sergeant and 12 privates went out on a day's scout after Indians up the Rio Concho. On the same day, another group of soldiers, one officer, two non-commissioned officers, and 18 privates left the post on a scout after Indians toward the headwaters of the Rio Concho. This scout rejoined the post on the 23rd, "having found and buried the bodies of five citizens murdered by Indians" (NA RG 617:241). On December 26, one sergeant and six privates were sent out as escort for a wagon train on its way to $\mathrm{Ft}$. Chadbourne for hay. And on this same date, one sergeant and eight privates were sent out as a "mail express" to Ft. Mason (NA RG 617:241).

A descriptive account of the Ft. Concho area is expressed by General J. J. Reynolds, dated March 4, 1868:

Wood is neither convenient nor abundant, and will be scarce after another year. Grazing good, in the season; water good and abundant, in all seasons. The country is in a primeval state of nature, no cultivation of the soil, however small. Recentlyabout the 10th of February, 1868-a colony of emigrants, about (15) fifteen in number, settled on the Main Concho, about seven (7) miles from this post, and for the first time in the history of the country, broke ground for agricultural purposes. A post garden, for the use of the military of this post, is established there; the place is called "Bismarck," and from present indications ... it is evident, the soil is adequate ... but stock-raising, and not agriculture constitutes the sole occupation of those having business in this section... with the exception of Bismarck, there are none others who claim a local habitation for miles around [Crimmins 1934].

Actual construction of the post took several years to complete. The post return for the month of December 1867 listed well over 100 construction workers, "Quarter Master Department Employees." Besides the superintendent of mechanics, engineers, sawyers, and stone masons, the post added 20 laborers, 29 teamsters and herders, three ox drivers, a wagon master, and an 
assistant wagon master (NA RG 617:241). Such an increase in construction personnel indicates a major construction project. By March 1870, the buildings of the post were, in order of their construction, a commissary and quartermaster storehouse, a hospital, five officers' quarters, a magazine, and two barracks, all built of light-colored sandstone. A cistern, at much expense and labor, had been dug and blasted close to the hospital, but was left unfinished in February 1869 (Toulouse and Toulouse 1936).

According to Tetzlaff (1979), German masons and carpenters from Fredericksburg were hired to construct Ft. Concho in the fall of 1867 . By 1868 the stone for the fort's construction was being quarried at Benficklin, five miles away (Bell et al. 1980). As a result of worker dissension and mounting costs, these workers were released in June 1869, and the job was completed by an "unskilled Negro regiment and a few civilian journeymen." Tetzlaff fails to cite his source, but given the following three points his statement seems credible. Tetzlaff places the German workers in the area by fall 1867, and such workers were listed at Ft. Chadbourne by August 1867. It seems plausible that the Germans may have actually been hired to repair Ft. Chadbourne and then transferred and assigned the task of constructing the new post. Secondly, the African-American soldiers of the 9th Cavalry and 41st Infantry arrived on-post in March 1869 , and very likely would have been available for such duties. Between April 1869 and May 1870, the post was garrisoned exclusively by African-American soldiers (enlisted men). And lastly, the post returns for June and July 1869 do in fact demonstrate a drastic decrease in civilians employed. In June, there were 92 construction-related workers, but only one, a carpenter, in July. A slight increase in carpenters and masons was noted in the post returns for January 1870 through August 1870, and then again from September 1870 through October 1871. Between November 1871 and June 1873, the number of carpenters and masons fluctuated, but never exceeded more than nine carpenters or 16 masons at any one time. No construction-related workers were employed at Ft. Concho between June 1873 and November 1875, and only intermittently between December 1875 and May 1879 (NA RG 617:241). Another interesting footnote suggests that around 1870 the post consisted of "tents and a few jacals [picket and mud] structures" and that
Major John P. "Dobe" Hatch had briefly experimented with adobe as a building material (Bell et al. 1980). This last note also supports Tetzlaff's claim that Ft. Concho experienced some construction delays.

\section{The Fort Concho Scouting Reports}

The following briefs are based on the "Record of Events" noted in some of the post returns (1867-1885), and on actual scouting reports (1872-1882). This latter collection of data was taken from a transcription of Record Group 393 (Records of the United States Army Continental Commands, 1821-1920), located in the Fort Concho Library and Archives. Record of events taken from post returns often lack substance, but are worthwhile for lack of a better source. This section is offered as a means of highlighting Ft. Concho's contribution to the settling of the Western Frontier, as well as on how the various subposts and troops were utilized in these endeavors.

Between 1867 and 1869, six separate reports of Indian sightings and/or engagements were reported for $\mathrm{Ft}$. Chadbourne and Ft. Concho. Only three of these resulted in or made reference to loss of life. On August 8,1867 , a small scouting party from Ft. Chadbourne was attacked by a "large party of Indians," and two privates were killed and two horses stolen (NA RG 617.195). A few months later, December 1867, five dead citizens were located by a scout from Camp Hatch (NA RG 617.241). On October 28-29, 1869, Brevet Major Bacon with Companies B and E, 9th Cavalry, engaged a large party of Indians. Between 75 and 100 Indians were reported killed and wounded, with no indication of death or injuries to the soldiers (NA RG 617:241).

Around 1870, the Comanches and Kiowas, with some assistance from Kiowa-Apaches, Cheyenne, and Arapahos, continued to hinder the Euro-Americans' westward movement. A line of cavalry forts delineated the final frontier: Ft. Richardson, at Jacksboro; Ft. Griffin, near Albany; Ft. Concho, at San Angelo; Ft. McKavett, on the San Saba; and Ft. Clark, near Brackettville. Also by 1870 , the hunting of buffalo for hides had become a widespread and lucrative business. The buffalo hunters, working in groups of 
about a dozen, arrived with wagons, large amounts of ammunition, and heavy-caliber Sharps rifles. The buffalo were literally being exterminated along the Plains, and the Army and the general public along the frontier approved. The greatest tragedy was that these men left the carcasses of the animals to rot; only the skins were taken. In May 1879, Captain Norvell of the 10th Cavalry reported that the Big Spring was formerly occupied by hide traders, and that "the bones of many thousands of buffaloes, are scattered around" (Fort Concho Library and Archives [FC] Scouting Report [ SR], p. 282). The buffalo was the "free" Indians' staff of life; without it they would be bound to the reservation and the government's meager allotments (Fehrenbach 1968, 1974). To counter the Plains Indians' retaliation, the Army responded with a series of punitive expeditions led by Colonel Ranald S. MacKenzie, 4th Cavalry , between 1871 and 1875 (see Fehrenbach 1974:513-543).

Colonel MacKenzie commanded Ft. Concho briefly on two occasions. The first was between February 1871 and March 1871, the second was between January 1873 and March 1873 (NA RG 617:241). A review of the post returns (1871-1875) located only one instance in which troops from Ft. Concho were on detached duty to MacKenzie. In September 1871, Lieutenant Charles L. Hudson, with 51 enlisted men of Company G, 4th Cavalry, "returned as relieved from the command of the expedition against the Indians under Col. MacKenzie" (NA RG 617:241).

In March 1872, Major Hatch, 4th Cavalry, reported that Lieutenant Hoffman had sighted a party of about 150 men, believed to be from the reservation near Ft. Sill. These were reported as divided and operating in San Saba, Lampassas, and Llano counties, and may be the war party that had left the reservation (FC SR:14). There was no further mention of this large party of Indians. The following month, Captain McLaughlin, 4th Cavalry, was out scouting the country north and northwest of Ft. Concho with four officers and 88 enlisted men. While 77 miles northwest of the post, near Randlebrook Springs, the soldiers came across a large Indian camp. The captain reported no less than 153 lodges, and guessed that a party of between 150 and 200 Indians had been encamped, and that they had missed them by about a day. Captain
McLaughlin reported that "this Mucha-qua country is the edge of the stake plains, and situated as I was I did not feel justified in following the trail further" (FC SR:28).

The ensuing reports indicate that the Ft. Concho troops were rarely required to engage the Indians. While escorting several herds of cattle across the Staked Plains (November 1872), 2nd Lieutenant Shoemaker, 4th Cavalry, with 11 enlisted men reported "having seen no signs of hostile Indians" (FC SR:53). In August 1873, Captain Corney, with Companies A and G, 9th Cavalry ( 2 officers and 59 enlisted men, and a guide), on a seven-day scout, reported "no recent signs of Indians" (FC SR:67). Negative reports of Indian signs continued through 1876. Captain Nolan's report of November 1877 is much of the same, but is nevertheless interesting:

November 11, 1877 . . Captain Nolan, Co. A, 10th Cavalry ... (R)eport of a scout made by me and 12 men of Co. A, 10th Cavalry ... Left the Post on November 7th and marched to Kickapoo Creek ... November 9th Marched to the Junction of the Concho and Colorado River ... I here interviewed Some of the Settlers as to when Indians were last seen in this Vicinity. When they informed me that None had been Seen in the last three Years-During the last two days March No Signs of Indians Could be discovered. November 10th Marched to Girts Ranch on the Colorado River ... I again Made inquiries about When Indians were last Seen in the Neighborhood. And was informed Not in the last Three Years. I now Came to the Conclusion that there was no Indians in this Part of the Country And Concluded to return to the Post by the Fort Worth Stage road [FC SR:182].

Indian sightings and a few altercations were noted some two years later. For the most part, however, the troops were busy escorting cattle herds, stage coaches, and the mail, and constructing roads. In April 1879, Captain Norvell, Company M, 10th Cavalry, states "I am of the opinion that the Company was of infinite service in the protection of the extensive Cattle ranges in that vicinity" (FC SR:275). A few months later, in June 1879, Captain Keyes, Company D, 10th Cavalry, 
left Ft. Concho in search of Indians reported to have stolen horses. Captain Keyes reported that Lieutenant Ward with 10 men went south, and that he and 10 men went up toward the head of the North Concho River. A Company of Rangers going northwest toward Big Spring were encountered by Captain Keyes, who later returned to Ft. Concho after having "found no signs or trail of Indians and heard of none from any ranch" (FC SR:260). That same month, June 1879, 1st Lieutenant Ward, Company D, 10th Cavalry, left the post in pursuit of Indians reported to have stolen stock on the North Concho River. On July 2, Company $\mathrm{D}$ marched 60 miles to the Head of the Concho (Holland's Ranch) and camped. While at the ranch, Ward was informed that a group of Rangers were hunting for the trail of the same Indians, who they had fought on June 29. Company D located the site of the battle some 27 miles away, recovered the body of "Ranger Anglin," and buried him (FC SR:264-265). No further notations in reference to this incident were located.

A few Indian sightings were reported during July and August 1879, but no engagements ensued. By November 1879, 2nd Lieutenant Eggleston, 10th Cavalry, reported meeting with several ranchmen along the Colorado who reported that no Indians had been in the country for several months (FC SR:317). In June 1882, Captain Alex Keyes, 10th Cavalry, stated that "troops on the N. Concho have in my opinion become unnecessary." That same month, 1st Lieutenant Ward , "the entire country as far as I went is settled up by cow and sheep men, and I learned that most all the heads of the streams had cow ranches on them. No Indians had been in this country for several years. A company of Rangers is stationed at Colorado City and another in Canon [Canyon] Blanco" (Fort Concho Library and Archives [FC] Microfilm Record of Scouting Reports [MFR], p. 5).

One of the most important contributions made by the Ft. Concho troops occurred in the early summer of 1875. Special Order No. 106, dated May 31 and received June 5, 1875, ordered Lieutenant Colonel (LTC) W. R. Shafter, 24th Infantry to active operations in the field (NA RG 617:241). This was to be the largest ever scouting expedition of the Western Frontier (Crimmins 1934). LTC Shafter assumed command of a total of nine companies: Companies A, C, F, G, I, and L, 10th Cavalry; Companies D and F, 24th Infantry; and Company A, 25th Infantry (NA RG 617:241). According to Crimmins (1934), this was the largest military contingent to ever depart from $\mathrm{Ft}$. Concho, and included a company of Seminole scouts. An attempt to determine the exact size proved futile, given the difficulty in deciphering the post returns for June and July 1875. A conservative estimate of the size of this detachment is 500 (50 men per company). This force left Ft. Concho on July 14, 1875, with 65 six-mule wagons, a pack train of about 700 mules, and a beef herd (Crimmins 1934). "The troops fanned out across the Llano Estacado in order to map the region for the first time" (Bell et al. 1980). The column marched 30 miles per day. The map produced by 2 nd Lt. Thaddeus Jones, 10th Cavalry, was one of the most detailed ever, and was used as late as 1888 as a basis for Colton's Map of Texas (Crimmins 1934). LTC Shafter's expedition also reported on the resources of West Texas and served to effect the first big influx of large ranchers.

\section{Fort Concho Census Records}

The U.S. census records recorded at Ft. Concho for 1870 and 1880 were obtained and entered into a spreadsheet. Counts and average ages were calculated for different groupings based on place of birth, race, census year, and occupation. We have retained the categories recorded by the census takers. Today these groupings, especially race, would be constructed differently, but information that at the time was considered important could be lost by restructuring the groups. The census records represent the single point in time when the census was recorded and they do not reflect the total population at Ft. Concho for the year. This is a limitation, as other records from $\mathrm{Ft}$. Concho show that the military population fluctuated constantly. Nevertheless, these census records do provide an indication of the nature of the military population during the years of 1870 and 1880 .

The records for the years 1870 and 1880 can be compared to reveal a number of interesting differences. Table 4-4 shows that the birth place locations shift dramatically between 1870 and 1880 . Approximately 
Table 4-4. Number and Percent of Soldiers Birth Place by Census Year

\begin{tabular}{|c|c|c|c|c|c|}
\hline \multirow{2}{*}{ Birthplace } & \multicolumn{2}{|c|}{1870} & \multicolumn{2}{|c|}{1880} & \multirow{2}{*}{ Total } \\
\hline & \# & $\%$ & \# & $\%$ & \\
\hline Canada & 10 & 2 & 1 & 0.4 & 11 \\
\hline Europe & 105 & 20.5 & 2 & 0.8 & 107 \\
\hline Latin America & 0 & & 2 & 0.8 & 2 \\
\hline United Kingdom & 146 & 28.5 & 0 & 0 & 146 \\
\hline USA, North & 198 & 39 & 43 & 18 & 241 \\
\hline USA, South & 53 & 10 & 193 & 80 & 246 \\
\hline Total & 512 & & 241 & & 753 \\
\hline
\end{tabular}

49 percent of the soldiers in 1870 were from Europe and the United Kingdom and only 10 percent from the South in 187.0. In 1880 approximately 80 percent were from the South, and all other areas had declined dramatically.

The patterns in Table 4-4 are clarified when race affiliations are viewed for each census year (Table 4-5). Virtually all soldiers in 1870 were white, but 68 percent of the soldiers were black and 25 percent were mulattos by 1880 . This explains the sharp rise in southern born soldiers in the 1880 census records. This also suggests that the 1880 census records the presence of the Buffalo Soldiers at Ft. Concho.

Age was also considered in the census records (Table 4-6). The soldiers' average age in 1870 was 26.6 years, while in 1880 it was 27.7 years. The greater age of

Table 4-5. Race of Soldiers by Census Year

\begin{tabular}{|c|c|c|c|}
\hline Race & 1870 & 1880 & Total \\
\hline Black & 0 & 165 & 165 \\
\hline Mulatto & 0 & 60 & 60 \\
\hline White & 512 & 16 & 528 \\
\hline Total & 512 & 249 & 753 \\
\hline
\end{tabular}

Table 4-6. Average Age of Soldiers by Birth Place and Census Year

\begin{tabular}{|c|c|c|c|}
\hline Race & 1870 & 1880 & Total \\
\hline Black & 40.0 & 26.9 & 27.0 \\
\hline Mulatto & 18.0 & 27.3 & 27.2 \\
\hline White & 27.0 & 35.5 & 27.4 \\
\hline Total & 27.0 & 27.9 & 27.3 \\
\hline
\end{tabular}


1880 whites is unusual and is discussed in more detail below.

Greater detail is available from the 1880 census records. Because individuals used Camp Elizabeth, a more in-depth analysis is warranted. Table 4-7 illustrates that approximately 99 percent (191 of 193) of the soldiers born in the South were black or mulattos, while 72 percent (31 of 43) of Northern

Table 4-7. Number of Soldiers by Birth Place and Race, 1880

\begin{tabular}{l|ccc|c}
\multirow{2}{*}{ Birthplace } & \multicolumn{3}{|c|}{ Race } & \multirow{2}{*}{ Total } \\
\cline { 2 - 4 } & $\mathrm{B}$ & $\mathrm{Ma}$ & $\mathrm{W}$ & \\
\hline Canada & 1 & 0 & 0 & 1 \\
Europe & 0 & 0 & 2 & 2 \\
Latin America & 0 & 2 & 0 & 2 \\
USA, North & 24 & 7 & 12 & 43 \\
USA, South & 140 & 51 & 2 & 193 \\
\hline \multicolumn{1}{r|}{ Total } & $\mathbf{1 6 5}$ & $\mathbf{6 0}$ & $\mathbf{1 6}$ & $\mathbf{2 4 1}$
\end{tabular}

soldiers were Black or mulattos. In the other areas combined, 60 percent ( 3 of 5) were black or mulattos (abbreviated $\mathrm{Ma}$ ), but the numbers are very small.

The average age of soldiers presented in Table 4-8 indicates that whites were significantly older than blacks or mulattos. This is a pattern recognized above, but a more detail examination of these patterns reveals that foreign whites are slightly older than Americanborn whites and that Northern-born whites are older than Southern-born whites.

Table 4-9 presents information on military rank or occupation and racial affiliation. These data show that blacks and mulattos dominated the military in 1880 , but that the command was dominated by older whites. The highest rank held by a black was Sergeant. One significant difference between 1870 and 1880 is the dramatic shift from foreign to black soldiers. The
Table 4-8. Average Age of Soldiers by Birth Place and Race, 1880

\begin{tabular}{l|ccc|c}
\multirow{2}{*}{ Birthplace } & \multicolumn{3}{|c|}{ Race } & Overall \\
\cline { 2 - 4 } A verage
\end{tabular}

Table 4-9. Number of Soldiers by Rank/Occupation and Race, 1880

\begin{tabular}{|c|c|c|c|c|}
\hline \multirow{2}{*}{$\mathrm{Rank} / \mathrm{Occ}$} & \multicolumn{3}{|c|}{ R a ce } & \multirow{2}{*}{ Total } \\
\hline & B & $\mathrm{Ma}$ & w & \\
\hline Captain & 0 & 0 & 1 & 1 \\
\hline $1 \mathrm{st} \mathrm{Lt}$. & 0 & 0 & 1 & 1 \\
\hline $2 n d L t$ & 0 & 0 & 1 & 1 \\
\hline Lt. Sergeant & 0 & 1 & 0 & 1 \\
\hline Post Surgeon & 0 & 0 & 1 & 1 \\
\hline Post Physician & 0 & 0 & 1 & 1 \\
\hline$B$ and $M$ aster & 0 & 0 & 1 & 1 \\
\hline Sergeant & 5 & 0 & 0 & 5 \\
\hline Trumpeter & 1 & 1 & 0 & 2 \\
\hline Post Trader & 0 & 0 & 1 & 1 \\
\hline B lack Smith & 1 & 0 & 0 & 1 \\
\hline Farrier/Soldier & 0 & 1. & 0 & 1 \\
\hline Saddler/Soldier & 1 & 0 & 1 & 2 \\
\hline Corporal & 3 & 1 & 0 & 4 \\
\hline Private & 44 & 8 & 0 & 52 \\
\hline Soldie r & 110 & 48 & 8 & 166 \\
\hline Total & 165 & 60 & 16 & 241 \\
\hline
\end{tabular}

composition of the U.S. military was still strongly biased by the Civil War in 1870 and 1880 , especially in terms of Southern white enlistment. Table 4-9 illustrates that approximately 93 percent ( 225 of 241) soldiers were black or mulattos in 1880 . 


\section{Fort Concho Subposts}

Captain R. G. Carter's account of Ft. Concho around 1870 relates that several subposts or intermediate stations were located at various intervals, and served more as a means for rapid communication, by courier between posts, rather than to fulfill any practical offensive or defensive purpose (Figure 4-3). No railroads ran between the posts, and the roads connecting these posts with the outside world were rough stage roads. The "relays," or stage stations were located about 20 miles apart (Carter 1961).
Among the first Ft. Concho subposts was Camp Charlotte, established in April 1868, just below the mouth of Kiowa Creek, 42 miles west of the post. The "old mail station" called Head of the Concho was located 10 miles away, to the west-northwest of Camp Charlotte. By June 1868, Camp Charlotte had established "a picket dependency" referred to as Central Station or Middle Station (Haley 1952). By mid-summer of 1869, Ft. Concho had subposts, or "picket posts" at Camp Charlotte, at the Head of the Concho, at Johnson's Station "near present Arden," at old Ft. Chadbourne, and at Lone Tree (Haley 1952).

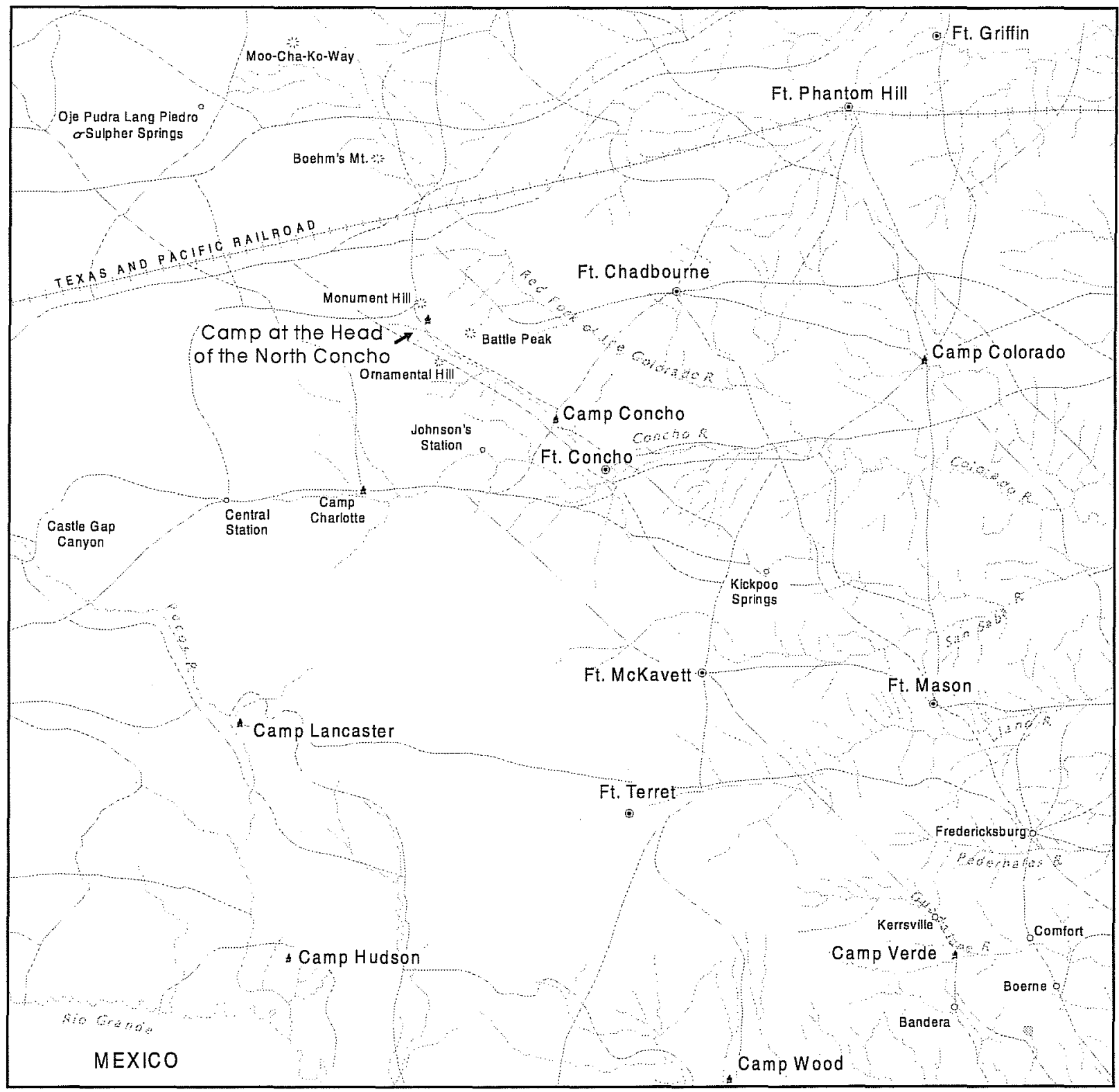

Figure 4-3. Fort Concho and outposts, ca. 1875. Courtesy of the Texas State Archives. 
In fall 1869 , orders were issued for permanent guards at the Head of the Concho, Johnson's Station, and Chadbourne. Captain Gamble, 9th Cavalry, in command of the post, was ordered to erect a stone building, $30 \mathrm{ft}$ long by $10 \mathrm{ft}$ wide, with two rooms (one for the guard of an officer and four men, and the other as a stable for their horses) at the Head of the River (Haley 1952). The building at Johnson's Station was to be on the same plan, "roofed with poles, covered with mud and should be so placed that the sentinel watching the stable could also watch that of the Mail Company." In addition to this slender garrison, Captain Gamble was ordered at his discretion to keep a detachment of as many as 25 "well-mounted men at the Head of the Concho." Two men of each regular picket should be Cavalry, and the rest either Infantry soldiers or dismounted Cavalry" (Haley 1952).

Prior to May 1871 , the post returns did not specifically list subposts or outposts. These subposts were mentioned on the "Record of Events," and primarily noted as a result of "relieving" of detachments (NA RG 617:241). For example, the post returns for January and March 1871 note that the "Monthly relieving of detachments stationed at Head of Concho, Johnson's Station, and Ft. Chadbourne took place on the 24th [January ] and 27th [March]." The post return for May 1871 includes a subheading for "Outposts," and lists six: Head of the Concho, Johnson's Station, Ft. Chadbourne, Kickapoo Springs, Concho Mail Station, and Bismarck (NA RG 617:241). In terms of the number of men posted at such outposts, the first indication is given on the post return for January 1872: one officer and 32 enlisted men at Ft. Chadbourne, four enlisted men at Johnson's Station, five enlisted men at Head of Concho, and seven enlisted men at the Concho Mail Station (NA RG 617:241).

Ft. Concho maintained a large number of men at the subpost of Ft. Chadbourne for a brief three months in January through March 1872. Only a handful were posted after the latter date, and the subpost was apparently not used again after June 1872 (NA RG 617:242). The only other marked increase in the number of men posted occurred between May 1880 and September 1882. During this latter period, Camp Charlotte, Grierson's Spring, and Head of the North Concho usually had between 41 and 71 men posted.
Between November 1881 and March 1882, the subpost at the Head of the North Concho had well over 100 men posted: Companies $\mathrm{G}$ and $\mathrm{L}, 10$ th Cavalry, with five officers and 104 enlisted men, and Company D, 10th Cavalry, with three officers and 146 enlisted men (NA RG 617:242).

The subposts were not permanently located and changed depending on the needs of the post. Some were added, others abandoned and, in some cases, reutilized. By the early 1880 s, Ft. Concho listed only three subposts: Grierson's Springs, Camp Charlotte, and Head of the North Concho. Neither these subposts, nor any others, were listed after September 1882 (NA RG 617:241). September 1882 marks not only the last time a sizeable force was detached at any of the subposts, but the end of Ft. Concho's use of subposts.

The preceding discussion makes mention of a subpost at the "Head of the Concho" which is not to be confused with the subpost at the "Head of the North Concho." The former subpost was located about 40 miles west of Ft. Concho, along the Main Concho River, and the latter was located about 60 miles northwest of the fort, along the North Concho River (Figure 4-4). A scouting report entry of November 1872 relates that the engineer corps of the Texas and Pacific Railroad encamped on the road between Ft. Concho and the Head of the Concho River about 40 miles from the post of Ft. Concho (FC SR:53). Captain Norvell's report of activities for March 1880 notes that Company M, 10th Cavalry, marched 60 miles northwest of the post to the Head of the North Concho (FC SR:296).

Based on a combination of scouting reports and post returns, we now know that the subpost at the Head of the Concho (Main Concho River) served as a subpost and mail station from ca. July 1869 to November 1878 . Throughout this eight-year period, the mail station was typically guarded by one non-commissioned officer and three privates. The last entry for this site was November 1878, at which time Ft. Concho ceased to post a regular guard at the Head of the Concho.

Camp Elizabeth, or the subpost at the Head of the North Concho, did not have a detachment assigned to it until fairly late. The first mention of this site is found 


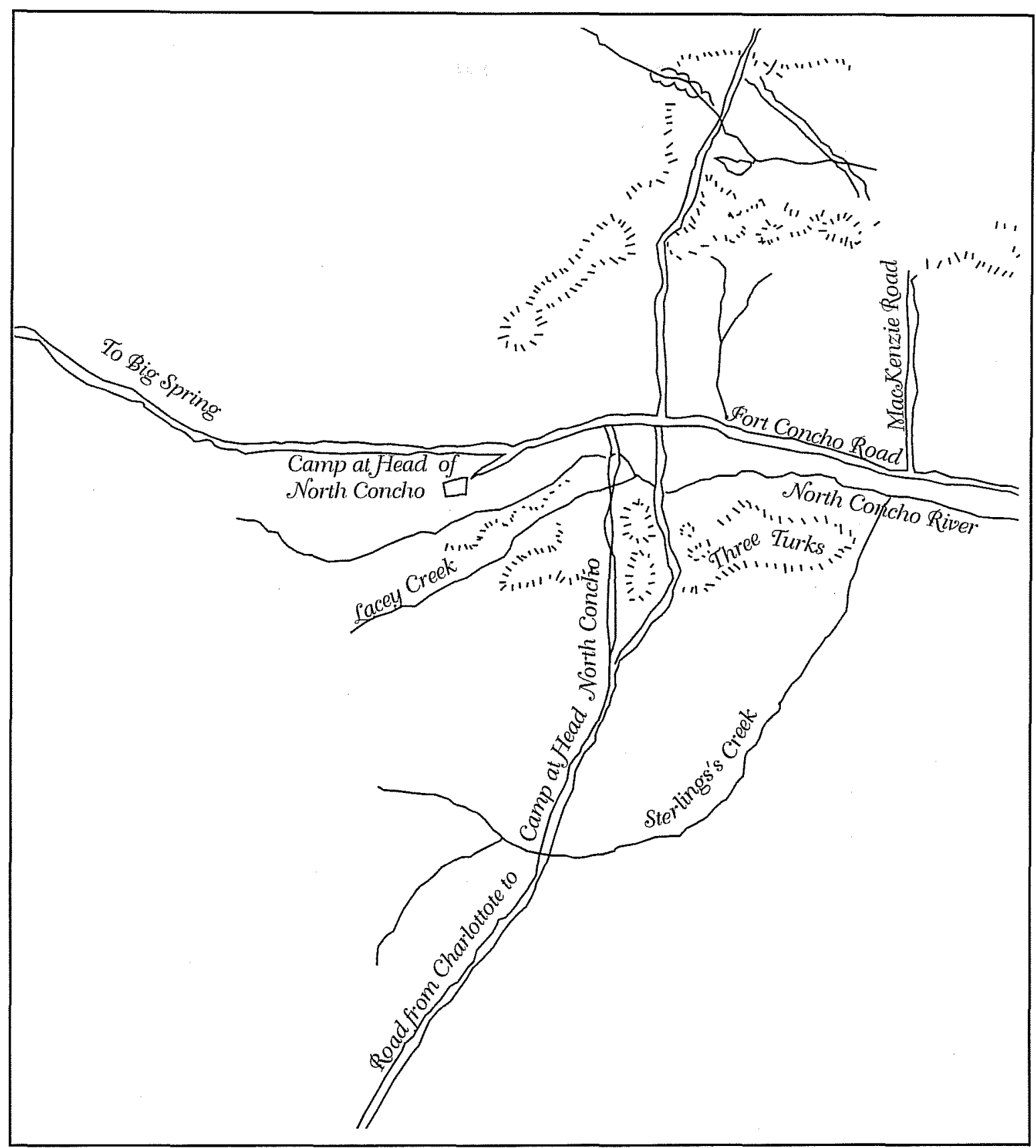

Figure 4-4. Ft. Concho Scout Report map of the location of Camp at the Head of the North Concho. Redrafted from the original. Lettering approximates original style.

in Captain Corney's scouting report of August 1873, in which he details that Companies $A$ and $G$, 9th Cavalry, with two officers and 59 enlisted men, marched from Ft. Concho en route to the Head of the North Concho (FC SR:67). There was no mention of the site having been used as a camp. The first mention of its use as a camp is found in an August 1879 "report of activities" authored by 1st Lieutenant Ward, 10th
Cavalry. Writing from the "Head of the North Concho, Texas," Ward mentions that he and 10 enlisted men, with five citizens, left the "supply camp" in pursuit of "Indians reported to have been near the ranch of $\mathrm{Mr}$. Manning" (FC SR:307). The following month, Captain Keyes, 10th Cavalry, mentions that he and his men left "Supply Camp at Head of North Concho and marched on road to Moss Springs" (FC SR:312-13). 
Throughout the early- and mid-1880s, several companies of the 10th Cavalry and 25th Infantry began the construction of three camps and associated roads to the west and northwest of Ft. Concho. These operations were initiated in response to Special Order No. 29 of November 1879 and Special Order No. 6 of March 1880, from Headquarters, District of the Pecos (FC SR 319, 329). On November 26, 1879, Captain Gray, "with all available officers and men of Company K, 25th Infantry" left Ft. Concho en route to Grierson Springs, a distance of 85 miles, arriving there on November 30 (FC SR:319-20). According to the May 1880 post return, Company $\mathrm{K}$, 25th Infantry, was comprised of two officers and 42 enlisted men (NA RG 617:242). Captain Gray reported that during the company's stay at Grierson Springs, they were "employed in building, escort, and scouting duty ... A stone corral and stables with capacity for horses was constructed with a thatched roof. A guard house was constructed also, built of stone with the roof of thatch, it contains two rooms each twelve feet square in the clear. The timber used was obtained in Lancaster Canon [Canyon], 12 miles south of the Spring." Captain Gray also reported that "parties were out constantly cutting roads and grass and scouting" (FC SR:320-21). In October 1880, the command at Grierson's Spring requisitioned "two barrels of cement, one keg of 10D nails, and as much line as can be hauled" (FC MFR:5).

Captain French, Company A, 25th Infantry, reported that he, with a command of two officers and 40 enlisted men, left Ft. Concho on June 6, 1880 and took station at Camp Charlotte (FC SR:323-24). Captain French further reported that as weather permitted, his command commenced work on the roads near Camp Charlotte and toward the North Concho. He was compelled to make two trips, since there was more work to be done than at first anticipated, "seven crossing of creeks and arroyos and two bad hills to be worked," and that there were "many miles of it to be cleared of trees, stumps, and stones" (FC SR:323).

The operations of the third camp, at the Head of the North Concho River, were aptly recorded by Captain Norvell, Company M, 10th Cavalry. His report of activities from March 1880 to September 1880 indicates that he and his command left Ft. Concho on
March 21, marching 60 miles to the Head of the North Concho River, and arrived there on March 23 (FC SR:329). Company M, 10th Cavalry, was comprised of three officers and 63 enlisted men (NA RG $617: 242)$. A July 1880 memorandum from Headquarters, District of the Pecos, directs that rations be sent to Captain Norvell for August. This same directive requires that on the company's return trip from the Head of the North Concho "the mason and such material and tools as are needed to build tanks" be taken to Grierson's Springs (FC MFR:5). Captain Norvell's report of October 1880 pointed out that the site was "selected by the District Commander as the site for a camp for the season to scout from." The rest of his report is pertinent to the study of Camp Elizabeth, and an abridged facsimile follows:

October 5, $1880 \ldots$ My instructions required the Country to be patrolled from camp Charlotte to the head of the Colorado River, and beyond, in the direction of Canon Blanco; also, West, to the white Sand Hills, and Rio Pecos . . . (T)he Country West of the Staked Plains, the head of the North Concho River, Moss, Big Sulphur, and Rattlesnake Springs, and the head of the Colorado River are now the Centers of Cattle ranges, and, in fact, all the Country bordering on the Colorado River is fast becoming settled and soon, all watering points will be occupied ... (I) $t$ will not be long before this will all be taken up by settlers. . . As a grazing Country, it is Splendid. Abundance of lime and sand stone can be found, but hardly any timber, of course as usual in Texas "Mesquit" flourishes ... Stone for building purposes can be found at almost any point on the Colorado River ... Eight miles west of Peck's Spring is a salt lake. Here I spent hours in searching for water . . . In "prospecting" rotten lodge poles were found, also an old gun barrel, which was pretty good evidence that indian village had once existed here. This made us more determined to find water, and finally, we were awarded with success, for after Cutting through rock ten inches thick with an axe and knives, at the depth of seven feet, good water was struck, which flowed in fast enough to water all the animals as fast as it could be passed up in a Camp Kettle. I think this water is permanent, and with a little work it can be available for the use of a Camp ... The water is in a ravine at the South 
West corner of the lake, and about 58. [miles] West of the head of the North Concho River. It is about 15 miles south of the line, as now staked out, of the Texas, Pacific Rail-Road . . In case of Indian troubles it would be a good point for an Infantry Command, expect it will have to be occupied at some time by troops for the protection of the railroad, which will pass near this point ... I returned to camp at the Head of the North Concho River, via Castle Mts, China Pond, Grierson's Spring, and Charlotte. From April $30^{\text {th }}$ to September $30^{\text {th }}$ parties were constantly patrolling the Country from my Camp. During the above period no an indian nor sign of one, was seen West of the Pe$\cos$. This was due, of course, to the troops West of the Pecos, being constantly on the alert ... A strong objection to occupy the Camp at the head of the North Concho River another year, is its proximity to the towns about Ft. Concho. It was with difficulty that I carried out the orders of the District commander in relation to traders and other Camp followers. Every pay day the Camp was besieged by traders and gamblers, and as they could get shelter at any point on the river, they were, without actually causing trouble or annoyance ... The health of the men of the Company was excellent, due to the fact they were furnished fresh meat and vegetables regularly ... The total distance marched during this period the Company was in the field was 4675 miles... /s/ S. T. Norvell, Captain 10th Cavalry, Comdg Co "M" (FC SR:329-332).

Captain Norvell's report sheds light on the mission of these late-developing subposts, as well as an indication of the study area's geography and early development. That Company M, 10th Cavalry, was at the forefront is of particular interest to the history of Camp Elizabeth. Over the course of this camp's 2.5-year history, Company $M$ served for the first seven months and was posted at this site two more times for an additional six months. A review of the available records, scouting reports, and post returns indicates that Camp Elizabeth was intermittently occupied by Companies D, F, G, L, and M, 10th Cavalry, and Companies $\mathrm{C}$ and F, 16th Infantry. The last piece of data available for this subpost was in the form of a memo written by Captain Rose, 16th Infantry, and directed to the commander at Ft. Concho. The memorandum, dated October 3,1882, requests that Dr. Finely and his wife be allowed to stay awhile longer so that they may care for one of the men who was suffering from a fever. Captain Rose states that the doctor "prefers to stay here and I think the chances are that he will do better by staying here. Dr. Finley's opinion as this is a very healthy place, none being sick except those who came here sick" (FC MFR:5). The first posting of this subpost was in March 1880 and the last in October 1882 (Table 4-10).

Although at least one of the subposts was garrisoned as late as October 1882, two pieces of correspondence dated August 1882 suggested that they be abandoned. An August 22 memorandum from Headquarters, San Antonio, Texas, authorizes the Ft. Concho commander to abandon the subpost of Grierson's Springs, "when in your judgment no longer needed." This same fate was to befall the one at the Head of the North Concho, as soon as a "new location can be decided upon." As for the other subpost: "No necessity is seen here for keeping up Camp Charlotte. In a few days a decision will be sent to you as to hay for North Concho" (FC MFR:5). The second memorandum is dated August 28,1882 , and directly effects the subpost at the Head of the North Concho. The memorandum from Headquarters, San Antonio, Texas, to the Ft. Concho command states, "soon hay need not be provided for [Head of the] North Concho for winter months. As soon as the grazing there shall have failed, you are authorized to abandon the camp" (FC MFR:5).

\section{The Abandonment of Ft. Concho}

Beginning in the $1880 \mathrm{~s}$, although political considerations made organized departure difficult, the Army began a gradual withdrawal of most of its Texas posts: Ft. McKavett and Ft. Duncan in 1883, Ft. Stockton in 1886, Ft. Concho in 1889, and Ft. Ringgold and Ft. Brown in 1906 (Wooster 1987). Also during the 1880 s, the Army shifted its attention and resources farther west to in Arizona, New Mexico, and the Dakotas. Between 1880 and 1883, two major railroads had been laid out across West Texas: the Galveston, Harrisburg, and San Antonio Railroad; and the Texas and Pacific Railroad. Nevertheless, throughout the 1880s, the Ft. Concho troops continued scouting the 
Table 4-10. Subpost at the Head of the North Concho River, Texas-Fort Concho Detachments

\begin{tabular}{ll}
\hline \multicolumn{1}{c}{ Date } & \multicolumn{1}{c}{ Remarks } \\
\hline $3 / 23-10 / 1 / 1880$ & Capt. Norvell w/Co. M, 10th Cavalry - 3 officers \& 63 enlisted men \\
\hline $3 / 10-5 / 21 / 1881$ & Capt. Norvell w/Co. M, 10th Cavalry \\
\hline $3 / 17-5 / 17 / 1881$ & Capt. Keyes w/Co. D, 10th Cavalry \\
\hline $2 / 22-719 / 1881$ & Capt. Wedemeyer w/Co. F, 16th Infantry \\
\hline $8 / 25-119 / 1881$ & $\begin{array}{l}\text { 2nd Lt. Stedman, 16th Infantry on detached service to Head of the North Concho-assumed } \\
\text { temporary command of L Troop, 10th Cavalry }\end{array}$ \\
\hline $6 / 6-11 / 24 / 1881$ & $\begin{array}{l}\text { Capt. Lee w/Co. G, 10th Cavalry } \\
\text { (Capt. Lee w/Co. G \& L, 10th Cavalry left for Ft. Stockton -Nov 24th) }\end{array}$ \\
\hline $1 / 26-4 / 1 / 1882$ & Capt. Norvell w/Troop M, 10th Cavalry \\
\hline $3 / 27-7 / 19 / 1882$ & Capt. Hayes w/Troop D, 10th Cavalry (146 enlisted men). \\
\hline $6 / 26-9 / 28 / 1882$ & Capt. Kennedy w/Troop F, 10th Cavalry \\
\hline $9 / 23-10 / 1882$ & $\begin{array}{l}\text { Capt. Rose w/Co. C, 16th Infantry left subpost at Head of the North Concho } \\
\text { (No other entries or mention of subposts after this last date.) }\end{array}$ \\
\hline
\end{tabular}

Note: The number of men posted was available in only two instances.

Western Frontier, but as aptly stated by Captain Keyes and 1st Lieutenant Ward, "the entire country had been settled" by 1882, and "no Indians had been sighted" for several years. Ft. Concho was finally abandoned on June 20, 1889 (NA RG 661:2.341). By this late date, the town of Big Spring (1882) had already been established, and Sterling City was well on the way to being established. Figure 4-5 illustrates the ca. 1890 Western Frontier, and demonstrates the development that occurred after 1875 .

\section{The Buffalo Soldiers, 1867-1885}

The Plains Indians called the African-American soldiers who patrolled the western frontier with the post-Civil War Army "Buffalo Soldiers." More than 180,000 Black soldiers served with distinction in segregated units of the Union Army during the War between the States, and many of the units were recognized for outstanding combat records with the Medal of Honor awarded to 32 of these soldiers (Schubert 1997). Following the war, the Republicans insisted that to meet the need for additional troops on the western frontier, the "Blacks in blue" be considered for a place in the regular army (Foner 1974). In 1866, by Act of Congress, the reorganization of the peacetime regular army authorized two regiments of black cavalry, the 9th and 10th United States Cavalry, and four regiments of black infantry, the 38th, 39th, 40th and 41st Infantry (Schubert 1997).

Major General Philip H. Sheridan, commander of the Military Division of the Gulf, was authorized to raise the 9th Cavalry Regiment. Colonel Edward Hatch began recruiting in New Orleans and Baton Rouge in August, and in the remainder of Louisiana by October (Carroll 1971; Schubert 1997). Recruiting was also conducted from Louisville and Lexington, Kentucky, to complete the unit (Schubert 1997). Lt. General Sherman, Military Division of the Mississippi, authorized Colonel Benjamin H. Grierson and Lt. Colonel Charles C. Walcutt to recruit the men for the 10th Cavalry. Headquartered at Ft. Leavenworth, Kansas, they recruited 1,092 men from Louisville, Kentucky, and Philadelphia, Pennsylvania (Carroll 1971). The officer corps for all six units of black soldiers was composed entirely of white officers until 1877 (Wooster 1987). 

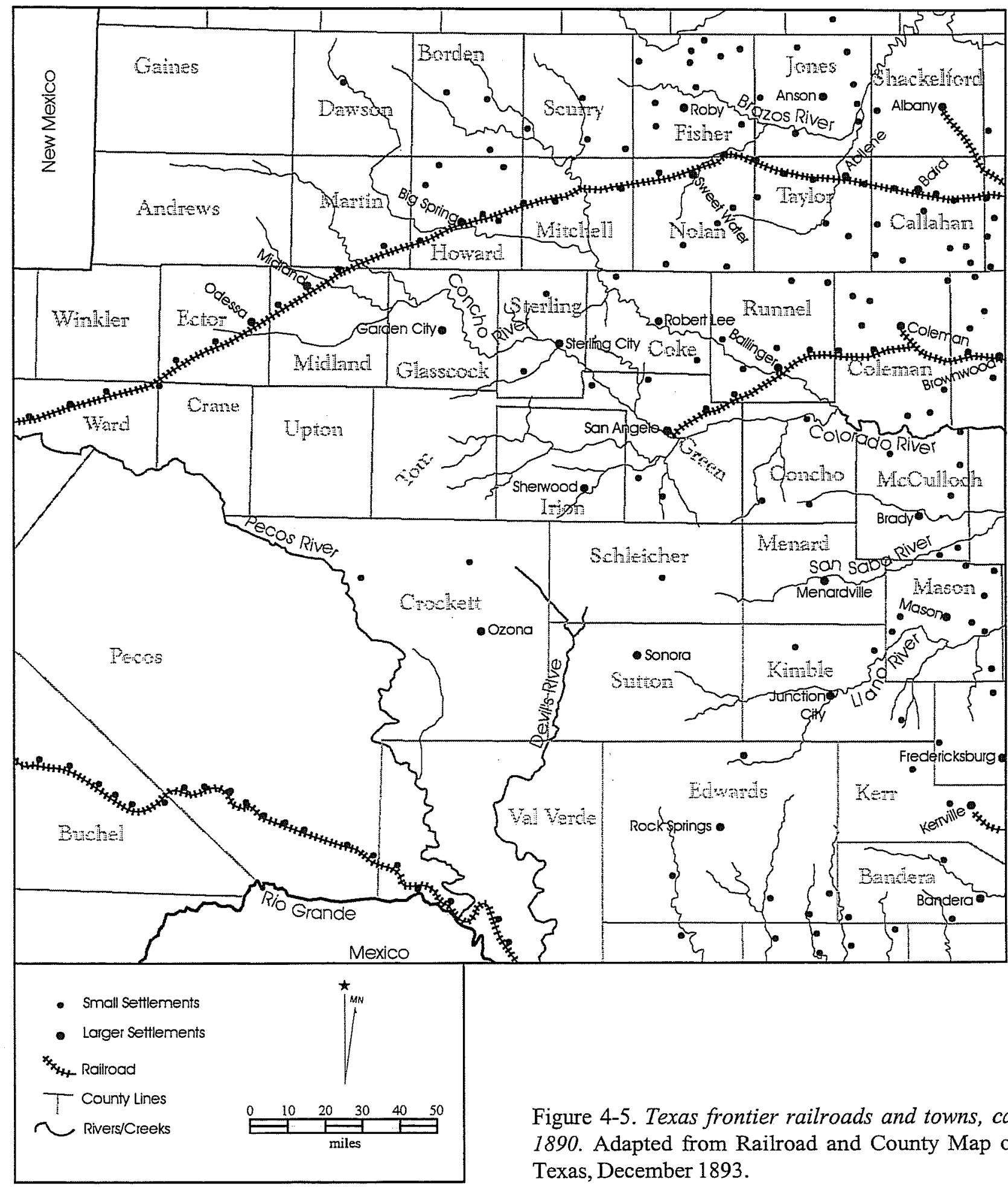

Figure 4-5. Texas frontier railroads and towns, ca. 1890. Adapted from Railroad and County Map of Texas, December 1893.

Desertion was significantly lower among black regiments than other units of the army. In 1867, for example, one-quarter of the entire U.S. Army deserted, as opposed to four percent of black troops (Wooster 1987). Yet significant problems existed. Among the hundreds of enlistees, only a few could read or write. The Army attempted to compensate by appointing chaplains who were assigned both the educational and religious needs of the troops (Schubert 1997). None of the recruits possessed any of the basid military skills 
and had to be taught horsemanship, mounted drills, and handling of the carbine revolver and saber (Schubert 1997). The 9th Cavalry, stationed initially in New Orleans, faced a city still tense from the race riots of July 1866 where blacks demonstrated for civil rights, resulting in 38 deaths, mostly black. The recruits found themselves crowded into unsanitary and poorly ventilated buildings, and as a result lost 29 of their number to cholera between October and December. From a unit that ultimately became noted for its low rate of desertion, 30 men disappeared before the end of 1866 (Schubert 1997). protecting the settlers from bandits and the Comanche, Kiowa, Cheyenne, Arapaho, and Sioux, as well as the Apache and Nez Perce. The cost of this training in action was high, with six men slain in engagements before the end of the year: Private Nathan Jones of $F$ Troop from Ft. Davis, and Privates Edward Bowers, William Sharp, and Anderson Trible of K Troop of Ft. Lancaster (Schubert 1997).

In 1867, the 10th Cavalry was headquartered at Ft. Riley, Kansas, but had troops stationed at Ft. Hayes,
The bitter winter of 1967 ended with 873 enlisted and 11 officers of the 9th Cavalry boarding ships for transport to Indianola, Texas (Schubert 1997). The number of line officers was well below the 36 provided for by law, but Colonel Hatch had difficulty in interesting white officers to fill the positions (Wooster 1987). On March 29, 1867, the 9th Cavalry disembarked from the steamers at Indianola, and began the 150mile march to San Antonio, where they reported to camp at San Pedro Springs for three months of training. After this short period, the unit was assigned to duty in west and southwest Texas (Figure 4-6). Troops A, B, E, and $\mathrm{K}$ were assigned to headquarters at Ft. Stockton, with Colonel Hatch commanding; Troops C, D, $F, G, H$, and I were assigned to Ft. Davis, with Lt Colonel Merril in command (Carroll 1971). During their first year on the frontier of Texas, their duties consisted of mixed garrison duty and training, and their mission included escorting the mail and

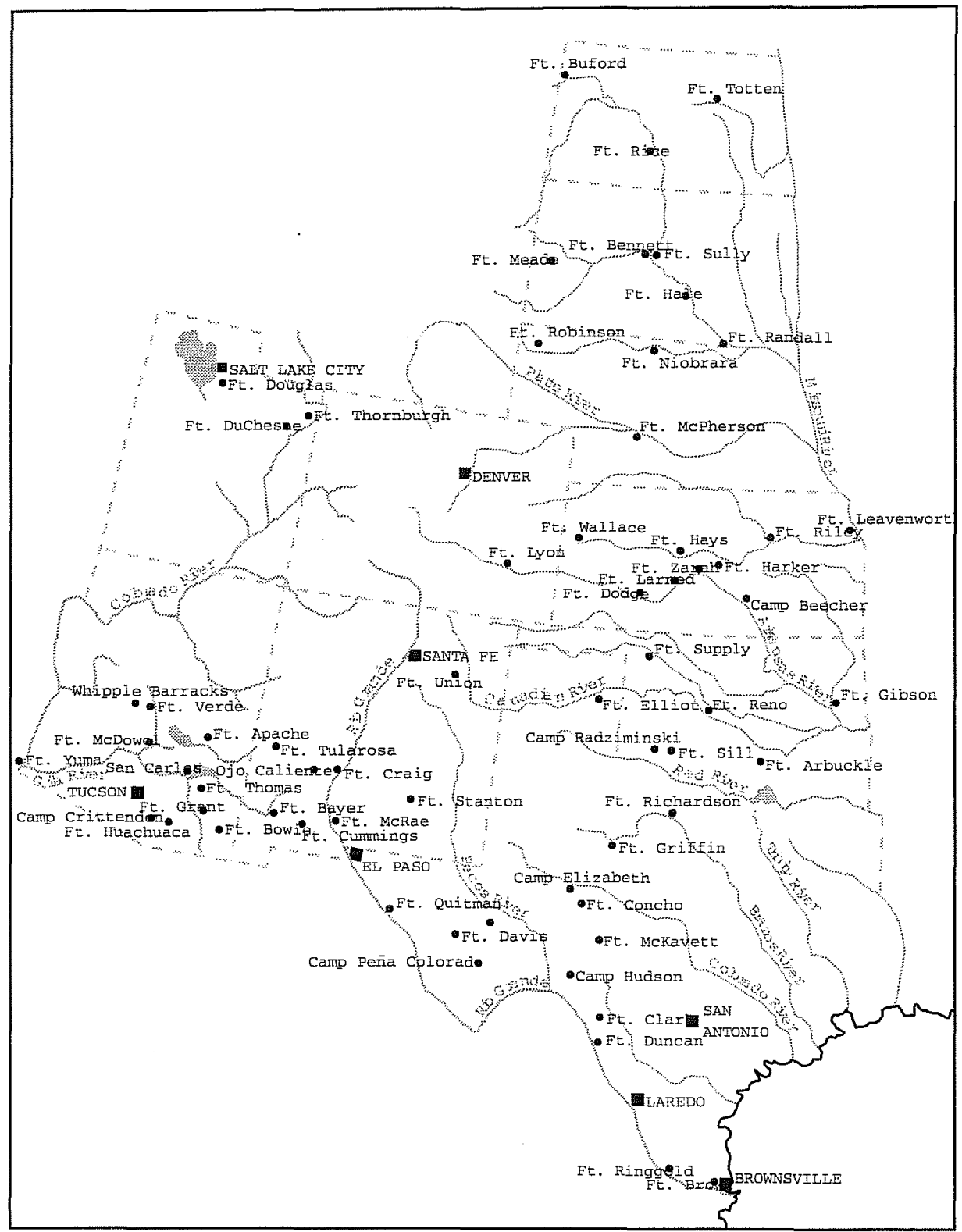

Figure 4-6. Forts occupied by the Buffalo Soldiers. Adapted from Leckie (1967:69). 
Ft. Harker, and other posts along the Smokey River and along the line of the Kansas-Pacific Railroad (Figure 4-7). The unit was manned by 25 white officers and 702 enlisted black soldiers. In January 1869, the 10th Cavalry and the 6th Infantry had been reassigned to Camp Wichita, Indian Territory, and an old Indian village was selected as the site of a new military post, later to become Ft. Sill (Carroll 1971).
(Schubert 1997). The typical black recruit was an illiterate laborer or farmer, for whom enlistment in the army offered an opportunity of a steady income. Substantial numbers reenlisted. Both black and white soldiers received a basic starting pay of $\$ 13$ a month for privates, with annual increases of one dollar per month after the second year of service and a bonus after each five-year enlistment (Foner 1974).
In March 1869, Company B, 9th Cavalry, and Company E, 41 st Infantry, marched the 169 miles from Ft. Stockton to man Ft. Concho. This added four officers and 96 enlisted men to the rolls of Ft. Concho (NA RG 617:241). In December of that year, F Troop was relocated to Ft. McKavett (Schubert 1997).

In August 1870, Major Zenas R. Bliss, 25 th Infantry, enlisted a special detachment of black Seminole scouts from a group that had recently arrived at Fort Duncan from northern Mexico. These people represented a portion of the mixed-blood Seminole and black population that had fled to Mexico during 1849 and 1850 to escape American slave traders. They had originally been well received by the Mexican government but eventually had been neglected. An offer of scouting jobs and protection tendered by Captain Frank W. Perry had prompted about 100 to relocate to Fort Duncan, under subchief John Kibbetts. In the following three years, other groups from northern Mexico joined them, raising the black Seminole population to approximately 180 (Tate 1996:572-573). Fifty scouts were organized as a unit and served for nine years under Lt. John Bullis (Foner 1974). In 1875, Adam Payne became the first Seminole Indian scout to receive the Medal of Honor for heroism during the Red River War of 1874-1875 (Schubert 1997).

In the years following the war, black soldiers constituted about 10 percent of the effective strength of the army. In 1870, the total Army rolls listed 30,000 officers and enlisted men, of which 2,700 were blacks
A high priority for the Department of Texas was the construction of military telegraph lines. The task of erecting the poles and stringing the lines was assigned to the infantry. This task occupied a great deal of their time for months (Fowler 1971). The 9th Cavalry was stationed at seven posts, stretching along a line 630 miles, anchored in the west by Ft. Quitman, eastward through Ft. Davis and Ft. Stockton, and then south toward Ft. McKavett and to Ft. Duncan (Schubert 1997). An inspection report of Ft. Concho in April 1870 noted: "The Post is now garrisoned by three Companies, $\mathrm{B}$ and $\mathrm{E} 9$ th $\mathrm{Cav}$ and $\mathrm{F}$ 24th Infy, all colored . . . (NA RG 858:4688).' In September, Ft. Concho furnished escorts for the U.S. mail to Ft. Smith, El Paso, and Taylor's Rancho, and guards for several other mail stations (NA RG 1965:617.241).

At the end of April 1873, the 10th Cavalry was transferred to the Department of Texas. Troops E, I, and $\mathrm{L}$ reported to Ft. Richardson, Troops $\mathrm{C}$ and D moved to Ft. Griffin, and Troop F went to Ft. Concho. The 10th Headquarters was transferred from $\mathrm{Ft}$. Sill to Ft. Concho at that time. In 1875, the 9th Cavalry was transferred to New Mexico, with headquarters at Santa Fe, for the next five years. The headquarters for the 10th remained for seven years at Ft. Concho, with the regiment modified and effectively scattered throughout the length of Texas (Carroll 1971).

In the spring and summer of 1875 , the number of Indian raids increased dramatically, causing an outcry for more protection from the army (Fowler 1971). In 
July the largest military contingent to ever depart from Ft. Concho, comprised of nine troops of the 10th Cavalry and three companies of the 24th and 25th Infantry (Figure 4-8), spread out across the Llano Estacado to map the region for the first time (Bell et al. 1980). This large scouting expedition organized under Lt. Colonel William Rufus Shatter explored the West Texas plains and reported favorably on the resources of the region, resulting in the first large influx of ranchers. This army departed Ft. Concho July 14 , with 65 six-mule wagons, a pack train of about 700 mules, and a beef herd. This survey of the plains, mapped by 2 nd Lt. Thaddeus Jones, of the 10th Cavalry, was the most important made and served until 1888 as the major source of information about the area (Crimmins 1934).

In 1880, Colonel Benjamin Grierson and the 10th Cavalry departed Ft. Concho to assist the 9th Cavalry in their efforts to subdue the Apaches. Element of the 24th and 25th Infantry accompanied the unit to the west (Schubert 1997). By this time, despite political pressure, the army began to gradually withdraw from its remaining Texas outpost. Ft. McKavett and Ft. Duncan were closed in 1883, Ft. Concho in 1889, and Ft. Ringgold and Brown in 1906 (Wooster 1987).

During the period of the Indian Wars, 1869-1890, black soldiers won 14 Congressional Medals of Honor, nine Certificates of Merit, and 29 Orders of Honorable Mention. During the same period, among the 50 Seminole Indian Scouts were four Medals of Honor. The Buffalo Soldiers performed with honor in nearly 200 engagements, both major and minor (Foner 1974). After the period of the Indian Wars, the four regiments continued in service with some elements participating in the Spanish-American War, the Philippine Insurrection, and John Pershing's 1916 punitive expedition into Mexico.

\section{Summary and Discussion}

\section{The Texas Rangers}

Previous researchers have noted that it is often difficult to distinguish between the early Rangers and the militia or regular soldiers. Since the Rangers' service was intermittent, and their posts neither well defined nor mentioned in the official records, the extent of their scouting in the area of Ft. Concho is unclear. The earliest records of the Rangers' presence near the study area date to December 1854 (TSA RG 401:1153.21; $401: 1153.22 ; 401: 1153.23)$. The first notes that Captain Rodgers purchased supplies for two companies of "Mounted Volunteers" at Johnson's Station. The second is from a Fredericksburg blacksmith, requesting payment for having repaired several firearms belonging to Captain Rodgers "Mounted Volunteers." We also noted one other invoice, dated October 1861, which places the Rangers at Camp Big Spring. In any case, the Rangers' relations with the U.S. Army in general, and "Buffalo Soldiers" in particular, were not very amicable (e.g., Dobie 1989; Fehrenbach 1968). Finally, it would appear that there is no substance to the reports that place the Rangers at "Camp Elizabeth."

\section{Military Posts and Outposts}

\section{Fort Chadbourne}

Fort Chadbourne (1852-1861/1867) was established on Oak Creek, a tributary of the Colorado River, on the October 21, 1852, by Companies A and K, 8th Infantry, of Camp Johnston on the Concho. This fort was abandoned by the U.S. Army on March 1861, and turned over to Confederate troops. It was not reoccupied until June 1867 by Companies A, D, G, and M, 4th Cavalry (four officers and 143 enlisted men). Ft. Concho maintained a "Permanent Camp" (one officer and 50 enlisted men) on the main fork of the Rio Concho for "looking out for Indians." Ft. Chadbourne received a letter on August 15, 1867, "directing a careful examination of the country in the vicinity, with a view to changing the Post." On November 5, 1867, two non-commissioned officers and 15 privates escorted a cavalry officer to the Rio Concho to meet Board of Officers determining the permanent location of the new post. This was easily done, with the site chosen being at the fork of the two Conchos. 


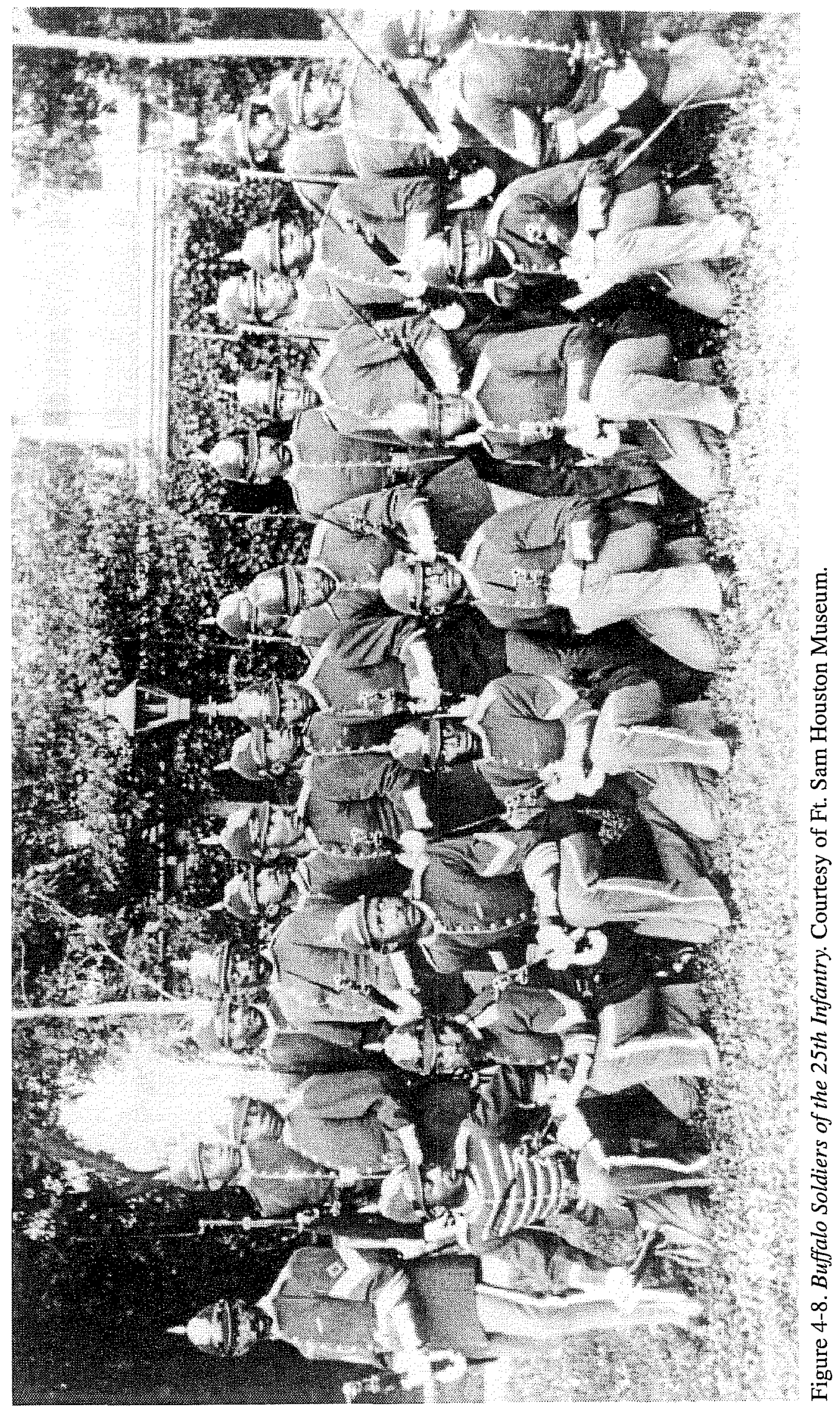




\section{Fort Concho}

Fort Concho (1867-1889), one of the last three frontier forts constructed, was established on December 4, 1867 as Camp Hatch. The name of the camp was changed to Camp Kelley in January 1868 and to Ft. Concho on March 1868. Ft. Concho was located at the junction of the Main Concho and the North Concho rivers. As was the case for the troops stationed at Ft. Chadbourne, the soldiers at Ft. Concho were responsible for scouting the area for signs of Indians, as well as escorting the mail and cattle drives. Throughout the history of the post, very few encounters with Indians were experienced. Signs and reports of Indians were often pursued with little success.

\section{Camp Elizabeth}

Camp Elizabeth never existed, at least not according to any known "official" records and/or post returns. The only reference to "Camp Elizabeth" is found in Dearen (1993), but his account relies heavily on folklore. Historically, it was referred to solely as the subpost at the "Head of the North Concho," and was garrisoned for a relatively brief period-March 1880 to October 1882. The first official mention of Ft. Concho's subposts occurs January 1871, which notes the "Monthly relieving of detachments stationed at Head of the Concho, Johnson's Station, and Camp Charlotte." These are nowhere near the Camp Elizabeth site. The subpost at the Head of the Concho has often been confused with the one at the Head of the North Concho. The former was located some 40 miles west of Ft. Concho along the Main Concho River, while the latter was located some 60 miles northwest, along the North Concho River. The subpost at the Head of the Concho functioned between July 1869 and November 1878. Interestingly, between 1869 and 1878 , the number of men assigned to the Head of the Concho and the other two sub-posts was minimal; no more than five men at any one time. A full garrison was not stationed at any of Ft. Concho's subposts until the early-1880s. The subpost at the Head of the North Concho was first garrisoned by Company $M, 10$ th Cavalry, with three officers and 68 enlisted men.
During most of its two-year history, Camp Elizabeth was garrisoned by Company M, 10th Cavalry (Buffalo Soldiers). On at least one occasion, March to May 1881 , the subpost was garrisoned by a combination of troops of Company D, 10th Cavalry, and Company F, 16th Infantry. During the last two months of its existence (September and October 1882), the subpost was garrisoned by Company C, 16th Infantry. Finally, because of potential confusion between the Camp at the Head of the Concho and the Camp at the Head of the North Concho, and in deference to local folklore, we suggest that the site continue to be referred to as Camp Elizabeth.

\section{Buffalo Soldiers}

The history of the Buffalo Soldiers at Ft. Concho began in mid-March 1869 with the arrival of the 9th Cavalry and the 41st Infantry. Between April 1869 and May 1870 , the entire complement of enlisted men at Ft. Concho was comprised of Buffalo Soldiers: 9th Cavalry and 41st Infantry, April 1869 to October 1869; 9th Cavalry, 24th Infantry, 38th Infantry, and 41st Infantry, November 1869; and 9th Cavalry and 24th Infantry, December 1869 to May 1870. The 9th Cavalry was reassigned to another post between June 1870 and June 1871, and then returned to Ft. Concho in June 1871. In May 1873, the 9th Cavalry was joined by troops of the 10 th Cavalry. The 9 th Cavalry was reassigned to New Mexico in January 1875.

Colonel Benjamin Grierson, 10th Cavalry, was in command of the post between April 1875 and July 1882. For a period of three years, the entire complement of enlisted men at Ft. Concho was attached to one of the Buffalo Soldier regiments: the 10th Cavalry and 25th Infantry, August 1877 to May 1880; and the 10th Cavalry and 24th Infantry, June 1880 to November 1880 . Command, or headquarters, of the 10th Cavalry was transferred to Ft. Davis in July 1882. Elements of the 10th Cavalry, and occasionally of the 24th and 25th Infantry, remained at the post until March 1885. In March 1885, the entire complement of the 10th Cavalry stationed in Texas left for the Department of Arizona. The 9th and 10th Cavalry continued to distinguish themselves in New Mexico, Arizona, the "Badlands," and Cuba. 


\title{
Chapter 5: Archaeological Investigations
}

\author{
Maureen Brown, Bruce K. Moses, and José E. Zapata
}

\section{Archaeological Field Methods}

Maureen Brown and Bruce Moses

\section{Phase I Field Methods}

The goals of Phase I archaeological field investigations at Camp Elizabeth (41ST111) were to obtain a representative sample of the artifactual material; to investigate further Features $1-5$, which had been previously identified during TxDOT's surface and metal detector survey (Kenmotsu et al. 1997); and to create an improved base map of the area.

From July 23-29, 1997, field activities included establishing, excavating, and mapping a $30-\mathrm{ft}$ interval grid within the TxDOT expansion along U.S. 87 (Figure 5-1). The grid measured $600 \mathrm{ft}$ east-west and ranged from 60-120 ft north-south. The northern grid boundary paralleled the right-of-way fence line, and incorporated TxDOT Features 2-5. A primary datum was established using TxDOT's temporary datum, which was a post on the right-of-way fence. Initially, compasses and two 100-ft tapes were used to map the area under investigation.

Pin flags and flagging tape were used to lay out 72 20-x-20-inch units (U1-U72) in the northeast corner of each 30-x-30-ft square within the grid (Figure 5-1). The units were initially to be placed in the southwest corner, but the southern grid boundary was approximately $10 \mathrm{ft}$ north of U.S. 87 in an area that was highly disturbed by highway construction and would have jeopardized the safety of the crew members. The row of units located within the southern grid boundary were excavated from 5-10 ft south of the northeast corner because an elevated fire berm was located in this area (Figure 5-2). The units were hand excavated using trowels and sharpshooter shovels to a depth of six inches below the surface to determine whether there were subsurface artifactual remains or features.

Additional work was aimed at investigating the architectural integrity and cultural use of a possible farrier's shop, which was located, mapped on the surface, and designated Feature 1 by TxDOT (Kenmotsu et al. 1997). TxDOT's map of Feature 1 showed a concentration of irregular and cut limestone blocks on the surface. Because high grasses had grown up over the feature, TxDOT's Sterling City office kindly brought out a weed eater to cut the grasses to the level of the surface stones. Once the high grass was cut, CAR staff used pins to probe just beneath the surface in and around Feature 1 to determine the presence, size, and depth of the stones. Four 20-x-20inch units, numbered U73-U76, were hand excavated in and around Feature 1. Each unit was placed to locate the subsurface structural remains, in any, of the foundation and to recover both temporally diagnostic artifacts and artifacts related to the function of Feature 1. Units were hand excavated with trowels and sharpshooter shovels. U73 was placed to confirm the presence of the northwest corner of Feature 1, since the north and west limestone foundation walls were partially visible on the surface. U74 was placed in an area to test the possible location of the south wall foundation. U75 was placed inside the north wall of Feature 1 to test the floor area for possible cultural remains of associated activities. The presence of such an artifact assemblage would possibly yield information on the function of the interior of Feature 1. U76 was placed in an area to try to locate the southeast corner of Feature 1. At the completion of the excavation of U73-U76, a detailed map was drawn of Feature 1.

All 76 units were excavated to a depth of at least 6 inches or until the matrix was culturally sterile. Soil from the units was screened through $1 / 4$-inch wire mesh. Site field notes were kept by the project director and 


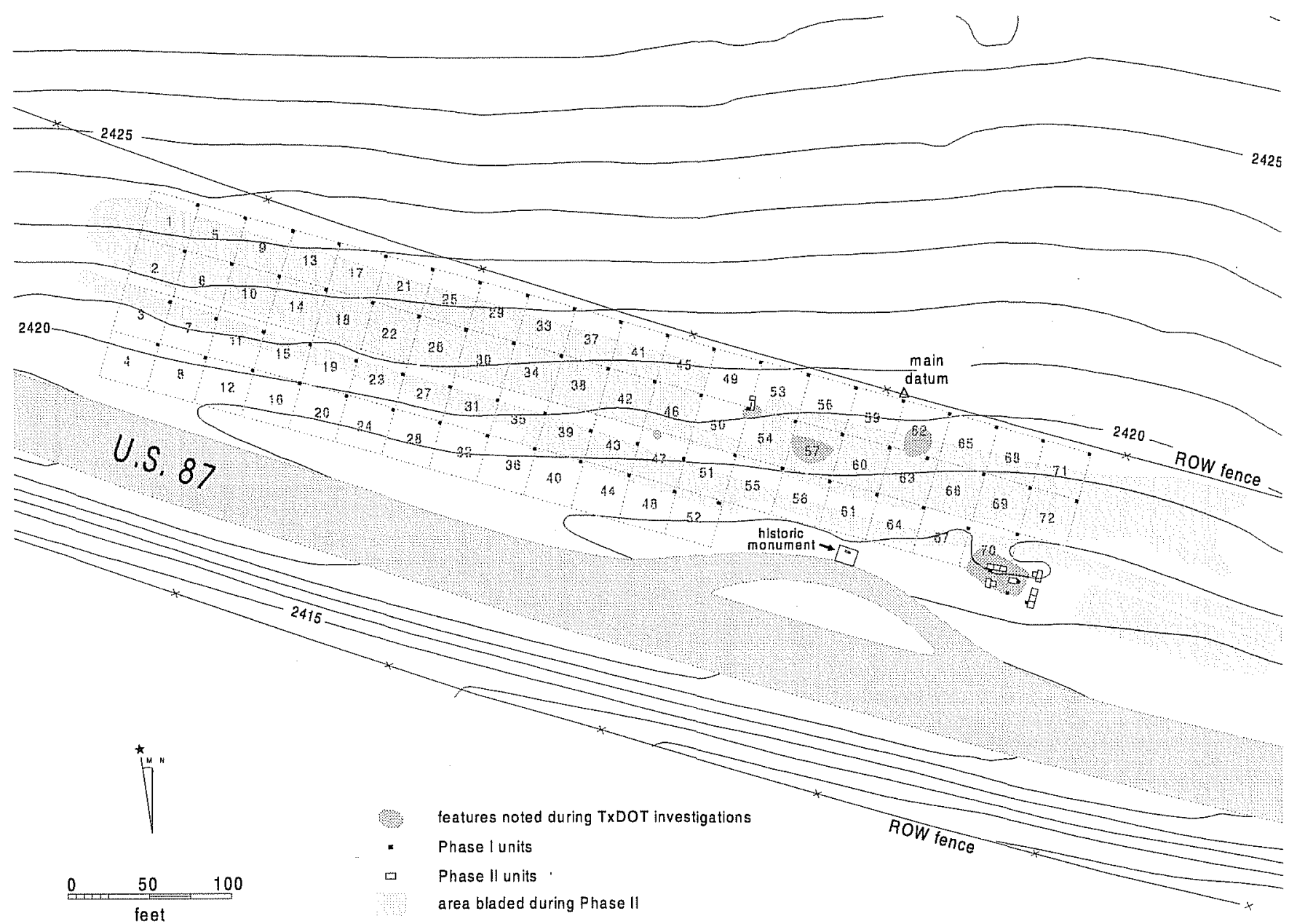

Figure 5-1. Site map showing grid in 41 ST111 project area, TXDOT previous investigations, CAR's Phase I and II investigations. 
standard CAR unit-level forms were completed for each excavated unit. Soil samples were collected from units and levels when deemed necessary. All cultural material from the units and surface finds were recorded, collected in plastic and paper bags, and brought to the CAR laboratory for processing and analysis. Archaeological investigations were documented with color slide and print film, and a photo log was completed for each roll.

Additionally, CAR archaeological staff received permission from the adjacent landowner and caretaker to go on their property and photo-document and map the associated Camp Elizabeth architectural features that were visible on the surface. Most of the features had originally been illustrated in Daniels (1976) (see Figure 2-3). Preliminary drawings of the limestone block concentrations and the artifact concentrations were completed using a 100-ft tape and compass. Photographs were taken, and artifact concentrations and types were noted in the field records. The caretaker then took us to where two soldiers may have been buried, as evident from two clusters of piled up limestone slabs. A sketch was completed with a tape and compass and photographs were taken.

\section{Phase II Field Methods}

Based on preliminary observations from Phase I fieldwork, TxDOT staff suggested that additional archaeological field investigations be carried out at 41ST111. Phase II fieldwork was conducted from August 12-16, 1997. This phase was undertaken to investigate further the remains of Features 1 and 4, to monitor removal of the top surface matrix of the site with a Gradall to see if any subsurface artifactual remains or features of the camp existed, and to complete a site field plan map with the Total Data Station (TDS).

Eleven units (U77-U86, and U89) were placed in and around Feature 1 to further investigate the architectural integrity and cultural use of the limestone foundation (Figure 5-2). The units were hand-excavated using trowels and sharpshooters. The horizontal excavation of the units measured from two to three feet wide to try to recover the entire width of the limestone foundation. Likewise the units varied in length from 3 to 7 feet to follow the limestone walls. The units within Feature 1 were excavated to 6 inches below the surface (bs). After the units were excavated, a plan map of Feature 1 was completed.

CAR staff placed two units (U87 and U88) within Feature 4 (Figure 5-2). TxDOT's archaeological staff had initially identified and recorded Feature 4 and had detected subsurface readings using a metal detector. On the surface, Feature 4 appeared a as a light scattering of limestone rocks. The units were excavated to determine if there were subsurface features, structural remains, or artifacts. U87 measured $3 \times 6 \mathrm{ft}$, and U88 measured $2 \times 6 \mathrm{ft}$. Both U87 and U88 were excavated to a depth of 6 inches below the surface.

Excavated units within Features 1 and 4 were documented using standard CAR unit-level forms. All excavated soil was sifted through a 1/4-inch wire mesh screen. Artifacts and samples from Features 1 and 4 were collected in field bags with labels. Features were also photo documented using color film that was processed into slides and negatives. Upon completion of the fieldwork artifacts were transported to CAR's laboratory for processing.

Further investigations included blading the remaining sections within the established grid to locate any subsurface remains of Camp Elizabeth. Several areas were bladed from the surface to approximately three inches below the surface (Figure 5-1). Investigations first attempted to grade the surface with a Gradall on loan from the TxDOT San Angelo Office. However, because the removal of the top soil with the Gradall was very time consuming because it had a short blade and it excavated in a circular fashion, it was decided instead to use a maintainer with a straight 14-ft blade that could move faster across the surface. The TxDOT Sterling City staff operated the maintainer while the project archaeologist monitored the excavation of the top soil for subsurface cultural artifacts and features. The soil was excavated to an approximate depth of three inches below the surface. Visible artifacts and anomalies (i.e. oxidized or discolored soil, gravel concentrations, ashy soil, artifact concentrations, etc.) were flagged with pin flags and marked according to 


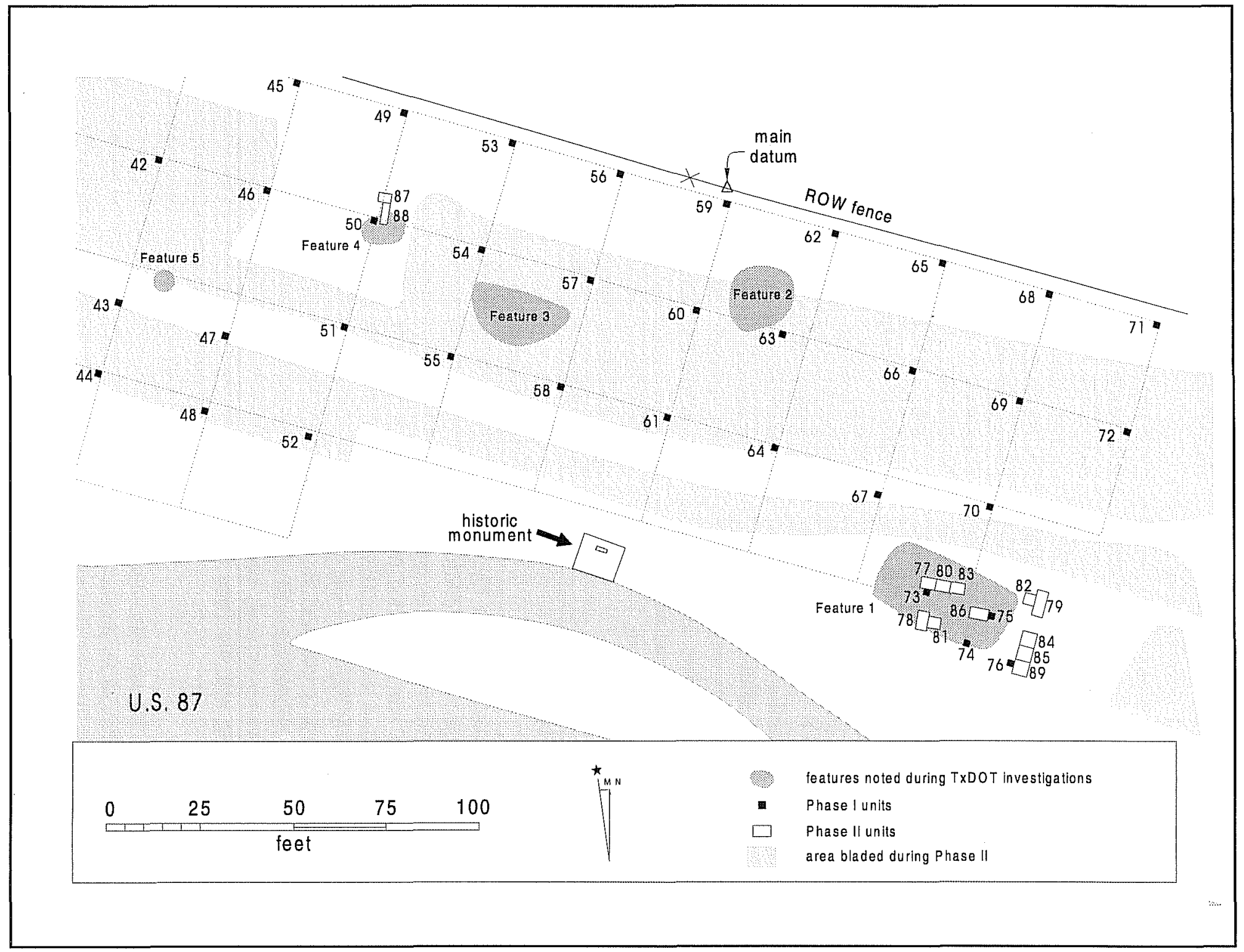

Figure 5-2. Site map showing TxDOTs identified Features 1-5 and CAR's excavated units within Features 1 (U77-86, and U89) and Feature 4 (U87-88). 
artifact type or given an anomaly number (e.g., A1A70). Additionally, each anomaly was recorded and mapped in situ with the TDS. Representative anomaly samples were mapped in more detail and photographed, but not excavated. Artifacts and matrix samples from these areas were collected, bagged, and brought back to CAR for processing.

\section{Field Mapping Methods}

A Sokkia Set 5 TDS and a SDR33 data collector were used to map the site's features and produce a detailed topographic map of the site. The temporary datum established by TxDOT during their initial survey of the site in the spring of 1997 was relocated and used as the principle datum for the project. Additional traverse points were set across the site in order to record the topography of the immediate area. Unit datums and individual unit corners were located during the preliminary traverse, and precise coordinates and elevations were assigned to them at that time.

Where the terrain was relatively constant and unbroken, shots were taken at consistent intervals not exceeding $50 \mathrm{ft}$. Where the local relief varied more than 6 inches, shots were taken to demonstrate the topographic change. This was generally confined to areas adjacent to or containing structures, walls, and other modified terrain: In addition to the collection of topographic data, a 100-percent surface coverage of artifacts and soil anomalies was undertaken within the bladed area. The utilization of these conventions ensured that the survey retained a high degree of detail while allowing it to proceed at a relatively fast pace.

The resultant data collected as a result of the Camp Elizabeth survey were downloaded from the data collector into a laptop at CAR in the form of a text file. This was then opened in Surfer and a threedimensional image of the site was created. These data was also used to produce density and presence/absence maps for the bladed areas.

\section{Laboratory Methods}

Immediately after the completion of the archaeological field investigations, recovered artifacts were transported to the CAR laboratory facility for processing. This included washing, air drying, sorting by artifact type (i.e., metal, glass, ceramic), labeling using acid-free paper tags, and cataloging the artifacts. The artifacts were cataloged using standard CAR catalog forms for historic and prehistoric remains. After the artifacts were labeled and cataloged they were placed in acid-free boxes with acid-free box labels attached. These methods were in keeping with the standards for curation at the Fort Concho curation facility. At the completion of the analysis phase of the project, all artifacts, soil samples, and records related to 41ST111 were transferred to the curator of artifacts at Fort Concho, San Angelo, Texas, where they were permanently curated.

\section{Artifact Analysis Methods}

Prehistoric artifact types include lithic remains such as chert debitage and tools. Historic artifact types include items related to the camp like ceramic, glass, nails, buttons, metal scrap, horseshoes, and bone. Artifact types were further sorted and analyzed according to functional category. Several categories were created for assignment of the recovered artifacts: Lithics, Activities, Construction, Domestic, Faunal, Miscellaneous, Personal, and Workshop. The analytical framework used for the examination of recovered material from this investigation was modeled after South's (1977) artifact pattern analysis method. In addition, Largent's (1996) adapted version of this pattern, used to analyze remains from Fort Sill military post, was utilized.

The lithic category designation included chert debitage and flakes. The other categories were comprised of historic artifacts. The domestic grouping included household items, such as those related to the preparation, serving, consumption, and storage of food or drink (bottle and drinking glass, ceramics, utensils, pots, etc.). The faunal category included animal bone fragments. The activities grouping consisted of nonhousehold items, such as firearms and toys. The 
construction category referred to items related to architecture and building remains (i.e., nails, brick, mortar, plaster, window glass, etc.). The personal category was created for items of individual use such as clothing and buttons. The workshop grouping included artifacts related to working in a shop (i.e., tools, horseshoes, horseshoe nails, iron cuttings, etc.). The miscellaneous category was created for items that may be classified in more than one grouping, or an unidentifiable category (i.e., charcoal, unidentifiable metal fragments, mussel shell, etc.).

The artifact data was entered into an Excel spreadsheet program to facilitate the artifact analysis and to artifact presence/absence and density maps of the site with Surfer. Diagnostic artifacts were used to generate an approximate occupation date of the site which was compared to the archival data. There was no attempt to look at date ranges for the different areas of the site due to the small sample recovered.

\section{Results of the Archaeological Investigations}

\section{Maureen Brown}

For discussion, the results of CAR's archaeological investigations conducted at Camp Elizabeth (41ST111) are divided according to the various areas excavated within the limits of the project boundaries: excavations of 72 20-x-20-inch units (U1-U72); excavations in and around Features 1-5; and excavations of the bladed areas to ca. three inches below surface (Figures 5-1 and 5-2) and recording of anomalies (A1-A70) within this area. This section also includes artifact descriptions. Results from surface recording and mapping of several features in the adjacent private property are included as a separate section.

\section{Units 1-72}

Investigations included the systematic excavations of $\mathrm{U} 1-\mathrm{U} 72$ within the $30-\mathrm{x}-30$-ft interval grid (Figure 51). U1-U72 encompassed the area of the supposed camp grounds of the enlisted men. Surface visibility was fair to poor with high grasses and scattered mesquite shrub brush. The soil in most of the units consisted of a thin, dark humus layer to ca. 1.5 inches below surface (bs); and a dry, fine, very compact to moderately compact, light brown sandy loam, and intermixed with few (ca. less than five percent) small limestone cobbles, from ca. 1.5-4 inches bs. From ca. 4-6 inches bs, the soil was a slightly darker brown and generally less compact. However, several units (U4-U32) excavated along the southern grid boundary, closest to U.S. 87 roadway (Figure 5-1), contained disturbed road gravel material. The material consisted of precoated, pea-size gravel mixed with limestone cobbles (ca. 1-6 inches in diameter) and chunks of asphalt. In addition, two units contained remains that suggests the previous right-of-way fence line was in this general vicinity. U16 contained two fragments of barbed wire, and three rusted fencing staples were found but not collected in U36.

The excavations yielded intact cultural material in 35 (48.6 percent) of the 72 units. Both prehistoric and historic period artifacts were included in the artifact assemblage present within the grid. Lithic artifacts were the only prehistoric remains and consisted of nondiagnostic chert debitage and chunks. Historic period artifacts within these units included construction artifacts (cut nails, window glass), workshop (horseshoe nails), domestic (bottle glass, ceramic), faunal, personal (buttons), and miscellaneous (mussel shell, charcoal). A catalog of artifacts recovered from the project area listed by provenience is given in Appendix B. A specific analysis of the spatial arrangement of the artifacts by category is presented in Chapter 6.

The western half (U1-U40) of the project area was noticeably lacking in historic cultural material. Of these 40 units, 21 (52. 5 percent) contained artifacts. Thirteen (62 percent) of the 21 units contained evidence of possible prehistoric remains. Only four units in the west half contained historic material, three units yielded evidence of both historic and prehistoric, and one unit had faunal remains that may have been from either period. The eastern half of the investigated area (U41-U72) contained considerably more historic remains and enveloped Features 2-5, described below. Fourteen of the 32 units ( 44 percent) contained cultural 
material, while 18 (56 percent) were culturally sterile. Of the 14 positive units, 11 (79 percent) yielded historic material, one unit ( 7 percent) contained prehistoric, and two units (14 percent) had both.

\section{Feature 1}

\section{Phase I (U73-U76)}

On the surface, Feature 1 was a large concentration of shaped and unshaped limestone rocks. After the high grass around the feature was removed by TxDOT, the surface limestone became more noticeable. A possible north wall alignment was visible on the surface. Excavation of the initial four 20-x-20-inch units (U73U76) yielded evidence for wall foundations.

U73 confirmed the structural location of the interior northwest corner of Feature 1 beginning at 4-6 inches bs. Bottle glass and metal fragments were recovered from 0-3 inches bs. A hard-packed surface was encountered ca. 3 inches bs. From 3-4 inches bs, the soil consistency was moist and loose, then became more compact again at 4 inches bs. At 6 inches bs, limestone foundations representing the north and west walls were exposed and a complete brown beer bottle was discovered in the southeast corner of the unit (Figure 5-3). Other artifacts at this level included cut nails, metal scrap, and a few animal bone fragments (Appendix B). Excavation of U73 continued below the six-inch limit to expose the foundation and to delineate the depth of cultural remains within Feature 1. From 6-12 inches bs, U73 yielded metal fragments, cut nails, glass, slag, charcoal, and animal bone. From 12-14 inches the matrix was culturally sterile.The entire interior foundation wall profile was exposed to 12 inches bs (Figure 5-4). Results showed the foundation wall was composed of two to three courses of limestone. The pattern of the remaining exposed foundations included wider and larger stones ( 4 inches thick) atop thinner stones ( 2 inches thick), with a basal course of larger stones ( 6 inches thick). The stones appeared to be placed directly into the soil.

Unit 74 was placed to test for the presence of the south wall of Feature 1. No structural evidence or even large foundation stones were present in this unit which was excavated to 6 inches bs. From surface to 5 inches bs the matrix was composed of compact, dry, fine, light- brown, sandy loam, with a few small limestone cobbles. Artifacts consisted of cut metal construction and horseshoe nails, brown bottle glass, and scrap metal. From 5-6 inches bs the matrix changed to a rubble layer of limestone pebbles with a relatively high concentration of charcoal. This was mixed with a higher density of artifacts consisting of horseshoe nails (22), iron cuttings, and metal fragments.

Unit 75 was placed within the supposed interior walls of Feature 1 to look at possible flooring remains or artifact concentrations. Unit 75 was excavated to a depth of 6 inches bs and yielded no patterned structural

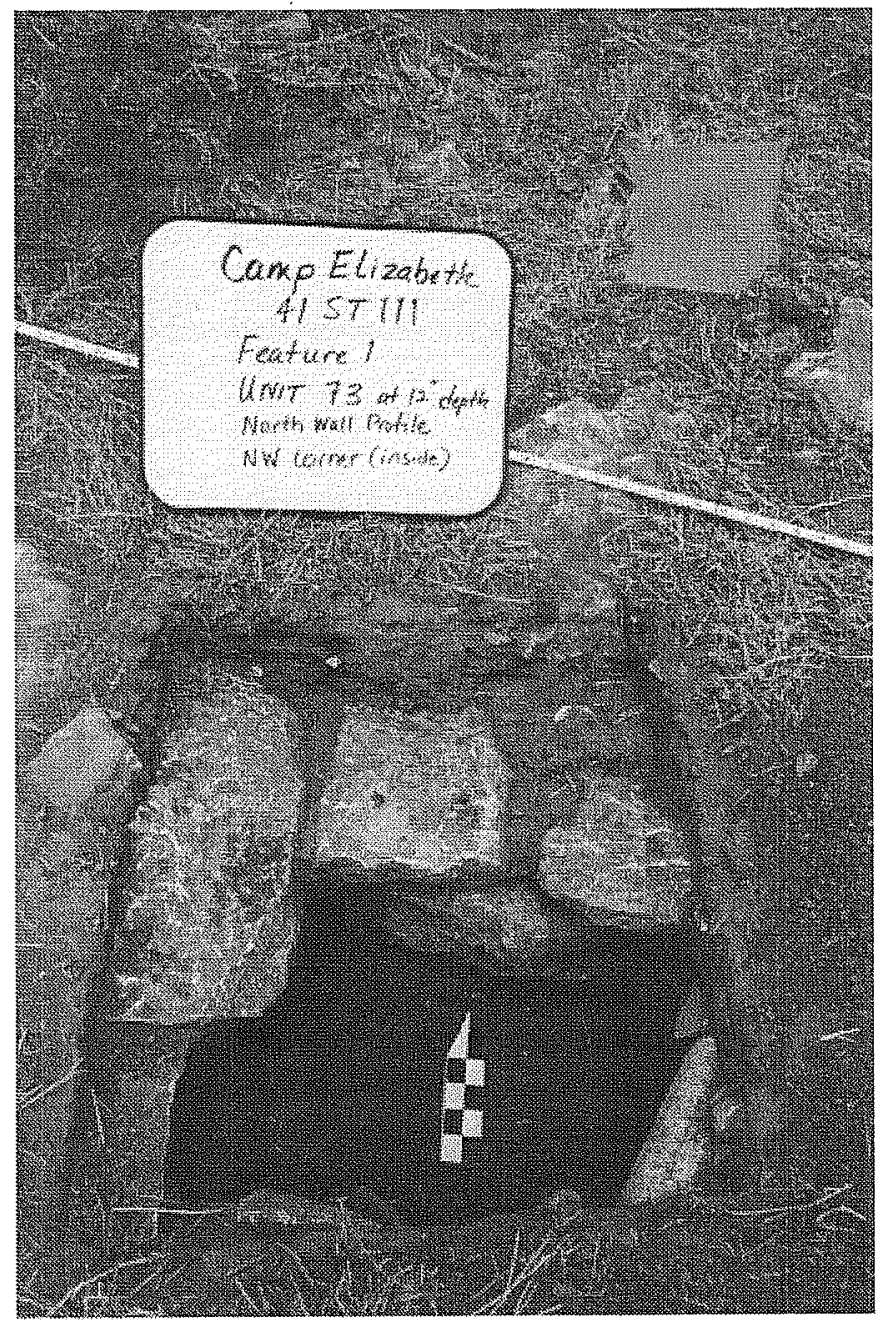

Figure 5-3. Unit 73 (12 inches bs) showing interior northwest corner of Feature 1. 


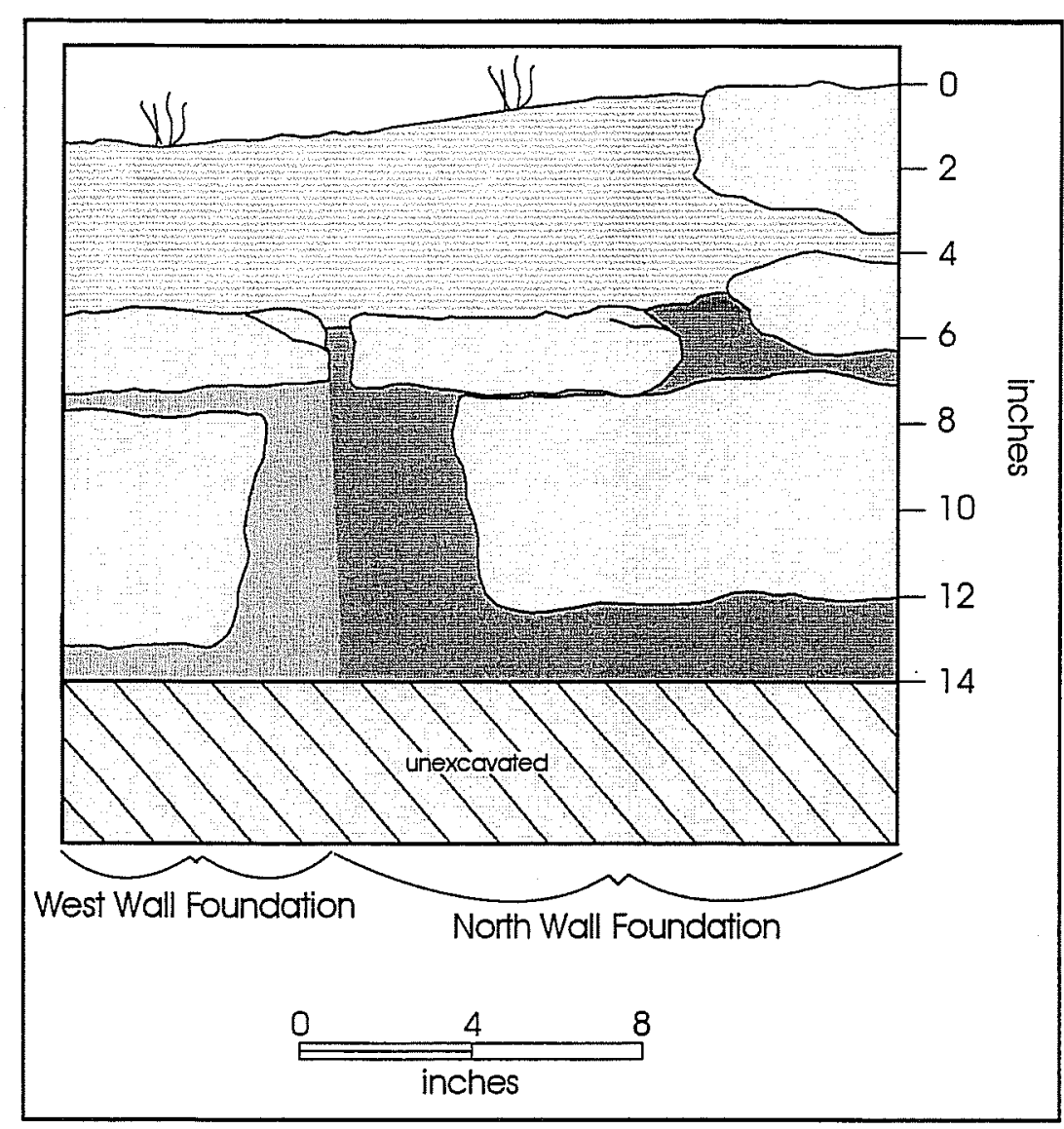

Figure 5-4. Unit 73, profile of north wall of Feature 1 within U73. location, size, and function of Feature 1 (Figure 5-5). Fairly intact remnants of the north, east, and west limestone rock foundation walls were recovered in nine of the 11 units (Figure 5-6). No evidence for a south wall foundation was revealed by the excavations. The dotted line in Figure $5-5$ is speculative.

\section{North Wall Foundation}

Excavations of five units (U77, U79, $\mathrm{U} 80, \mathrm{U} 82$, and U83) revealed evidence for the north wall foundations. The wall consisted of large, roughly shaped and small, unshaped limestone foundation rocks which were encountered ca. 1-2 inches bs. A 17$\mathrm{ft}$ section of the north wall, oriented east-west and measuring ca. $2 \mathrm{ft}$ wide, was exposed (Figure 5-7). In addition, U77, slightly overlapping U73, further delineated the size and integrity of the northwest corner (Figure 5-2). The exterior and interior portion of the northeast corner were encountered in U79 and U82, respectively. remains. From surface to 2 inches bs the matrix consisted of compact, light brown sandy loam. From 2-6 inches bs it was comprised of light scattering of roughly shaped limestone rubble representing wall fall. Artifacts were present from ca. 1.75-4 inches bs and included horseshoe nails, miscellaneous metal fragments, and one piece of mussel shell. Unit 76 was placed within Feature 1 to test for the presence of the southeast corner of the limestone foundations. Excavations from surface to 10 inches bs yielded a few pieces of limestone rubble (10 inches bs) in a lightbrown, sandy loam, but no wall remains. Four artifacts-three horseshoe nails and one fencing staple-were recovered from 3-8 inches bs.

Phase II (U77-86, and U89)

Results from the excavation of 11 variously sized units (U77-U86 and U89) provided further evidence for the

\section{East Wall Foundation}

Portions of the east wall of Feature 1 were exposed in U79, U82, U84, U85, and U89 (Figure 5-5 and Figure 5-8). The stone size and make up of the east wall was similar to the north wall. Excavations of these units exposed approximately $14 \mathrm{ft}$ of the east wall which was oriented north-south and was roughly $2 \mathrm{ft}$ wide.

\section{West Wall Foundation}

Approximately five feet of the west wall foundation were exposed in two sections in excavations of U77 and U78. Within the west wall, a two-foot long, roughly shaped limestone rock was lying on the surface, jutting out from U73 and U77.

\section{Units 77-86, and U89}

U77 excavations included the removal of brown sandy loam and rock rubble to 3 inches bs. Numerous brown bottle glass fragments and one horseshoe nail were recovered from the surface to 3 inches bs. From 3-6 


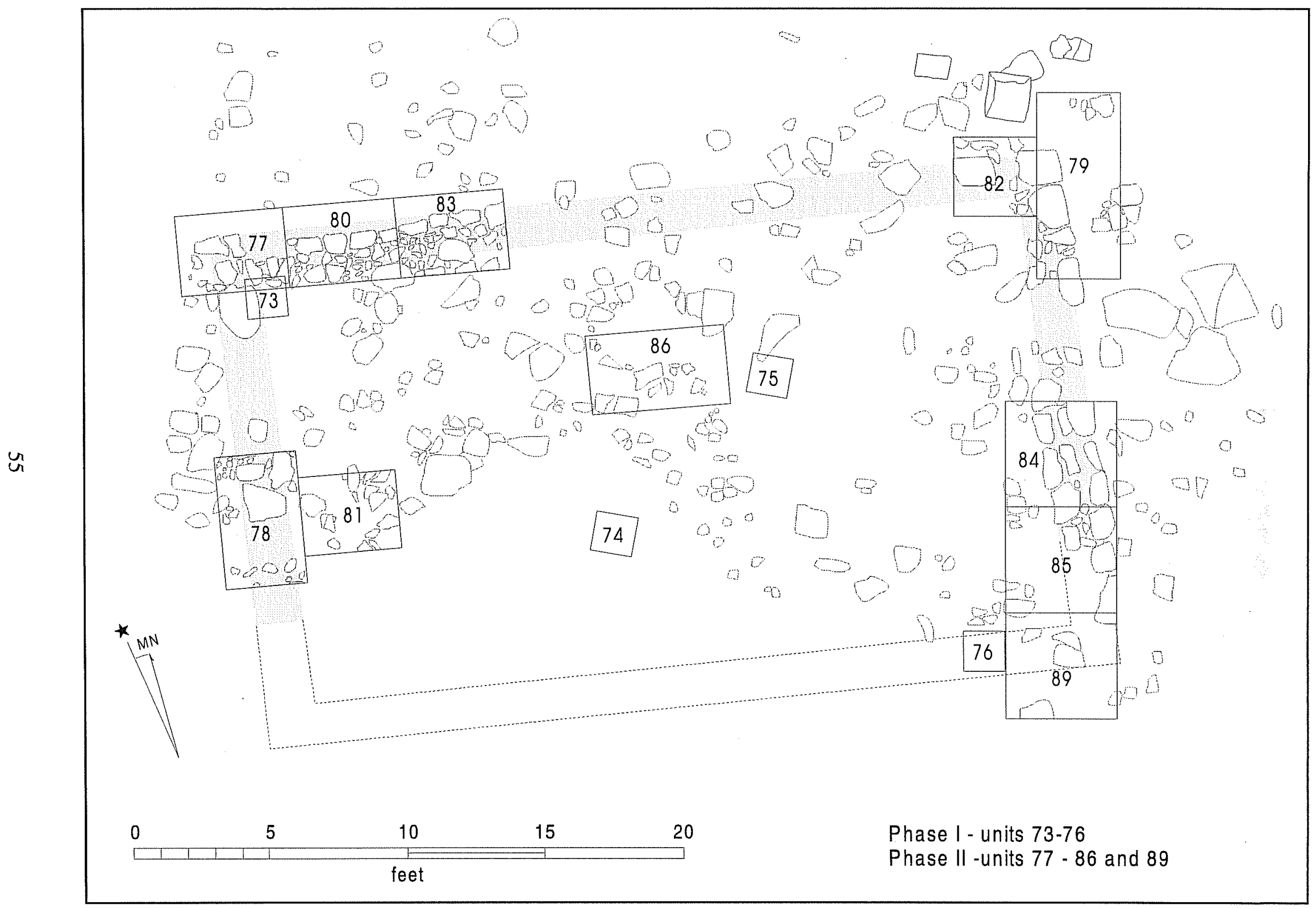

Figure 5-5. Feature 1, plan map showing structural limestone rock foundation remains recovered within excavated units (U73-86 and U89). 


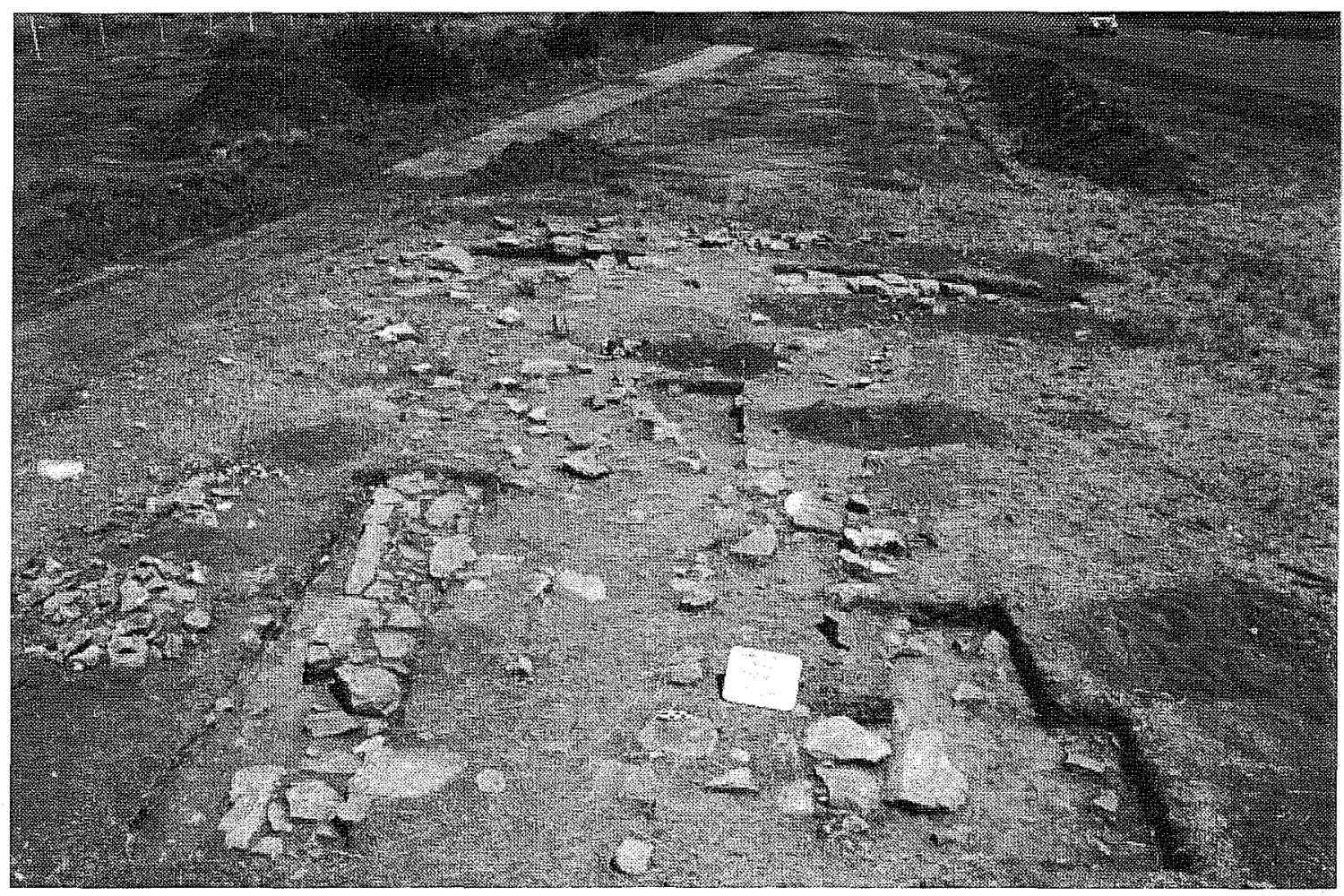

Figure 5-6. Feature 1 after excavations (looking east). The west wall is in the foreground and the north wall is on the left.

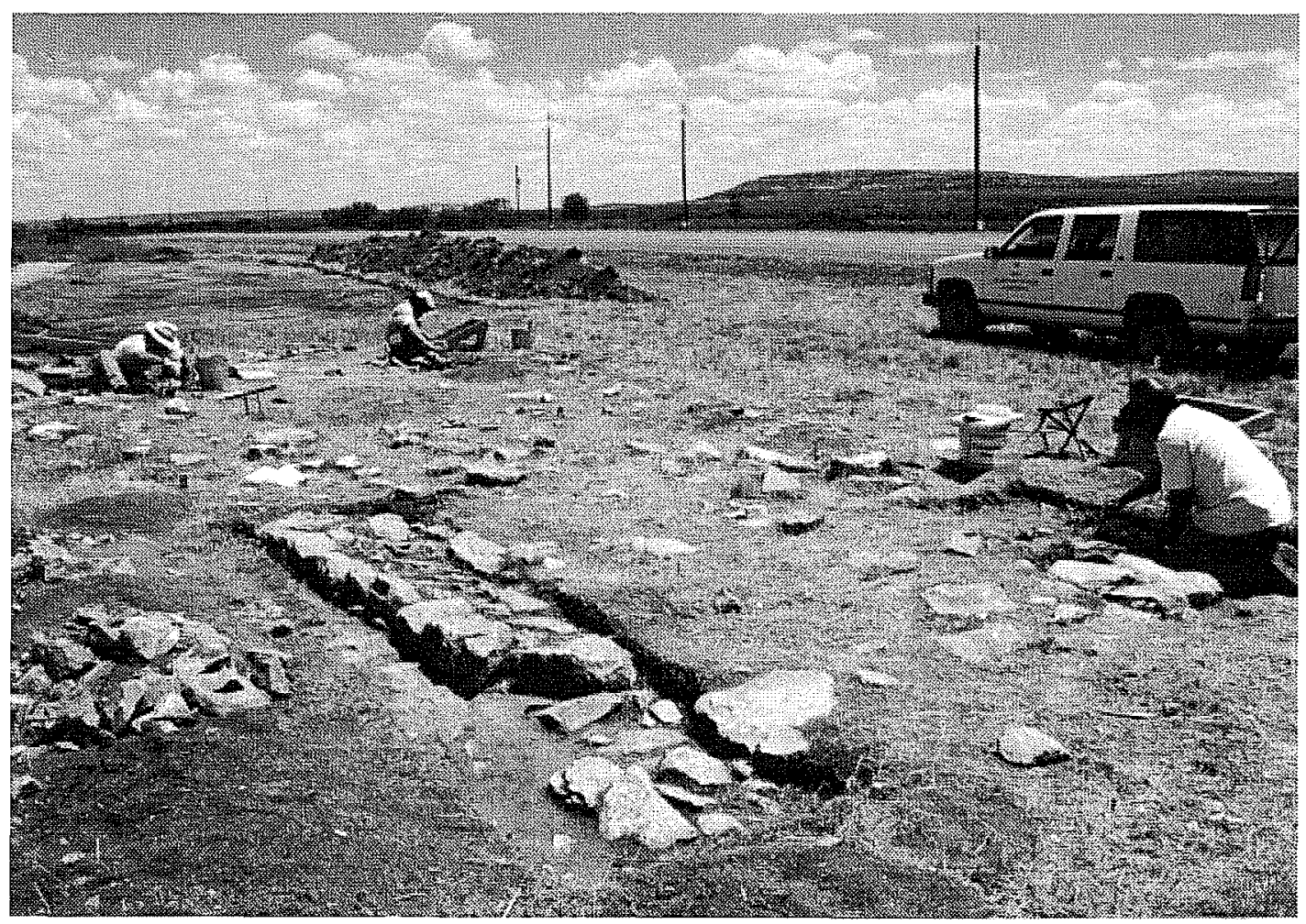

Figure 5-7. Feature 1, exposure of north and west walls (looking southeast). 


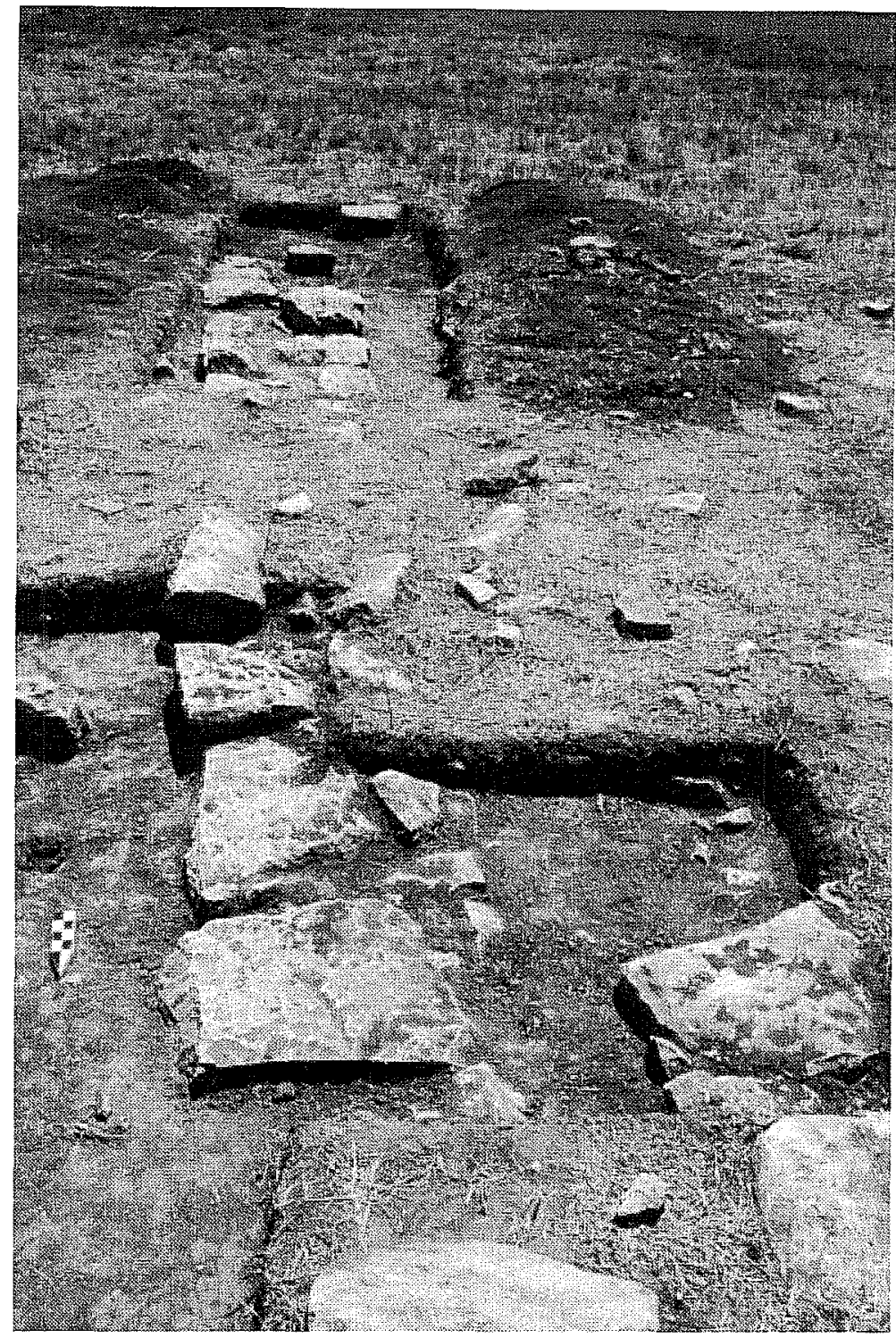

Figure 5-8. Feature 1, exposure of the east wall and the northeast corner (looking south).

inches bs, the rubble was removed, and the north wall limestone foundations and northwest corner were exposed. Artifacts at this level were concentrated within the southwest quadrant of U77, outside the northwest corner of the structure. These included additional bottle glass fragments, horseshoe nails, charcoal, a cut nail, and an iron cutting (Appendix B).

U78 excavations exposed about $2.5 \mathrm{ft}$ of the west wall foundation. The soil was a brown sandy loam mixed with small clusters of charcoal fragments scattered about the unit. From 3-6 inches bs was an abundance of slag nodules (ca. 44 total), brown bottle glass fragments (ca. 25 total), and cut square nails fragments (ca. 24 total). Small amounts of other workshop, construction, domestic, and faunal remains were also found (Appendix B).

U79 uncovered the exterior portion of the northeast corner and revealed a ca. $5-\mathrm{ft}$ section of the east wall (Figures 5-5 and 58 ). The exterior edges of the limestone rock foundations were placed to form a straight wall alignment. Although U79 $(3 \times 7 \mathrm{ft})$ was a comparatively large unit, very few artifacts were found. These included nine fragments of clear glass, presumably from the same bottle. Interestingly, along with metal fragments, three lithic flakes, and a bone fragment from a large jack rabbit were found in U79.

U80 exposed a $2-\mathrm{x}-4$ - $\mathrm{ft}$ section of the north wall at ca. one inch bs. From the surface to 3 inches bs in the northern quarter of U80 (outside the north wall), the soil consisted of a brown sandy loam. This matrix was mixed with a large concentration of brown bottle glass fragments and small amounts of metal fragments, charcoal, horseshoe nails, an iron cutting, and slag (Appendix B). A loamy caliche-like surface with very few bottle glass fragments was encountered from 3-6 inches bs.

In U81, located inside the west wall to the east of U78, excavations did not recover Feature 1 foundation remains. Limestone rocks were recovered, but they showed no evidence of patterning. Artifacts were concentrated in the northwest corner of the unit, primarily from the 3.5-5 inch level. Specks of charcoal were found at this level throughout the unit. Artifacts included slag nodules, cut square nails, fencing staples, window glass fragments, aqua and brown bottle glass fragments, fragments of a tin can, miscellaneous metal fragments, horseshoe nails, an iron cutting, and a complete horseshoe. The horseshoe was found at ca. 5.5 inches bs within the northwest quadrant of the unit. 
U82 excavation revealed a poorly defined interior portion of the northeast corner. The limestone rock foundation was present, but stones were either missing or slightly out of alignment (Figure 5-5 and Figure 58). Few artifacts-a nail and wire fragments - were present within the six inches excavated.

U83 exposed another 2-x-4-ft section of the north wall, incorporating both the interior and exterior edges (Figure 5-5). Only a few artifacts were found within U83, all undiagnostic metal fragments.

U84 revealed a 2-ft-wide, intact, 4 -ft long section of the east wall foundation of Feature 1 (Figure 5-5). Both the interior and exterior edges of this wall were uncovered, exposing an evenly aligned wall oriented north-south. Excavation within the northern half of U84 recovered a few artifacts, mainly glass and a fair amount of animal bone, at ca. 3 inches bs. Faunal remains consisted of 10 bone fragments, possibly representing cattle remains, and one turtle shell fragment. The southern half of the unit, from 3-6 inches bs, especially inside the east wall, contained evidence of oxidized material. The matrix consisted of a large amount of charcoal mixed with a few horseshoe and cut nails, and a fragmented horseshoe.

U85 was located south of U84. Excavations of this unit exposed another ca. $4 \mathrm{ft}$ section of the exterior east wall. Portions of the interior east wall stones (ca. $2 \mathrm{ft}$ ) were missing or out of alignment. Only a few artifacts-cut nails and a lead fragment-were recovered from 3-6 inches bs.

U86 was placed in the middle of Feature 1 to locate a possible dividing or center wall foundation. No wall foundations were found within the unit, only limestone rubble. However, artifacts were recovered from ca. 2-6 inches bs. A fairly large amount of miscellaneous metal fragments, an unidentified metal hinge fragment, horseshoe nails, and iron cuttings were recovered from the unit.

U89 was excavated to the south of U85 in hopes of finding the southeast corner of Feature 1. However, excavation of this unit revealed no evidence of a comer or definite wall remains. From the surface to 3 inches bs artifacts included a horseshoe nail, a possible cast iron pot lid fragment, and a bluish glass electrical insulator base fragment. From 3-5 inches bs the soil was very loose and rich with a humus-like consistency. A few artifacts - tin can, metal fragments, and nailswere recovered from level in the northern section of the unit, north of the two limestone rocks (shown adjacent to one another in U89, Figure 5-5). The southern half of the unit contained no artifacts. Pea size and larger gravels were recovered from 3-6 inches bs, possibly related to U.S. 87 construction.

\section{Features 2-5}

Eight 20-x-20-inch units (U43, U50, U54, U55, U57, U58, U60, and U63), one 3-x-6-ft unit (U87), and one $2-\mathrm{x}-6-\mathrm{ft}$ unit (U88) were excavated in and around TxDOT's Features 2-5 (Figure 5-2). The results of CAR's subsurface sampling of these features follow.

\section{Feature 2}

According to CAR's mapping, U60 and U63 were excavated in proximity to the southern portions of TxDOT's identified Feature 2. U60 was west of the southwestern edge, and U63 was just east of the southeastern boundary. U60 excavations revealed that from the surface to ca. 3-4 inches bs, the soil was similar to the other excavated areas-a dry, fine, light brown sandy loam intermixed with a fairly dense layer (30-35 percent) of limestone pebbles. From 3-6 inches bs, the limestone was slightly less dense. Eight artifacts were found in U60. Two metal fragments and a mussel shell fragment were recovered at one inch bs. From 3-3.5 inches bs, a cut nail, lithic flake fragments, and charcoal were found. From 6 inches bs another piece of mussel shell and a faunal (mammal) bone fragment were recovered (Appendix B). U63 contained light brown sandy loam and no cultural material. Cultural material was concentrated toward the southwestern periphery of Feature 2. No structural remains were located. 
Feature 3

U54, U55, U57, and U58 were excavated around the north, south, east, and west boundaries of Feature 3 (Figure 5-2). U54 contained compact light brown sandy loam from the surface to 6 inches bs. Cut nails and a fairly dense layer of charcoal were recovered from 2-3 inches bs. From 3-4 inches bs, fragments of a clear drinking vessel were recovered. From 4-6 inches bs the unit was culturally sterile. U55 contained extremely hard compact soil from the surface to ca. 5 inches bs. From 5-6 inches bs the soil was less compact. Brown bottle glass fragments were found from ca. 2-4 inches bs. U57 contained a moderately compact, light-brown, sandy loam with less than five percent gravels and no cultural remains from the surface to 6 inches bs. In U58, cut nails were found ca. 3-3.5 inches bs, and the soil was similar to U57. These four 20-x-20-inch units indicate that subsurface remains from Feature 3 were more concentrated in the western, and especially the northwestern, boundaries, as evident from U54.

\section{Feature 4}

On the surface, Feature 4 appeared as a scatter of limestone rocks, ca. 4-6 inches in diameter, 0.5-1.5 inches thick, in no apparent pattern. U50 ( $20 \times 20$ inches), U87 ( $3 \times 6 \mathrm{ft})$, and U88 ( $2 \times 6 \mathrm{ft})$ confirmed subsurface cultural remains but found no evidence of a structural feature. U50 was located within the northwestern edge of Feature 4. The unit contained the standard light brown sandy loam matrix intermixed with a few limestone rocks measuring ca. $.5-2.5$ inches in diameter. From the surface to 2 inches bs, cut nails were recovered, and, from 2-6 inches bs, U50 was culturally sterile. During Phase II fieldwork, two larger units were excavated within the northern perimeter of Feature 4, yielding a variety of cultural remains (Figure 5-2). U87 and U88 encountered a light brown sandy loam from the surface to 6 inches bs. A harder, more compact surface was evident at ca. 3-4 inches bs. No evidence of subsurface limestone rocks or structural remains was found. U87 contained artifacts from ca. $2-4$ inches bs. These artifacts included a metal military button with an eagle on the front, the handle of a miniature sword representing a cavalry insignia, a whole bullet and cartridge found in two pieces with powder still evident inside, a possible polish or snuff can, a clear glass fragment, cut nails, and an iron fragment with a rivet. Additional details about these artifacts are included in the artifact descriptions below and in Appendix B. No artifacts were recovered from ca. 4-6 inches bs. U88 contained fewer artifacts with less variety than U87. Artifacts included a chain link fragment, cut nails, window glass, clear bottle glass, and a small undiagnostic lithic flake, from ca. $2-4$ inches bs

\section{Feature 5}

On the surface, Feature 5 appeared to be one 9-x-11-inch limestone rock. Two 20-x-20-inch units (U43 and U47) were excavated to the southwest and southeast of this rock. The soil in both units was consistent with the area. From surface to 6 inches bs, a dry, fine, light-brown sandy loam was present. U43 contained no cultural material, while U47 yielded cut nails and lithic flakes at ca. 1.5 inches bs. No strong evidence for subsurface remains of Feature 5 was located within these units.

\section{Bladed Areas (Area 1-Area 4)}

The bladed areas within the project area right-of-way encompassed a 735- $\mathrm{x}-55-\mathrm{ft}$ section closest to the fence line (minus a 50-x-45-ft gap around Feature 4), a ca. 775-x-10-20-ft section south of a non-bladed fire berm (measuring $10-15 \mathrm{ft}$ wide), and a bladed section measuring ca. $23 \times 130 \mathrm{ft}$ east of Feature 1 (Figure 5-9). Seventy anomalies (A1-A70) and isolated artifact finds were identified within the area horizontally bladed to ca. 3-5 inches bs by the $14 \mathrm{ft}$ maintainer. Several types of anomalies were delineated from the typical light brown sandy loam soil. These included isolated or multiple clusters of identifiable changes in soil color (i.e., orange soil, white soil), ash and charcoal deposits, small post hole-type depressions, pea size and larger gravel concentrations or alignments, limestone concentrations or alignments, and artifact concentrations. Anomalies A1-A70 are listed in Table 5-1. 


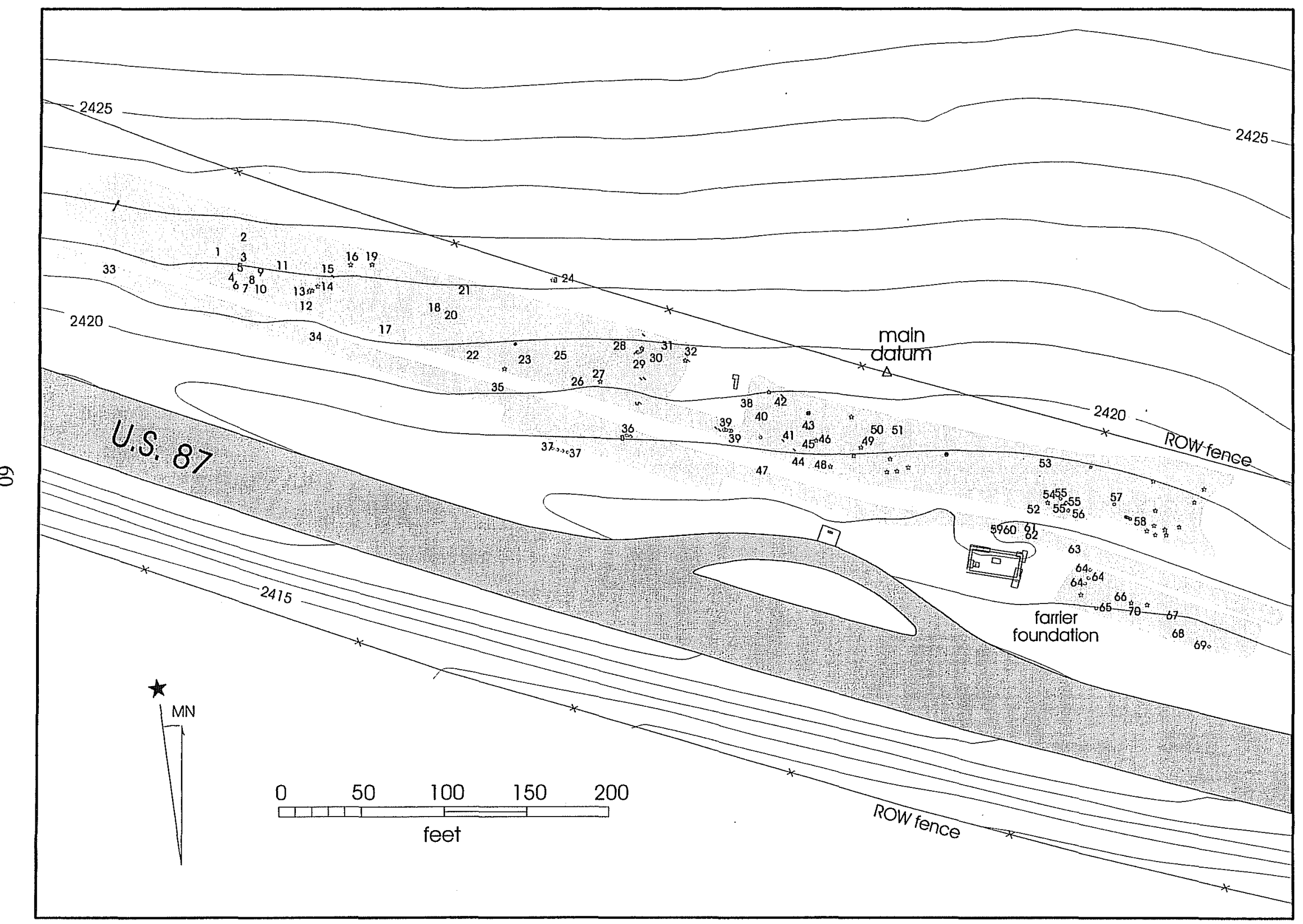

Figure 5-9. Bladed area excavations showing the locations of identified anomalies A1-A70. 
Table 5-1. Anomalies Identified in the Bladed Areas (ca. 3-5 inches bs)

\begin{tabular}{|c|c|}
\hline Anomaly \# & Anomaly Type \\
\hline $1-4$ & Orange soil \\
\hline $5-9$ & Possible post hole \\
\hline 10 & Possible post hole with gravel \\
\hline 11 & Gravel concentration \\
\hline 12 & Orange soil \\
\hline 13 & Orange soil and glass concentration \\
\hline 14 & Gravel concentration \\
\hline 15 & Orange soil \\
\hline 16 & Gravel concentration \\
\hline 17,18 & Orange soil \\
\hline 19 & Whitish soil (possible ash) \\
\hline 20 & Gravel concentration \\
\hline 21 & Whitish soil \\
\hline 22 & Orange soil \\
\hline 23 & Gravel concentration, burned rock and artifacts \\
\hline 24 & Artifact concentration (glass and chert) \\
\hline 25 & Whitish soil \\
\hline 26,27 & Gravel concentration \\
\hline 29 & Orange soil \\
\hline 30 & $\begin{array}{l}\text { Possible post hole and artifact concentration } \\
\text { (window glass, grommets with } 12 \mathrm{~d} \text { nails, and chert } \\
\text { fragments) }\end{array}$ \\
\hline 31 & Whitish soil \\
\hline 32 & Whitish soil and concentration of nail depressions \\
\hline 33 & Gravel concentration \\
\hline 34 & Concentration of gravel, charcoal and 1 piece of glass \\
\hline 35 & Ash deposit \\
\hline 36 & Limestone concentration and metal can fragment \\
\hline 37 & Limestone alignment \\
\hline 38 & Possible post hole \\
\hline 39 & $\begin{array}{l}\text { Limestone concentration, metal spike, square nails, and } \\
\text { orange soil }\end{array}$ \\
\hline 40 & Possible post hole \\
\hline 41 & Gravel concentration \\
\hline 42 & Gravel concentration with hor seshoe nails and metal star \\
\hline 43 & Gravel concentration with square nail \\
\hline $44-46$ & Gravel concentration \\
\hline 47 & Ash and or ange soil \\
\hline 48 & White soil \\
\hline 49 & Gravel concentration with charcoal \\
\hline 50 & Ash concentration \\
\hline 51 & White soil \\
\hline 52 & Gravel concentration with glass \\
\hline 53 & Ash concentration \\
\hline 54 & $\begin{array}{l}\text { Gravel concentration and } 2 \text { glass fragments } \\
\text { (1 with "... Boston ..." }\end{array}$ \\
\hline 55 & $\begin{array}{l}3 \text { limestone concentrations with horseshoe nail (possible } \\
\text { alignment) }\end{array}$ \\
\hline 56 & White soil \\
\hline
\end{tabular}


Table 5-1. continued

\begin{tabular}{cl} 
Anomaly \# & \multicolumn{1}{c}{ Anomaly Type } \\
\hline 57 & Ash and charcoal concentration with limestone rocks and \\
58 & metal fragments \\
$59-62$ & Artifact concentration (glass and ceramic sherds) \\
63 & Orange soil \\
64 & 3 Small limestone concentrations with glass (possible \\
65 & alignment) \\
66 & Warge limestone rock \\
67,68 & White soil and gravel concentrations \\
69 & Limestone and gravel concentration \\
70 & White soil \\
\hline
\end{tabular}

Several of the 70 anomalies identified within the bladed area were designated features. This was subjective because each anomaly could potentially be a feature. Feature identification was therefore distinguished by either a noticeable clustering of anomalies, large sized anomalies, or anomalies that potentially represented structural remains. Aside from the five features (Feature 1-5) identified during TxDOT's survey investigations, eight additional features were identified and designated Features 6-1, during CAR's investigations. For analytical purposes, the bladed area was divided into four areas (Area 1-4), and features identified within each area were described.

\section{Area 1}

Area 1 was a ca. 191-x-57-ft area, and included A1A17, A19, A33, and A34 (Figure 5-10). Eight of the anomalies were variously sized areas of orangecolored soil, ranging from ca. 0.5 - $\mathrm{ft}$ diameter to as large as ca. $3 \times 14 \mathrm{ft}$. Four anomalies included gravel concentrations ranging in size from ca. $2-9 \mathrm{ft}$ in diameter. One included a patch of white soil about 1 $\mathrm{ft}$ in diameter, and another consisted of a ca. 2-ft diameter concentration of charcoal, gravel, and ash. Isolated artifacts on the surface included a metal fork handle, found on the western edge of the bladed area, six pieces of bottle glass, and one cut nail. Two features (Feature 6 and 7) were identified within Area 1.
Feature 6

Feature 6 included anomalies A4-A10 and was comprised of an area of ca. 17 inches long by $4 \mathrm{ft}$ wide (Figure 5-10). The feature consisted of a 14-x-3-ft area of orange soil, with slightly grayer soil around the edges and six post hole-type depressions around it. The depressions measured from 3-6 inches in diameter. The distance between the depressions was ca. 2-4 ft. A6-A9 were roughly aligned.

\section{Feature 7}

A11 was designated Feature 7 because it was a considerably large gravel concentration. It measured ca. $9 \times 9 \mathrm{ft}$ and consisted of dense pea size gravels intermixed with 1-3-inch diameter cobbles.

\section{Area 2}

Bladed Area 2 included an area approximately $170 \mathrm{x}$ $50-55 \mathrm{ft}$, and a thinner section (ca. $13-23 \mathrm{ft}$ wide) south of the firm berm gap (Figure 5-11). A18, A20 A25, A26-A32, and A35-A37 were identified in Area 2. A24 was a surface cluster of green bottle glass fragments and a tin can located outside the bladed area, adjacent to the right-of-way fence line. The types of anomalies represented in Area 2 include orange soil areas (A18, A22, and A29), white soil areas (A21, $\mathrm{A} 25, \mathrm{~A} 31$, and $\mathrm{A} 32$ ), gravel concentrations (A20, A23, A26, and A27), one gravel concentration within whitish soil (A28), a post hole-type depression with an artifact scatter (A30), an ash deposit (A35), a small limestone cluster (A36), and a limestone alignment 


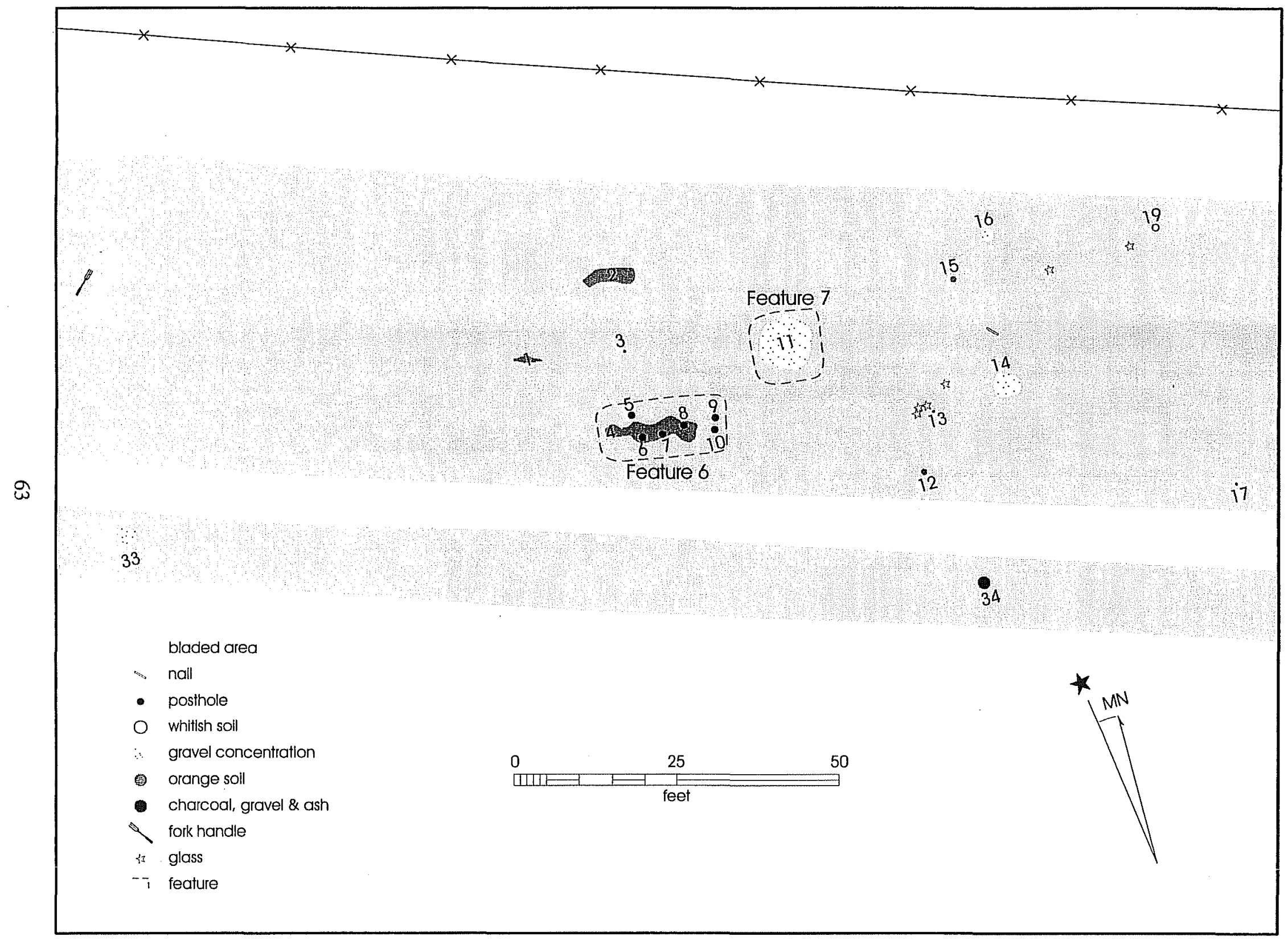

Figure 5-10. Anomalies and Features 6 and 7 identified within Bladed Area 1. 
(A37). Isolated artifacts in Area 2 included glass, nails, charcoal fragments, a complete horseshoe, and undiagnostic lithic debitage fragments. One feature (Feature 9) was identified within Area 2. TxDOT's Feature 5 was located within Area 2 in the same location where the complete horseshoe and one cut nail were recovered. Thus, Feature 5 was comprised of a small artifact cluster. Based on these subsurface results, and the criteria used for distinguishing the individual features, Feature 5 did not qualify as a feature.

\section{Feature 8}

Anomaly A37 was designated Feature 8 (Figure 5-11). This feature was not located within the bladed area but discovered on the ground surface while mapping the Area 2 bladed area. Feature 8 consisted of a ca. 20-22-ft long limestone rock alignment. Several large stones were visible on the surface. No artifacts were found on the surface in association with the feature.

\section{Feature 9}

Feature 9, in the northeastern part of Area 2, was comprised of anomalies A28-A30 and a scattering of artifacts. The feature encompassed an area of ca. $40 \mathrm{x}$ $20 \mathrm{ft}$. A28 included a whitish soil area, ca. 9 x $4 \mathrm{ft}$, mixed with fine gravels. A29 was an area of orange and gray soil that was oval in shape and measured ca. $1 \times 2.5 \mathrm{ft}$ (Figure 5-12). A30 included a possible post hole-type depression, ca. 4-6 inches, with a concentration of artifacts. The artifacts included two grommets with $12 \mathrm{~d}$ size cut nails attached (Figure 5-13), flat or window glass, and chert fragments.

\section{Area 3}

Bladed Area 3 encompassed a 10-12-x-50-ft section south of the unbladed Feature 4 gap, a ca. $45-\mathrm{x}-120-\mathrm{ft}$ area to the east, and an area south of the fire berm gap measuring ca. $12-28 \times 165 \mathrm{ft}$. A38-A51 were identified and recorded within Area 3 (Figure 5-14). The anomaly types in Area 3 included post hole-type depressions (A38 and A40), a limestone concentration with artifacts (A39), two gravel alignments (A41A42), five gravel concentrations (A43-A46 and A49), one orange soil and ash concentration (A47), one ash deposit (A50), and two white soil concentrations (A48 and A50). Within bladed Area 3, two previously located features identified by TxDOT (Features 2 and 3 ) and one newly designated feature (Feature 10) were examined.

\section{Feature 2}

A51 fell within the boundary of TxDOT's Feature 2, and included a ca. 5-ft area of whitish colored soil (Figure 5-14). Based on the bladed area results, A51 as a single anomaly would not meet the criteria of a designated feature. However, this may not be the case when combined with the same area test excavation artifact results.

\section{Feature 3}

Within bladed Area 3, Feature 3, originally measured at ca. $15-17 \mathrm{ft}$ in diameter by TxDOT (Figures 2-4 and 5-2), was extended to include an area measuring ca. $30 \mathrm{ft}$ maximum width (orientated east-west) by ca. $50 \mathrm{ft}$ maximum length (oriented north-south). The feature encompassed anomalies A41-A46 and A48, and was by far the most substantial feature identified within the bladed areas. A41 and A42 were linear, pea-size gravel concentrations that appeared to be aligned with each other in a north-south direction (Figure 5-14).

A41 measured ca. $15 \mathrm{ft}$ long (north-south) by $1.5-2 \mathrm{ft}$ wide, and had an offshoot measuring ca. $3 \times 1.5 \mathrm{ft}$ coming off at a right angle about $2.5 \mathrm{ft}$ from its south end. Square nails were found in and around the gravel alignment, and a 4-hole metal button was recovered from the north end of A41. A41 and A42 were separated by a ca. $10 \mathrm{ft}$ gap. A42 was another gravel alignment that appeared to have continued north but was under the back dirt pile created by the maintainer. The portion that remained measured ca. $10 \times 1-2.5 \mathrm{ft}$, with the northern section widening to $\mathrm{ca} .4 \mathrm{ft}$. Cut nails were found in the gravel of A42. A43 included a smaller (ca. 2.5-ft in diameter), more circular, peasize gravel concentration with a cut nail. The distance between the center of the northern edge of A41 to the center of A43 was ca. $12.5 \mathrm{ft}$. A miscellaneous metal fragment was ca. $7 \mathrm{ft}$ north of A43. A44 was south of A41 at a distance of ca. $7 \mathrm{ft}$ and included another small (ca. $2 \times 3 \mathrm{ft}$ ), oval, pea-size gravel concentration with another $0.5-\mathrm{x}-1.5-\mathrm{ft}$ concentration ca. $4 \mathrm{ft}$ west of it. 


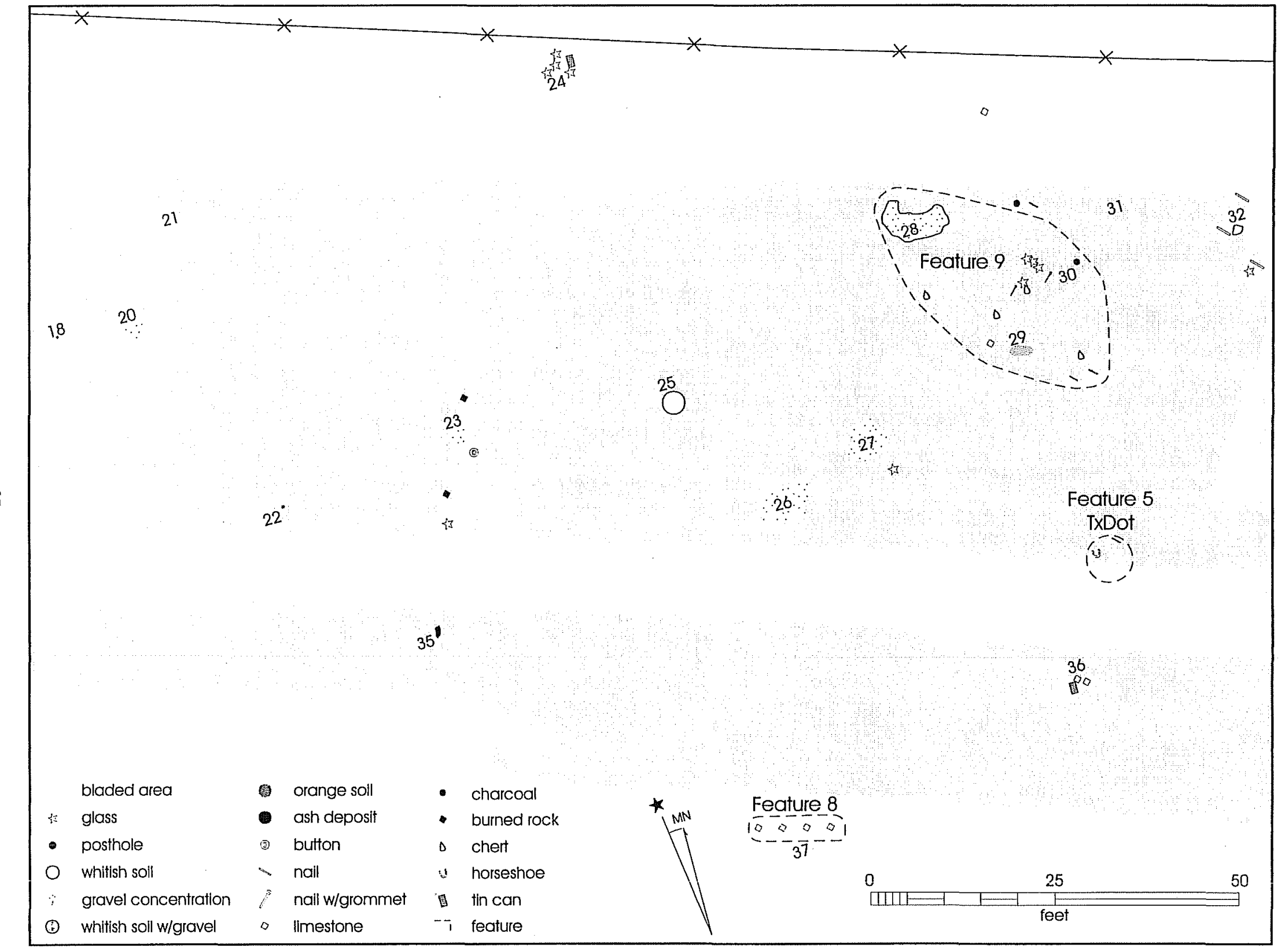

Figure 5-11. Anomalies and Features 5 and 9 identified within Bladed Area 2. 


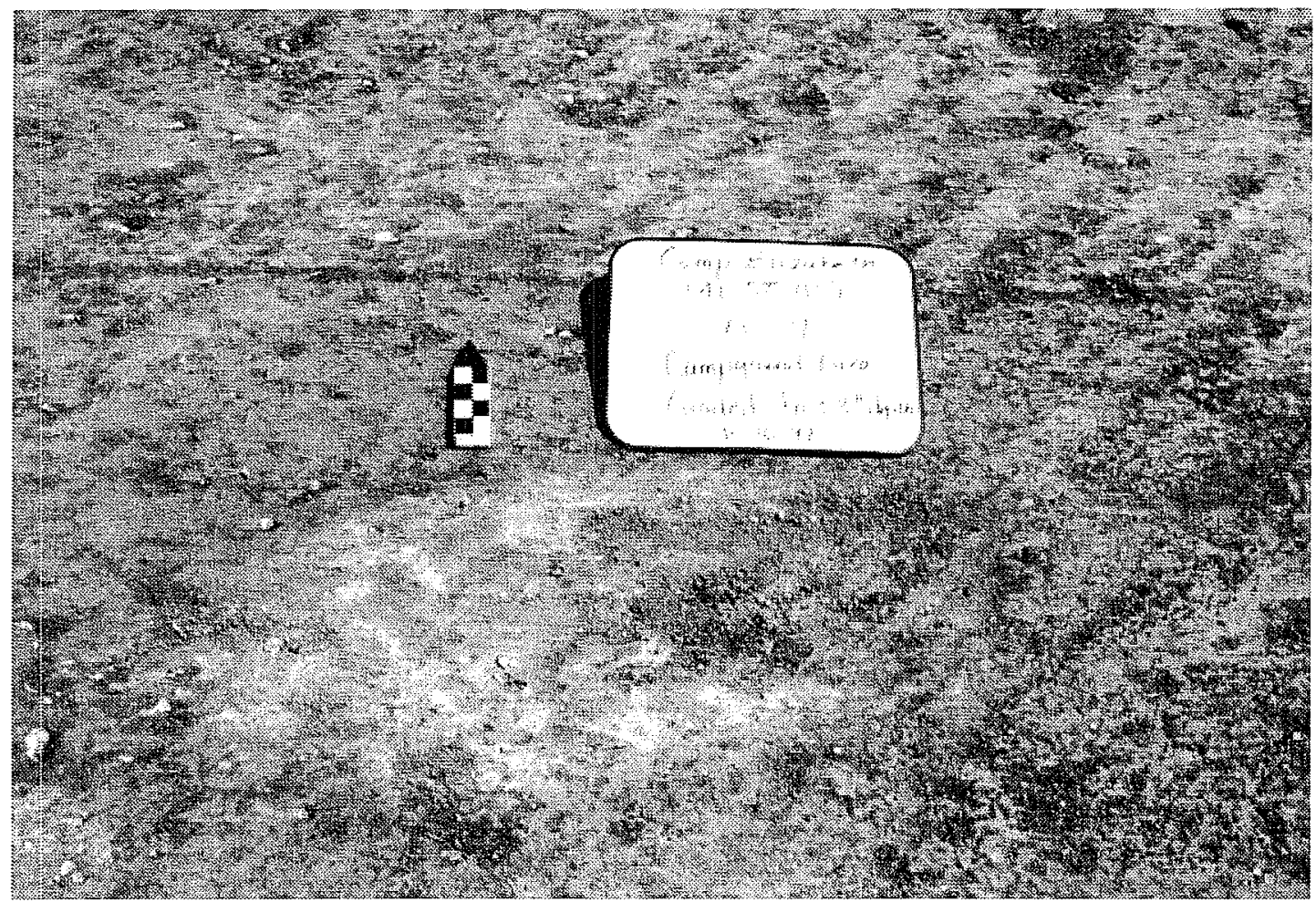

Figure 5-12. A29: Orange soil concentration.

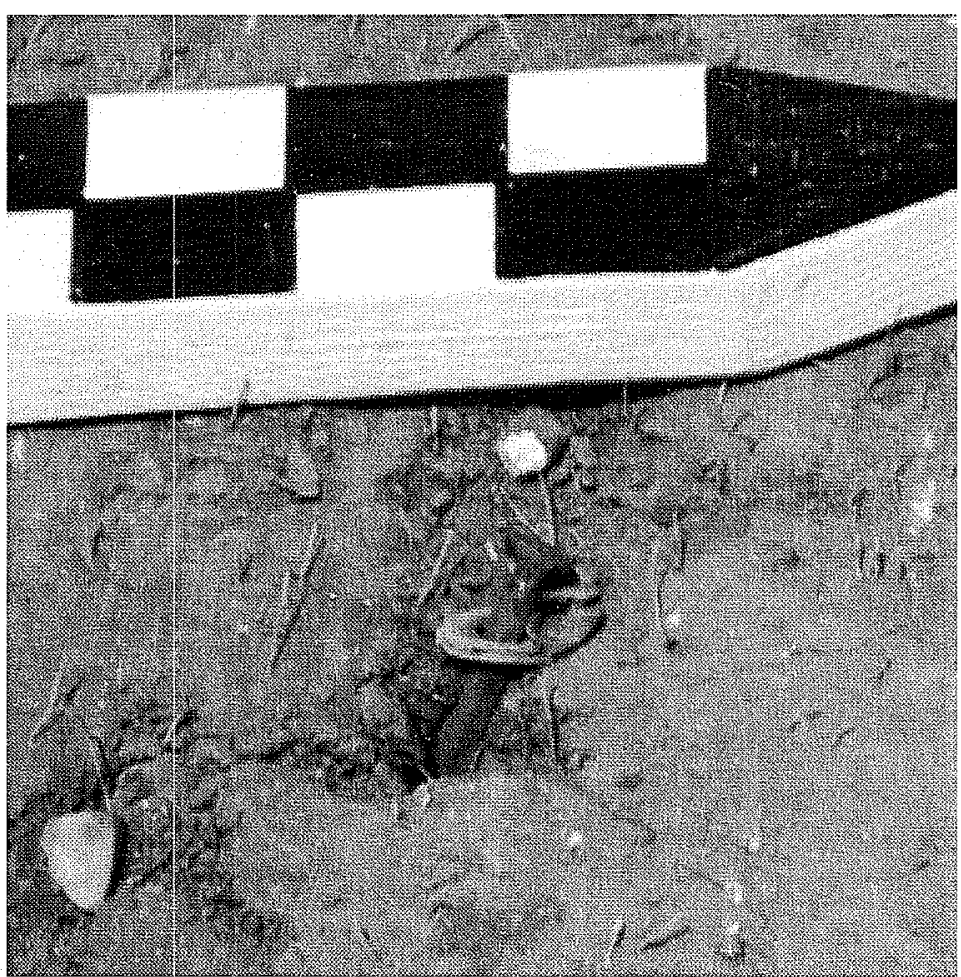

Figure 5-13. A30: 12d cut nail with grommet and window glass.
A45 was an even smaller (ca. $1.5 \times 2 \mathrm{ft}$ ) gravel concentration ca. $7 \mathrm{ft}$ east of the southern edge of A41. The A46 gravel concentration was ca. $2.5 \mathrm{ft}$ east of A45, ca. $12.5 \mathrm{ft}$ from the center of the southern edge of A41 to the center of A46, and ca. $12.5 \mathrm{ft}$ due south of A43. A48 comprised a ca. 6 -ft diameter area of white soil. If all the gravel concentrations and alignments were associated with one large feature, then the total length would be approximately $30 \mathrm{ft}$ (north-south) and the width ca. $12.5 \mathrm{ft}$ (eastwest). However, there may be multiple features within Feature 3. For example, A42 may have been a separate structural feature; and A41, A43, A45, and A46 another. If this is the case, the latter feature's dimensions would be ca. $12.5 \mathrm{ft}$ square.

\section{Feature 10}

Anomaly 39 was designated Feature 10 because it was a concentration of limestone (some showing evidence of having been heat treated), a metal spike, cut nails, and cut nail depressions. The limestone concentration was 


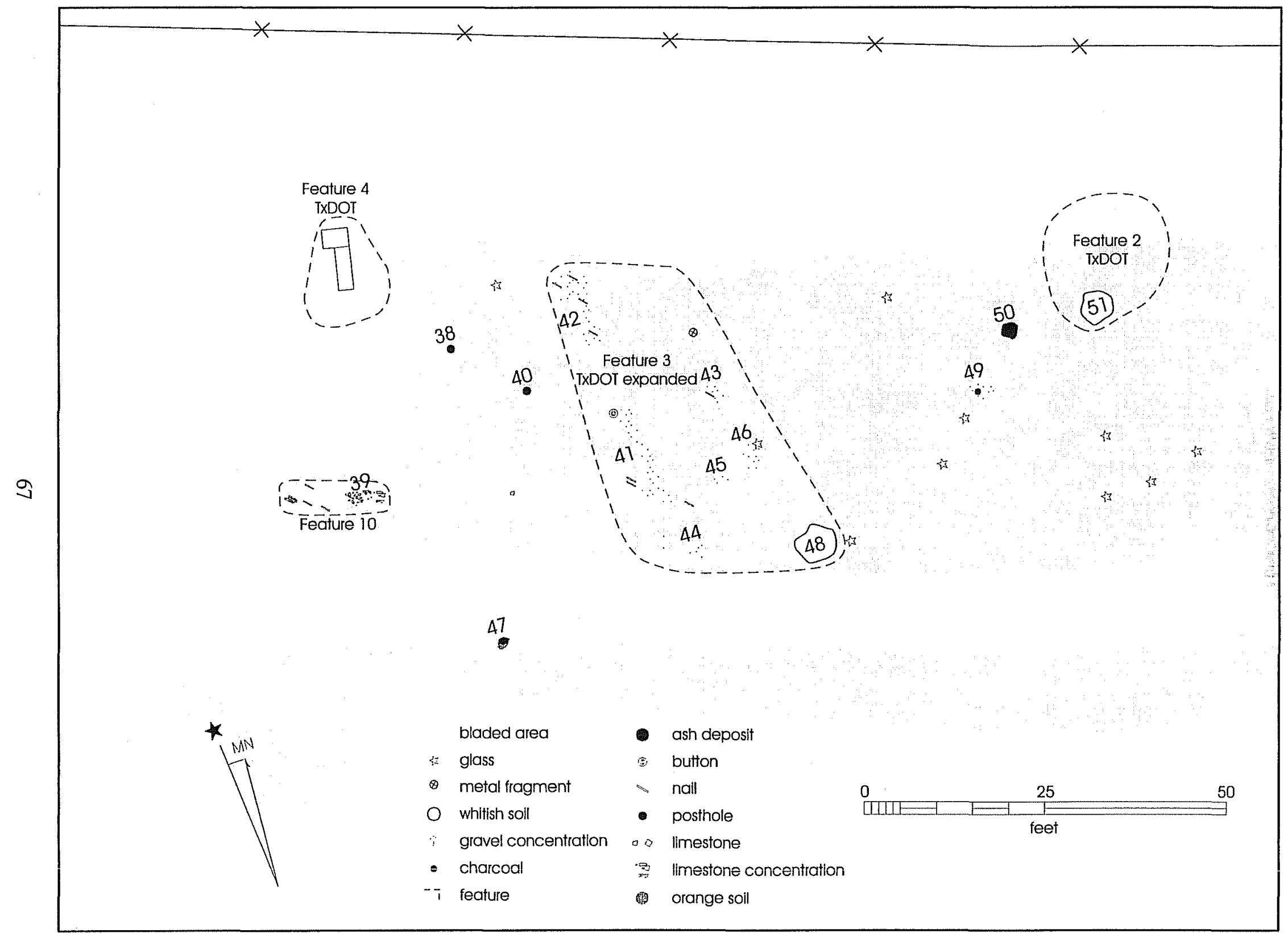

Figure 5-14. Anomalies and Features 2, 3, 4, and 10 identified within Bladed Area 3. 
oriented in an east-west direction and measured ca. 2 $\mathrm{ft} \times 5 \mathrm{ft}$. The largest stones (ca. 0.5 to $1 \mathrm{ft}$ size) were located in the northwestern area of the feature.

\section{Area 4}

Bladed Area 4 included a large section (ca. 45-50 x $190 \mathrm{ft}$ ) just south of the right-of-way fence line, a small (ca. $12 \times 210 \mathrm{ft}$ ) strip just south of the fire berm gap of unbladed area, and another (ca. $23 \times 130 \mathrm{ft}$ ) section ca. $25 \mathrm{ft}$ east of Feature 1. Anomalies A52-A70 were located in Area 4 (Figure 5-15). The anomaly types identified within Area 4 included several gravel concentrations (A52, A54, A59-A62, A66), one orange soil patch (A63), two ash deposits (A53 and A57), three limestone concentrations or alignments (A55, A64-A65), a limestone and gravel concentration (A69), four areas of white soil (A56, A67-A68, and A70), and one artifact concentration consisting of undiagnostic glass and ceramic fragments. Several isolated artifacts were found on the bladed 3-5 inch level surface. These include a metal fragment, bottle glass fragments, and a pitted hand-made glass marble. Three features were identified from Area 4 and designated Features 11, 12 and 13 (Figure 5-15).

\section{Feature 11}

Feature 11 encompassed A55 and A56. A55 consisted of three small clusters (ca. 1.5-2 ft diameter) of limestone rock forming a ca. 10-ft-long alignment oriented in a northwesterly direction. The clusters were spaced from approximately 2-3 ft apart. A horseshoe nail was located within the middle cluster of limestone rocks. A56 included a small, ca. 4-6 inch-diameter, white soil area.

\section{Feature 12}

Anomaly 57 was designated Feature 12 because it was comprised of a well-defined ash, charcoal, and small chunks of limestone rock concentration, intermixed with cultural material (Figure 5-16). These artifacts included miscellaneous metal fragments and a metal button. Feature 12 was oval in shape and measured ca. $1.5 \times 1.75$ inches
Feature 13

Anomalies 64-65 were designated Feature 13. These included a semi-linear alignment of limestone rocks that were roughly oriented in a north-south direction ca. 35-40 east of the eastern wall of Feature 1. A64 was comprised of three clusters of limestone rocks that measured ca. $10 \mathrm{ft}$ long by $0.5-1 \mathrm{ft}$ wide. The clusters were spaced ca. 3-4 ft apart. A65 included two isolated limestone rocks located ca. $10 \mathrm{ft}$ to the southeast of A64's southernmost rock cluster.

\section{Artifact Descriptions}

\section{José E. Zapata and Maureen Brown}

Over the course of the archaeological investigations, 792 artifacts were recovered from 41ST111 (Table 5-2 and Appendix B). U1-U89 yielded 749 artifacts, 41 artifacts were recovered from the bladed area, and two artifacts were collected from the surface. As described below, the artifacts recovered from the investigations at Camp Elizabeth confirm the presence of a U.S. military encampment. Additionally, there is a prehistoric component. For analysis and discussion, the artifacts have been grouped into eight categories. These are presented in their increasing order of relevance to the suggestion that the site was utilized as a military encampment: Lithics, Faunal, Miscellaneous, Activities, Domestic, Construction, Workshop, and Personal.

\section{Lithics}

This category is comprised of undiagnostic lithic debris. Thirty-nine lithic fragments were recovered: 33 flakes weighing 86.9 grams $(2.8 \mathrm{oz})$ and 6 chert nodules weighing 108.6 grams $(3.5 \mathrm{oz})$.

\section{Faunal}

Thirty-four vertebrate faunal remains, weighing $113.74 \mathrm{~g}$, were recovered during the project. Most of the faunal remains were highly fragmented. Table 5-3 shows the results of the analysis of these bones. Only two species could be identified-black-tailed jack 


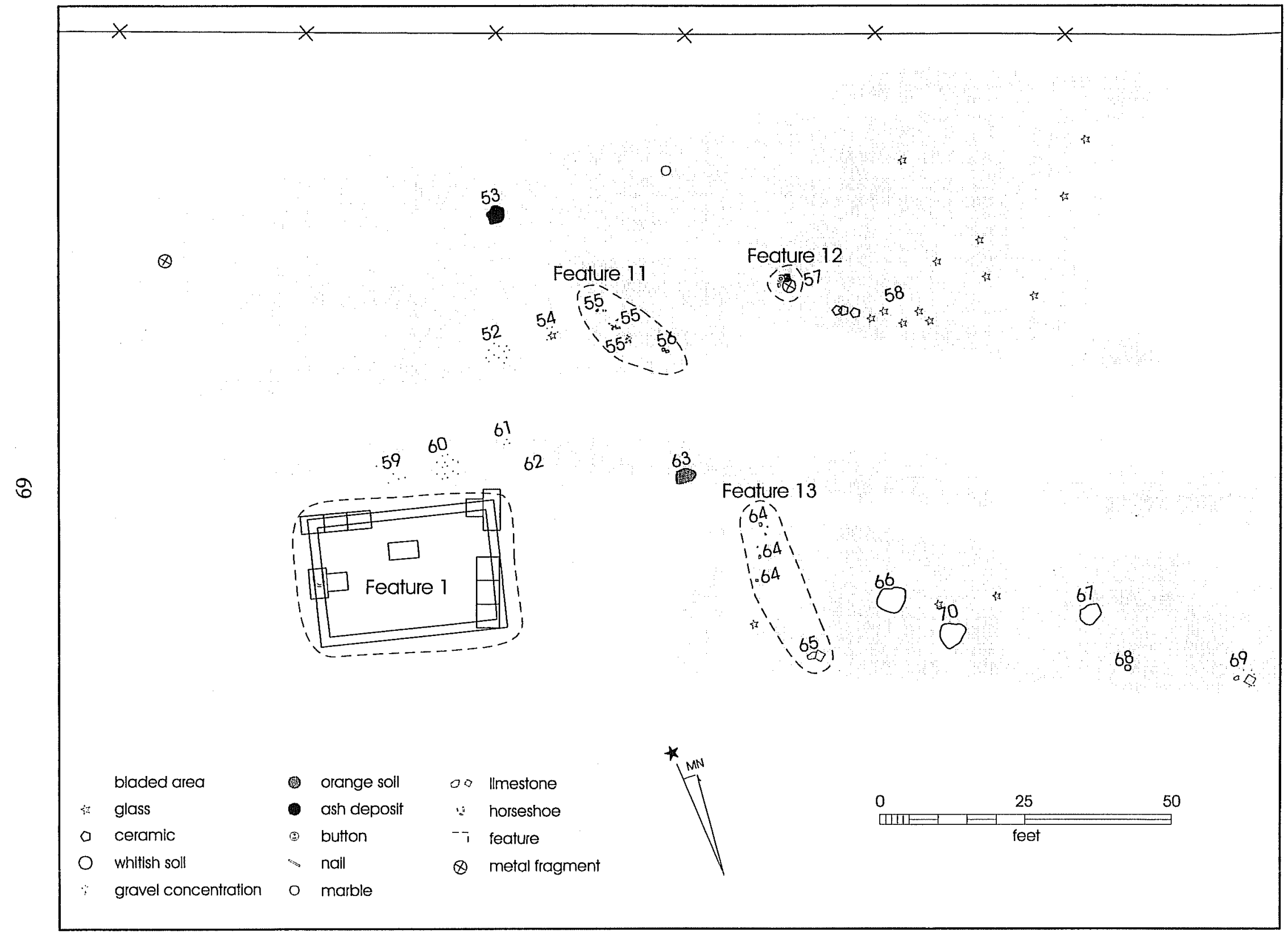

Figure 5-15. Anomalies and Features 1, 11, 12, and 13 within Bladed Area 4. 
Table 5-2. Total Artifacts from Project Area Per Artifact Category

\begin{tabular}{lcccc}
$\begin{array}{l}\text { Artifact } \\
\text { Category }\end{array}$ & $\begin{array}{c}\text { Units } \\
\text { (U1-U89) }\end{array}$ & $\begin{array}{c}\text { Bladed } \\
\text { Area }\end{array}$ & Surface & Total \\
\hline Activities & 4 & 1 & 0 & 5 \\
Construction & 119 & 12 & 0 & 131 \\
Domestic & 232 & 10 & 0 & 242 \\
Faunal & 34 & 0 & 0 & 34 \\
Lithics & 35 & 4 & 0 & 39 \\
Miscellaneous & 145 & 7 & 0 & 152 \\
Personal & 4 & 4 & 0 & 8 \\
Workshop & 176 & 3 & 2 & 181 \\
\hline \multicolumn{1}{c}{ Totals } & $\mathbf{7 4 9}$ & $\mathbf{4 1}$ & $\mathbf{2}$ & $\mathbf{7 9 2}$
\end{tabular}

rabbit and turkey. Both were probably hunted in the immediate area. A fragment of unidentified turtle bone was from a large specimen that may have been eaten. The remainder of the bone is probably from cattle slaughtered for food. Only two bones showed butcher marks. One was a hand saw-cut fragment of an innominate. The other, also from an innominate, had a chop mark made with a sharp metal blade. Most of the bone showed extensive surficial pitting, the result of chemical weathering. None of the bone showed evidence of atmospheric weathering, suggesting that it was all buried quickly.

\section{Miscellaneous}

This category covers a broad range of unidentifiable and undiagnostic material including a clod of burnt soil, metal fragments, mussel shell fragments, and charcoal fragments. In all, 152 specimens, weighing $317.5 \mathrm{~g}$ $(10.2 \mathrm{oz})$, were recovered. Unidentifiable metal fragments (141, weighing $276 \mathrm{~g}$ [8.9 oz]) comprised the highest volume of material ( 93 percent of the total) for this category. In addition, 25.3 grams $(.8 \mathrm{oz})$ of charcoal fragments were recovered.

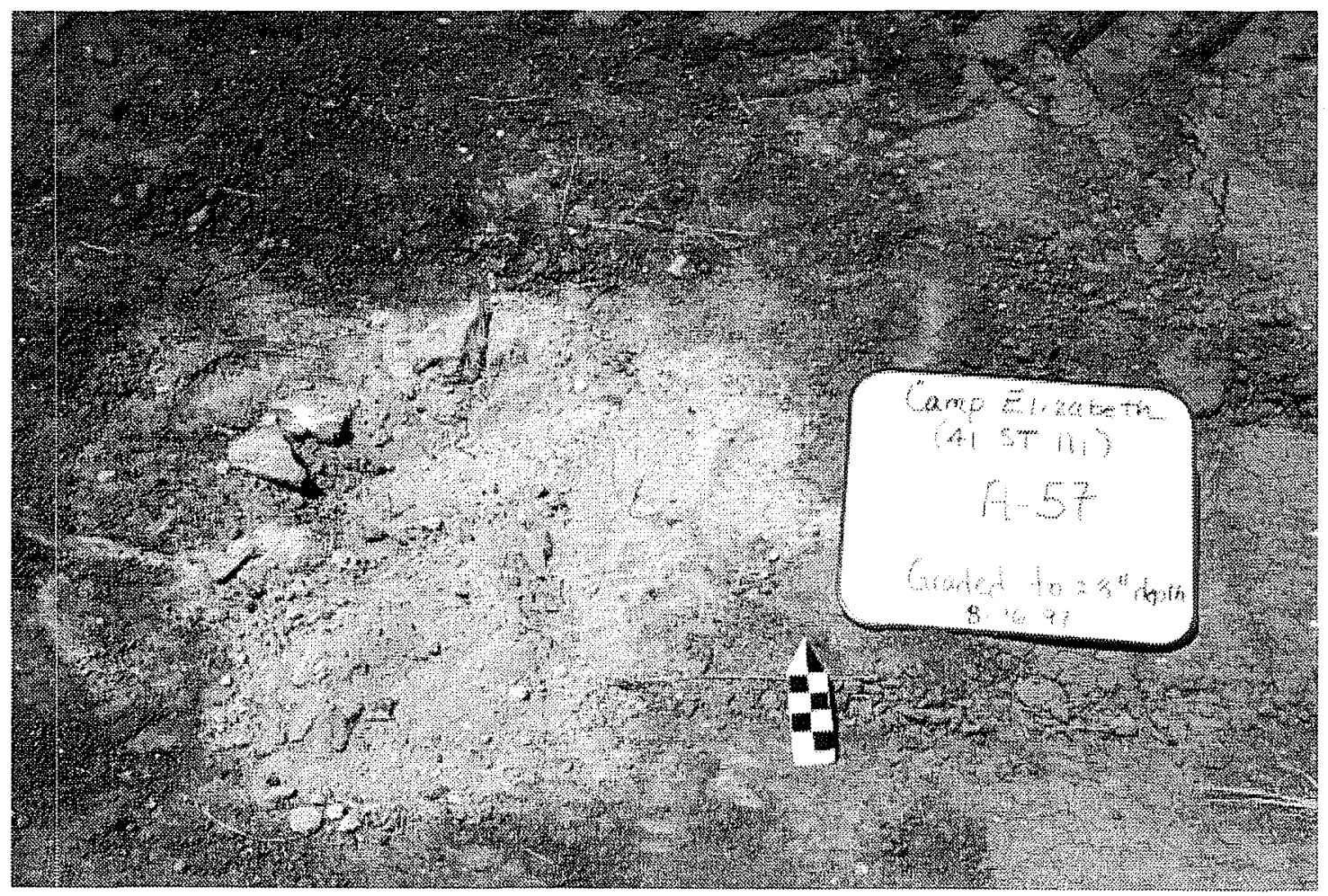

Figure 5-16. Feature 12 (A57): ash, charcoal, limestone, and artifact concentration . 
Table 5-3. Identified Taxa

\begin{tabular}{|r|r|l|r|r|l|l|}
\hline Unit & Le vel & \multicolumn{1}{|c|}{ Taxon } & Count & Weight & Element & Notes \\
\hline 4 & 1 & Bovinae & 1 & 2.49 & Fra gment of innominate & Hand saw cut \\
\hline 60 & 1 & Mammal & 1 & 0.14 & & \\
\hline 73 & 1 & Bovinae & 1 & 38.45 & Fra gment of ilium & 1 chop mark, pitted surface \\
\hline 73 & 1 & Mammal & 16 & 4.33 & & \\
\hline 78 & 1 & Meliagris gallopavo & 2 & 8.24 & Distal $1 / 2$ of tibiotarsu s & 2 frags which mend, pitted \\
\hline 79 & 1 & Mammal & 1 & 0.46 & & Pitted \\
\hline 84 & 1 & Lepus californicus & 1 & 0.41 & Distal $1 / 2$ of radius & \\
\hline 84 & 1 & Mammal large mammal & 6 & 52.16 & & Pitted \\
\hline 84 & 1 & Testudinata & 4 & 5.08 & & Pitted \\
\hline
\end{tabular}

\section{Activities}

The five artifacts found within this category were associated with activities related to shooting (firearms), playing, writing, and possibly polishing. Two firearm remains were found. One is a possible .50 caliber shell casing fragment (Figure 5-17a); the other is an unfired, but fragmented, .50 caliber cartridge (Figure 5-17b) of the center-fire type. Its total length is 2.75 inches, and it has a conical round nose

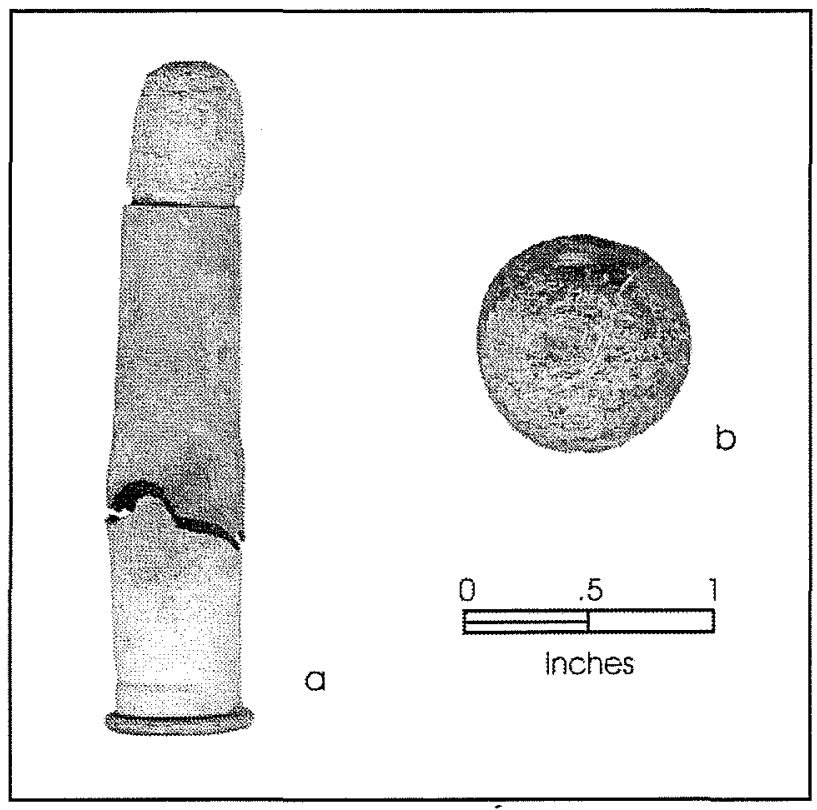

Figure 5-17. Activity-related artifacts. a) .50 shell casing and cartridge; b) glass swirl marble. bullet. The cartridge is crimped $3 / 16$ inches from the base and lacks markings. This specimen is most similar to a historical cartridge classified as a $45 / 70$ Benet, manufactured for the Springfield Model 1866 rifle (Logan 1959). This crimped cartridge variety with powder was a Cavalry cartridge (Joe Manguso, personal communication 1998). Investigations also recovered a slate fragment, possibly from a writing tablet, and a toy glass marble (Figure 5-17c). The marble is heavily pitted and fractured, but has been identified as a German hand-made, multi-colored swirl dating to ca. 1845-1910 (Carskadden and Gartley 1990). Additionally, the bottom of a flat tin can container possibly used to hold boot or saddle polish was recovered from this site. It measures $3 / 4$ inches $(19 \mathrm{~mm})$ in height and $23 / 4$ inches $(69 \mathrm{~mm})$ in diameter Just below the rim is a groove so that a lid could be attached.

\section{Domestic}

This category was used for cultural material relating to consumer or household goods. Within this category is a large collection of bottle glass, as well as a complete bottle, a fork handle, an iron lid fragment, a tin can, a tin can base and top, drinking glass vessel fragments, and one undecorated whiteware fragment, totalling 243 items. 
Bottle glass made up the highest volume of material in this category, consisting of 219 fragments weighing $821.2 \mathrm{~g}(26.4 \mathrm{oz})$. Of these, 174 fragments weighing

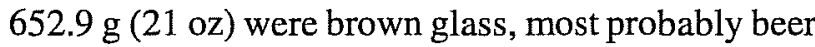
bottle glass. These included five diagnostic bottle neck fragments and five base fragments. A complete brown beer bottle, measuring 11\%/4 inches $(295 \mathrm{~mm})$ in height was recovered (Figure 5-18a). The complete bottle and one bottle base fragment were impressed with an "TG Co" maker's mark. Toulouse (1971) lists the manufacturer as the Ihmsen Glass Company of Pittsburgh and dates the beer bottle to ca. 1870-1895. Only one other glass fragment has an identifying mark. This specimen was of clear glass with an impressed label ". . . Boston ...." The maker is unknown, but it probably represents a medicine bottle fragment. Dark green glass, probably wine bottle glass, was represented by 10 undiagnostic fragments. Other probable medicine bottle glass was represented by 23 aqua bottle glass fragments. In addition to bottle glass, three clear glass sherds from a drinking vessel with a folded glass rim were recovered.

The only other artifact from the domestic category which may be diagnostic is a decorated iron fork handle (Figure 5-18b). It is impressed with a floral pattern on both sides. This artifact may be associated with a standard issue military mess kit as suggested by Cheek (1977).

\section{Construction}

This category is comprised of an assortment of construction-related material including cut nails, an insulator (small fragment), four fencing staples, a cut spike (Figure 5-19a), a possible hinge, possible tent stakes, and window glass. The insulator is undiagnostic, and the fencing staples are probably associated with an earlier, and recently relocated, property line fence. The nine window glass fragments are undiagnostic, and the possible hinge, though fairly large and heavy, is as yet unidentified. A square nut and bolt fragment and a flat metal washer were also recovered.

One rather large machine-cut nail (30d) was recovered and is believed to be a tent stake (Figure 5-19b). Two

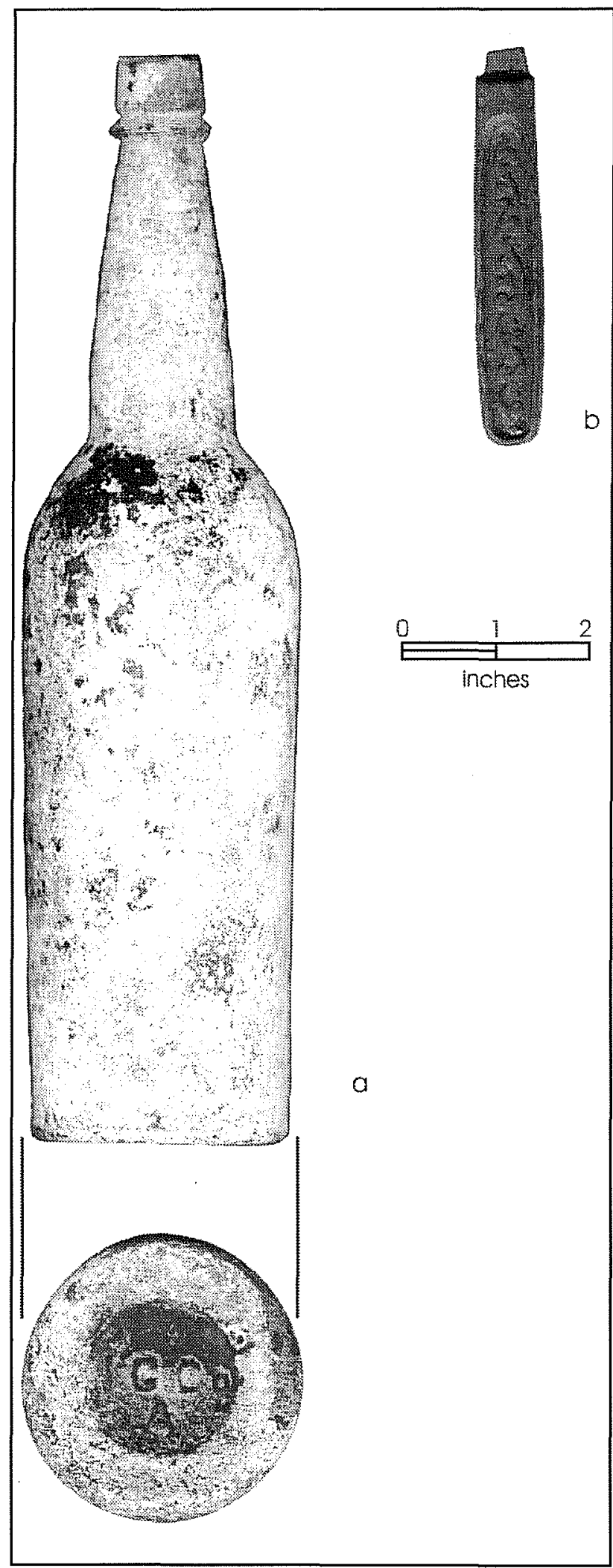

Figure 5-18. Domestic artifacts. a) Complete brown beer bottle with "IG Co" makers mark on base of bottle; b) metal fork handle. 


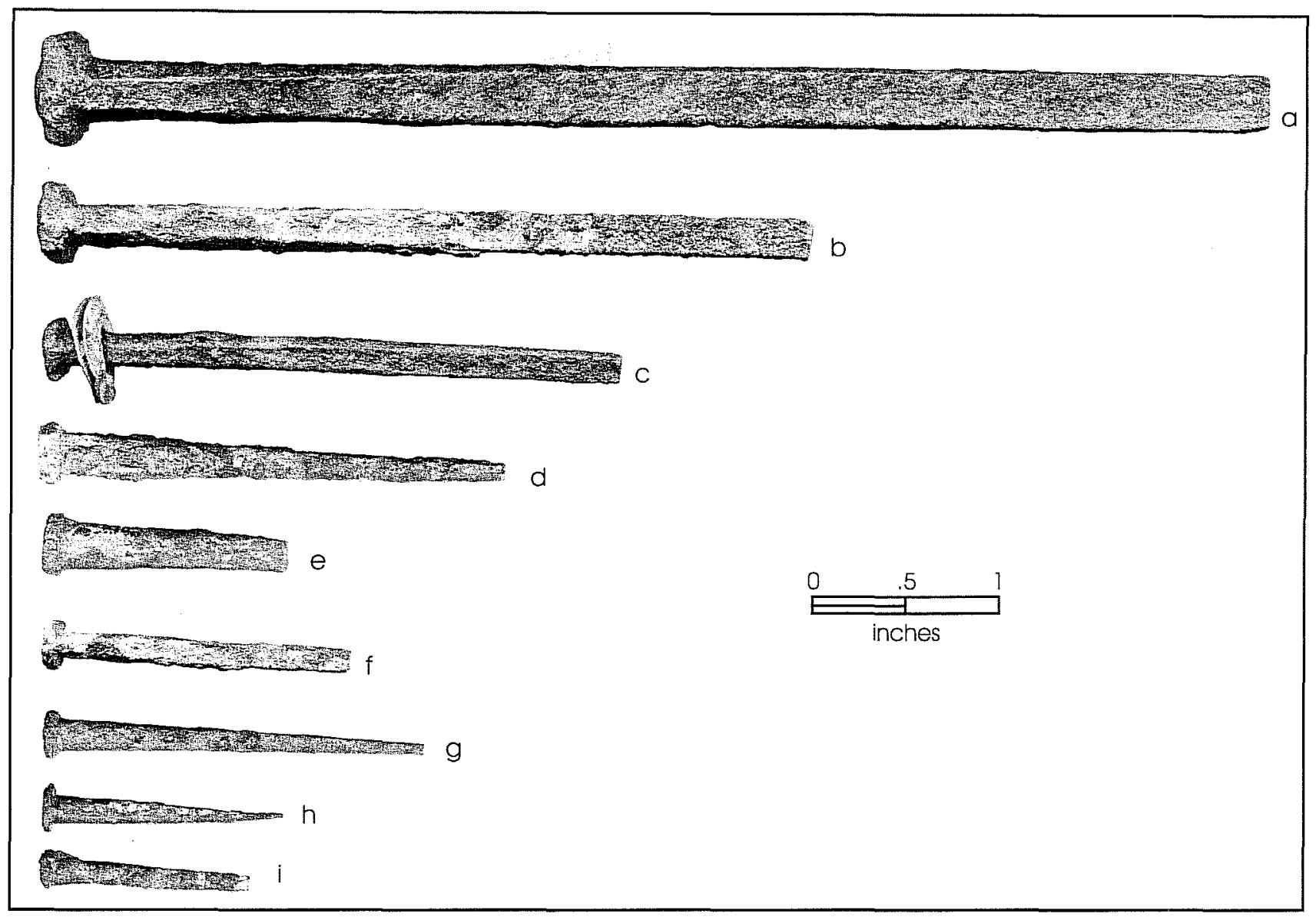

Figure 5-19. Construction artifacts. a) cut spike; b) 30d nail; c) 12d nail and grommet; d) 10d nail; e) 9d nail; f) $8 \mathrm{~d}$ nail; g) $7 \mathrm{~d}$ nail; h) $6 \mathrm{~d}$ nail; and i) $5 \mathrm{~d}$ nail.

machine-cut nails (12d) with grommets were also located (Figure 5-19c). These are definitely associated with tent construction. From the small size of the nails ( $3 \frac{1}{16}$ inches long), it is unlikely that they would have been driven into the ground to secure a tent. They may have been either attached to the end of a tent pole (Quartermaster General 1986:21), or have secured a canvas tarp roof on top of a picket-type tent (John Clark, personal communication 1998; Wooster 1987:29).

A total of 110 machine-cut nails, weighing $261.5 \mathrm{~g}$ (8.4 oz), was recovered. Of these, 79 were diagnostic (including the two nails possibly used to stake-down canvas tarps for tents). These were easily identified as $5 \mathrm{~d}(2), 6 \mathrm{~d}(6), 7 \mathrm{~d}(27), 8 \mathrm{~d}(21), 9 \mathrm{~d}(2), 10 \mathrm{~d}(5)$, and 12d (16) (Figures 5-19c-i). According to Sam Kilsby (personal communication 1997), the $5 \mathrm{~d}$ and $7 \mathrm{~d}$ nails are typically used for flooring; the $6 \mathrm{~d}$ nails for nailers (shingle or shake roof systems); the $8 \mathrm{~d}$ and $9 \mathrm{~d}$ nails for flooring, siding, and/or roofing; the $10 \mathrm{~d}$ nails for roof decking; and the $12 \mathrm{~d}$ nails for framing and ceiling joists. Common, machine-cut nails date to ca. 1838 1890 (Nelson 1968).

\section{Workshop}

Items in this category are associated with barn and/or workshop activities (i.e., workshop tools, products, and by-products). One hundred eighty-three items were classified within this category. From the total, 172 were associated with activities related to a farrier's shop. These included three complete and one fragmented horseshoe (Figures 5-20a, b). In addition, 77 (193.5 g [6.2 oz]) horseshoe nails with three different shapes of nail heads (Figures 5-20c-e), 15 (376.2 $\mathrm{g}$ [12.1 oz]) pieces of iron cuttings off the ends of horse/mule shoes (Figure 5-20f), and 76 (222.4 g [7.2 oz]) slag nodules were recovered. The remaining 


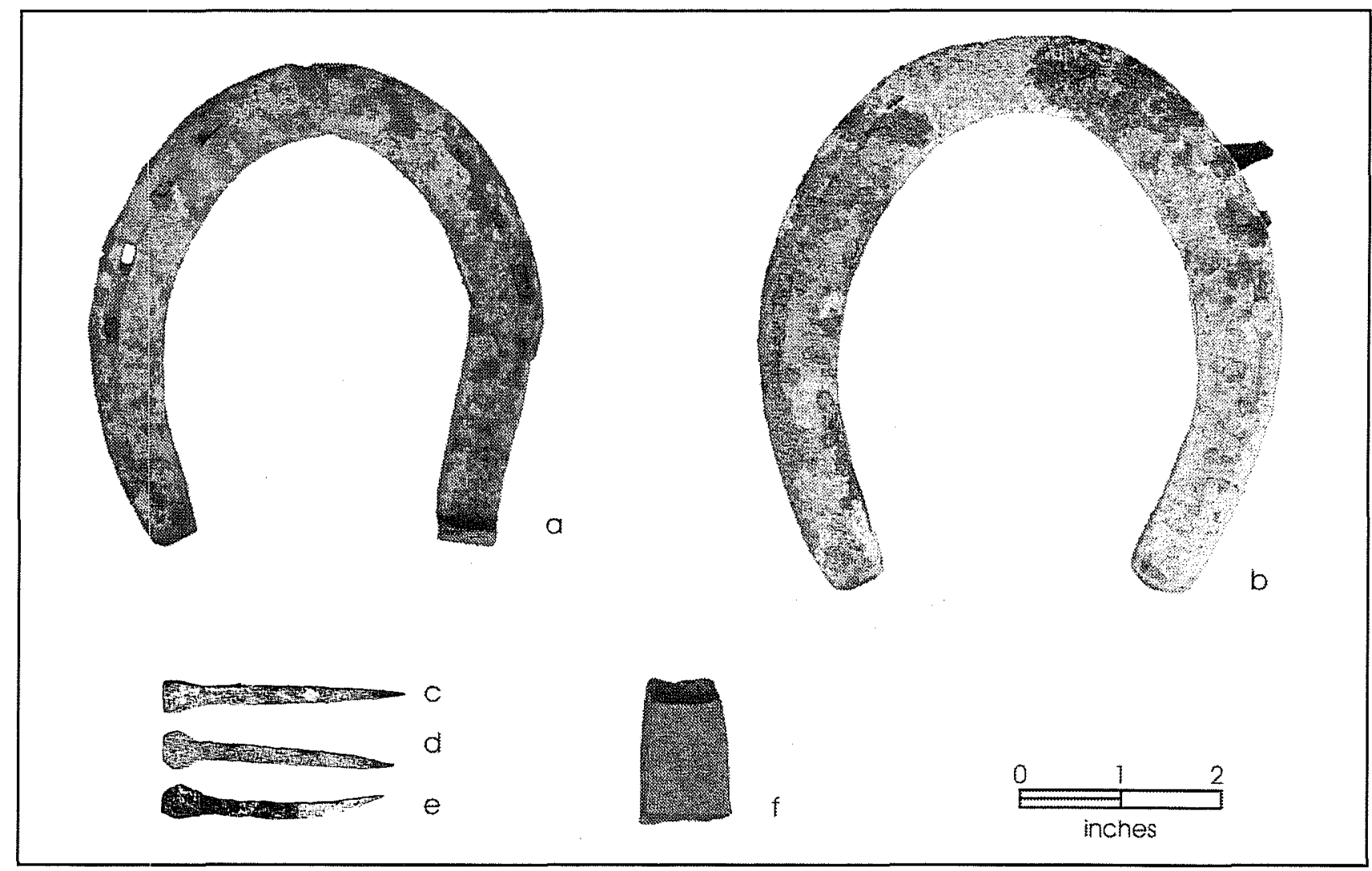

Figure 5-20. Workshop artifacts. a, b) complete horseshoes; c, e) horseshoe nails; f) iron cutting from a horseshoe.

nine items include a chain link fragment, wire fragments, metal strapping, and other metal fragments.

\section{Personal}

Objects assigned to this category typically relate to clothing, personal care, and jewelry. At this site, only items related to clothing and clothing decorations were recovered. Six buttons, one ornamental star stud, and one partial military insignia were recovered.

Three of the six buttons are definitely militaryGeneral Service uniform coat buttons (Quartermaster General 1986:84). These are three-piece, convex metal buttons with a stamped plain eagle facing left on the front. The front was sometimes made of gilded metal for officers or brass for enlisted men, while the back is brass with a copper eye or loop soldered to the back for attaching to the uniform (Brinckerhoff 1976:2). The uniform buttons came in two sizes: a smaller one for the vests and a larger size for the coat (Quartermaster General 1986:84-85). The recovered buttons, at $20 \mathrm{~mm}$ in diameter, were the coat size. Two of the military buttons are marked "SCOVILL MFG CO WATERBURY" (Figures 5-21a, b). This company, still in operation, was founded in 1850 (Cheek 1977:55). One is still in excellent condition while the other has a flattened surface. The other military button was marked "WATERBURY BUTTON CO" (Figures 5-21c). This company manufactured buttons from ca. 1849 to $1919+$ (Cheek 1977:55). This button also has a flattened surface and is in fair condition. All three buttons are of the type of plain eagle front decorated buttons that date to ca. 1855-1884, and are distinguished by the recessed, wide, flat, and lined shield on the eagle's breast and the eagle's wings being narrow and long (Brinckerhoff: 1976:15). A later version has a raised shield and the eagle having wide, short wings.

The other three buttons are two-piece, four-hole, white metal buttons. The smallest of the three is probably a 

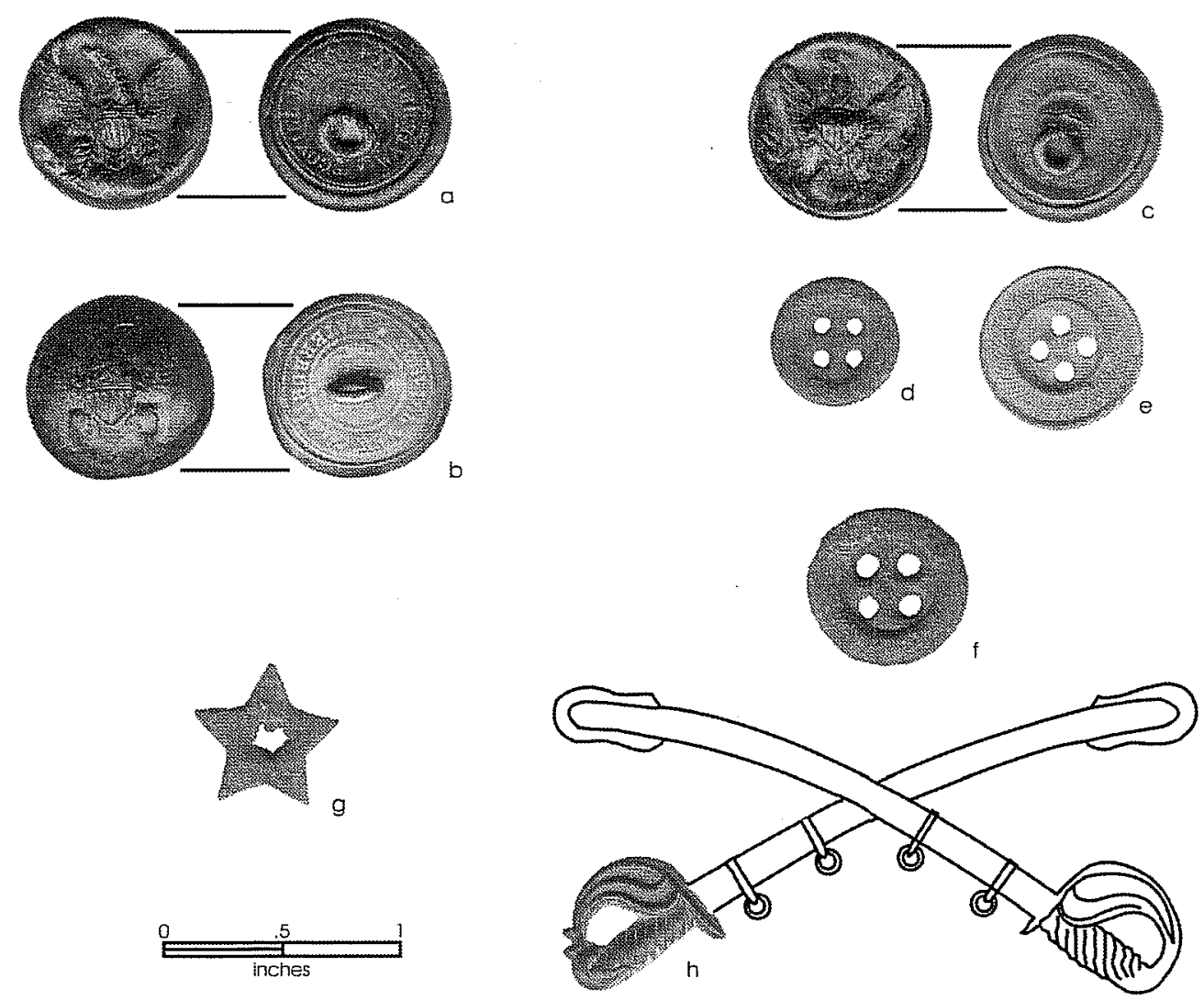

Figure 5-21. Personal artifacts. a-c) General Service uniform coat buttons; d) fly button; e, f) suspender or stable frock buttons; g) metal star stud; h) fragmented crossed saber, Cavalry branch insignia.

post-1885 fly button (Quartermaster General 1986:9495) (Figure 5-21d). It has a corroded surface and is in fair condition. The other two four-hole buttons appear to be post-1885 suspender or stable frock buttons (Quartermaster General 1986:94-95) (Figure $5-21 \mathrm{e}, \mathrm{f})$. One is in excellent condition showing the white metal, but the other is corroded. A small, and as yet unidentified, ornamental star stud was recovered (Figure 5-21g).

The last item in this category is a fragmented military insignia (Figure 5-21h). It is hollow-backed brass, lead-filled, with a crossed-sabers, cavalry branch insignia. This piece would have been worn on the front of a U.S. Cavalry hat, and dates to ca. 1872-1895 (Brinckerhoff 1976:7, 13; Cheek 1977). The approximate size of the insignia would have been $1 \frac{1 / 4}{4}$ inches high by $23 / 4$ inches wide. Brinckerhoff (1976:13) suggests that this smaller version of the insignia were worn from 1876 on, although lead filling began during the 1880 s. Therefore, the insignia fragment probably dates to the 1880s.

\section{Surface Features from the Private Property North of the Project Area}

\section{Maureen Brown}

In addition to the archaeological investigations within the U.S. 87 right-of-way fence line, CAR archaeologists received permission from the landowner and ranch manager to map and document surface features and artifacts in the adjacent ranch, north of the fence, in an area believed to be part of the original camp site. Artifacts were only recorded in the field log notes, mapped, or photographed, and nothing was collected from the property. Six features were identified and designated Features 14-19 (Figure 5-22). Two of the features (Features 15 and 18) were 


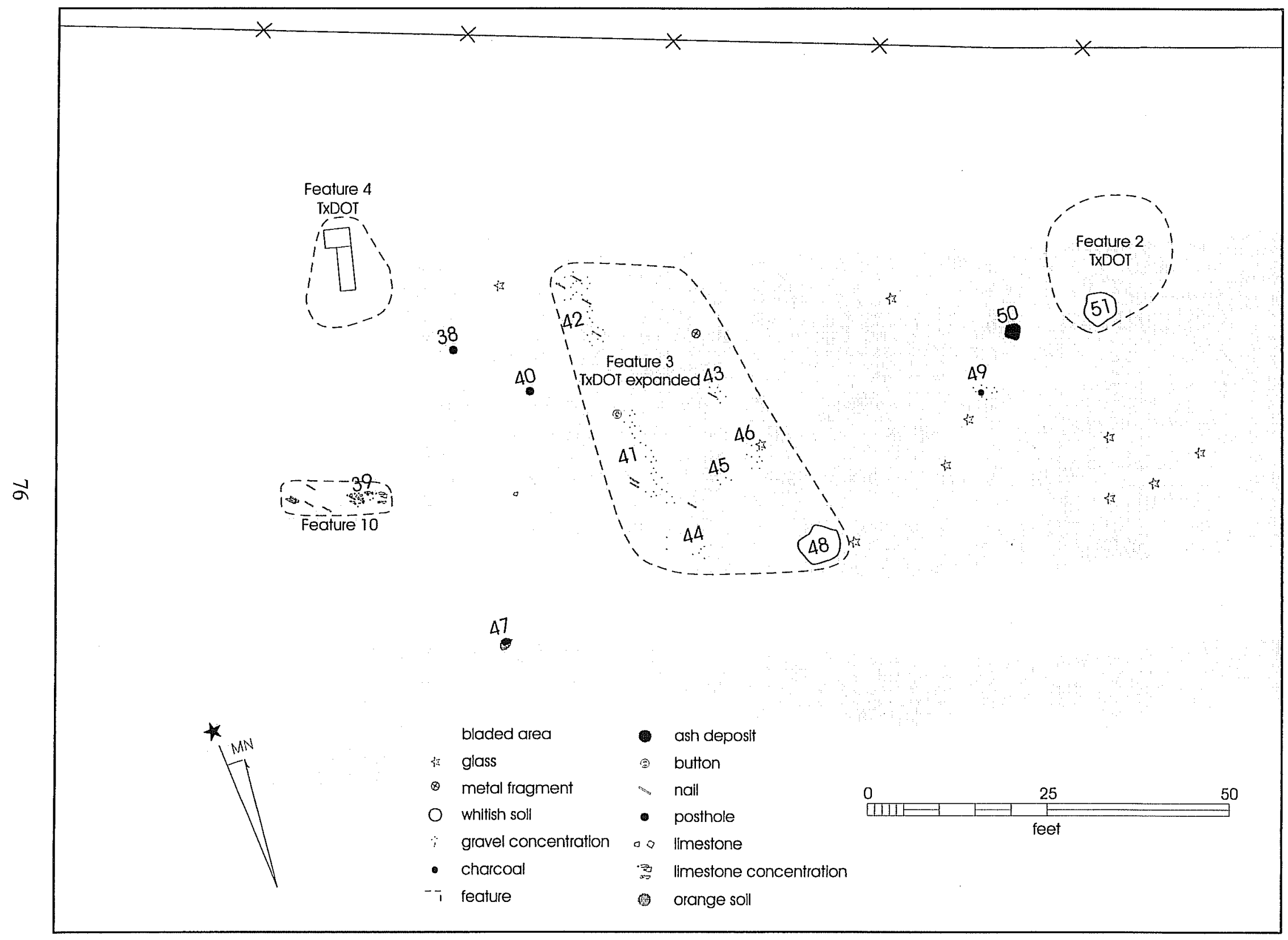

Figure 5-22. Plan map of surface features identified on the adjacent property. 
large limestone mounds, with well-shaped rocks forming obvious structural wall foundation alignments, visible on the surface. Four other types of features (Features 14, 16, 17, and 19) included a smaller non-mounded limestone rock foundation with obvious corners, a smaller mound of limestone with no obvious alignments, a rough circular limestone concentration with a depression in the center and scattered limestone around it, and an artifact concentration. Isolated artifacts were also found lying on the surface. Descriptions of Features 14-19 follow.

\section{Feature 14}

Feature 14 was flat on the surface and consisted of four clearly defined, roughly shaped limestone rock wall foundations (Figure 5-23). The wall foundations, which were $1.5 \mathrm{ft}$ wide, formed a $15-\mathrm{x}-15$ - $\mathrm{ft}$ square. No artifacts were discovered in association with the building feature.

\section{Feature 15}

Feature 15 was a large mound of limestone rock with remnants of wall alignments associated with a large building (Figure 5-24). The feature appeared to have a dividing wall in the center, separating the structure into two large rooms. Each of these rooms had an offcenter dividing wall that further separated the structure into a total of four rooms. The foundation was roughly square in shape and measured approximately $30 \times 30$ $\mathrm{ft}$. The wall width was ca. $2 \mathrm{ft}$. A tin can and bottle glass fragment were discovered on top of the feature. Other tin can fragments were located to the south and west, and an undecorated whiteware ceramic sherd was discovered near the northwest corner.

\section{Feature 16}

Feature 16 consisted of a limestone mound about 55 $\mathrm{ft}$ northeast of Feature 15. No pattern was discernible on the surface. It measured approximately $25 \mathrm{ft}$ (eastwest) $\times 22 \mathrm{ft}$ (north-south). No associated artifacts were visible on the surface.

\section{Feature 17}

Feature 17 was located about $8-10 \mathrm{ft}$ southeast of Feature 16 and was comprised of a concentration of bottle glass and undecorated whiteware ceramic sherds. The cluster of artifacts measured ca. $17 \mathrm{ft}$ in diameter.

\section{Feature 18}

Feature 18 consisted of a large mound of limestone with discernible wall foundations and corners (Figures 5-22, 5-25, and 5-26). It was located approximately $115 \mathrm{ft}$ east of the east wall of Feature 15. The foundations measured ca. $30 \mathrm{ft}$ (east-west) $\times 25 \mathrm{ft}$ (north-south). The walls appeared to be ca. $2 \mathrm{ft}$ thick. Like the other features, much large limestone rock rubble, representing wall fall, extended in and around the foundations. A fairly large concentration of aquacolored glass medicine bottle fragments were discovered on the surface in association with the south wall foundation of Feature 18. All of these are unmarked undiagnostic body sherds. A dense concentration of 19 of these sherds was near the southeast corner of the structure.

\section{Feature 19}

Feature 19 was approximately $40 \mathrm{ft}$ north of Feature 18 and was comprised of limestone rocks in a roughly circular pattern with a depression in the center (Figure 5-22). The outer edges measured ca. $9 \mathrm{ft}$ in diameter. A large scatter of limestone rocks extended around the feature and south toward Feature 18. It was difficult to tell whether this scatter represented a separate structural feature or if it was a part of Feature 19. Adjacent to the southern edge of Feature 19 was a ca. 24-x-18-inch limestone slab with an incised, crossshaped mark (Figure 5-27). Whether the cross was carved by a person or is a natural phenomenon was not determined.

Several small clusters of isolated artifacts, not in any obvious association with any features, were discovered on the surface. These mainly consisted of metal can 


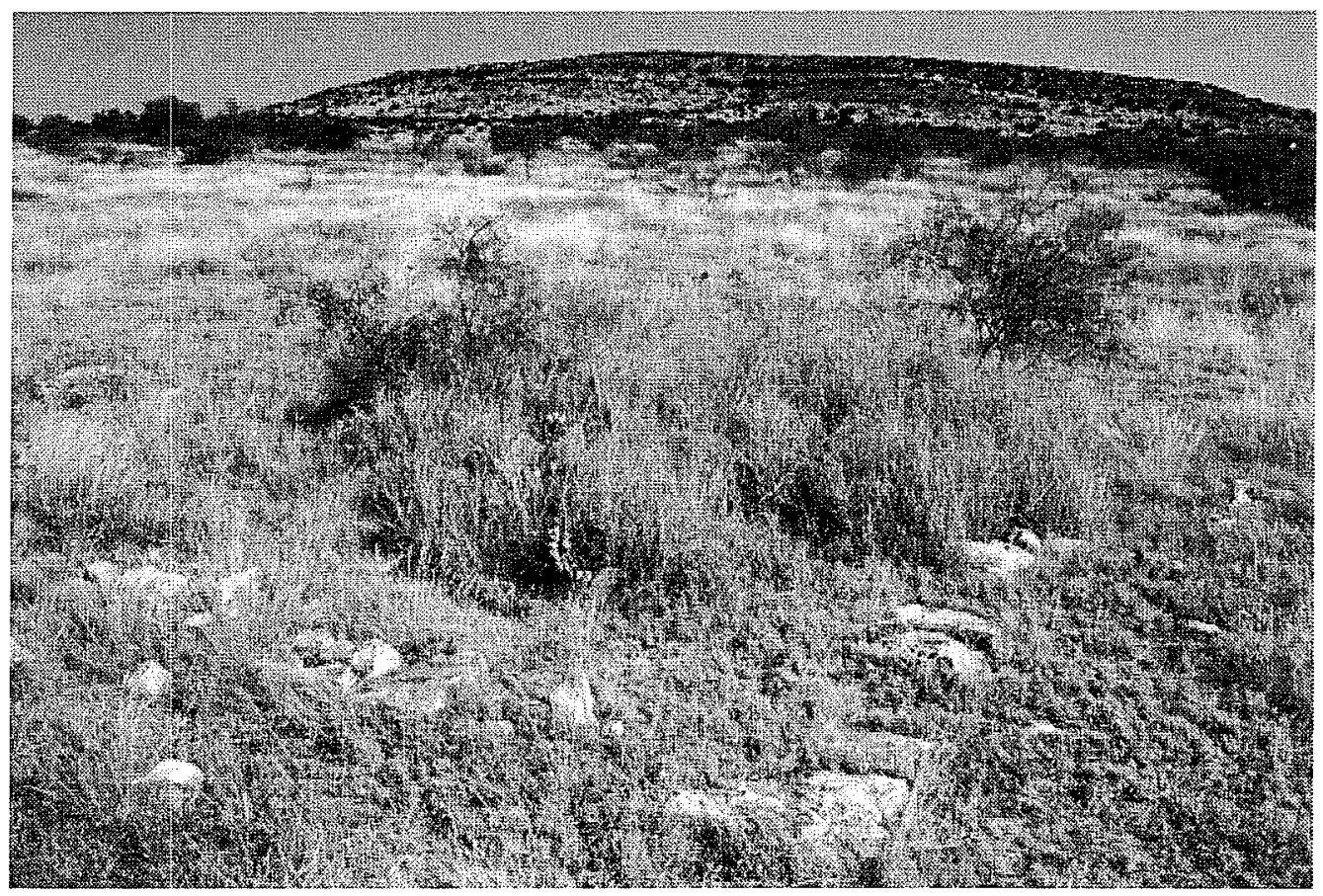

Figure 5-23. Feature 14, southeast corner

foundation (looking northeast).

Figure 5-24. Feature 15, center wall foundation

(looking west).

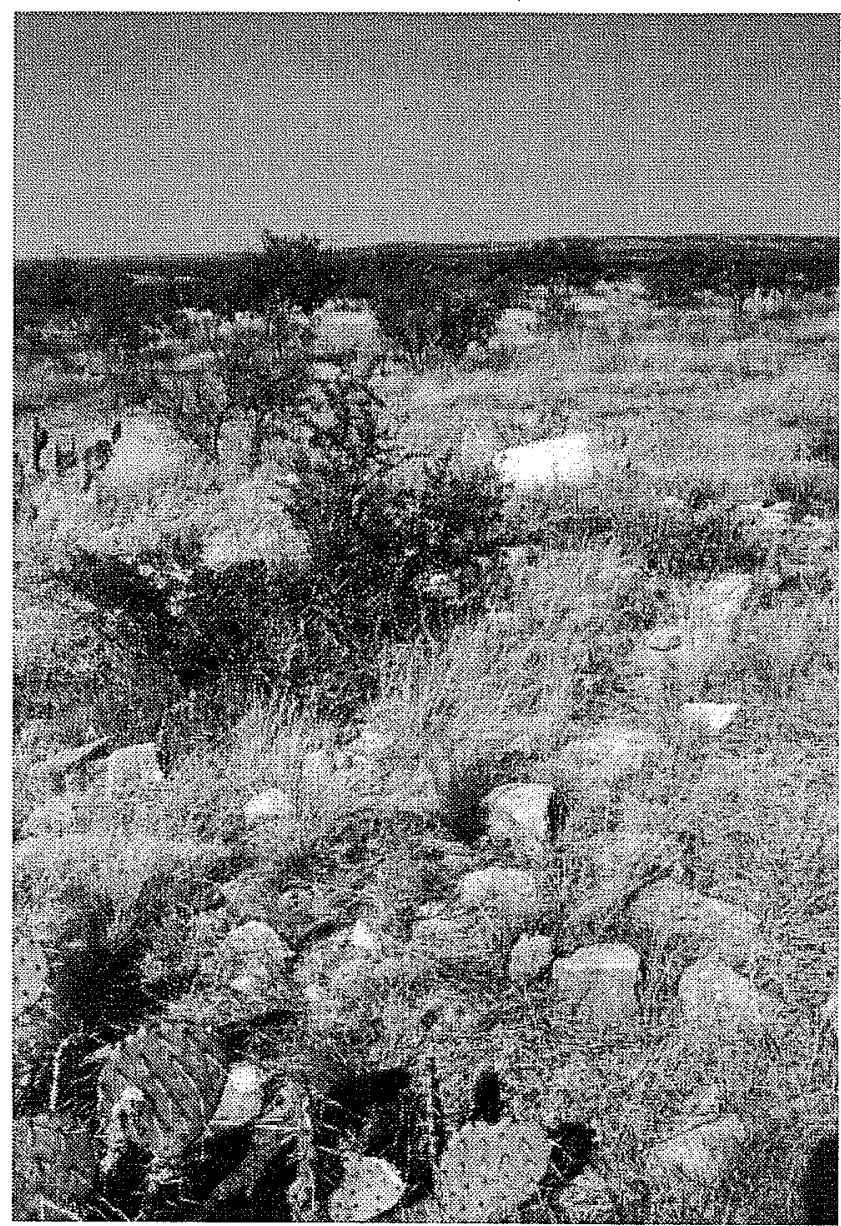




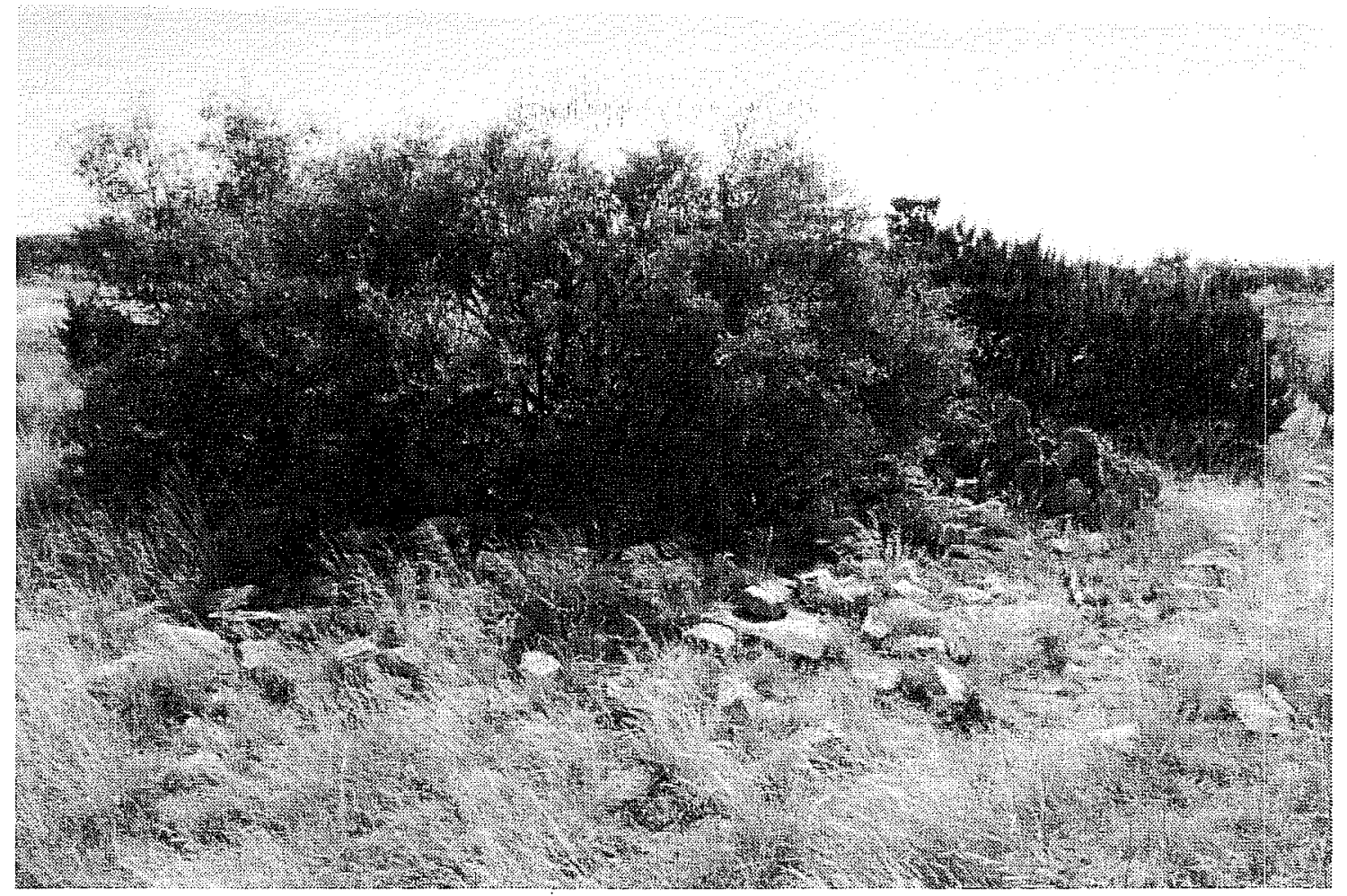

Figure 5-25. Feature 18, large limestone mound (looking northeast).

fragments and brown and aqua-colored bottle glass fragments.

In addition to the above features identified and recorded, the ranch manager drove CAR staff to a portion of the property where supposedly two Buffalo Soldier graves are located. The location was north of the camp site toward the base of McIntyre Butte. On the surface were two mounded areas, separated by a distance of ca. four feet, with a few fairly large unmarked limestone slabs (Figure 5-28). These were oriented

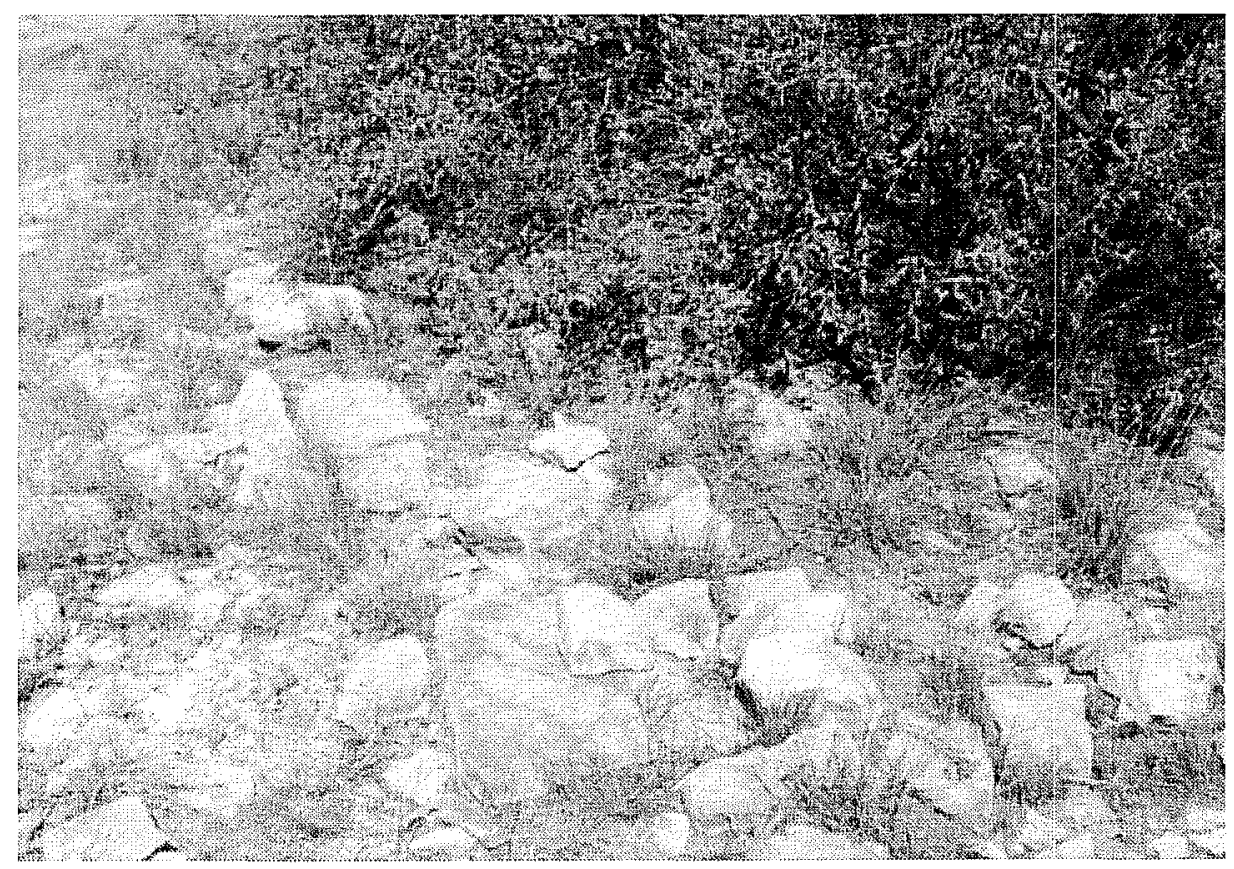

Figure 5-26. Feature 18, southwest corner foundation (looking east, southeast). roughly in a north-south

direction. The northern mound was about $8 \times 6 \mathrm{ft}$, with a 20-x-22-inch limestone slab. The southern mound measured about $14 \times 9 \mathrm{ft}$, with a ca. 22-x-32-inch slab and another stone measuring $9.5 \times 10.5$ inches. Also on the surface east of this mound was a cut nail and a rusted old tin can. There was also a patch of calichelike rubble near the area that measured ca. $2.5 \times 4 \mathrm{ft}$. 


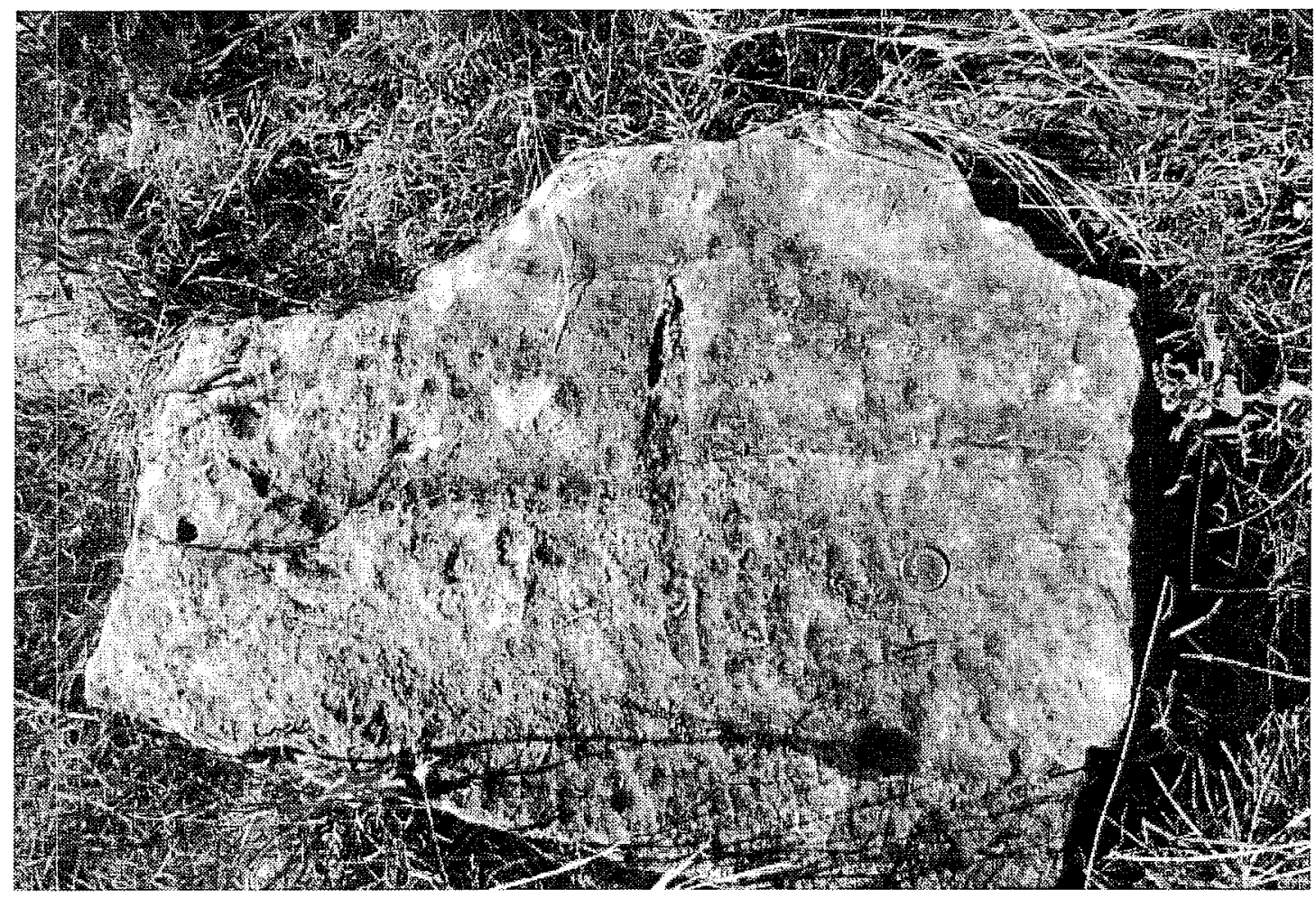

Figure 5-27. Limestone rock with possible incised cross-shaped mark located near Feature 19.

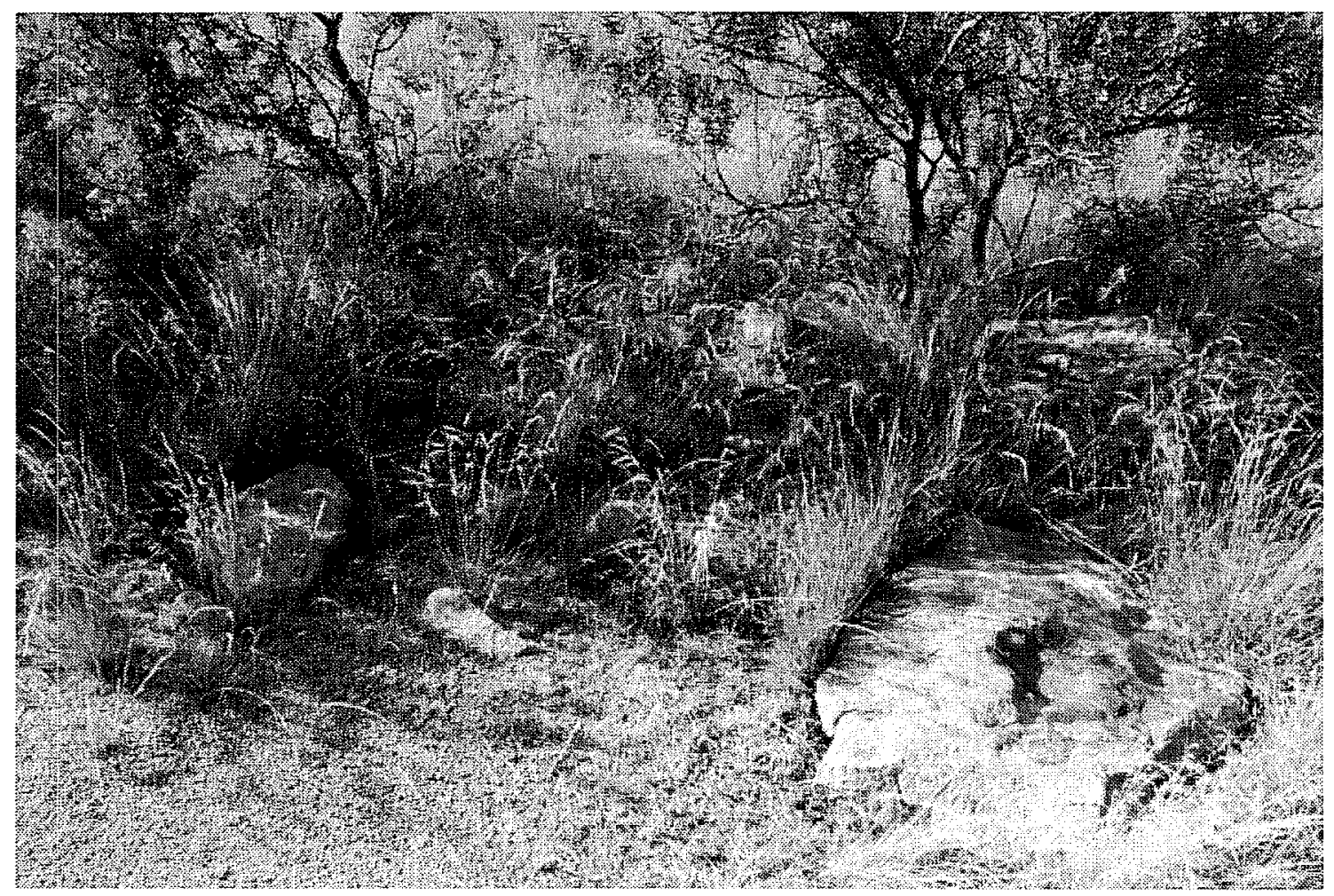

Figure 5-28. Limestone slabs in area where two soldiers may have been buried. 


\title{
Chapter 6: Conclusions and Interpretations
}

\author{
Maureen Brown, Anne A. Fox, Bruce K. Moses, José E. Zapata, and \\ C. Britt Bousman
}

\section{Introduction}

Conclusions and interpretations of archival and archaeological investigations of Camp Elizabeth are presented here in a format that addresses the main research issues presented in Chapter 3. The results are compared together with other archaeological and historical sites within the region and elsewhere. Research issues related to Camp Elizabeth include the site occupation and chronology, specifically who used the site and when; the function of the site, site features, and the activities that took place at Camp Elizabeth and at other similar military outposts; and the architectural/spatial layout of the site as compared to other military forts and outposts. The site selection as it pertains to the environment of the project area and the military's utilization of the natural resources is also included in this chapter.

\section{Occupation and Chronology}

\section{Maureen Brown and José E. Zapata}

Archival investigations found no substantiating evidence placing the Texas Rangers at Camp Elizabeth. The documents indicate the occupation of the site begins with its use by the U.S. military. The Fort Concho Scouting Reports contain the first recorded evidence of use of the camp. This evidence indicates the subpost at the Head of the North Concho, or Camp Elizabeth, was possibly used as a stopover or temporary way station beginning in August 1873. At this time Captain Corney and companies A and G, 9th Cavalry (two officers and 59 enlisted men), marched from Fort Concho en route to the Head of the North Concho (River) (FC SR:67). However, there was no mention of a subpost or the site being used as a camp. For that matter, they may have camped anywhere along the head of the river. The first report of its use as a "supply camp" was found in an August 1879 report of activities authored by 1st Lieutenant Ward, 10th Cavalry. Ward's report was addressed from the "Head of the North Concho, Texas." The report stated that Ward, 10 enlisted men, and five citizens left the supply camp (FC SR:307). There was no mention of the total number of individuals at the camp at this time. The second mention of 10th Cavalry troops leaving "Supply Camp at the Head of the North Concho" was reported by Captain Keyes, September 1879 (FC SR;312-313). Apparently the camp at the Head of the North Concho became an official subpost when building commenced on it and two other subposts of Fort Concho-Camp Charlotte and Grierson Springs. These operations were initiated under Special Order No. 29 of November 1879 and Special Order No. 6 of March 1880, from Headquarters, District of the Pecos (FC SR 319,329). Beginning March 23, 1880, the camp at the Head of the North Concho was occupied by the military for a 2.5-year period ending September 23, 1882 (FC SR:329) (Table 4-4). A review of the available scouting reports and post returns indicates that "Camp Elizabeth" was intermittently occupied by Companies D, F, G, L, and M, 10th Cavalry; and Companies $C$ and F, 16th Infantry. Reports suggest the 10th Cavalry was at the camp on two different occasions during 1879 , and then on eight different occasions during the $1880-1882$ period. During the later period, five different units of the 10 th were listed. Company M, 10th Cavalry, under Capt. Norvell, was listed at the Head of the North Concho for approximately 11 months during three separate periods. The largest number of troops listed at the camp at any one time was 146 enlisted men under Capt. Hayes, Troop D, 10th Cavalry. Therefore, the records strongly indicate the presence of the 10th Cavalry Buffalo Soldiers at "Camp Elizabeth" during the majority of the period it was occupied, while the 16th Infantry Anglo troops were located there two out of the 10 recorded instances. In addition to the troops 
temporarily stationed at the camp, the documentary evidence suggests that other individuals visited. Capt. Norvell's report in October 1880 mentioned that "traders and other Camp followers" would visit the camp and that "every pay day the Camp was besieged by traders and gamblers"(FC SR:329-332). Also a Dr. Finley and his wife were reported to have stayed at the camp some time in October 1882 (FC MFR:5).

Results of the artifact analysis corroborate the archival evidence. A small sample of lithic debitage suggests a possible prehistoric component. These appeared to be concentrated in the western half of the project area (see below). None of the material was diagnostic, and therefore no occupation period could be established. However, the historic cultural remains strongly suggest a military presence at the site during the $1880 \mathrm{~s}$. The artifact assemblage used to establish the site chronology included nails, bottle glass, buttons, maker's marks, a marble, and an insignia fragment. Only machine-cut nails, no later wire nails, were recovered. These date to $\mathrm{ca}$. 1838-1890. The complete beer bottle, marked "IG Co" representing the Ihmsen Glass Company, dates to ca. 1870-1895. The swirl glass marble dates to ca. 1838-1910. The three General Service coat buttons with the stamped eagle facing left date to ca. 1855-1884. The other buttons were post-1885, but these may have also been made earlier (C. Haecker, personal communication 1998). The cavalry insignia fragment dates ca. 1880 s because it is of the lead-filled brass type. The presence of the post-1870 bottle and the post-1880s insignia along with the other artifacts within this assemblage dates the site to the 1880s. Surprisingly, most of the artifacts recovered appear to date to the same general period. The site did not contain earlier remains (aside from the lithics) or even much later-period roadside debris. However, this date is based on a small number of timediagnostic artifacts.

In addition, the artifacts confirm the military occupation of the site. The artifacts that have been used to distinguish a military frontier site from a nonmilitary site as suggested by South (1977:175-176) include his Class 42, Military Objects. These objects were composed of military insignia, artillery objects, swords, bayonets, etc. Military buttons should be included in this category. The military artifacts at
41ST111 as suggested above, included military buttons, a cavalry-type cartridge and bullet, and a cavalry insignia fragment. Although the sample is small, the artifacts recovered from Camp Elizabeth compare with South's military site.

Although the artifact assemblage indicates a military presence at Camp Elizabeth, the evidence does not support the presence of the Texas Rangers at the site. Likewise, the small number of diagnostic artifacts, the lack of ceramic and faunal remains, and the absence of deep midden deposits, made it impossible to do the kinds of intra- or inter-site ethnic and social status comparisons outlined in the research issues (see Chapter 3). There may be several reasons for not finding ceramic remains during the investigations. First, only a sample of the right-of-way was investigated, and this represented only a fraction of the entire camp site. Within the area investigated no large domestic middens were identified that may have included ceramic remains. Second, ceramic remains were observed on the surface within the private property near the officer's quarters, which may then have more to do with rank. The investigations were located primarily within the enlisted men's campground area where no ceramics were found. It is possible that on these temporary subposts enlisted men used standard issue metal mess kits instead of ceramics. A third possibility may have to do with site deposition. The military camp may have required its men to discard their trash in certain locations which may have been outside the investigated area. A fourth possibility is that ceramics may have been picked up illegally from the surface in the area of the right-ofway by relic hunters.

Therefore, the military presence was established, but from the recovered artifacts we were unable to identify a definite "Buffalo Soldier" component. There are no known military artifact remains that would identify a "Buffalo Soldier" from other enlisted men artifacts. The closest thing thus far that would identify the presence would be a cavalry insignia with a "10" in this case. The archival data suggested a strong presence of the 10th Cavalry, who were primarily made up of African-American troops, excluding a few officers, up to 1882 . The ca. 1880 s cavalry insignia fragment, 
although lacking a " 10 ", further helps to confirm the presence of the cavalry at the site.

\section{Function and Activity}

\author{
Maureen Brown, Bruce K. Moses, \\ Anne A. Fox, and C. Britt Bousman
}

\section{Function of Subposts}

Subposts were an integral part of the system of Texas forts, acting as intermediate stations. At first, they functioned primarily to provide couriers between the posts, rather than for offensive or defensive purposes. Many started as temporary camps for ranging companies who were sent out to scout for signs of Indians. These scouts, generally made up of one or two companies of cavalry and a few officers, were known to cover as much as 300-500 miles and to be out for three or four months. They traveled an average of 25-30 miles a day, camping each evening at a different location. By 1880 , some of the earlier camps had been abandoned, leaving the Camp at the Head of the North Concho just one of three remaining. It was at this time that companies began to be stationed at the camp for periods of time, which would have required construction of more substantial buildings and provision for servicing and housing a larger group of men.

\section{Military Activities}

Numerous activities were required of the men stationed at both the forts and the subposts. First and foremost, of course, was their responsibility to patrol the frontier and occasionally to escort travelers and wagon trains. In addition, they had to do the chores required to support their company, which would have included pitching tents, cleaning and maintaining the camp, and cutting and hauling hay for the horses. At times the men were also required to do construction work at the camp-building outbuildings and service buildings such as blacksmith shops and other workshops. The Regulations concerning Barracks and Quarters for the Army of the United States [RBQA] (1860:5) states, "As far as possible, the materials for building will be provided and the work executed by the labor of the troops; though, if absolutely necessary, . . . a limited number of head mechanics, particularly a competent carpenter, may be hired." In the Fort Concho Scouting Reports (FC SR:320-321), Captain Gray of Company $\mathrm{K}, 25$ th Infantry, reported in May 1880 that during the company's stay at Grierson Springs they were "employed in building, escort, and scouting duty." "A stone corral and stables with the capacity for horses was constructed with a thatched roof. A guard house was constructed also, built of stone with the roof thatch, it contains two rooms each twelve feet square in the clear" (FC SR:320-321).

Although masons and other experts were often hired from the surrounding community, it was "the duty of every officer charged with the erection of buildings, the immediate commander, and the authority acting on estimates, to acquaint themselves thoroughly with the established plans and estimates, in order that the necessary orders may be given advisedly and the work executed properly and with due economy" (RBQA 1860:5). Building materials varied, as suggested in the Army regulations, "the various buildings required at military posts will be made of frame, stone, bricks, earth, or logs, depending on climate, the cost of building, and the durability required. The same considerations will determine whether they shall be roofed with shingles, tin, tiles, earth, or thatch; and whether the floors shall be of boards, stone, brick, or earth" (RBQA 1860:5). A report from Grierson Springs in October 1880 included a requisition for "two barrels of cement, one keg of 10D nails, and as much lime as can be hauled" (FC MFR:5). Another important responsibility of the troops was to build and maintain roads and trails in the vicinity.

\section{Archaeological Evidence For Function and Activity}

Archaeological evidence for the function of Camp Elizabeth and its associated activities include interpretations of the artifact distributions and the artifact presence and absence results as compared to the site features. Interpretations of individual site features (Feature 1-19), include comparisons with 
other sources to provide supportive evidence to these conclusions.

\section{Artifact Distributions}

The distribution of artifacts was inspected using two slightly different methods. First, all historic artifacts collected during excavations were used to calculate densities (number of artifacts/ $\mathrm{ft}^{3}$ ) for each unit. These densities were then plotted along with identified features within the highway's right-of-way containing excavation units (Figure 6-1). Individual surface artifacts recorded during the survey were not used in density calculations. Second, the artifacts were divided into functional classes as discussed in Chapter 5, and the presence/absence of these distributions were plotted on the same scale as the density.

\section{Density Distribution}

Although some of the mapped density clusters correspond well to the distribution of features across the eastern half of the grid, others are not as definitive (Figure 6-1). An extremely high density cluster in the southeast corner corresponds to Feature 1. Artifacts clearly cluster in a crescent pattern across the south and western portions of this feature (Figure 6-2). In part, this high density can be explained by the number and size of excavation units placed around this feature as opposed to the limited excavations in other areas. However, this factor cannot be completely responsible for the presence of these high densities. The highest densities of all of the excavated units occurred in U73 and $\mathrm{U} 74,\left(0.022\right.$ and 0.018 artifacts $/ \mathrm{ft}^{3}$ respectively), both of which were $20 \times 20$ inches.

A second area with significantly high densities is located approximately $150 \mathrm{ft}$ northwest of Feature 1 . This density cluster forms a bilobal pattern which generally corresponds to Features 3, 4, and 10. A third density concentration in the northwestern portion of the grid is associated with U33. This concentration corresponds with a scattering of glass on the surface that may represent a single bottle break. Densities decrease dramatically toward the western portions of the grid and do not appear to correspond with features in that area.

\section{Presence/Absence Distribution}

Figures 6-3 and 6-4 show the presence/absence distribution of the various artifact groups. Activityrelated artifacts (such as cartridges, a marble, and a piece of writing slate) are dispersed in two distinct areas of the eastern half of the grid. The presence of artifacts from this category also occurred in U87 within Feature 4 . No activity-related items were recovered from units in the western half of the grid. Personal items are scattered within three units near the center of the grid. One cluster occurs in the northern portion of Feature 4 and contained military buttons and a fragmented cavalry insignia. Interestingly, personal items were completely absent from the extreme western and eastern portions of the grid.

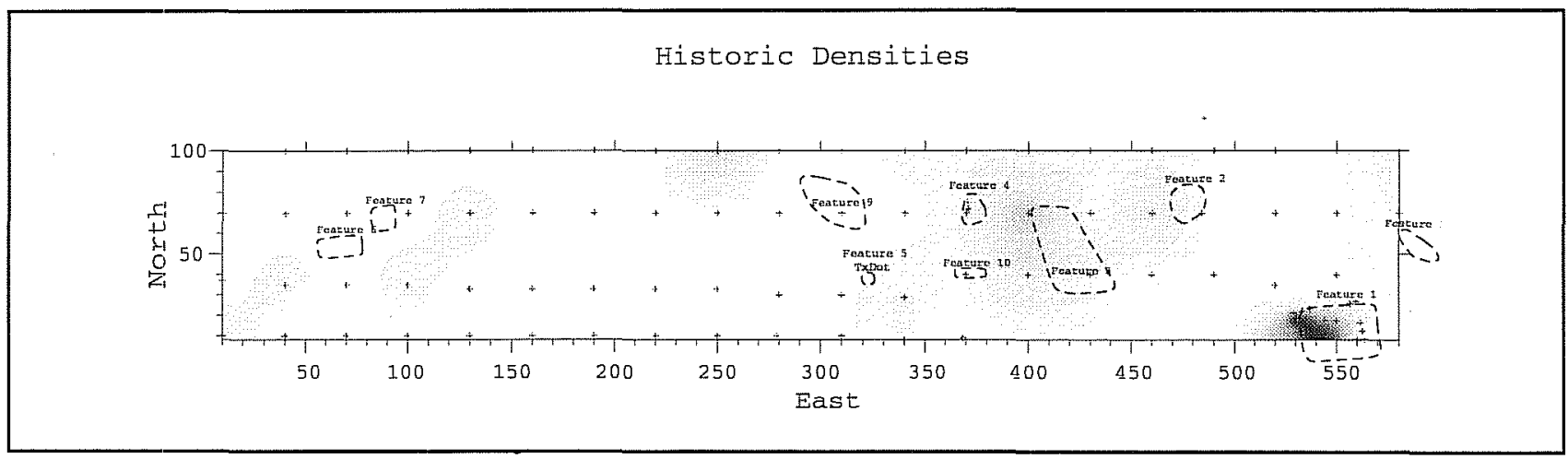

Figure 6-1. Historic artifact densities, Units 1-89. 


\section{Feature 1 Artifact Density}

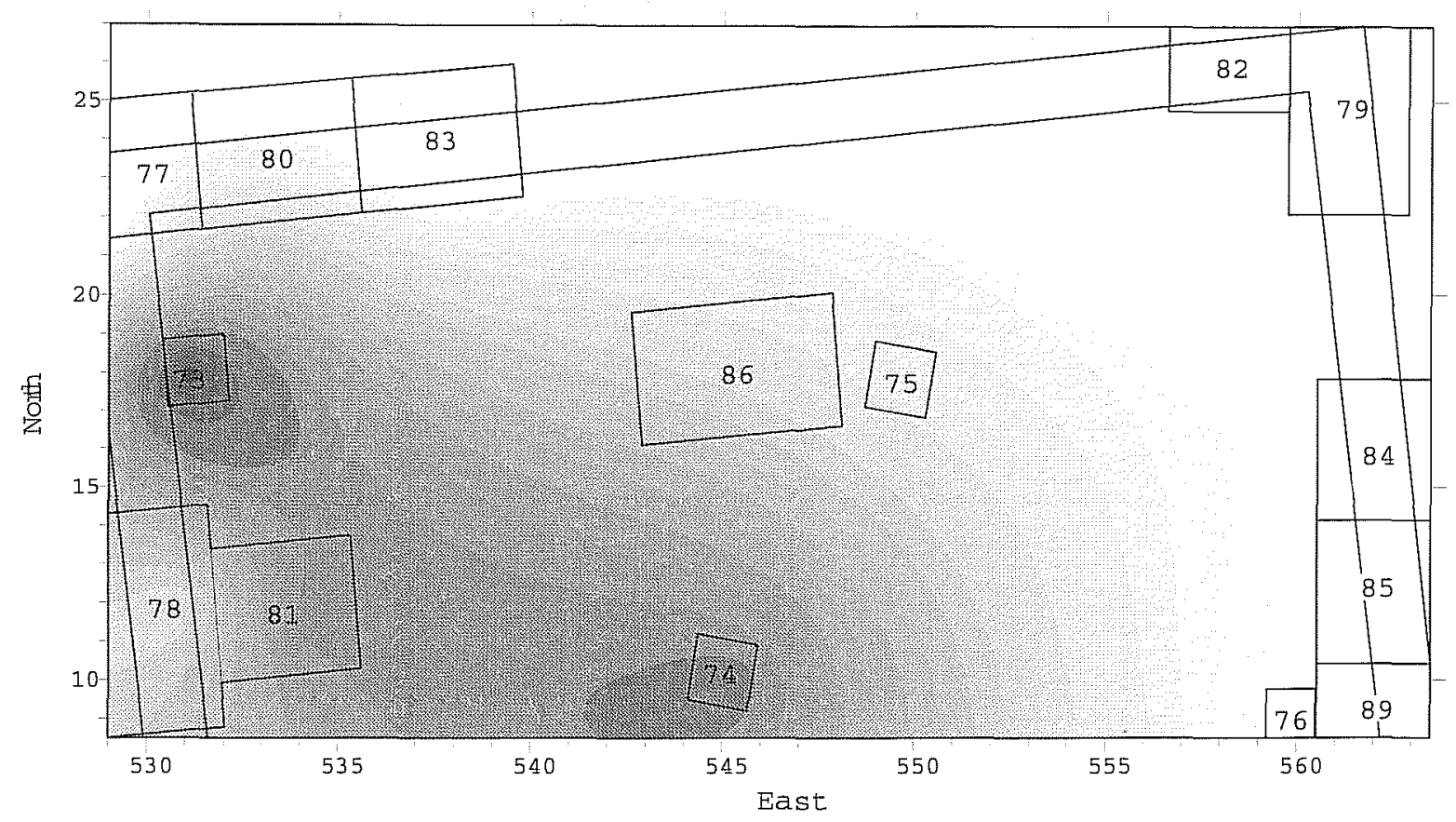

Figure 6-2. Historic artifact densities, Feature 1.

Construction-related artifacts are scattered across the eastern half of the tested area and correspond to Features 1 and 3. A single cut nail is the only construction-related item recovered from excavations in the western portion of the grid. Workshop-related artifacts are virtually absent from the western twothirds of the site. Instead, they are primarily concentrated around Feature 1 in the southeastern corner of the grid and in U87 in Feature 4.

Isolated domestic artifacts are widely spread across central and eastern portions of the grid. Several units in Feature 1 contained artifacts from this category. One of the plotted clusters reveals a large area of domestic artifacts corresponding to Feature 3 and Feature 4. Faunal remains are primarily concentrated in the eastern quarter of the site and principally within Feature 1 units. One other isolated patch of faunal material occurs at the very southwestern corner of the grid in U4.

Miscellaneous artifacts also tend to cluster across the eastern half of the grid. The heaviest concentration of units bearing miscellaneous artifacts occurs in the immediate area of Feature 1. Another small cluster is formed by artifacts from U59 and U60, roughly corresponding to Feature 2.

Finally, prehistoric lithic artifacts are most frequent in the western half of the site and decline in frequency toward the east. For the most part, these patches of lithic artifact do not directly correspond to any of the historic presence/absence plots, and the prehistoric artifacts reflect an unrelated occupation.

\section{Interpretation of Site Features}

Archaeological investigations identified Features 119 at the site of Camp Elizabeth (Figure 6-5). Thirteen features (Features 1-13) were identified through excavations within the immediate project area rightof-way, and six surface features (Features 14-19) were identified north of the project area within the adjacent property. These results can be compared with the diagram of Camp Elizabeth as remembered by W. F. 


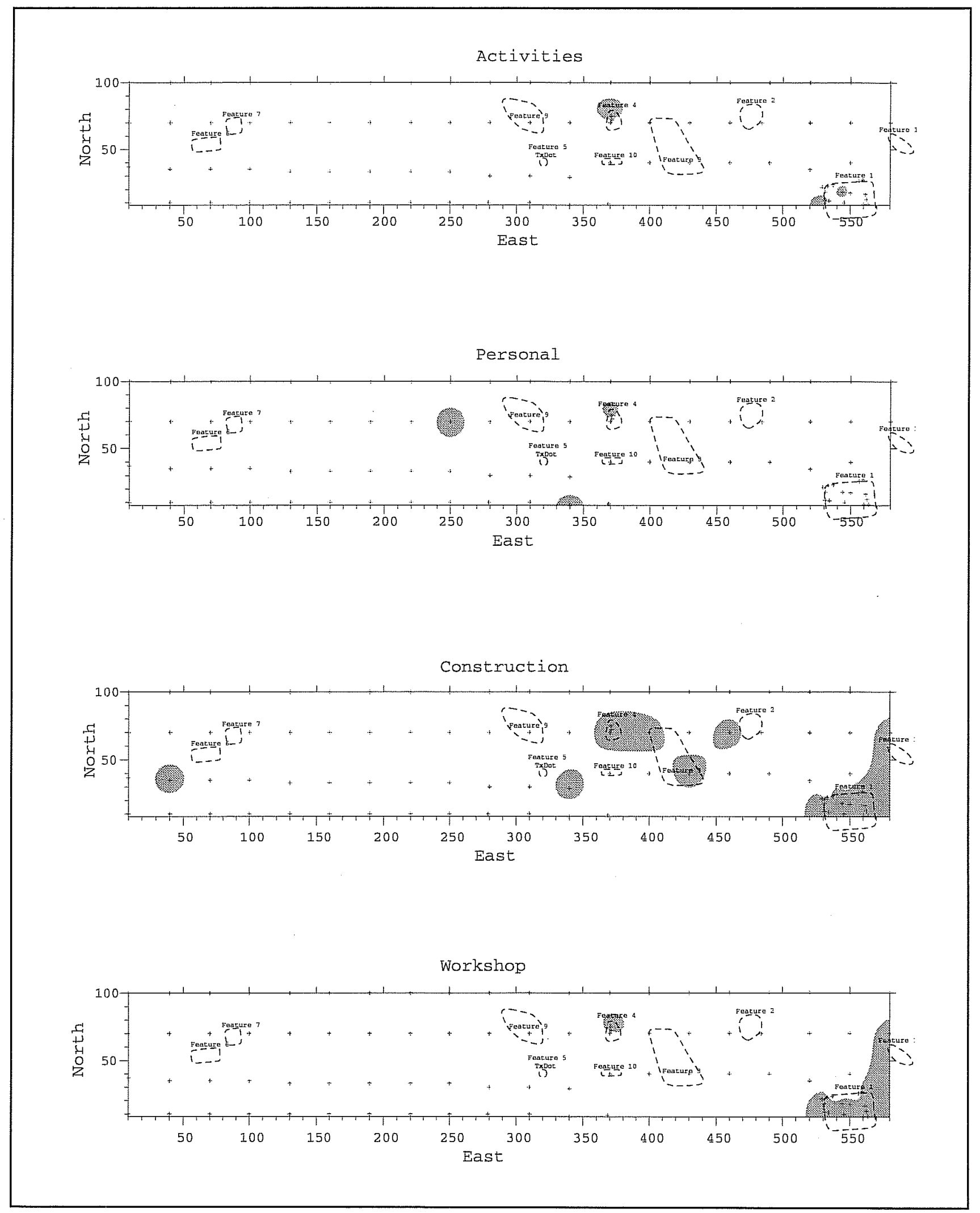

Figure 6-3. Presence/absence distribution maps. 
Domestic

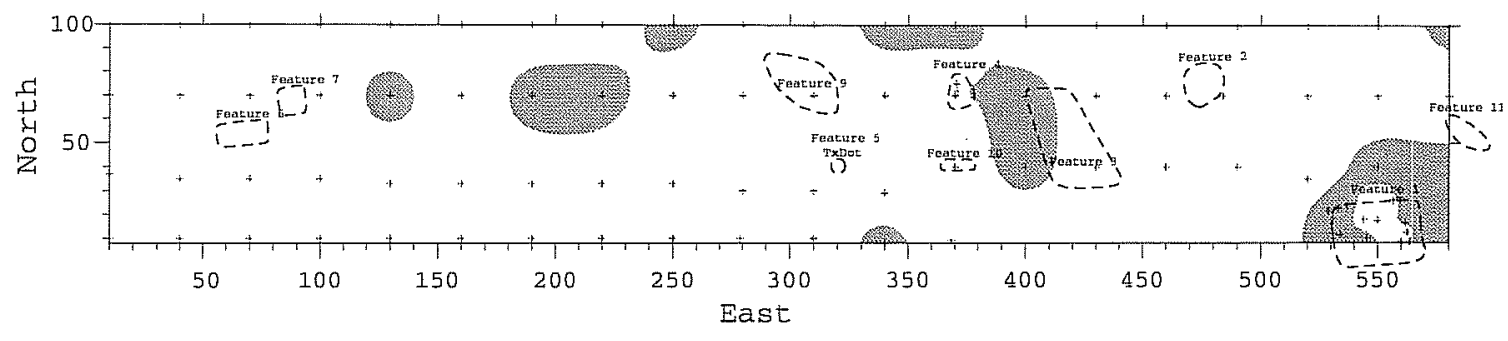

Faunal

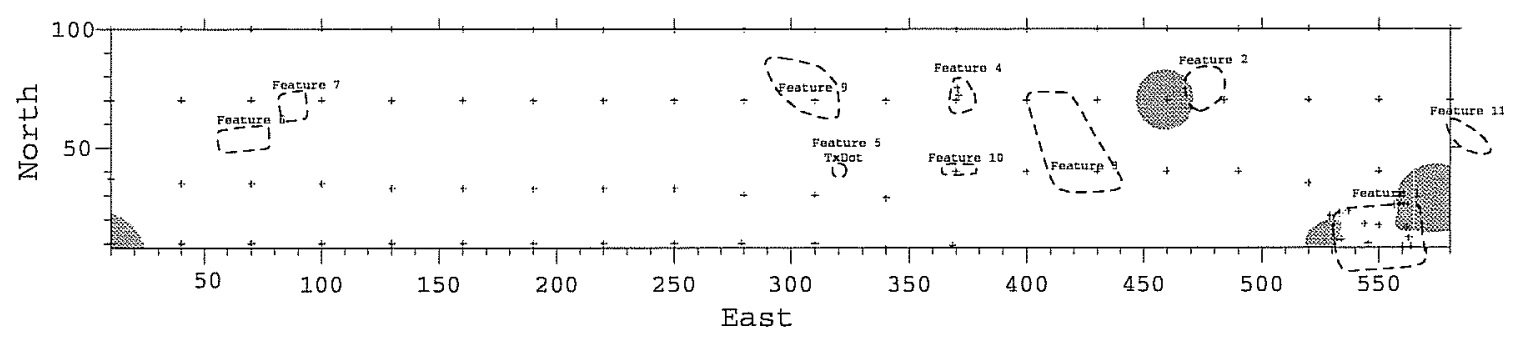

Miscellaneous

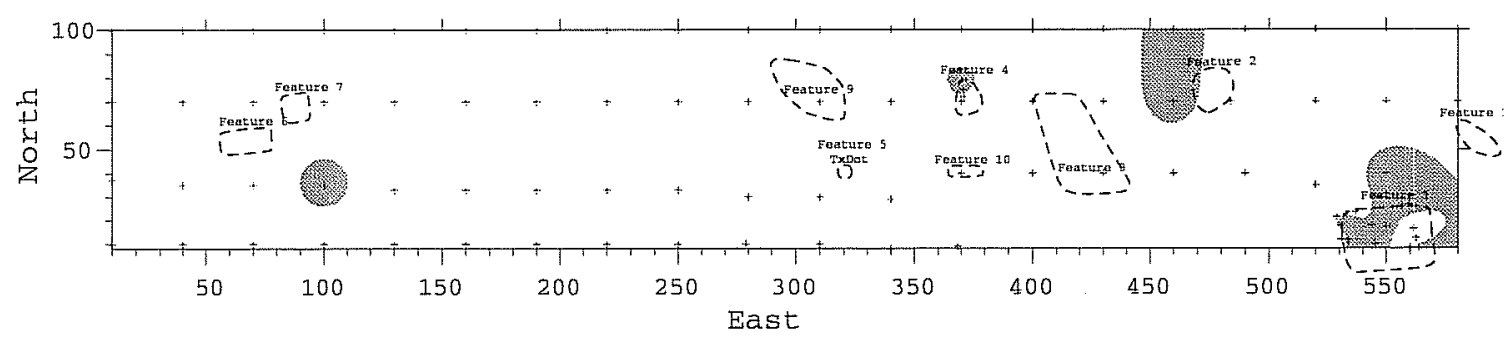

Lithic Artifacts

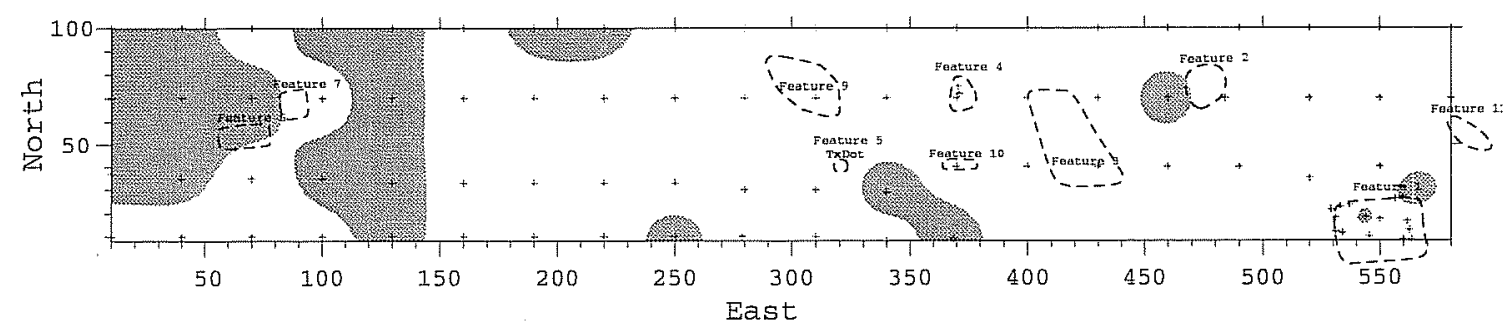

Figure 6-4. Presence/absence distribution maps. 


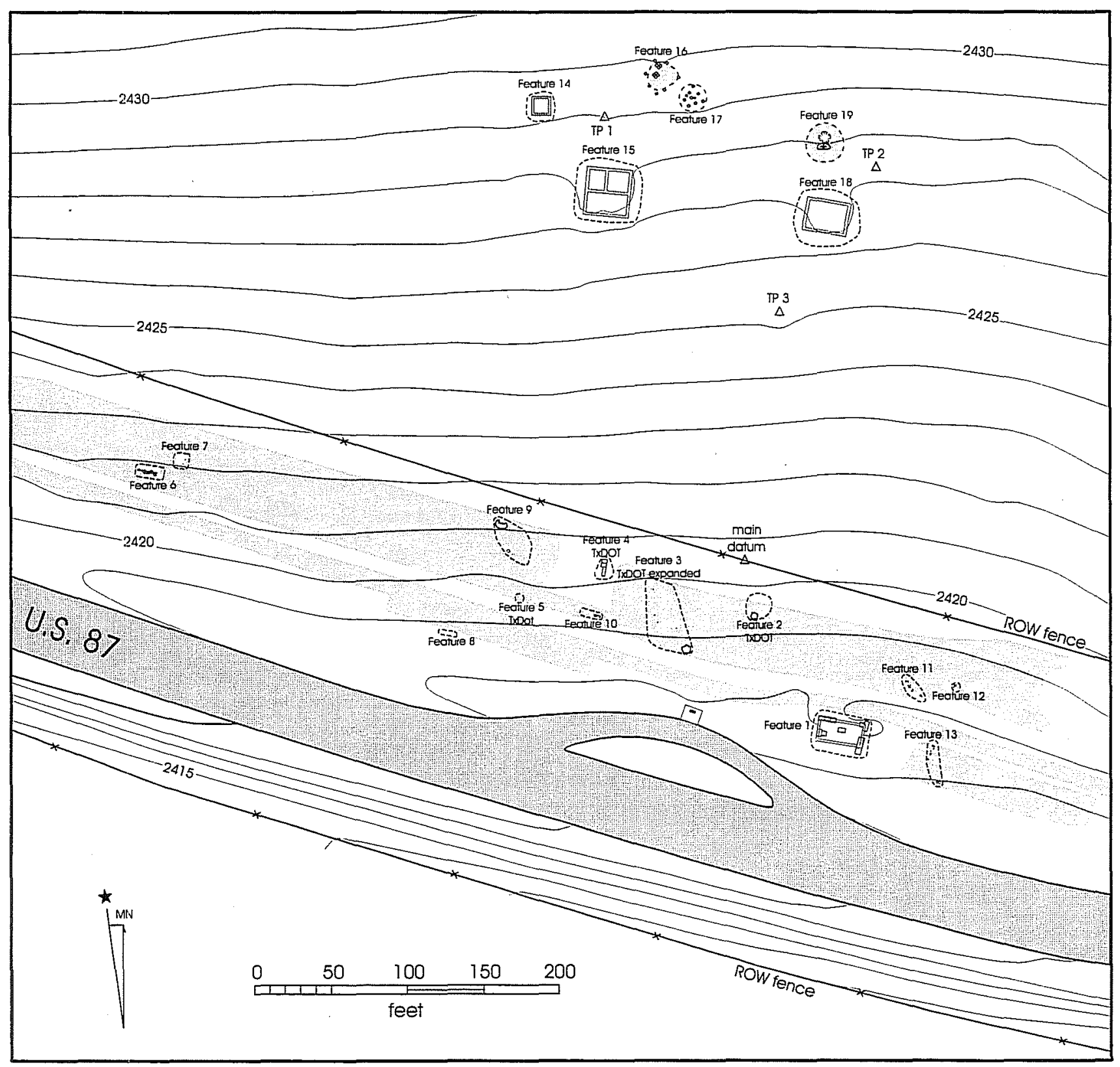

Figure 6-5. Features 1-19. Features 1-13 in project right-of-way, Features 14-19 in adjacent property.

Kellis, a local Sterling County surveyor, in Daniels (1976) (Figure 6-6). Kellis diagram includes functional captions for each structure (i.e., farrier's shop, hospital, officer's quarters, etc.) and the various functional areas of the camp (i.e., camp ground, parade ground). This information is compared with results and interpretations of the site features.

\section{Feature 1: The Farrier Shop}

When the Camp at the Head of the North Concho was first established, there would not have been a farrier stationed there. The first companies to camp there would have had portable forges that traveled with them on specially equipped carts (Kevin Young, personal communication 1998; Ordnance Department U.S.A. 1874:Plates 10-13). It would not have been until the first military units were stationed there in 1880 that 
there was need for a farrier's shop to service the large number of horses required at a permanent post.

Although the plan of the camp (Figure 6-6) identifies Feature 1 as the farrier's shop, the army generally used the term smith (short for blacksmith) to refer to the man who worked there. While a blacksmith ordinarily did a great variety of ironwork in addition to being a farrier, the smith on a cavalry post dealt primarily with horseshoeing. As the army travels on its stomach, the cavalry travels on the feet of its horses, which must be kept in good condition. The farrier's shop can be expected to contain artifacts such as horseshoe nails, worn-out horseshoes, and discarded cuttings created in fitting the shoes to the individual horse.

The heart of a smith's shop was the forge, a large cubic structure of brick or stone which held a hot fire at waist level. Next to the forge was a large heavy iron anvil mounted on a section of log set securely into the ground. The iron for the horseshoe was heated red hot on the fire, then beaten into the proper shape on the anvil. This process was necessary whether the smith was working with a preshaped horseshoe, or starting from scratch with a length of bar iron.

On first examination, it seemed that there was no sign of a forge in Feature 1. However, careful study of the photographs, the plan map locating the excavation units, and the artifact density diagram (Figure 6-2) indicates that a stone forge was probably located in the northeast corner of the shop. While there are stones scattered throughout, a number of larger, heavier stones were found outside that corner. The location of these stones and the concentration of artifacts having to do with horseshoing in the southwest quadrant of the building reinforce this interpretation. Since it was not necessary for the forge to extend into the floor of the building, it could possibly have left no trace when the stones were disturbed during the stone robbing that went on at the site in the late-nineteenth century.

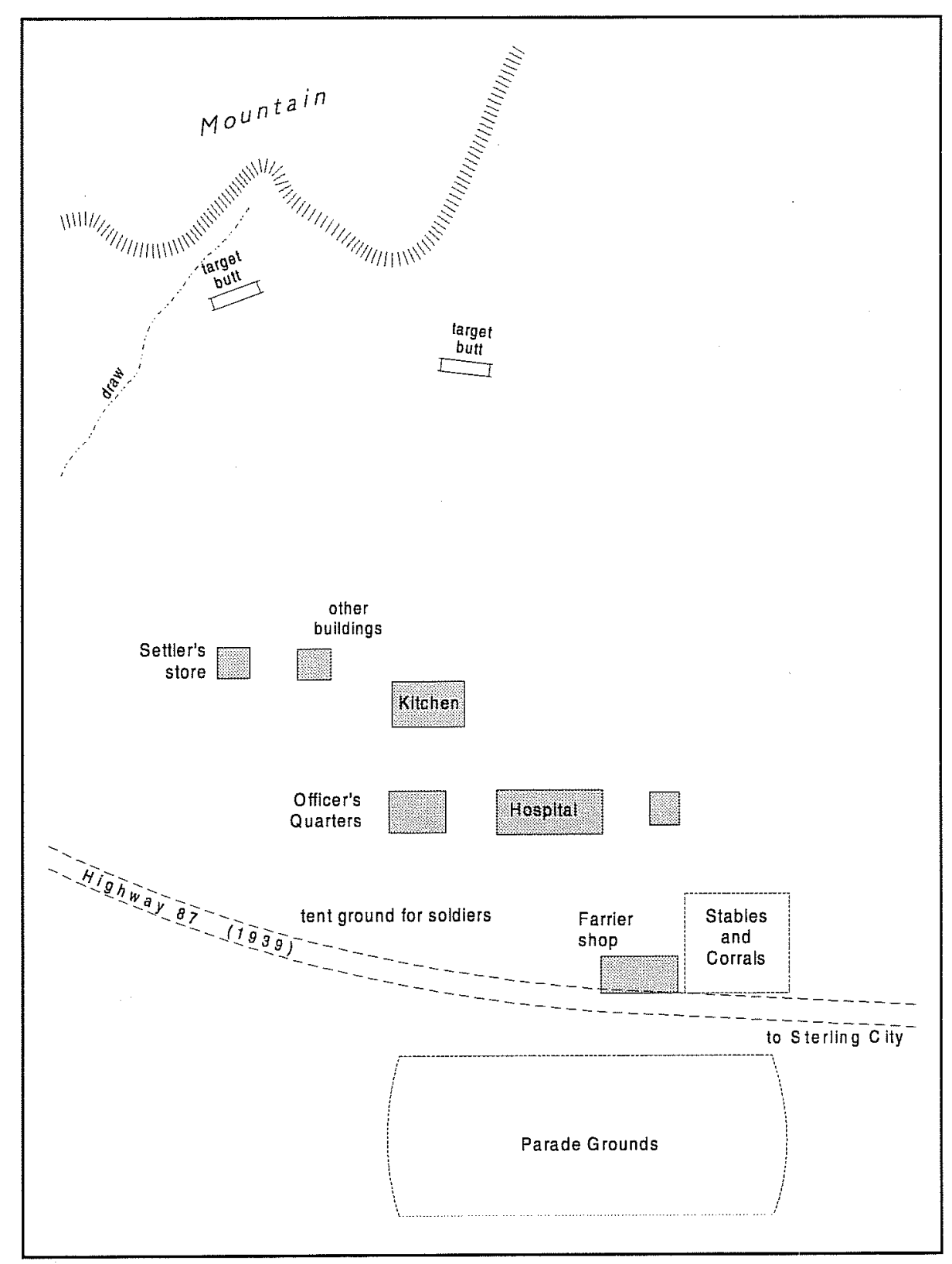

Figure 6-6. Diagram of Camp Elizabeth as remembered by W. F. Kellis. Adapted from Daniels (1976). 
The stone robbers would have scattered the stones of the forge, the size and shape of which would made them attractive to people doing construction elsewhere. Reinforcing this interpretation of the site, excavations at a contemporaneous blacksmith shop affiliated with a trader's house in southwest Oklahoma exhibited the same artifact distribution in relation to a forge (Spivey et al. 1977:184).

\section{Feature 2: Unidentified}

Feature 2 was recorded by TxDOT as a surface scatter of limestone and a subsurface concentration of metal. Excavations within the Feature 2 area yielded a patch of white soil, ca. $5 \mathrm{ft}$ in diameter, and artifacts. From this limited information we were unable to identify this feature. However, it is possible that Feature 2 may be associated with structures located in the tent ground area as suggested in Figure 6-6. The presence of white soil may indicate some kind of lime or plaster residue related to either preparing the earth for a tent or some other temporary structure. John Manguso (personal communication 1998) suggests that instead of wooden floors, structures often had earthen floors consisting of packed gravel and lime and sometimes a layer of hay added for comfort.

\section{Feature 3: Possible Picket Structure Foundation}

Feature 3 was also originally identified by TxDOT staff. The excavations of the bladed area revealed this to be one large feature or two smaller features. These were first identified as anomalies made up of two gravel alignments and several gravel concentrations with artifacts scattered in the 3-5 inch bs level. There are several questions regarding the size, layout, materials used, and function of the feature.

As presented in Chapter 5, the feature is either a ca. 30-x-12.5-ft structure with two rooms, or two smaller structures. If the first scenario is correct, the structure would be similar to a "dog-trot" style building. Haley (1952) suggests that the commander of the post at the Head of the Concho River was ordered to construct a stone building measuring $30 \mathrm{ft}$ long by $10 \mathrm{ft}$ wide. This building, and one like it at Johnson's Station, was to consist of two rooms, "one for the guard of an officer and four men, the other as a stable for their horses" (Haley 1952). Likewise, the Fort Concho Scouting Reports, as mentioned above, reported from Grierson Springs that "a guardhouse was constructed also, built of stone with the roof of thatch, it contains two rooms each twelve feet square in the clear" (FC SR:320-321). The second possibility is that the feature represents not one large building, but the remains of two ca. 12.5-x-12.5-ft buildings or tent foundations. Comparative sources suggest that these gravel alignments with cut nails represent setting trenches for a picket structure (Figure 6-7a). Picket constructions, using the "stockade" method, were extremely expedient buildings and were known to have been used at almost all the forts (Graham 1970:178). Graham (1970:177-178) suggests the following about a picket construction:

The first step in their construction was the digging of a ditch about one to two feet deep in the shape of a rectangle, the size varying according to the function of the structure. Four large supporting posts were then placed at the corners, after which the ditch was lined with posts four to six inches in diameter until the four sides became rigid. Shorter posts were used below windows and omitted altogether at doors. Along the tops of the posts, a sawn piece of lumber was attached by spikes to the ends of the log pickets, forming a plate to receive roof timbers. The cracks between the logs were filled with wood chips and plastered with mud or lime ... These were buildings with roofs of long prairie grass tied in bundles or of tarpaulin, simple boxing crates with sod on them, or portable frames covered with canvas.

It was difficult to tell whether the entire structure was composed of pickets, or just the western wall alignment. Its possible that the feature represents a single solid picket wall with two parallel posts on the opposite side since only patches of gravel were found on this side. A similar building was the canvas-log or canvas-picket cottage which Graham (1970:180-181) suggests was constructed on western Texas posts as a semipermanent shelter for officers and which, more often than not, continued in use throughout the use of the post. The structure was described in a 


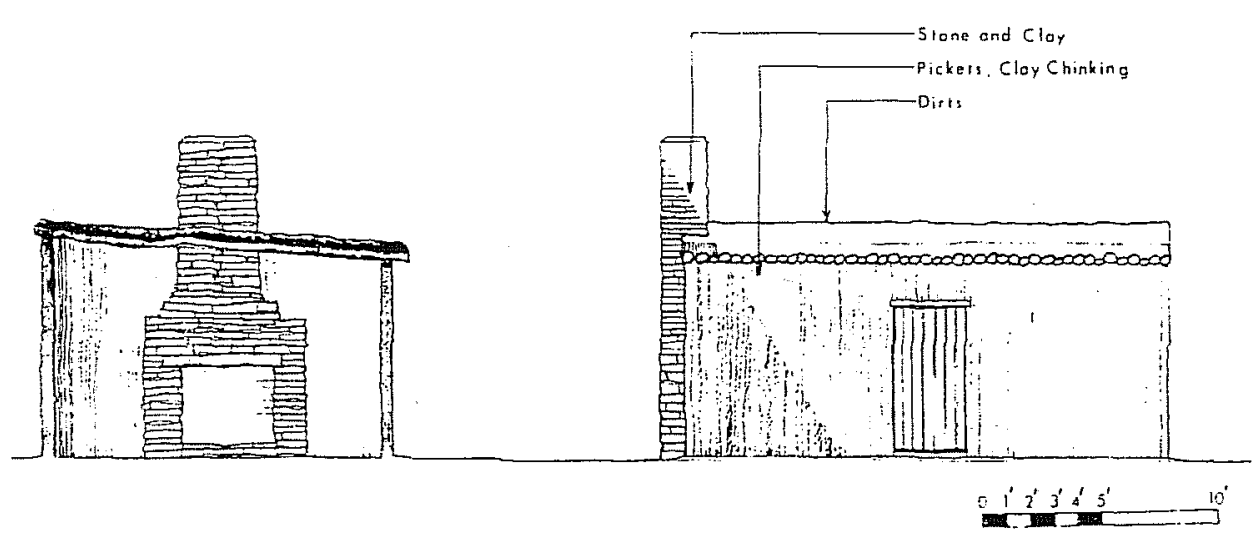

a.
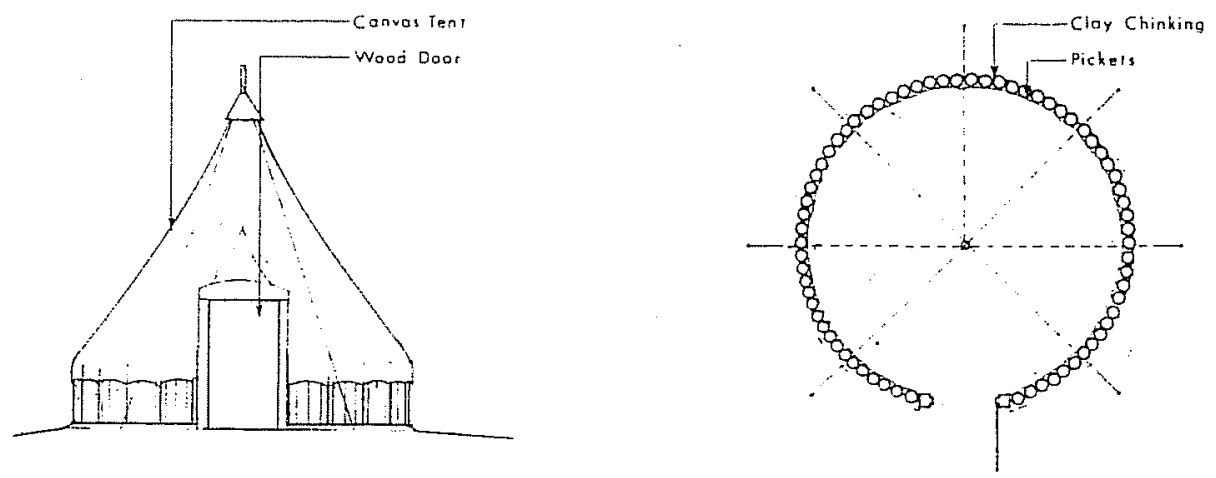

b.

Figure 6-7. Picket structures. Adapted from Graham (1970).

contemporary letter, written from Fort Davis around 1861 , which included a sketch of a rectangular structure with a low picket wall covered with a wall or shelter tent (Graham 1970:180). Another type of canvas-picket combination structure was also employed, composed of a circle of pickets, driven closely together, about two or three feet above the ground, and topped by a conical canvas tent (Graham 1970:181) (Figure 6-7b).

Archaeological investigations in 1981 at Fort Inge, Uvalde County, Texas, recovered a similar feature. The feature, called a "setting trench," was 12 inches wide by 12 inches deep (Nelson 1981:63-65). The fill was a brown clay mixed with a lighter tan caliche and charcoal specks, and no evidence of the wooden posts. In addition, a line of limestone rocks had been placed in the trench to steady the posts, and, outside the corner of one end, clumps of sand and lime mortar were found. Based on this evidence, we believe that Feature 3 was some type of picket construction.

However, another archaeological investigation took place at 41CC131, the presumed site of the camp at the mouth of the Concho River (or Camp at the Head of the Concho) (Earls et al. 1993:73-90). Excavations revealed the remains of a $79-\mathrm{x}-21 \mathrm{ft}$ stone foundation that included an alignment, like that within Feature 3, of "fine- to medium-grained gravels" consistent with the location of the south wall (Earls et al. 1993:80). Earls et al. (1993:80) suggest that the gravels were possibly of either deteriorated mortar or sand foundation. The gravels were slightly lower than the stones, suggesting either ground preparation before the laying of the foundation, remnants of mortar between the stones, or perhaps natural deposition from 
a flooding episode prior to construction (Earls et al. 1993:80).

Whether the function of Feature 3 represents enlisted men's quarters, since Kellis's diagram suggests the location falls within the "tent ground for soldiers" area, or some type of guardhouse, being fairly close to the farrier's shop and stables, is not clear. The artifacts within Feature 3-cut nails, beer bottle fragments, clear drinking glass fragments, and a 4-hole buttonare indicative of some type of living quarters.

\section{Feature 4: Personal Activity Area}

Feature 4 was originally identified by TxDOT during the metal detecting survey. During CAR's, primarily personal artifacts relating to the military were found within the feature (military button, cartridge and bullet, and the cavalry insignia fragment). No structural remains were recovered; therefore we believe the feature possibly represents a personal-military activity area.

Feature 5: Horseshoe And Nail

Feature 5 was identified by TxDOT during a metal detecting survey as a small concentration of metal and one limestone rock on the surface. Further subsurface excavations by CAR revealed the remains of a complete horseshoe and a cut nail which would have given the metal detector a fairly high reading. No structural remains were recovered.

\section{Feature 6: Campfire}

Feature 6 consisted of a 14-ft area of orange soil with grey around the edges and six post holes surrounding it. The post holes were from 2-4 ft apart. Orange coloration represents burned or oxidized soil; therefore, Feature 6 is believed to have been remnants of a campfire in which posts (possibly at different times) would have supported an iron pot, etc., as illustrated in Figure 6-8. Twelve different anomalies contained areas of orange, oxidized soil and probably represent other campfires or burning episodes. Feature 6 was the largest of these areas. This hypothesis seems likely since the plan (Figure 6-6) shows this area to be the tent grounds for soldiers, and thus would have been the most likely places for cooking and preparing meals, or for alleviating the cold west Texas winter chill.

\section{Feature 7: Possible Tent Pad}

Feature 7 consisted of a ca. 9-x-9-ft gravel concentration. Within the bladed areas, this was the largest, roughly square gravel concentration out of the many. This feature is believed to possibly be the remnants of a tent pad, an area where a tent was placed, as suggested by above by John Manguso (personal communication 1998) The ground dimensions are similar to the military specifications for wall tents. Wall tent dimensions measured $9 \mathrm{ft}$ for the length of the ridge and $9 \mathrm{ft}$ in width (Reedstrom 1992:199; Quartermaster General 1986:209). Figure 6-9 shows the several types of military tents used during the nineteenth century, including the wall tent, common tent, and common tent with wall, as adapted from Reedstrom (1992). Other gravel-concentration anomalies, especially A26 and A27 may represent smaller-sized tents. Table 6-1 list several types of tents and their ground (floor) dimensions.

\section{Feature 8: Rock Alignment}

Feature 8 was identified on the surface south of the bladed area during CAR excavations. It is represented by a 20-22 ft limestone rock alignment. Whether this feature is structural or represents rock debris that accumulated against the old right-of-way fence line is unknown. No artifacts were associated with the feature.

Feature 9: Campfire and Possible Picket Structure Location

Feature 9 was comprised of several anomalies, one of which included a very distinct orange oxidized soil area. Adjacent to this was an artifact scatter of window 


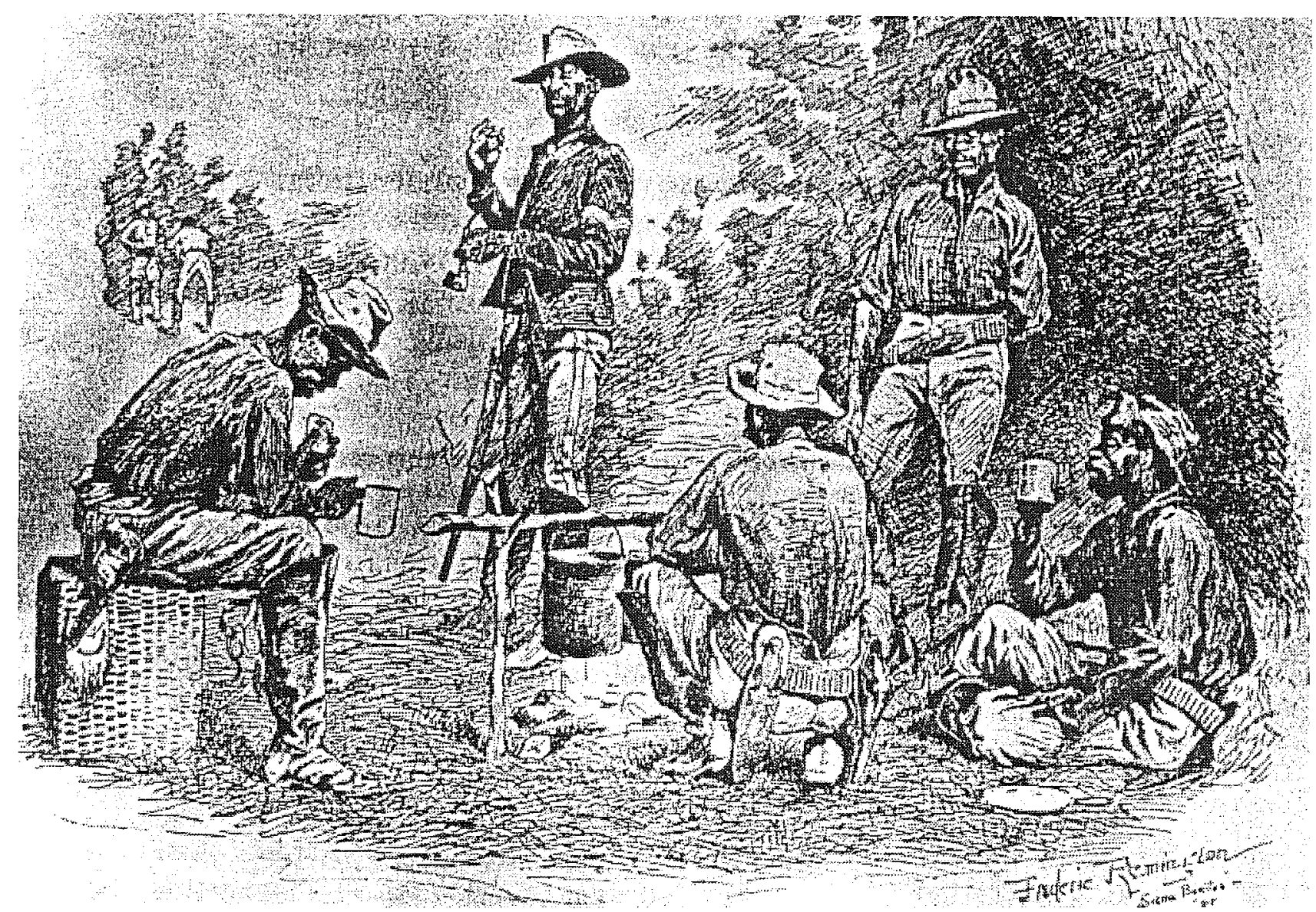

Figure 6-8. Buffalo Soldiers Sitting Around a Carnpfire. Remmington sketch, from Gunnison 1896.

glass, cut nails (two of which were $12 \mathrm{~d}$ nails with grommets), and chert fragments; a post hole depression; and a fairly large area of white soil with mixed gravels, measuring $9 \times 4 \mathrm{ft}$. The $12 \mathrm{~d}$ nails were not large enough to hold securely in the ground, but instead would have gone into wood. The grommets still attached to the nails indicate that the structure was fastened by canvas. Therefore, it is believed that Feature 9 represents an area where there was a pickettype structure with a canvas roof (Figure 6-7). The window glass suggest the structure had at least one window. Likewise, the oxidized soil represents remnants of a possible campfire. The temporary-type structure substantiates that this was indeed the tent/ picket ground area for the soldiers as shown in the surveyor's diagram (Figure 6-6).
Feature 10: Limestone Alignment and Nails

Feature 10 included a small alignment of limestone rock intermixed with cut nails, nail depressions, a metal spike, orange oxidized soil, and burned limestone. This feature may have been some sort of limestone foundation, however, there is no other evidence to identify it definitively .

\section{Feature 11: Limestone Alignment}

Feature 11 is represented by three clusters of limestone, possibly representing some sort of structural stone alignment, measuring $10 \mathrm{ft}$ long and oriented northwest-southeast. A horseshoe nail was located among the rocks. The feature may represent remnants of a building or corral foundation associated with the horse stable area as identified on the plan (Figure 6-6). 


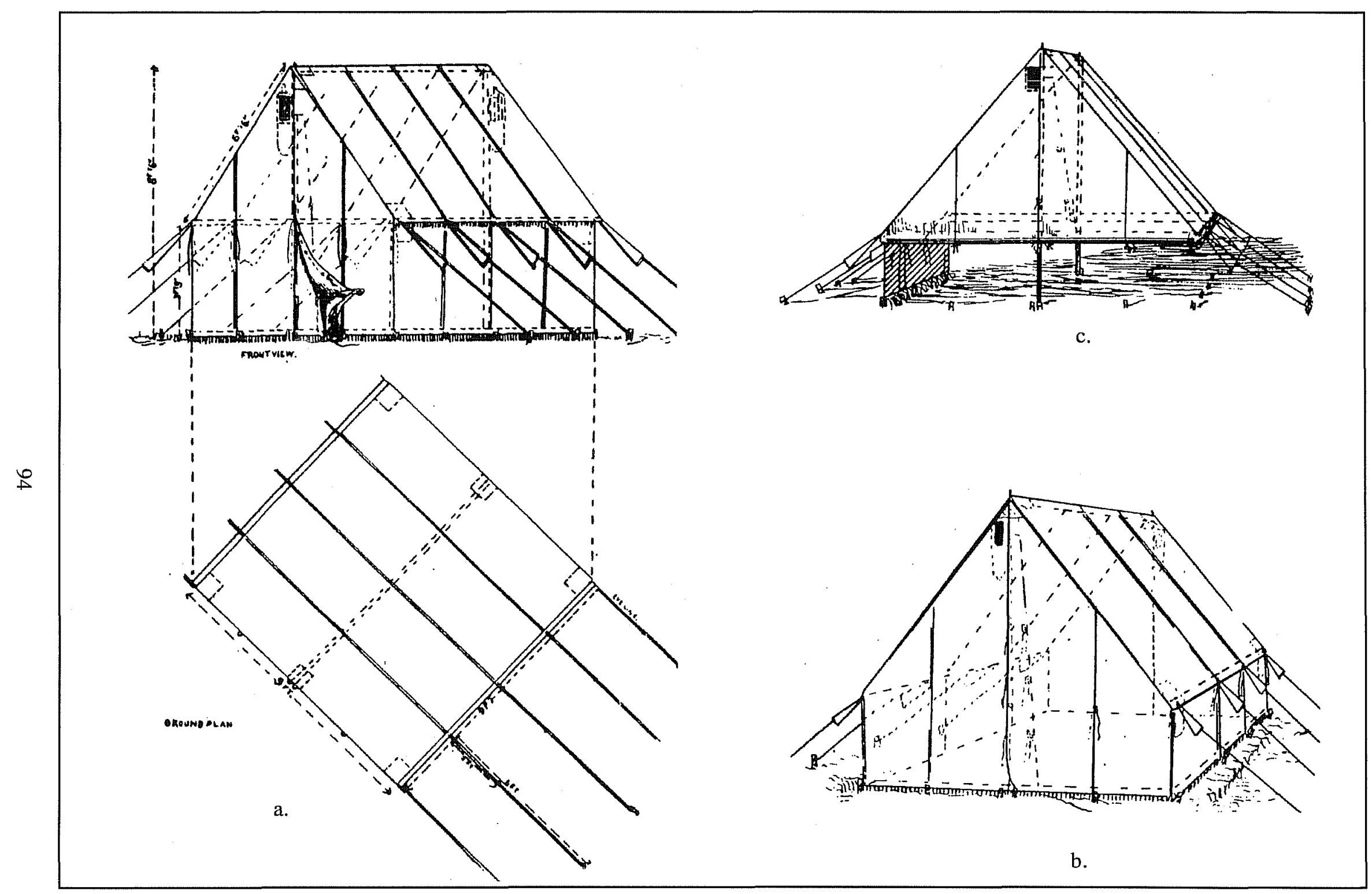

Figure 6-9. Tent structures: $a$. wall tent; $b$. common tent with wall (closed corners); and c. common tent with wall (laced corners). From the Quartermaster General 1986. 
Table 6-1. Specifications for Tents, adapted from

Reedstrom (1992)

\begin{tabular}{|l|l|c|c|}
\hline \multicolumn{1}{|c|}{ Tent Type } & \multicolumn{1}{|c|}{$\begin{array}{c}\text { Shape of } \\
\text { Base }\end{array}$} & $\begin{array}{c}\text { Length of } \\
\text { Ridge } \\
\text { (ft/inch) }\end{array}$ & $\begin{array}{c}\text { Width } \\
\text { (ft/inch) }\end{array}$ \\
\hline Conical & Round & $16^{\prime} 5^{\prime \prime}$ dia. & - \\
\hline $\begin{array}{l}\text { Common tent w/wall } \\
\text { (laced corners) }\end{array}$ & Semi-rectangular & $6^{\prime} 10^{\prime \prime}$ & $8^{\prime} 4^{\prime \prime}$ \\
\hline $\begin{array}{l}\text { Common tent w/wall } \\
\text { (closed corners) }\end{array}$ & Semi-rectangular & $6^{\prime} 10^{\prime \prime}$ & $8^{\prime} 4^{\prime \prime}$ \\
\hline Hospital & Semi-rectangular & $11^{\prime}$ & $1^{\prime}$ \\
\hline Wall & Square & $9^{\prime}$ & $9^{\prime}$ \\
\hline
\end{tabular}

Feature 12: Campfire

Feature 12 consisted of an oval, ca. 1.5-x-1.75-ft, ash, charcoal, and limestone concentration intermixed with metal fragments and a metal button. It represents a well-defined campfire. The diagram (Figure 6-6) identifies this area as the stable or corral area.

Feature 13: Limestone Alignment (Possible Stable Remains)

Feature 13 was an ephemeral stone alignment, measuring ca. $10 \mathrm{ft}$, roughly oriented north-south. The possible alignment may represent what was left of the stables, as identified on the plan (Figure 6-6). The alignment is ca. $35-40 \mathrm{ft}$ east of Feature 1, the possible farrier/blacksmith shop. According to the diagram, this is the approximate location of the east wall of the stables. However, this is only speculative.

\section{Adjacent Area Features}

Feature 14: Possible Outbuilding/Sutler's Store

Surface Feature 14 included the remains of four limestone foundation walls, $1.5 \mathrm{ft}$ thick, of a structure that measured ca. $15 \times 15 \mathrm{ft}$. The surveyor's plan identifies a similar feature as being either the "other outbuildings" or "settler's store" (sutler's store).
Feature 15: Possible Officer's Quarters

Surface Feature 15 consisted of a large mound of limestone rock with visible wall foundations. Based on the visible foundations, the building would have measured ca. 30 x $30 \mathrm{ft}$, had a 2 -ft thick walls, and contained four rooms. In comparison, the 1889 plan of Fort Concho contains several officer's quarters that had four rooms in the main portion of the buildings (Bell et al. 1980:46-47). The room dimensions were $15 \times 17 \mathrm{ft}$ and $18 \times 14 \mathrm{ft}$. Based on these dimensions, the main buildings for these Fort Concho officers' quarters would have been ca. $30 \times 32 \mathrm{ft}$ and $36 \times 15 \mathrm{ft}$. These dimensions and the fact that they had four divided rooms compare favorably with Feature 15. Therefore, we agree with the plan (Figure 6-6) that identifies this building as an officers' quarters.

Feature 16: Limestone Concentration

Surface Feature 16 was a ca. 25 -ft-diameter limestone mound. No foundations were visible. This feature is in the area identified as the kitchen in the diagram (Figure 6-6).

\section{Feature 17: Artifact Concentration}

Surface Feature 17 was comprised of a ca. $17-\mathrm{ft}-$ diameter artifact concentration located 8-10 ft southeast of Feature 16. The artifacts included bottle glass and undecorated whiteware sherds. The plan does not identify a structure in this area; however, the domestic related artifacts located in the vicinity of 
Feature 16 provide evidence for it functioning as a kitchen.

\section{Feature 18: Possible Hospital}

Surface Feature 18 was a large mound of limestone rocks with wall foundations visible on the surface. The feature measured ca. $30 \times 25 \mathrm{ft}$, with a 2 -ft thick wall. This feature is identified in Figure 6-6 as a hospital. Feature 18 is believed to have been the remains of a hospital because numerous aqua medicine bottle sherds were found around the exterior of the south wall. Specifications for hospitals at forts are normally much larger than this feature; however, this was a temporary subpost, and the hospital may have been a one room ward. Figure 6-10 is an illustration of the restored hospital at Fort Concho. The 1860 specifications for hospitals speaks of "wards 25 feet long" (RBQA 1860:3); therefore, Feature 18 would have met at least the minimum requirements for a oneroom ward hospital.

\section{Feature 19: Possible Cistern Remains}

Surface Feature 19 was a scatter of limestone rock with several rocks forming a ca. 9-ft-diameter circular pattern, with a depression in its center. This feature is not identified on the plan, but possibly represent the remains of a cistern. The Fort Griffin plan shows a cistern attached to the back of the hospital (Fox 1976:3).

\section{Summary}

The archaeological investigations have provided a substantial amount of physical information about the function and activities of the military at Camp Elizabeth. The interpretations presented here suggest that the remains of several buildings within the major areas of the site were identified according to their postulated function.

\section{Site Settlement and Layout}

\section{Maureen Brown and José E. Zapata}

At most of the established frontier posts, a temporary camp was necessary during construction of the permanent structures. Camp structures were made of canvas and pickets until better, more permanent,

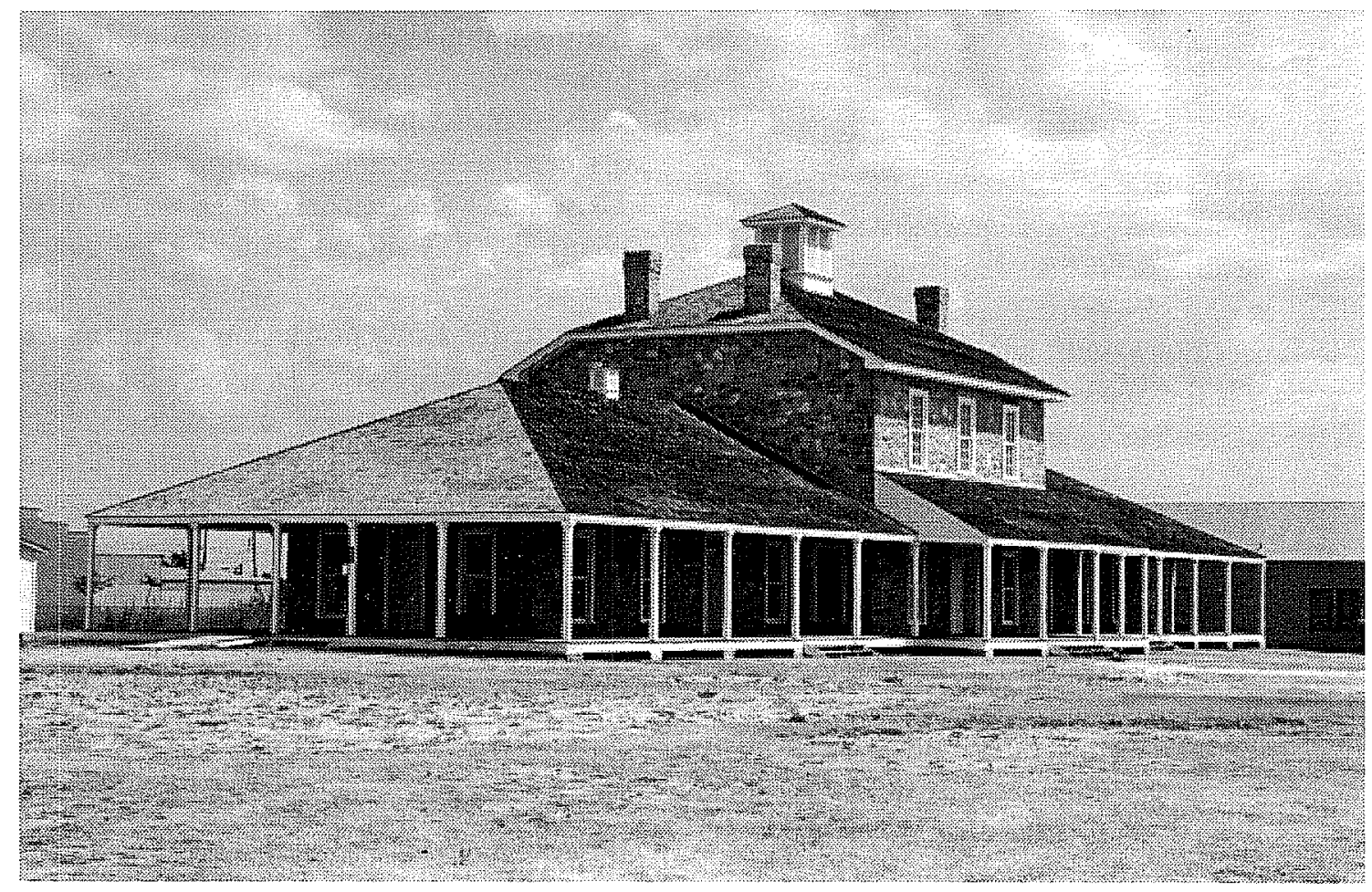

Figure 6-10. Fort Concho hospital as it looks today. 
structures were constructed. This was the case for Fort Concho, when it was first established as Camp Hatch (Bell et al. 1980:14). Graham (1970:170-171) states, "perhaps the greatest determining factor of all in the architecture of the frontier forts was 'field experience,'. . . Government draftsmen had created standardization of plans and designs, but it was the ability of the army carpenters and masons to use indigenous materials that were available on the frontier...most buildings still conformed to the plans and specifications of various army agencies while differing with materials." Detailed specifications for the standardized plan of a garrison, positions of buildings, dimensions of buildings, and materials suggested can be found in Regulations concerning Barracks and Quarters for the Army of the United States, 1860. In general, the plan required "officer's quarters, chaplain's quarters, and officers' mess on one line, facing a parade ground open at both ends and varying in breadth at different posts, according to the ground and other circumstances, from 250 to 400 feet; all other buildings on the other side from the officers' line ..." (RBQA 1860:7) (Figure 6-11).

However, besides the standardization, the function, terrain, and personalities affected the construction and design of a fort. Military physicians were concerned about the buildings and materials affecting the health of the soldiers (Graham 1970; Robinson 1986). Likewise, as mentioned above, the commanding officer made the final decisions about how best to build the post (Graham 1970:172).

Graham (1970:173) suggests, without exception, "Texas forts were not blockhouses or in any way strongly fortified places for siege warfare. They were cantonments-places for the soldiers to clean up their kits after spending three or four weeks on a scout, to rest their horses, and to be with their families... because the troops were almost entirely cavalry and required horse-scale parade grounds, there were ample open spaces in the fort complexes."

A standard layout for the Texas forts included the officer's quarters and enlisted men's barracks flanking opposites sides of a parade ground. Service buildings, including stables, were situated in the vicinity of the barracks, all of which were downwind from the officer's housing (Robinson 1986). The post hospital occupied a commanding position at one end of the parade ground. The 1875 plan of Fort Concho (Figure 6-12) compares with the standardized plan. The officer's quarters were located to the south of the central parade ground quadrangle, and the enlisted men's barracks were on the north. Behind the enlisted men were the quarters for the married enlisted men. The stables were located behind the barracks. The blacksmith shop was located to the northeast of the stables (northwest corner area of the fort). At the eastern end of the parade ground were the storehouses and administrative offices. The post hospital was prominently isolated in the southeast corner of the parade ground.

The Fort Concho buildings consisted of "quarters for eight companies; officers' quarters, nine buildings; hospital, twenty-four beds; guardhouse; storehouses, two; corrals, seven with stables inside; magazine, workshops, etc. All the buildings are of stone and well built" (Headquarters Military Division of the Missouri 1876 [1972]:189).

The architectural layout for Fort Concho's subpost Camp Elizabeth did not conform to the standard military plan for Texas frontier posts (Figure 6-13). However, Camp Elizabeth was a temporary subpost. The remaining stone foundations are evidence of what semi-permanent structures once existed at the camp. The more prominent stone structures in the northern section of the camp included a post hospital with possible cistern, officer's quarters with four rooms, and an outbuilding/sutler's store. From what remains in the archaeological record, the only other semipermanent building would have been the blacksmith/farrier's shop, which was located in the southeastern portion of the camp. Most of the structures would have been temporary picket of canvas-type structures or tents. Evidence for these was found in the proposed soldier tent ground area, at least the portion that was tested within the project right-ofway. In the northern section, temporary structures may have included a kitchen in the back of these quarters, and undoubtedly a latrine.

According to the surveyor's map (Figure 6-6), the parade ground was located in the southern portion of 


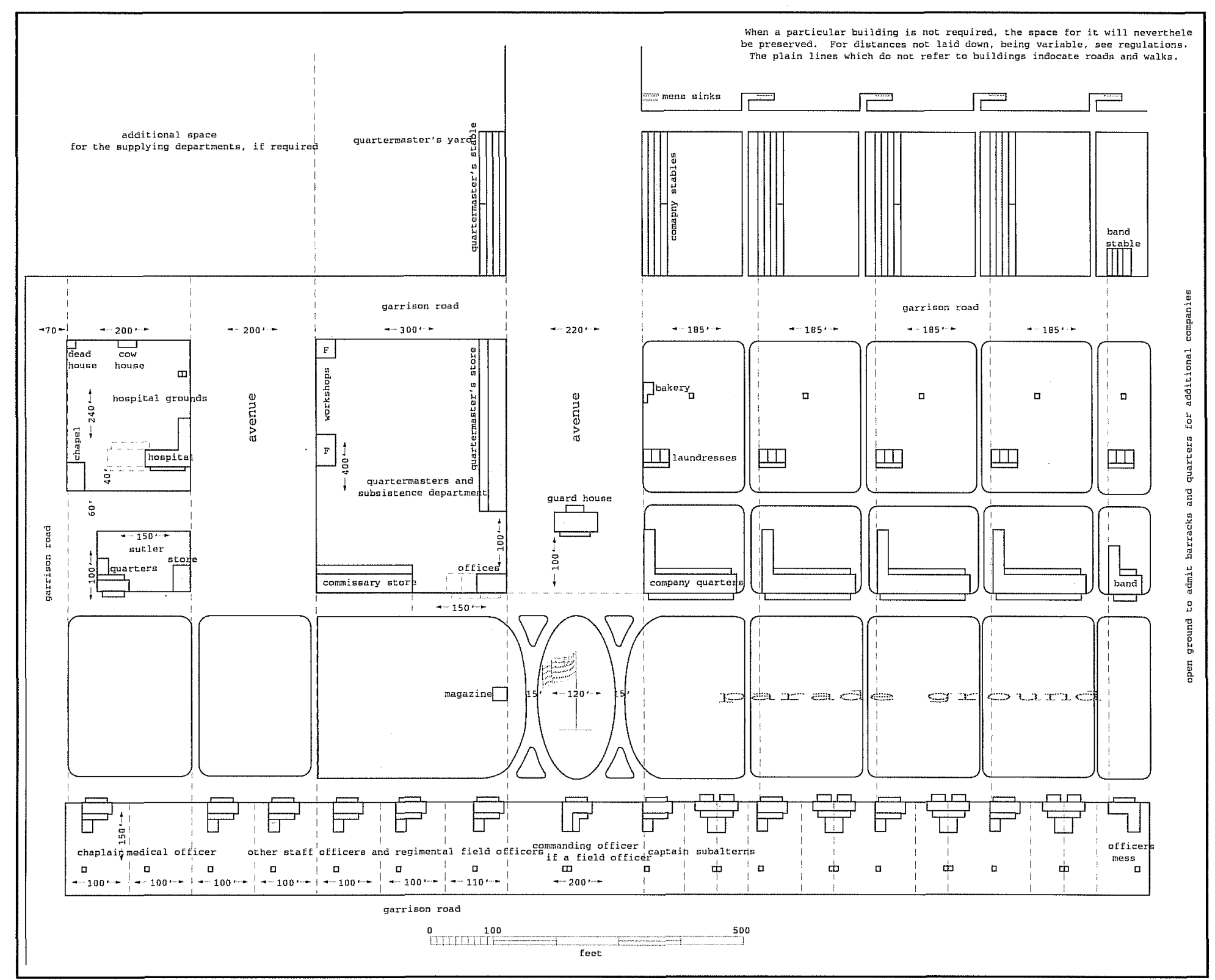

Figure 6-11. Standard plan of a Garrison. Adapted from (Regulations concerning Barracks and Quarters for the Army of the United States, 1860, Plate XVI). 


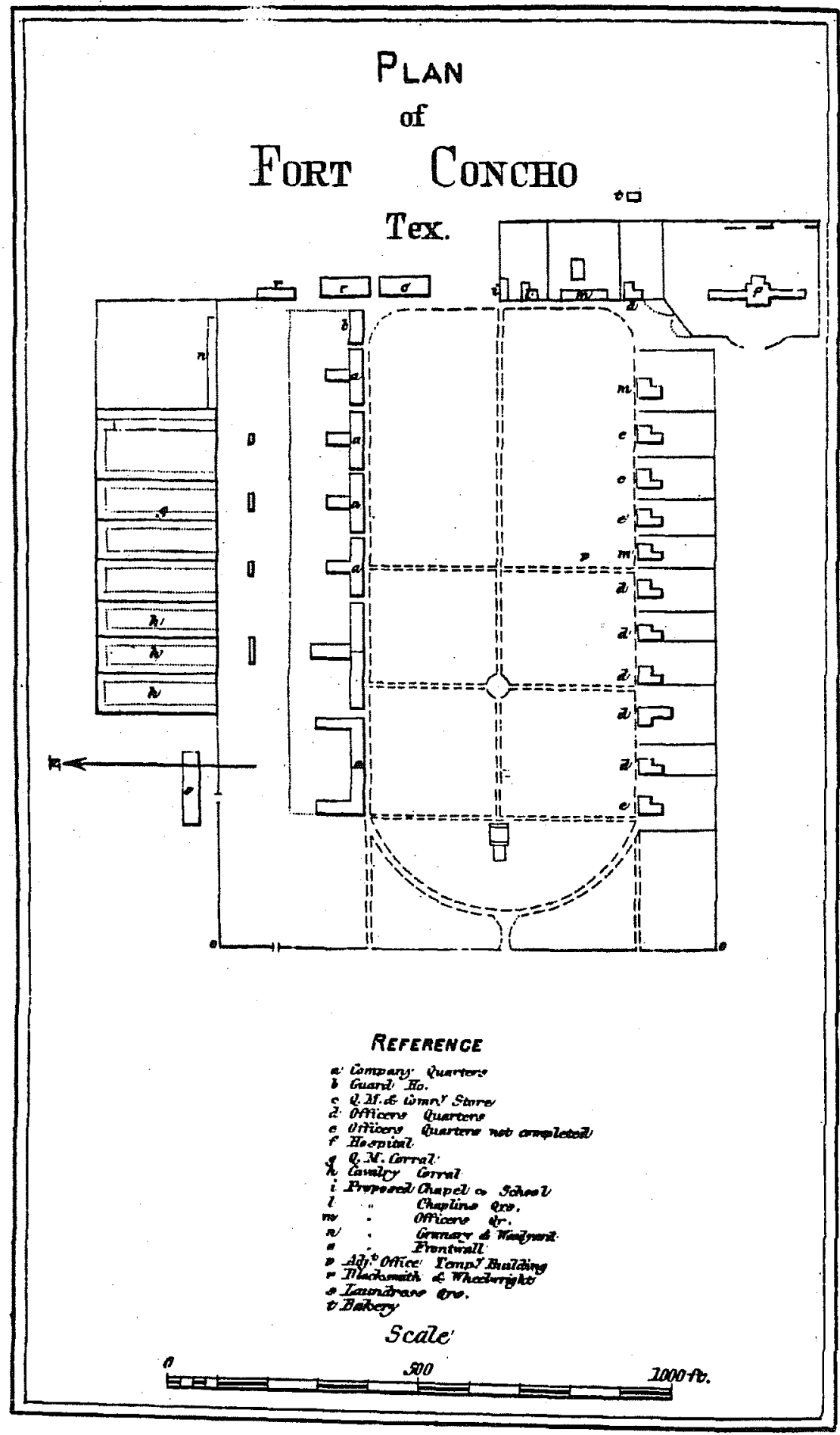

Figure 6-12. Plan of Fort Concho in 1875. From Headquarters Military Division of the Missouri 1876:188.

the camp and was oriented east-west. Instead of the standard plan where the enlisted men's tents are positioned on the opposite side of the parade ground, they were in the middle, and adjacent to the officer's quarters and other northern structures. Much of the middle and northern boundaries of the remaining tent ground area were outside the project area and would not have been visible on the surface. One possible explanation for the parade ground being situated to the south of the tent ground area comes from a report by the commanding officer of Company M, 10th Cavalry. In October 1880, Captain Norvell reports, "A strong objection to occupy the Camp at the head of the North Concho River another year, is its proximity to the towns about Fort Concho. It was with difficulty that I carried out the orders of the District commander in relation to traders and other Camp followers . . . Every pay day the Camp was besieged by traders and gamblers, and as they could get shelter at any point on the river" (FC SR:329-332). If "traders and gamblers" were setting up temporary shelters along the river, the commanding officer may have wanted an open space (i.e., parade ground) between the encampment of the enlisted men and the transient "traders."

In comparing the positioning of the buildings with other sites, the campsite is interesting in one aspect: the stables, workshops, and possibly the corral area faced the prevailing southeasterly winds. The tent ground area was directly downwind of this area and the officer's quarters were downwind of these structures. In our research we found only Fort Duncan to have a blacksmith shop located in the southeastern area of the fort. In addition, Fort McIntosh also has stables and workshops in the southern portion of its post (Headquarters Military Division of the Missouri 1876, 1972:202). 


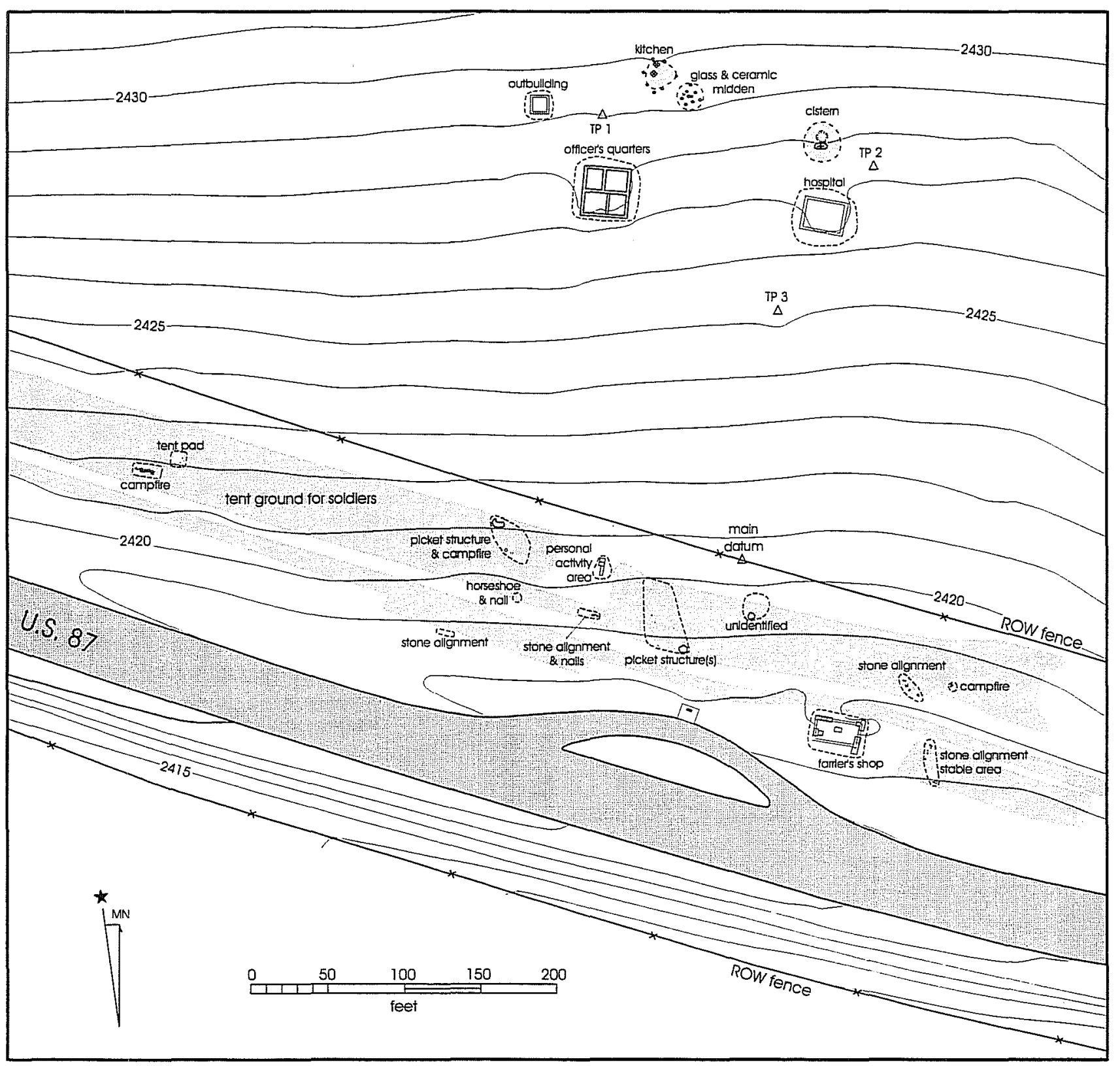

Figure 6-13. Plan of Camp Elizabeth in 1997.

\section{Site Selection and Utilization of Resources}

\section{Maureen Brown}

The military would have utilized the available natural resources in the area for some of the same reasons earlier Native Americans were attracted to the region. In general, military sites were judiciously chosen, usually situated on hills, well drained, and in close proximity to water (Graham 1970:170). Camp
Elizabeth was no exception. The North Concho River and the nearby springs provided fresh drinking water for the men and their horses. The river valley forms a natural route from the High Plains to more southern areas. The location near the water also served as a strategic military position from which to observe indigenous groups and travelers who were attracted by this permanent source of water. In addition, the land surface in the area of the camp gently slopes upward from the river bank to the limestone hills (McIntyre Butte) that dominate the horizon to the northeast (Kenmotsu et al. 1997:3). From the main 
part of the camp and McIntyre Butte the soldiers would have had a good view of the river below.

Raw materials necessary for constructing the subpost were readily available in the immediate area. McIntyre Butte paralleling the northern extent of the camp provided an abundant source of limestone rock for the camps more permanent structures. These included the farrier's shop, hospital, and officer's quarters, as confirmed during the archaeological investigations.

The region's vegetation was utilized by the military and earlier peoples. During the camp's military occupation, the available mesquite, juniper, and other trees were used in the construction of less permanent structures, such as picket buildings. Wood was also used as roofing material and as posts for raised campfire structures. Possible postholes and oxidized soil features were identified during the archacological investigations, confirming the existence of these structures and campfires. The military also used wood as a fuel source for cooking and heating. Sources also suggest the variety of grasses in the region were used for hay to feed the military's livestock and horses.

During the late-nineteenth century the camp occupants would have had military issued canned food items, as well as cattle. However, the soldiers also probably supplemented their diet by hunting wild game in the region. There were numerous deer, antelopes, rabbits, squirrels, and various types of birds around Camp Elizabeth at that time. In addition, the North Concho River provided various types of fish, turtles, and an abundance of mussels, as its name implies. The faunal sample identified during the archaeological investigations confirmed the presence of black-tailed jack rabbit, turkey, and turtle. A few mussel shell fragments were recovered from four units (U60, U70, $\mathrm{U} 75$, and U79) and from two anomalies (A34 and A42).

\section{Summary}

Maureen Brown

The Camp at the Head of the North Concho or "Camp Elizabeth" played a minor role in the development of the western frontier of nineteenth-century North America, but it played a pivotal role in the development of black Americans, known as Buffalo Soldiers, in the U.S. military. The archival evidence indicates that Camp Elizabeth was intermittently used at least as early as 1879 . Construction probably occurred in 1880 and the camp was abandoned by the military in 1882. Records show that various companies of the 10th Calvary, primarily Buffalo Soldiers, were stationed at Camp Elizabeth. No evidence, archival or archaeological, was found to support the reported use of the area by Texas Rangers.

We were unable to locate post or subpost layouts similar to that of Camp Elizabeth. Although the camp plan was not a typical military layout, it met the basic military criteria for being situated near reliable water and it had a good vantage point by being at the base of one of the most prominent hills in the area. The North Concho River is to the south of the camp, and the McIntyre Butte is to the north. Strategically, it is also located within one of the narrowest gaps of land along the North Concho River, which would have positioned it in a prime location for monitoring incoming traffic from the northwest.

This excavation represents one of only a very few conducted at subposts in the American frontier. Although the sources of information differ between archaeological and archival data, each provides a view of the design and construction of outpost camps in the late-nineteenth-century U.S. military. The investigations of Camp Elizabeth indicate that the camp met the basic layout criteria although it did not follow a standard military plan. The artifacts confirmed the military presence and provided useful hints of the activities that occurred at the subpost.

\section{Epilogue}

In October 1997, the site was revisited to complete the mapping. An oil drilling rig, oil pipeline, and an associated road had been built along the northern boundaries of Camp Elizabeth in the adjacent property. This construction destroyed surface Features 14, 17, and 19. 


\section{References Cited}

Adams, R. M.

1966 The Evolution of Urban Society: Mesopotamia and Prehispanic Mexico. Aldine, Chicago.

Ascher, R., and C. Fairbanks

1971 Excavation of a Slave Cabin: Georgia, U.S.A. Historical Archaeology V:3-17.

Assad, C., and D. R. Potter

1979 An Intensive Archaeological Survey of Enchanted Rock State Natural Area, Llano and Gillespie Counties, Texas. Archaeological Survey Report, No. 84. Center for Archaeological Research, The University of Texas at San Antonio.

Baker, V. G.

1978 Historical Archaeology at Black Lucy's Garden, Andover, Massachusetts: Ceramics from the Site of a Nineteenth Century African-American. Papers of the Robert S. Peabody Foundation for Archaeology, Vol. 8. Phillips Academy, Andover.

1980 Archaeological Visibility of African-American Culture: An Example from Black Lucy's Garden, Andover, Massachusetts. In Archaeological Perspectives on Ethnicity in America, edited by $\quad$ R. L. Schuyler, pp. 29-37. Baywood, Farmingdale, New York.

Bammforth, D. B.

1988 Ecology and Human Organizations on the Great Plains. Plenum, New York.

Bell, Klein and Hoffman

1980 Fort Concho National Historic Landmark, San Angelo, Texas: A Master Plan for Development. Bell, Klein, and Hoffman, Architects and Restoration Consultants, Inc., Austin.

Black, S. L.

1989 Central Texas Plateau Prairie. In From the Gulf to the Rio Grande: Human Adaptation in Central, South, and Lower Pecos Texas, by T. R. Hester, S. L. Black, D. G. Steele, B. W. Olive, A. A. Fox, K. J. Reinhard, and L. C. Bement, pp. 17-38. Research Series, No. 33. Arkansas Archeological Survey, Fayetteville.

Blum, E. L.

1977 Soil Survey of Sterling County, Texas. Soil Conservation Service, Department of Agriculture, Washington, D.C.

Botts, O. C., B. Hailey, and W. D. Mitchell

1974 Soil Survey of Coleman County, Texas. Soil Conservation Service, Department of Agriculture, Washington, DC.

Bousman, C. B., A. A. Fox, K. J. Gross, and I. W. Cox

1995 Historical Archaeology in Downtown San Antonio Texas: An Evaluation of Properties at the Proposed VIA Downtown Park and Ride Facility. Archaeological Survey Report, No. 240. Center for Archaeological Research, The University of Texas at San Antonio. 
Brinkerhoff, S. B.

1976 Metal Uniform Insignia of the Frontier U.S. Army, 1846-1902. Museum Monograph No 3, Arizona Historical Society.

Carroll, J. M., editor

1971 The Black Military Experience in the American West. Liveright, New York.

Carskadden, J. and Gartley, R.

1990 A Preliminary Seriation of 19th Century Decorated Porcelain Marbles. Historical Archaeology 24(2): 55-69.

Carter, R. G.

1961 [1935] On the Border with MacKenzie or Winning West Texas from the Comanches. Antiquarian Press, New York.

Cashin, H. V.

1993 Under Fire: With the Tenth U.S. Cavalry. University Press of Colorado, Niwot, Colorado.

Cheek, C. D.

1977 The Fort Concho Trash Dump: An Archaeological Analysis. Archaeological Research Associates, Research Report No. 12, Tulsa, OK.

Cheek, C. D., and A. Friedlander

1990 Pottery and Pig's Feet: Space, Ethnicity, and Neighborhood in Washington, D.C. Historical Archaeology 24(1):34-60.

Cheek, C. D., A Friedlander, C. A. Holt, C. H. Lee Decker, and T. E. Ossin

1983 Archaeological Investigations at the National Photographic Interpretation Center Addition, Navy Yard Annex. Soil Systems, Alexandria, Virginia.

Chipman, D. E.

1992 Spanish Texas, 1519-1821. The University of Texas, Austin.

Collins, M. B.

1995 Forty Years of Archeology in Texas. Bulletin of the Texas Archeological Society 66:361-400.

Creel, D.

1986 Addressing the Importance of Acorns in Archaic Subsistence: the Distribution of Prehistoric Burned Rock Middens in West Central Texas. Ph.D. dissertation, Department of Anthropology, The University of Arizona.

1990 Excavations at 41TG91 Tom Green County, Texas 1978. Publications in Archaeology, Report No. 38. State Department of Highways and Public Transportation, Highway Design Division, Austin.

Crimmins, M. L.

1934 General Mackenzie and Fort Concho, West Texas Historical Association Year Book X:16-31.

Daniels, B.

1976 Milling Around Sterling County: A History of Sterling County. Staked Plains, Canyon, Texas. 
Dearen, $\mathrm{P}$.

1993 Portraits of the Pecos Frontier. Texas Tech University Press, Lubbock.

Deetz, J. F.

1977 In Small Things Forgotten. Anchor, New York.

Dillehay, T.

1974 Late Quaternary Bison Population Change on the Southern Plains. Plains Anthropologists 19(64):180 196.

Dobie, J. F.

1989 [1929] A Vaquero of the Brush Country. University of Texas Press, Austin.

Drucker, L. M.

1981 Socioeconomic Patterning at an Undocumented Late Eighteenth Century Lowcountry Site: Spiers Landing, South Carolina. Historical Archaeology 15(2):58-68.

Earls, A. C., P. L. O’Neill, D. Williams, C. Lintz, W. N. Trierweiler, J. M. Quigg, G. Hamblett, A. C. Treece, and D. Scurlock

1993 Cultural Resource Investigations in the O. H. Ivie Reservoir, Concho, Coleman, and Runnels Counties, Texas. Volume V: Historical Resources. Mariah Associates, Inc. Technical Report No. 346-V, Austin.

Fehrenbach, T. R.

1968 Lone Star: A History of Texas and Texans. Macmillan, New York.

1974 Comanches: The Destruction of a People. Alfred A. Knopf., New York.

Felton, D. L., and P. D. Schulz

1983 The Diaz Collection: Material Culture and Social Change in Mid-Nineteenth Century Monterey. California Archaeological Report 23. California Department of Parks and Recreation, Sacramento.

Fenneman, N.

1931 Physiography of the Western United States. McGraw-Hill, New York.

Foner, J. D.

1974 Blacks and the Military in American History: A New Perspective. Praeger, New York.

Ford, John S.

1987 [1963] Rip Ford's Texas. University of Texas Press, Austin.

Fowler, A. L.

1971 The Black Infantry in the West, 1869-1891. A Negro Universities Press Publication, Greenwood Publishing Corp., Westport, Connecticut.

Fox, A. A.

1976 Archaeological Investigations at Fort Griffin State Historical Park, Shackelford County, Texas. Center for Archaeological Research. The University of Texas at San Antonio. Archaeological Survey Report, No. 23. 
Fox, D. E.

1983 Traces of Texas History: Archaeological Evidence of the Past 450 Years. Corona, San Antonio.

Fried, $M$.

1967 The Evolution of Political Society. Random House, New York.

Gould, C. N.

1906 The Geology and Water Resources of the Eastern Portion of the Panhandle of Texas. U.S. Geological Survey Water Supply Paper 154. United States Government Printing Office, Washington, DC.

Gould, F. W.

1975 Common Texas Grasses: an Illustrated Guide. Texas A\&M University, College Station.

Graham, E.

1970 Federal Fort Architecture in Texas during the Nineteenth Century. Southwestern Historical Quarterly.

Gunnison, A.

1896 Wayside and Fireside Rambles: Sketches, Reminiscences, and Confessions. Universalist Publishing House, Boston.

Haley, J. E.

1952 Fort Concho and the Texas Frontier. San Angelo Standard-Times, San Angelo, Texas

Harris, E. S.

1985 An Archaeological Study of the Timmeron Rockshelter (41HY95), Hays County, South Central Texas. Special Publication 4. Southern Texas Archaeological Association, San Antonio.

Headquarters Military Division of the Missouri

1876 [1972] Outline Descriptions of the Posts in the Military Division of the Missouri, Commanded by Lieutenant General P. H. Sheridan, Accompanied by Tabular Lists of Indian Superintendencies, Agencies and Reservations, and a Summary of Certain Indian Treaties. Headquarters Military Division of the Missouri, Chicago.

Henry, S. L.

1987 Factors Influencing Consumer Behavior in Turn of the Century Phoenix, Arizona. in Consumer Choice in Historical Archaeology, edited by S.M. Spencer-Wood, pp. 359-381. Plenum, New York.

Henry, S. L., and P. H. Garrow

1982 The Historic Component, Part II. In The City of Phoenix: Archaeology of the Original Phoenix Townsite, Blocks 1 and 2, edited by J. S. Cable, S. L. Henry, and D. E. Doyel. Publications in Archaeology 1. Soil Systems, Phoenix.

Henry, S. L., K. S. Hoffman, F. Ritz, and J. A. McKenna

1983 The Archaeology of an Early 20th-Century Residential Neighborhood in the Murphy Addition. Soil Systems, Phoenix. 
Hester, T. R.

1970 Burned Rock Midden Sites on the Southwestern Edge of the Edwards Plateau, Texas. Plains Anthropologists 15:237-248.

1989 Historic Native American Populations. In From the Gulf Coast to the Rio Grande: Human Adaptation in Central, South and Lower Pecos Texas, by T. R. Hester, S. L. Black, D. G. Steele, B. W. Olive, A. A. Fox, K. J. Reinhard, and L. C. Bement, pp. 78-84. Research Series No. 33. Arkansas Archeological Survey, Fayetteville.

Hester, T. R. (editor)

1991 The Burned Rock Middens of Texas: An Archeological Symposium. Studies in Archeology 13, Texas Archeological Research Laboratory, The University of Texas at Austin.

Hester, T. R., S. L. Black, D. G. Steele, B. W. Olive, A. A. Fox, K. J. Reinhard, and L. C. Bement

1989 From the Gulf to the Rio Grande: Human Adaptation in Central, South, and Lower Pecos Texas. Arkansas Archaeological Survey Research Series No. 33. Fayetteville, Arkansas.

Hodder I., and C. Orton

1979 Spatial Analysis in Archaeology. Cambridge University Press, Cambridge, England.

Huebner, J. A.

1991 Late Prehistoric Bison Populations in Central and South Texas. Plains Anthropologists 36(137):343358.

Johnson, L., Jr.

1994 The Life and Times of Toyah-Culture Folk as Seen From the Buckhollow Encampment, Site 41 KM16 of Kimble County, Texas. Office of the State Archeologist Report 38. Department of Transportation and the Texas Historical Commission, Austin.

Johnson, L., Jr., and G. T. Goode

1994 A New Try at Dating and Characterizing Holocene Climates, as well as Archeological Periods, on the Eastern Edwards Plateau. Bulletin of the Texas Archeological Association 65:1-51.

Kelso, W. M.

1984 Kingsmill Plantation, 1619-1800: Archaeology of Country Life in Colonial Virginia. Academic, New York.

Kenmotsu, N. A., J. W. Clark, Jr., and D. Crawford

1997 Archeological Assessment of Historic and Prehistoric Sites Along U.S. 87, Sterling, County, Texas. Archeology Studies Program, Cultural Resource Management Section, Environmental Affairs Division, Texas Department of Transportation, Austin.

Kilgore, D.

1973 A Ranger Legacy: 150 Years of Service to Texas. Madrona, Austin.

Klein, T. T., and P. H. Garrow (editors)

1982 Final Archaeological Excavations at the Wilmington Boulevard, Monroe Street to King Street, Wilmington, New Castle County, Delaware. Archaeological Series, Number 29, Delaware Department of Transportation, Dover. 
Largent, F.B. Jr.

1996 Cultural Resources Survey of 5,625 Acres within the Fort Sill Military Reservation, Fort Sill, Oklahoma. Fort Sill Military Reservation. Technical Series Report of Investigations, Number 3. Geo-Marine, Plano, Texas.

Leckie, W. H.

1967 The Buffalo Soldiers: A Narrative of the Negro Cavalry in the West. University of Oklahoma Press, Norman.

Lincecum, J. B. and E. H. Phillips, 1994 Adventures of a Frontier Naturalist; the Life and Times of Dr. Gideon Lincecum. Texas A\&M University, College Station.

Logan, H. C.

1959 Cartridges: A Pictorial Digest of Small Arms Ammunition. Bonanza Books, New York.

Loomis, N. and A. Nasatir,

1967 Pedro Vial and the Roads to Santa Fe. University of Oklahoma, Norman.

Majewski, T., and M. J. O'Brien

1987 The Use and Misuse of Nineteenth Century English and American Ceramics in Archaeological Analysis. In Advances in Archaeological Method and Theory, Vol. 11, edited by M. B. Schiffer, pp. 97-209. Academic, Orlando.

Marcy, R. B.

1850 Report of Captain R. B. Marcy's Route from Fort Smith to Santa Fe. Reports of the Secretary of War. 31st Congress, 1st Session, Senate Executive Document Number 64, pp. 171-227. Washington, D. C.

McKinney, W.

1981 Early Holocene Adaptation in Central and Southern Texas: The Problem of the Paleo-Indian-Archaic Transistion. Bulletin of the Texas Archeological Association 52:91-120.

Meltzer, D. J., and M. R. Bever

1995 Paleoindians of Texas: An Update on the Texas Clovis Fluted Point Survey. Bulletin of the Texas Archeological Society 66:47-81.

Miller, G. L.

1979 Pettus and Utopia: A Comparison of Faunal Remains from Two Late Seventeenth Century Virginia Households. In Conference on Historic Sites Archaeology 1978 13:158-179.

Nelson, G.

1981 Preliminary Archaeological Survey and Testing at Fort Inge, Texas. Uvalde County Historical Commission. Uvalde, Texas.

Nelson, M.R.

1968 Nail Chronology as an Aid to Dating Old Buildings. Technical Leaflet, No 48. American Association for State and Local History, Nashville. 
Notson, W. M.

1974 Fort Concho Medical History, 1869 to 1872. Fort Concho Preservation and Museum, San Angelo, Texas.

Ordnance Department U.S.A.

1874 Horse-Equipments, Cavalry Equipments and Accouterments, Saddlers, and Smith's Tools and Materials, and Standard Supply. Table of Ordnance Stores for the Cavalry Service; With the Action of the War Deparment Thereon. Ordnance Memoranda No. 18. Government Printing Office, Washington, D. C.

Orser, C. E., Jr.

1988 The Material Basis of the Postbellum Tenant Plantation. University of Georgia Press, Athens.

Otto, J. S.

1975 Status Differences and the Archaeological Record-A Comparison of Planter, Overseer, and Slave Sites from Cannon's Point Plantation (1794-1861), St. Simons Island, Georgia. Ph.D. dissertation, University of Florida, Gainesville.

1977 Artifacts and Status Difference-A Comparison of Ceramics from Planter, Overseer, and Slave Sites on an Antebellum Plantation. In Research Strategies in Historical Archaeology, edited by S. South, pp. 91-118. Academic, New York.

1984 Cannon's Point Plantation, 1974-1860: Living Conditions and Status Patterns in the Old South. Academic, New York.

Payne, D.

1970 Camp Life in the Army of Occupation: Corpus Christi, July 1845 to March 1846. Southwestern Historical Quarterly 73(3):326-342.

Prewitt, E. R.

1981 Cultural Chronology in Central Texas. Bulletin of the Texas Archeological Society 52:65-89.

1985 From Circleville to Toyah: Comments on Central Texas Chronology. Bulletin of the Texas Archeological Society 54:201-238.

1995 Distribution of Typed Projectile Points in Texas. Bulletin of the Texas Archeological Society 66:83173.

Quartermaster General

1986 U.S. Army Uniforms and Equipment, 1889: Specifications for Clothing, Camp and Garrison Equipage, Clothiong and Equipage Materials. Lincoln, University of Nebraska Press.

Rathje, W. L.

1971 The Origin and Development of Lowland Classic Maya Civilization. American Antiquity 36(3):275285.

Reedstrom, E. L.

1992 Apache Wars: An Illustrated Battle History. Sterling Publishing, New York.

Reitz, E. J.

1994 Zooarchaeological Analyšis of a Free African Community: Gracia Real de Santa Teresa de Mose. Historical Archaeology 28(1):23-40. 
Ricklis, R. A., and M. B. Collins

1994 Archaic and Late Prehistoric Human Ecology in the Middle Onion Creek Valley, Hays County, Texas. Studies in Archeology 19. Texas Archeological Research Laboratory, The University of Texas at Austin.

Robinson, W. B.

1986 U. S. Forts on the Texas Frontier. Texas Architect.

Sabloff, J. A., and W. L. Rathje

1975 The Rise of the Maya Merchant Class. Scientific American 233:72-82.

Santleben, A.

1994 [1910] A Texas Pioneer: Early Staging and Overland Freighting Days on the Frontiers of Texas and Mexico. Neale, New York. Republished by the Castro Colonies Heritage Association, Castroville, Texas.

Saunders, J.

1982 The Material Manifestations of Social Stratification among Tenant Farming Families. In Settlement of the Prairie Margin: Archaeology of the Richland Creek Reservoir, Navarro and Freestone Counties, Texas, 1980-1981, edited by L. M. Raab, pp. 179-189. Archaeological Monographs, Number 1. Archaeological Research Program, Southern Methodist University, Dallas.

Schubert, F. N.

1997 Black Valor: Buffalo Soldiers and the Medal of Honor, 1870-1898. Scholarly Resources, Wilmington, Delaware.

Schubert, F. N., editor

1995 On the Trail of the Buffalo Soldier: Biographies of African Americans in the U.S. Army, 1866-1917. Scholarly Resources, Wilmington, Delaware.

Schuyler, R. L. (editor)

1980 Archaeological Perspectives on Ethnicity in America. Baywood Publishing, Farmingdale, New York.

Shafer, H. J.

1977 Art and Territoriality in the Lower Pecos Region, Texas. Plains Anthropologists 22:13-22.

Skinner, S. A.

1981 Aboriginal Demographic Changes in Central Texas. Plains Anthropologists 26:111-118.

South, S.

1977 Method and Theory in Historical Archaeology. Academic, New York.

Spencer-Wood, S. M. (editor)

1987 Consumer Choice in Historical Archaeology. Plenum, New York.

Spivey, T., C. R. Ferring, D. J. Crouch, and K. Franklin

1977 Archaeological Investigations Along the Waurika Pipeline. Contributions at the Museum of the Great Plains No. 5. Lawton, Oklahoma. 
Steele, D. G., and C. Assad-Hunter

1986 Analysis of Vertebrate Faunal Remains from 41MC222 and 41MC296, McMullen County, Texas, Appendix III. In The Prehistoric Sites at Choke Canyon Reservoir, Southern Texas: Results of Phase II Archaeological Investigations, by G. D. Hall, T. R. Hester, and S. L. Black. Choke Canyon Series, No. 10. Center for Archaeological Research, The University of Texas at San Antonio.

Story, D. A.

1985 Adaptive Strategies of Archaic Cultures of the West Gulf Coastal Plain. In Prehistoric Food Production in North America, edited by R. I. Ford, pp. 19-56. Anthropological Papers, No. 75. Museum of Anthropology, University of Michigan, Ann Arbor.

Tate, M. I.

1996 Black Seminole Scouts. In The New Handbook of Texas in Six Volumes, edited by R. Tyler, pp. 572573. Texas State Historical Association, Austin.

Tetzlaff, O. W.

1979 [1846] The Emigrant to Texas: A Handbook and Guide. Eakin, Burnet, Texas.

Texas Parks and Wildlife

1998 The Vegatation Types of Texas. http://www.tpwd.state.tx.us/admin/veg//intro.html

Thomas, G.

1975 Texas Plants-An Ecological Summary. In Texas Plants: An Checklist and Ecological Summary, by Gould, pp.7-14. Miscellaneous Publications 585/Revised. Texas Agricultural Experiment Station, Texas A \& M University, College Station.

Toulouse, J.H.

1971 Bottle Makers and Their Marks. Thomas Nelson, New York.

Toulouse, J. H., and J. R. Toulouse

1936 Pioneer Posts of Texas. Naylor, San Antonio.

Tyler, R. (editor)

1996 The New Handbook of Texas in Six Volumes. Texas State Historical Association, Austin.

Utley, R. M.

1967 Frontiersmen in Blue: The United States Army and the Indian, 1848-1865. Macmillan, New York.

1973 Frontier Regulars: The United States Army and the Indian, 1866-1891. University of Nebraska, Lincoln.

Webb, W. P.

1965 The Texas Rangers: A Century of Frontier Defense. University of Texas Press, Austin

Weir, F. A.

1976 The Central Texas Archaic. Unpublished Ph.D. dissertation in Anthropology, Washington State University, Pullman. 
Wiedenfeld, C. C., L. J. Barnhill, and C. J. Novosad

1970 Soil Survey of Runnels County, Texas. Soil Conservation Service, Department of Agriculture, Washington, D. C.

Williams, J. W. (Editor)

1953 Journey of the Leach Wagon Train Across Texas, 1857. West Texas Historical Association Yearbook, 29:115-177.

Wooster, R.

1987 Soldiers, Sutlers, and Settlers: Garrison Life on the Texas Frontier. Texas A\&M University Press, College Station. 


\section{Appendix A: 1870 and 1880 Census Data}

Table A-1. 1870 Census Data

\begin{tabular}{|c|c|c|c|c|c|c|}
\hline Name & Race & $\mathbf{M} / \mathbf{S}$ & Age & Occupation & \multicolumn{2}{|c|}{ Birth Place } \\
\hline Allen, William & $\mathrm{W}$ & $S$ & 32 & Musician 11th & VT & USA-North \\
\hline Allen, Joseph M. & W & $S$ & 21 & Private Co. G 4th & $\mathrm{TX}$ & USA-South \\
\hline Allen, William C. & W & $S$ & 25 & Private Co. E 4th & NY & USA-North \\
\hline Altmore, Speino & W & $\mathrm{S}$ & 22 & Private Co. M 4th & $\mathrm{PA}$ & USA-Nor \\
\hline Anderson, Henry C. & W & $S$ & 27 & Sergeant Co. E 4th Cav & $\mathrm{PA}$ & USA-Nor \\
\hline Anderson, Thomas & W & $S$ & 25 & Wagoner Co. G 4th & NY & USA-Nor \\
\hline Andre, Mason & $\mathrm{W}$ & $S$ & 25 & Private Co. B 11th & Fra. & Europe \\
\hline Anz, Albert & $\mathrm{W}$ & $S$ & 29 & Private Co. G 4th & Bad. & Europe \\
\hline Arild, Frank & W & $\mathrm{S}$ & 25 & Private Co. E 11th Inftry & NY & USA-North \\
\hline Armstrong, John & $\mathrm{W}$ & $S$ & 21 & Private Co. B 4th & Ire. & UK \\
\hline Arnold, James & W & $\mathrm{S}$ & 24 & Private Co. M 4th & $\mathrm{PA}$ & USA-Nort \\
\hline Arnold, Fredrick & W & $S$ & 22 & Private Co. F 4th & Eng. & UK \\
\hline Ashton, Joseph & W & $S$ & 28 & Private Co. F 4th & PA & USA-Nort \\
\hline Baimson, William H. & W & $S$ & 22 & Corporal Co. M 4th & NY & USA-Nort \\
\hline Baker, Henry & $\mathrm{W}$ & $S$ & 24 & Private Co. F 4th & LA & USA-Sout \\
\hline Banchus, Isaac M. & $\mathrm{W}$ & $S$ & 21 & Private Co. F 4th & PA & USA-Nort \\
\hline Barlow, William & W & $S$ & 22 & Corporal Co. G 4th & Can. & Canada \\
\hline Barrett, Michael & W & $S$ & 26 & Private Co. G 4th & MI & USA-North \\
\hline Basner, Peter & W & $S$ & 23 & Private Co. B 11th & Pru. & Europe \\
\hline Bates, Charles E. & $\mathrm{W}$ & $S$ & 29 & Sergeant Co. E 4th Cav & $\mathrm{CT}$ & USA-North \\
\hline Bates, Charles & W & $S$ & 25 & Private Co. B 4th & Pru. & Europe \\
\hline Bauer, Charles & W & $S$ & 30 & Musician 11th & Wur. & Europe \\
\hline Baughton, James & W & $S$ & 21 & Trumpeter Co. M 4th & $\mathrm{CT}$ & USA-North \\
\hline Bayless, William C. & W & $S$ & 23 & 1st Lt., 4th Cav & $\mathrm{DC}$ & USA-North \\
\hline Beach, Warren D. & W & $S$ & 23 & 1st Lt., 11 th Inftry & NY. & USA-North \\
\hline Bearback, James & W & $S$ & 22 & Private Co. G 4th & Fra. & Europe \\
\hline Beber, John & W & $S$ & 29 & Private Co. M 4th & Sax. & Europe \\
\hline Becker, Freedore & W & $S$ & 37 & Private Co. G 4th & Old. & Europe \\
\hline Benson, Henry & W & $S$ & 36 & Private Co. B 4th & $\mathrm{OH}$ & USA-Nort \\
\hline Bercham, Peter & W & $S$ & 24 & Private Co. F 4th & Can & Canada \\
\hline Bills, Joseph & W & $\mathrm{S}$ & 37 & Private Co. $M$ 4th & Eng. & UK \\
\hline Bilo, Philip & W & $S$ & 25 & Artificer 11th & Pru. & Europe \\
\hline Bishap, Philip & W & $S$ & 39 & Private Co. E 4th & NJ & USA-North \\
\hline Black, Thomas & W & $S$ & 24 & Private Co. E 11 th Inftry & Ire. & UK \\
\hline Blood, Clark T. & W & $S$ & 29 & Private Co. F 4th & MA & USA-North \\
\hline Blossom, Charles & W & $S$ & 21 & Private Co. E 11th Inftry & $\mathrm{OH}$ & USA-North \\
\hline Blum, Peter & $\mathrm{W}$ & $S$ & 25 & Musician 11th & Pru & Europe \\
\hline Blun trill, Henry & W & $S$ & 24 & Private Co. M 4th & Cob. & Europe \\
\hline
\end{tabular}


Table A-1. continued

\begin{tabular}{|c|c|c|c|c|c|c|}
\hline Name & Race & $\mathbf{M} / \mathbf{S}$ & Age & Occupation & \multicolumn{2}{|c|}{ Birth Place } \\
\hline Bock, Conrad & W & $S$ & 24 & Private Co. I 4th & Pru. & Europe \\
\hline Borner, Jacob & W & $S$ & 28 & Private Co. E 4th & Bad. & Europe \\
\hline Boulses, John & W & $S$ & 38 & Private Co. B 4th & Aus. & Europe \\
\hline Bowman, Edward & W & $S$ & 23 & Private Co. B 4th & VA & USA-South \\
\hline Bowner, Charles & W & $S$ & 31 & Private Co. B 4th & MA & USA-North \\
\hline Boyd, Charles F. & W & $\mathrm{S}$ & 28 & Private Co. M 4th & $\mathrm{MD}$ & USA-South \\
\hline Boyd, William S. & W & $S$ & 21 & Private Co. E 11th Inftry & $\mathrm{TN}$ & USA-South \\
\hline Boyle, James & W & $S$ & 22 & Private Co. M 4th & DC & USA-North \\
\hline Braden, Joseph & W & $S$ & 24 & Private Co. F 4th & Eng. & UK \\
\hline Brady, Louis & W & $S$ & 23 & Private Co. B 4th & VA & USA-South \\
\hline Bran den, Henry & W & $S$ & 27 & Private Co. B 4th & Pru. & Europe \\
\hline Braners, Martin & W & $S$ & 33 & Private Co. E 4th & Han. & Europe \\
\hline Brannigan, John & W & $S$ & 34 & Private Co. B 11th & Sco. & UK \\
\hline Brautner, Charles F. & W & $S$ & 21 & Private Co. B 11th & $\mathrm{OH}$ & USA-North \\
\hline Bridges, Perry & W & $S$ & 21 & Private Co. $\mathrm{H} 11$ th & IN & USA-North \\
\hline Briggs, John & W & $S$ & 24 & Private Co. G 4th & PA & USA-North \\
\hline Brigs, Lewis & W & $S$ & 24 & Private Co. E 11th Inftry & $\mathrm{OH}$ & USA-North \\
\hline Briner, John C. & W & $S$ & 24 & Private Co. F 4th & PA & USA-North \\
\hline Brintona, Charly B. & W. & $S$ & 34 & Sergeant 11th & Pru. & Europe \\
\hline Brissett, Frank J. & W & $S$ & 25 & Private Co. E 4th & Can. & Canada \\
\hline Brown, Joseph K. & W & $S$ & 23 & Private Co. M 4th & NY & USA-North \\
\hline Brown, Fredrick & $\mathrm{W}$ & $S$ & & Saddler Co. G 4th & Eng. & UK \\
\hline Brown, Henry & $\mathrm{W}$ & $S$ & 24 & Private Co. F 4th & PA & USA-North \\
\hline Brown James M. & W & $S$ & 29 & Corporal Co. B 4th & Eng. & UK \\
\hline Bruren, Iheluss & W & $S$ & 27 & Private Co. E 4th & Pru. & Europe \\
\hline Budd, Otho W. & W & $S$ & 28 & 2nd Lieut. 4th Cav. & PA & . USA-North \\
\hline Burdell, Lapade & $\mathrm{W}$ & $S$ & 23 & Sergeant Co. B 4th & VA & USA-South \\
\hline Burns, Frank & $\mathrm{W}$ & $S$ & 23 & Private Co. M 4th & Eng. & UK \\
\hline Burns, Willard I. & W & $S$ & 21 & Private Co. B 4th & WI & USA-North \\
\hline Byson, David & $\mathrm{W}$ & $S$ & 27 & Private Co. E 4th & Ire, & UK \\
\hline Carr, Joseph I. & W & $S$ & 21 & Private Co. I 4th & PA & USA-North \\
\hline Carr, George W. & $\mathrm{W}$ & $S$ & 22 & Private Co. $\mathrm{H} 11$ th & $\mathrm{OH}$ & USA-North \\
\hline Carter, James R. Q. & $\mathrm{W}$ & $S$ & 23 & Trumpeter 4th & PA & USA-North \\
\hline Casack, Francis & $\mathrm{W}$ & $S$ & 27 & Private Co. E 4th & Ire. & UK \\
\hline Case, James & $\mathrm{W}$ & $S$ & 24 & Sergeant Co E 11 th & $\mathrm{IN}$ & USA-North \\
\hline Caston, William & $\mathrm{W}$ & $S$ & 25 & Private Co. E 11th Inftry & N.S. & Canada \\
\hline Chevelly, Samual & W & $S$ & 21 & Private Co. M 4th & Fra. & Europe \\
\hline Clancy, James & W & S & 29 & Sergeant Co. M 4th & Ire. & UK \\
\hline Clark, Frank H. & W & $S$ & 24 & Musicians 11th Infantry & NY & USA-North \\
\hline Clayton, James H. & $\mathrm{W}$ & $\mathrm{S}$ & 25 & Corporal Co. F 4th & PA & USA-North \\
\hline
\end{tabular}


Table A-1. continued

\begin{tabular}{|c|c|c|c|c|c|c|}
\hline Name & Race & $\mathbf{M} / \mathbf{S}$ & Age & Occupation & \multicolumn{2}{|c|}{ Birth Place } \\
\hline Cloud, James R. & $\mathrm{W}$ & $S$ & 41 & Guide for US Troops & $\mathrm{TN}$ & USA-North \\
\hline Coffy, Dennis & $\mathrm{W}$ & $S$ & 25 & Private Co. B 11th & Ire. & UK \\
\hline Coggins, John & W & $S$ & 21 & Private Co. B 4th & Ire. & UK \\
\hline Coleman, John & W & $S$ & 26 & Private Co. B 4th & Ire. & UK \\
\hline Colgan, John & W & $S$ & 38 & Private Co. M 4th & Ire. & UK \\
\hline Collins, Richard & W & $S$ & 28 & Corporal Co. M 4th & Ire. & UK \\
\hline Connay, John & $\mathrm{W}$ & $S$ & 34 & Private Co. G 4th & Ire. & UK \\
\hline Conner, Phillip & $\mathrm{W}$ & $S$ & 25 & Private Co. G 4th & Ire. & UK \\
\hline Conrad, Joseph & W & $S$ & 41 & Captain Co. B 11th Inftry & War. & Europe \\
\hline Conway, Joseph & W & $S$ & 23 & Private Co. I 4th & Ire. & UK \\
\hline Conway, Daniel & W & $S$ & 21 & Private Co. B 11th & Ire. & UK \\
\hline Cooley, John W. & W & $S$ & 21 & Private Co. H 11th & IN & USA-North \\
\hline Coon, Anthony & $\mathrm{W}$ & $S$ & 23 & Private Co. M 4th & NY & USA-North \\
\hline Cowgill, George W. & W & $S$ & 27 & Private Co. M 4th & $\mathrm{TN}$ & USA-South \\
\hline Cox, Francis & W & $S$ & 24 & Private Co. E 11th Inftry & IN & USA-North \\
\hline Crabtree, Vincent & W & $S$ & 32 & Private Co. E 4th & Eng. & UK \\
\hline Crane, Charles & W & $S$ & 24 & Private Co. I 4th & $\mathrm{OH}$ & USA-North \\
\hline Cranston, John & W & $S$ & 28 & Private Co. E 4th & Ire. & UK \\
\hline Crillon, Thomas & W & $S$ & 23 & Private Co. M 4th & Eng. & UK \\
\hline Croft, Adolph & W & S & 24 & Private Co. B 4th & Pru. & Europe \\
\hline Croft, Reinault & W & $S$ & 26 & Private Co. B 4th & Pru. & Europe \\
\hline Crosser, Charles & W & $S$ & 22 & Trumpeter Co. G 4th & PA & USA-North \\
\hline Cunningham, John & W & $S$ & 25 & Musician 11th & NY & USA-North \\
\hline Dale, Alfred L. & W & $S$ & 23 & Private Co. B 11th & $\mathrm{OH}$ & USA-North \\
\hline Daling, Earl A. & W & $S$ & 21 & Private Co. $M$ 4th & MA & USA-North \\
\hline Darcy, John I. & W & $S$ & 23 & Private Co. I 4th & Ire. & UK \\
\hline Darns, Thomas & W & $S$ & 21 & Private Co. M 4th & PA & USA-North \\
\hline Daune, James & $\mathrm{W}$ & $S$ & 26 & Private Co. G 4th & NY & USA-North \\
\hline Davis, Charles C. & W & $S$ & 26 & Sergeant Co. B 11th & $\mathrm{ME}$ & USA-North \\
\hline Davis, Franklin & $\mathrm{W}$ & $S$ & 23 & Private Co. B 11th & $\mathrm{OH}$ & USA-North \\
\hline Davis, Goerge W. & W & $S$ & 25 & Private Co. H 11th & $\mathrm{OH}$ & USA-North \\
\hline Dawney, William & W & $S$ & 29 & Private Co. G 4th & Ire. & UK \\
\hline Deny, Patrick & W & $S$ & 26 & Sergeant Co. H 11th & Ire. & UK \\
\hline Dichet, Anthony & $\mathrm{W}$ & $S$ & 44 & Private Co. G 4th & Fin. & Europe \\
\hline Dick, George A. & $\mathrm{W}$ & $S$ & 34 & Private Co. E 11 th Inftry & Pru & Europe \\
\hline Dillon, Redmond & W & $S$ & 40 & Wagoner Co. B 11th & Ire. & UK \\
\hline Dillon, Joseph A. & W & $\mathbf{S}$ & 25 & Private Co. H 11th & $\mathrm{OH}$ & USA-North \\
\hline Dillon, Thomas & W & $S$ & 23 & Private Co. I 4th & MA & USA-North \\
\hline Dolan, John & W & $S$ & 40 & 1st Sergeant Co. B 4th & Ire. & UK \\
\hline Dolen, Michael & W & $S$ & 28 & Private Co. E 11th Inftry & Ire. & UK \\
\hline
\end{tabular}


Table A-1. continued

\begin{tabular}{|c|c|c|c|c|c|c|}
\hline Name & Race & $\mathbf{M} / \mathbf{S}$ & Age & Occupation & \multicolumn{2}{|c|}{ Birth Place } \\
\hline Domrey Patrick & W & $S$ & 27 & Sergeant Co. G 4th & Ire. & UK \\
\hline Dosher, Augustus & W & $S$ & 36 & Q. M. Srgnt. Co. E4th Cav & Pru. & Europe \\
\hline Dougherty, James J. & W & $S$ & 25 & Sergeant Co. B 4th & Ire. & UK \\
\hline Doyle, David & W & $S$ & 21 & Trumpeter C. M 4th & Sco. & UK \\
\hline Doyle, John & W & $S$ & 24 & Wagoner Co. M 4th & MD & USA-South \\
\hline Duane, George & W & $S$ & 23 & Private Co. H 11th & Eng. & UK \\
\hline Duffy, William & W & $S$ & 27 & Private Co. E 4th & PA & USA-North \\
\hline Duggins, Henry A. & $\mathrm{W}$ & $S$ & 24 & Musician 11th & IN & USA-North \\
\hline Dull, Cornelius C. & W & $S$ & 21 & Private Co. $M$ 4th & PA & USA-North \\
\hline Duncan, Samual & W & $S$ & 24 & Private Co. E 4th & Ire. & UK \\
\hline Dune, John & W & $S$ & 36 & Private Co. E 11th Inftry & Ire. & UK \\
\hline Eardman, George & $\mathrm{W}$ & $S$ & 24 & Private Co. G 4th & PA & USA-North \\
\hline Edwards, Thomas & W & $S$ & 21 & Private Co. M 4th & Eng. & UK \\
\hline Eicilburger, Peter J. & $\mathrm{W}$ & $S$ & 23 & Sergeant Co. E 4th Cav & $\mathrm{MD}$ & USA-South \\
\hline Ele, John Peter & $\mathrm{W}$ & $S$ & 21 & Private Co. B 4th & Can. & Canada \\
\hline Elsky, Thomas & $\mathrm{W}$ & $S$ & 24 & Private Co. I 4th & Eng. & UK \\
\hline Eppenzoller, Lottlieb & $\mathrm{W}$ & $S$ & 24 & Corporal Co. G 4th & Wur. & Europe \\
\hline Essex, Arnold & $\mathrm{W}$ & $S$ & 46 & Musician 11th & Pru. & Europe \\
\hline Esslinger, Adolph & $\mathrm{W}$ & $S$ & 21 & Private Co.I 4th & Swi. & Europe \\
\hline Farrow, Joseph & W & $S$ & 24 & Private Co. B 11th & VT & USA-North \\
\hline Ferguson, John & $\mathrm{W}$ & $S$ & 24 & Private Co. E 11th Inftry & IN & USA-North \\
\hline Fitzgerald, Thomas C. & $\mathrm{W}$ & $S$ & 38 & Private Co. B 11th & NY & USA-North \\
\hline Fitzpatrick, Thomas & $\mathrm{W}$ & $S$ & 25 & Private Co. E 4th & Ire. & UK \\
\hline Fitzsimons, Francis & $\mathrm{W}$ & $S$ & 25 & Private Co. B 4th & $\mathrm{PA}$ & USA-North \\
\hline Fitzsimons, Thomas & W & $S$ & 33 & Private Co. E 11th Inftry & Ire. & UK \\
\hline Flattery, John & $\mathrm{W}$ & $S$ & 27 & Private Co. E 4th & Ire. & UK \\
\hline Flien, James & W & $S$ & 23 & Private Co. B 4th & PA & USA-North \\
\hline Flood, Michael & $\mathrm{W}$ & $S$ & 25 & Private Co. M 4th & Ire. & UK \\
\hline Foley, John & $\mathrm{W}$ & $S$ & 26 & Corporal Co. G 4th & Ire. & UK \\
\hline Forbs, William & $\mathrm{W}$ & $S$ & 40 & Private Co. E 11th Inftry & PA & USA-North \\
\hline Forbs, Erastins, W. & W & $S$ & 27 & Private Co. E 4th & NH & USA-North \\
\hline Forder, Henry & W & $S$ & 21 & Private Co. M 4th & PA & USA-North \\
\hline Fort, William A. & W & $S$ & 35 & Private Co. E 4th & GA & USA-South \\
\hline Fowler, William & W & $S$ & 39 & 2nd Sergeant. Co. B 11th & Old. & Europe \\
\hline Franklin, John & $\mathrm{W}$ & $S$ & 32 & Private Co. H 11 th & Swe. & Europe \\
\hline Franleit, August & W & $S$ & 33 & Sergeant Co. B 11th & Han. & Europe \\
\hline Fredrickson, Fredrick & $\mathrm{W}$ & $S$ & 23 & Sergeant Co. M 4th & Den. & Europe \\
\hline Friedel, Teadore & W & $S$ & 26 & Corporal Co. F 4th & $\mathrm{OH}$ & USA-North \\
\hline Frith, Henry & W & $S$ & 23 & Private Co. H 11th & Sco. & UK \\
\hline Fritz, Benjamin F. & $\mathrm{W}$ & $S$ & 23 & Private Co. B 11th & PA & USA-North \\
\hline
\end{tabular}


Table A-1. continued

\begin{tabular}{|c|c|c|c|c|c|c|}
\hline Name & Race & $\mathbf{M} / \mathbf{S}$ & Age & Occupation & & irth Place \\
\hline Fritzs, Henry W. & $\mathrm{W}$ & $S$ & 29 & 1st Sergeant Co. M 4th & $\mathrm{OH}$. & USA-North \\
\hline Frothingham Charles H. & $\mathrm{W}$ & $S$ & 29 & Private Co. E 4th & MA & USA-North \\
\hline Gallaghen, Simon I. & W & $S$ & 35 & Private Co. B 11th & Ire. & UK \\
\hline Gallagher, Charles & W & $S$ & 25 & Private Co. M 4th & Ire. & UK \\
\hline Garling, John & W & $S$ & 36 & Private Co. $\mathrm{H} 11$ th & $\mathrm{PA}$ & USA-North \\
\hline Geck, Henry & W & $S$ & 26 & Private Co. G 4th & Bad. & Europe \\
\hline Gillem, Alven I. & $\mathrm{W}$ & $\mathrm{M}$ & 40 & 11th Inftry Bvt Maj Gen & TN. & USA-South \\
\hline Gilmore, Micheal F. & $\mathrm{W}$ & $S$ & 24 & Corporal Co. M 4th & NY & USA-North \\
\hline Gilmore, Charles & W & $S$ & 38 & Private Co. I 4th & Ire. & UK \\
\hline Giso, Jacob & W & $S$ & 24 & Private Co. I 4th & Pru. & Europe \\
\hline Gleason, John & W & $S$ & 26 & Private Co. M 4th & Ire. & UK \\
\hline Glocby, Michael & W & $S$ & 24 & Private Co. E 11th Inftry & PA & USA-North \\
\hline Gordan, Lew is C. & W & $S$ & 35 & Blacksmith Co. M 4th & NY & USA-North \\
\hline Gowner, John & W & $S$ & 32 & Private Co. E 11th Inftry & Eng. & UK \\
\hline Gradie, David & W & $S$ & 21 & Private Co. H 11th & $\mathrm{OH}$ & USA-North \\
\hline Granes, Benjamin F. & W & $S$ & 26 & Sergeant Co. B 4th & $\mathrm{AL}$ & USA-South \\
\hline Grant, Henry $\mathrm{H}$. & W & $S$ & 37 & Private Co. E 4th & Sco. & UK \\
\hline Grant, James & W & $S$ & 23 & Private Co. H 11th & Ire. & UK \\
\hline Grenmis, George & W & $\mathrm{S}$ & 24 & Private Co. E 11th Inftry & NY & USA-North \\
\hline Grgy, Clifford & $\mathrm{W}$ & $S$ & 30 & Private Co. G 4th & $\mathrm{CT}$ & USA-North \\
\hline Gross, John & W & $S$ & 39 & Private Co. M 4th & Bad. & Europe \\
\hline Grover, Alfred & W & $S$ & 22 & Private Co. B 4th & $\mathrm{MD}$ & USA-South \\
\hline Gutridge, Edward & $\mathrm{W}$ & $S$ & 25 & Private Co. E 4th & Ire. & UK \\
\hline Hack, John J. & $\mathrm{W}$ & $\mathrm{S}$ & 31 & 1st Sergeant Co. E 4th & Wur. & Europe \\
\hline Hadder, Samual J. & W & $S$ & 35 & Private Co. B 4th & $\mathrm{OH}$ & USA-North \\
\hline Haley, Charles H & W & $S$ & 29 & Corporal Co. F 4th & $\mathrm{ME}$ & USA-North \\
\hline Haley, Cornllus & W & $S$ & 25 & Private Co. M 4th & Ire. & UK \\
\hline Haley, James & W & $S$ & 33 & Private Co. B 11th & Ire. & UK \\
\hline Hall, Joseph & W & $S$ & 26 & Private Co. H 11th & Ire. & UK \\
\hline Hamilton, John B. & W & $S$ & 30 & Sergeant Co E 11 th & Sco. & UK \\
\hline Hamilton, Alexander & W & $S$ & 31 & Private Co. $\mathrm{M} 4$ th & Sco. & UK \\
\hline Hamit, John & W & $S$ & 24 & Corporal 11th & PA & USA-North \\
\hline Hand, Joseph & W & $S$ & 21 & Private Co. H 11th & $\mathrm{OH}$ & USA-North \\
\hline Hanes, Ira L. & W & $S$ & 24 & Private Co. $\mathrm{H} 11$ th & $\mathrm{OH}$ & USA-North \\
\hline Hard, Charles S. & W & $S$ & 24 & Musician 11th & MA & USA-North \\
\hline Hardigan, John & W & $S$ & 25 & Private Co. I 4th & Ire. & UK \\
\hline Harding, Charles & $\mathrm{W}$ & $S$ & 32 & Private Co. M 4th & $\mathrm{MD}$ & USA-South \\
\hline Hardy, Thomas & $\mathrm{W}$ & $S$ & 30 & Private Co. I 4th & Ire. & UK \\
\hline Harrington, Daniel I. & $\mathrm{W}$ & $S$ & 24 & Sergeant Co. M 4th & Ire. & UK \\
\hline Hartman, Enock C. & W & $S$ & 30 & Private Co. B 4th & PA & USA-North \\
\hline
\end{tabular}


Table A-1. continued

\begin{tabular}{|c|c|c|c|c|c|c|}
\hline Name & Race & $\mathbf{M} / \mathbf{S}$ & Age & Occupation & \multicolumn{2}{|c|}{ Birth Place } \\
\hline Hasset, Miguil & $\mathrm{W}$ & $S$ & 25 & Private Co. E 4th & Ire. & UK \\
\hline Hatch, John P. & W & $S$ & 48 & Maj./Brt. Brig. Gen. 4th Cav. & NY & USA-North \\
\hline Hauer, Fredrick & W & $S$ & 29 & Private Co. B 11th & Pru. & Europe \\
\hline Healey, Thomas & W & $S$ & 24 & Corporal Co. B 11th & $\mathrm{MD}$ & USA-South \\
\hline Heems, Michael & W & $S$ & 28 & Private Co. I 4th & LA & USA-South \\
\hline Heiberich, John & W & $\mathrm{S}$ & 29 & 1st Sergeant Co. F 4th & Bav. & Europe \\
\hline Held, Peter & W & $\mathrm{S}$ & 30 & Private Co. B 4th & Pru. & Europe \\
\hline Hemphill William C. & W & $S$ & 38 & 1st Lt. Co. G 4th & VA. & USA-South \\
\hline Henny, Charles & W & $S$ & 21 & Sergeant Co. M 4th & NY & USA-North \\
\hline Hesslip, Essay & W & $S$ & 25 & Private Co. B 4th & VA & USA-South \\
\hline Hick, William R. & W & $S$ & 33 & 1st Lieut. 4th Cavalry & NJ & USA-North \\
\hline Higlich, Charles & W & $S$ & 28 & 2st Sergeant Co. H 11th & Den. & Europe \\
\hline Hill, Robert A. & W & $S$ & 24 & Private Co. B 11th & VA & USA-South \\
\hline Hill, William S. & W & $S$ & 21 & Corporal Co. B 4th & VA & USA-South \\
\hline Hilondorff, Charles W. & W & $S$ & 33 & Private Co. B 11th & KY & USA-South \\
\hline Hiutwig, John A. & W & $S$ & 24 & Musician 11th & Hun. & Europe \\
\hline Hoffman, William & W & $S$ & 31 & 1st Lt. 11th Inftry. & Me. & USA-North \\
\hline Hoffman, Benjamin F. & W & $S$ & 28 & Corporal Co. B 4th & PA & USA-North \\
\hline Hofsas, Christ & W & $S$ & 23 & Private Co. B 11th & Wur. & Europe \\
\hline Holmes, Elmore & W & $S$ & 24 & Private Co. E 11th Inftry & NY & USA-North \\
\hline Hounshall, Dia G. & W & $S$ & 28 & Private Co. B 11th & WV & USA-South \\
\hline Hubert, William & W & $S$ & 26 & 1st Sergeant Co. B 11th & NY. & USA-North \\
\hline Hughes, Peter $\mathrm{H}$ & W & $S$ & 28 & Private Co. M 4th & Ire. & UK \\
\hline Hynes, Dominick & W & $S$ & 24 & Private Co. B 11th & Ire. & UK \\
\hline Hynson, Henry C. & W & $S$ & 26 & Forge Contractor US Troops & AR & USA-South \\
\hline Hynson, John & W & $S$ & 27 & Forge Contractor US Troops & $\mathrm{AR}$ & USA-South \\
\hline Jackson, Charles & W & $S$ & 21 & Private Co. E 11th Inftry & $\mathrm{OH}$ & USA-North \\
\hline Jackster, Robert & W & S & 21 & Private Co. G 4th & Ire. & UK \\
\hline Jacoby, Edward & W & $S$ & 21 & Private Co. M 4th & Bad. & Europe \\
\hline Jenkins, Benjamin & W & $S$ & 30 & Sergeant Co. G 4th & MD & USA-South \\
\hline Jmhof, Joseph & W & $S$ & 42 & Musician 11th & Swi. & Europe \\
\hline Johnson, Earl W. & W & $S$ & 21 & Private Co. G 4th & IA & USA-North \\
\hline Johnson, Theodore & W & $S$ & 21 & Private Co. M 4th & $\mathrm{OH}$ & USA-North \\
\hline Johnson, William & W & $S$ & 31 & Private Co. M 4th & Eng. & UK \\
\hline Jones, Lew is & W & $S$ & 21 & Private Co. E 11th Inftry & $\mathrm{OH}$ & USA-North \\
\hline Jones, William & W & $S$ & 38 & Private Co. I 4th & Ire. & UK \\
\hline Jones, Richard & W & $S$ & 27 & Sergeant Co. F 4th & Ire. & UK \\
\hline Jones, Laurence & W & $S$ & 27 & Private Co. M 4th & Ire. & UK \\
\hline Jordan, David & W & $S$ & 24 & Private Co. G 4th & Ire. & UK \\
\hline Joyce, Robert F. & W & $S$ & 32 & 1st Sergeant Co. H 11th & NY. & USA-North \\
\hline
\end{tabular}


Table A-1. continued

\section{Name}

Kassidy John

Kavenaugh, John

Kehoe, Daniel

Keiser, Paul

Kelly, Andrew J.

Kelly, Francis

Kelly, John

Kelly, Timothy

Kelly, Girand

Kelly, James

Kelser, Louis

Kemball, Charles

Kerr, Archibald

Kiloner, Jacob

King, William

King, Charles E.

King, William W.

King, William B.

King. Charles $\mathrm{H}$

Kline, Lewis

Knapp, Lew is

Knepperberger,Lenard

Knight, Charles N.

Kogler, George

Kratz, Hugo

Krenz, Henry

Kritmire, Herman

Lacpio, Charles L.

Lanahan, Cornelius

Lane, John $\mathrm{H}$.

Laporte, Lewis

Latheno, James

Lawrence, James

Lawson, Thomas

Lawson, Stearns

Leffler, William

Leino, John

Lewis, Fredrick

Lewis, William H.

Lionel, Lardae

\section{Race M/S Age Occupation}

W

W

W S

W S

W S

W S

W S

W S

W

W

W

W

W

W S

W S

W S

W S

W S

W S

W S

W S

W S

W S

W S

W S

W S

W S

W S

W S

W S

W S

W S

W S

W S

W S

W S

W S

W S

W S

W S

W S

29

Corporal Co. B 4th

Private Co. B 11th

Private Co. B 4th

Private Co. E 11th Inftry

Private Co. H 11th

Trumpeter Co. F 4th

Private Co. G 4th

Private Co. M 4th

Private Co. B 4th

Private Co. B 4th

Sergeant Co. F 4th

Private Co. B 11th

Private Co. E 4th

Trumpeter 4th

Private Co. B 4th

Private Co. M 4th

Trumpeter Co. F 4th

Private Co. M 4th

Corporal Co. B 4th

Private Co. I 4th

Private Co. B 4th

Artificer 4th

A.A. Surgeon US Army

Musician Co. H 11th

Sergeant Co. B 4th

Private Co. E 4th

Private Co. B 4th

2nd Lt. 11th Inftry.

Private Co. M 4th

Private Co. B 4th

Private Co. G 4th

Private Co. B 11th

Sergeant Co. E 4th Cav

Private Co. B 4th

Saddle Co. M4th

Private Co. H 11th

Private Co. H 11th

Private Co. G 4th

Private Co. B 11th

Private Co. E 4th
Birth Place

Ire. UK

Ire. UK

Ire. UK

Swi. Europe

Eng. UK

PA USA-North

Ire. UK

RI USA-North

Fra. Europe

Eng. UK

MD USA-South

MA USA-North

VA USA-South

PA USA-North

KY USA-South

Ire. UK

PA USA-North

PA USA-North

VA USA-South

Pru. Europe

NY USA-North

Aus. Europe

TX USA-South

Bad Europe

Pru. Europe

Pru. Europe

Bav. Europe

NY USA-North

Ire. UK

Pru. Europe

Can. Canada

Eng. UK

NY USA-North

MS USA-South

$\mathrm{OH}$ USA-North

$\mathrm{OH}$ USA-North

Swi. Europe

Eng. UK

NY USA-North

MI USA-North 
Table A-1. continued

Name

Little, Joseph G.

Logan, Joseph

Lott, George G.

Luiden, Richard T

Lunny, Patrick

Lyden, William

Lyman, James

Lynch, Niell

Maag, John

Mack, Charles

Mackey, George

Magner, James

Maguire, John

Mallatt, Samual

Markling, Michael

Martin, Henry

Martins John $\mathrm{H}$

Mathey, Michael

McCam, Daniel

McCam, Charles

McCarthy, Patrick

McClark, James

McCloud, James $\mathrm{H}$.

McCoy, John A.

McCready, John

McCuno, Henry

McDowell, Charles

McFall, Thomas

McGann, Edward

McGenley, Hugh

McGoom, William

McGrath, John

McGuire, William

McHugh, Peter

McKenna, Patrick

McKeon, George

McLanesford, Josep

McLaughlin, Napoleon B.

McMahon, Patrick

McNally, John J.

\section{Race M/S Age Occupation}

W S 20 Private Co. B 4th

W S 21 Private Co. B 4th

W $\quad$ S 27 1st Lt. 11th

W $\quad$ S 21 Private Co. M 4th

W S 30 Private Co. M 4th

W $\quad$ S 27 Private Co. G 4th

W S 24 1st Sergeant Co E 11th

W S 24 Private Co. E 4th

W S 21 Private Co. B 11th

W S 22 Musician Co. B 11th

W $\quad$ S 37 Private Co. E 11th Inftry

W S 26 Private Co. B 4th

W S 21 Corporal 11th

W S 23 Private Co. B 4th

W $\quad$ S 21 Private Co. M 4th

W S 30 Corporal Co. E 4th Cav

W $S 28$ Private Co. I 4th

W $\quad$ S 37 Musician 11th

W S 23 Private Co. B 11th

W $\quad$ S 21 Private Co. B 11th

W $\quad$ S 30 Farrier Co. M 4th

W S

W S

W M

W S

W S

W $S$

W S

W S

W

W S

W S

W S

W S

W S

W S

W S

W

W

${ }^{-W}$

26

22

44

22

24

21

24

24

28

21

22

25

32

25

22

21

S 46

S 22

$\mathrm{S}$
Sergeant Co. G 4th

Private Co. H 11th

A.A. Surgeon

Private Co. E 11th Inftry

Wagoner 11th

Private Co. H 11th

Private Co. E 11th Inftry

1st Sergeant Co. G 4th

Private Co. M 4th

Private Co. E 4th

Private Co. E 4th

Private Co. E 4th

Private Co. M 4th

Corporal Co. G 4th

Private Co. I 4th

Private Co. H 11th

Capt. Brt. Brg. Gen.

Private Co. H 11th

Private Co. H 11th

\section{Birth Place}

Fra. Europe

LA USA-South

PA. USA-North

Can. Canada

Ire. UK

Ire. UK

Ire. UK

Ire. UK

Swi. Europe

NY USA-North

$\mathrm{OH}$ USA-North

Eng. UK

Eng. UK

$\mathrm{OH}$ USA-North

$\mathrm{OH}$ USA-North

MI USA-North

Hols Europe

Pru. Europe

NY USA-North

OH USA-North

Ire. UK

USA-South

$\mathrm{OH}$ USA-North

PA USA-North

KY USA-South

$\mathrm{OH}$ USA-North

Eng. UK

IN USA-North

Ire. UK

Ire. UK

ME USA-North

Ire. UK

$\mathrm{OH}$ USA-North

Ire. UK

MD USA-South

PA USA-North

IN USA-North

VT USA-North

Ire. UK

MA USA-North 
Table A-1. continued

\begin{tabular}{|c|c|c|c|c|c|c|}
\hline Name & Race & $\mathbf{M} / \mathbf{S}$ & Age & Occupation & \multicolumn{2}{|c|}{ Birth Place } \\
\hline McWilliams, Joseph & W & $S$ & 29 & Farrier Co. G 4th & Ire. & UK \\
\hline Meakey, Edward & $\mathrm{W}$ & $S$ & 22 & Musician 11th & Pru. & Europe \\
\hline Medsack,Fredrick & W & $S$ & 25 & Corporal 11th & Pru. & Europe \\
\hline Melby, Walter & $\mathrm{W}$ & $\mathrm{S}$ & 21 & Corporal Co. E 4th Cav & Eng. & UK \\
\hline Melvill, Andie & $\mathrm{W}$ & $S$ & 25 & Private Co. G 4th & MA & USA-North \\
\hline Mermot, William & $\mathrm{W}$ & $S$ & 23 & Trumpeter Co. G 4th & Bav. & Europe \\
\hline Merriam, Samual & W & $S$ & 23 & Private Co. E 4th & $\mathrm{NH}$ & USA-North \\
\hline Meyer, Albert L. & $\mathrm{W}$ & $S$ & 23 & 2nd Lt. Co. B 11th & NY & USA-North \\
\hline Meyer, Fredrick & W & $S$ & 35 & Private Co. G 4th & Han. & Europe \\
\hline Miller, William & $\mathrm{W}$ & $S$ & 22 & Corporal Co. E 4th Cav & $\mathrm{OH}$ & USA-North \\
\hline Minto, Robert & $\mathrm{W}$ & $S$ & 28 & Private Co. B 4th & Sco. & UK \\
\hline Mitchell, John & W & $S$ & 33 & Corporal Co. M 4th & KY & USA-South \\
\hline Moass, Adolph & W & $S$ & 35 & Private Co. B 4th & Pru. & Europe \\
\hline Mobety, David & W & $S$ & 23 & Private Co. I 4th & VA & USA-South \\
\hline Mobety, Lemuel B. & $\mathrm{W}$ & $S$ & 21 & Private Co. M 4th & IN & USA-North \\
\hline Mohs, Martin & W & $S$ & 39 & Private Co. B 4th & Ire. & UK \\
\hline Morgan, James & W & $S$ & 29 & Private Co. F 4th & Ire. & UK \\
\hline Morgan Charles & W & $\mathrm{s}$ & 24 & Saddler Co. G 4th & NY & USA-North \\
\hline Morgan, Samual M. & W & $S$ & 21 & Corporal Co. M 4th & NY & USA-North \\
\hline Moriaty, John & W & $S$ & 22 & Trumpeter Co. B 4th & PA & USA-North \\
\hline Morris, Charles & W & $S$ & 24 & Corporal 11th & PA & USA-North \\
\hline Motley, Joseph & W & $S$ & 22 & Private Co. G 4th & MD & USA-South \\
\hline Moux, William & W & $\mathrm{S}$ & 24 & Corporal Co. B 11th & NY & USA-North \\
\hline Muller Lewis & W & $S$ & 26 & Private Co. I 4th & PA & USA-North \\
\hline Munich, Peter & W & $S$ & 27 & Private Co. E 4th & Hol. & Europe \\
\hline Munsy, Henry & W & $S$ & 25 & Con Sergeant 11th & MA & USA-North \\
\hline Murphy, Thọmas & W & $S$ & 22 & Private Co. H 11th & $\mathrm{OH}$ & USA-North \\
\hline Murphy, John & W & $S$ & 21 & Corporal Co. M 4th & $\mathrm{OH}$ & USA-North \\
\hline Murphy, Phillip & W & $S$ & 26 & Corporal Co. M 4th & Ire. & UK \\
\hline Murthen, James & W & $\mathrm{S}$ & 33 & Private Co. B 4th & Ire. & UK \\
\hline Nall, William $\mathrm{H}$. & W & $\mathrm{S}$ & 21 & Private Co. B 4th & PA & USA-North \\
\hline Neill, Thomas & W & $\mathrm{S}$ & 21 & Private Co. B 4th & Ire. & UK \\
\hline Neimann, George & $\mathrm{W}$ & $S$ & 29 & Private Co. G 4th & Old & Europe \\
\hline Nelson, Fritz & W & $S$ & 29 & Private Co. E 4th & Den. & Europe \\
\hline Nelson, William & W & $S$ & 30 & Farrier 4th & Ire. & UK \\
\hline Newby, William & W & $S$ & 24 & Musician 11th & VA & USA-South \\
\hline Nixon, Thomas & W & S & 24 & Private Co. E 11th Inftry & MO & USA-South \\
\hline Norris, James & W & $S$ & 33 & Artificer Co. B 11th & Ire. & UK \\
\hline O'Brien John & W & $S$ & 27 & Private Co. G 4th & NY & USA-North \\
\hline O'Hana, John & W & $S$ & 22 & Private Co. E 4th & Ire. & UK \\
\hline
\end{tabular}


Table A-1. continued

\section{Name}

O'Hern, John

O'Neil, John C.

O'Neil, Henry

O'Neill, William

O'Rourke, Patrick

O'Shea, Patrick

O'Sullivan, John

Osioohl, Henry

Osmer, Nathan H.

Oster, John

Oswalt, George W.

Owens, Cornelius

Oxen, Charles

Pair, William

Palsen, James

Parks, James

Parrish, William

Pate, Henry

Paulsen, Henry

Perkins, Lewis

Pfaflin, George

Philo, David

Phoenix, Edwin

Pielman, Henry A.

Pilio, Anthony

Pirl, Fredrick

Piro, Charles H.

Polen, John T.

Power, Robert

Powers, Brady

Pratt, James H

Pritch, Fredrick

Qtricker, Daniel

Quimby, Ira

Quinn, Owen

Race, Henry B.

Radd, John $\mathrm{H}$

Rate, John

Ray, William

Ray, James $\mathrm{H}$.

\section{Race M/S Age Occupation}

W S 25 Private Co. G 4th

W S 35 Private Co. G 4th

W S 25 Private Co. G 4th

W S 22 Private Co. I 4th

W

W S

W S

W S

W S

W S

W S

W S

W S

W S

W S

W

W S

W S

W S

W S

W S

W

W S

W S

W S

W

W S

W

W S

W S

W S

W S

W S

W M

W S

W S

W S

W S

W S

W S
Private Co. E 11th Inftry

Private Co. I 4th

Private Co. I 4th

Private Co. I 4th

Private Co. G 4th

Private Co. I 4th

Sergeant Co. M 4th

Sergeant Co. B 4th

Corporal Co. F 4th

Wagoner Co. F 4th

Corporal 11th

Private Co. G 4th

Private Co. E 11th Inftry

Private Co. G 4th

Private Co. E 11th Inftry

Private Co. G 4th

Private Co. E 11th Inftry

Private Co. I 4th

Private Co. E 4th

Private Co. G 4th

Corporal Co. E 4th Cav

Private Co. E 11th Inftry

Wagoner 4th

Private Co. H 11th

Private Co. M 4th

Private Co. E 11th Inftry

Corporal Co. M 4th

Private Co. E 11th Inftry

Musician Co. B 11th

Regit g. M Inftry 1 st Lt.

Private Co. M 4th

Private Co. B 11th

Private Co. B 11th

Private Co. E 11th Inftry

Private Co. B 4th

Private Co. I 4th
Birth Place

Ire. UK

Ire. UK

DE USA-North

CT USA-North

Ire. UK

Ire. UK

Ire. UK

HeDa Europe

PA USA-North

Fra. Europe

IN USA-North

Ire. UK

Pru. Europe

GA USA-South

IN USA-North

GA USA-South

NY USA-North

N.S. Canada

Ire. UK

Eng. UK

Pru. Europe

PA USA-North

MO USA-South

Han. Europe

Bav. Europe

Den. Europe

NY USA-North

VA USA-South

Ire. UK

PA USA-North

MA USA-North

Pru. Europe

Wur. Europe

NY USA-North

VT USA-North

PA USA-North

NY USA-North

Pru. Europe

VA USA-South

Ire. UK 
Table A-1. continued

\begin{tabular}{|c|c|c|c|c|c|c|}
\hline Name & Race & $\mathbf{M} / \mathbf{S}$ & Age & Occupation & & rth Place \\
\hline Reed, Ogden B. & W & $S$ & 26 & 1st Lt. Co. B 11th & VT. & USA-North \\
\hline Reed, Charles & $\mathrm{W}$ & $S$ & 30 & Private Co. E 11th Inftry & Ire. & UK \\
\hline Reed, William & W & $S$ & 21 & Private Co. B 4th & LA & USA-South \\
\hline Regan, James & W & $\mathrm{S}$ & 30 & Private Co. G 4th & Ire. & UK \\
\hline Regger, Thomas & $\mathrm{W}$ & $S$ & 22 & Private Co. G 4th & $\mathrm{PA}$ & USA-North \\
\hline Reid, James & $\mathrm{W}$ & $S$ & 27 & Private Co. B 11th & Sco. & UK \\
\hline Reilly, Joseph & $\mathrm{W}$ & $\mathbf{S}$ & 22 & Private Co. I 4th & Ire. & UK \\
\hline Reilly, John & $\mathrm{W}$ & $S$ & 23 & Private Co. E 11th Inftry & Ire. & UK \\
\hline Reilly, Michael & W & $S$ & 28 & Private Co. G 4th & Ire. & UK \\
\hline Reinhart, John I. & W & $S$ & 24 & Private Co. B 11th & $\mathrm{MD}$ & USA-South \\
\hline Rendlebrook, Joseph & W & $S$ & 46 & Captain Co. G 4th Cav & Pru. & Europe \\
\hline Reper, Herman & W & $S$ & 29 & Private Co. M 4th & Han. & Europe \\
\hline Reuben, John & W & $S$ & 22 & Private Co. B 4th & PA & USA-North \\
\hline Reynolds, John & W & $S$ & 37 & Private Co. E 11th Inftry & Ire. & UK \\
\hline Reynolds, Michael & W & $S$ & 38 & Private Co. E 11th Inftry & Ire. & UK \\
\hline Riechel, Henry W. & W & $S$ & 22 & Private Co. M 4th & $\mathrm{OH}$ & USA-North \\
\hline Riley, James & W & $S$ & 21 & Private Co. M 4th & Ire. & UK \\
\hline Riley, Thomas & W & $S$ & 25 & Private Co. M 4th & NY & USA-North \\
\hline Robinson, William C. & W & $S$ & 26 & Private Co. G 4th & Eng. & UK \\
\hline Rockwell, Charles S. & W & $S$ & 23 & Private Co. B 4th & NY & USA-North \\
\hline Roland, Henry & W & $S$ & 41 & Sergeant Co E 11th & Pru. & Europe \\
\hline Rooney, Mark & W & $S$ & 23 & Corporal Co. F 4th & $\mathrm{OH}$ & USA-North \\
\hline Ross, Carl & W & $S$ & 26 & L.M. Sergeant 11 th & Eng. & UK \\
\hline Rowheld, John & $\mathrm{W}$ & $S$ & 24 & Private Co. $\mathrm{H} 11$ th & Bav. & Europe \\
\hline Roy, Robert & W & $S$ & 24 & Private Co. B 4th & Eng. & UK \\
\hline Royal, John & W & $S$ & 26 & Private Co. E 11th Inftry & Ire. & UK \\
\hline Rushton, George & W & $S$ & 31 & Private Co. E 4th & $\mathrm{ME}$ & USA-North \\
\hline Russell, John & W & $S$ & 22 & Private Co. I 4th & NY & USA-North \\
\hline Ryan, Patrick & W & $S$ & 22 & Private Co. M 4th & NY & USA-North \\
\hline Sassaman, William & W & $S$ & 21 & Private Co. I 4th & PA & USA-North \\
\hline Schnierepp, John & W & $\mathrm{S}$ & 24 & Private Co. G 4th & Wur. & Europe \\
\hline Schroorner, George & W & $S$ & 24 & Private Co. M 4th & $\mathrm{OH}$ & USA-North \\
\hline Schwartz, Jacob & W & $S$ & 26 & Sergeant Co. G 4th & Wur. & Europe \\
\hline Scott, Patrick & W & $S$ & 36 & 2M Sergeant 4th & Ire. & UK \\
\hline Scott Alexander H. & W & $S$ & 24 & Private Co. M 4th & $\mathrm{OH}$ & USA-North \\
\hline Scott, Thomas E. & W & $S$ & 23 & Private Co. E 4th & LA & USA-South \\
\hline Scudder, William L. & W & $S$ & 25 & Private Co. B 11th & NY & USA-North \\
\hline Seinmetz, William & W & $S$ & 33 & Sergeant Co. G 4th & Bad. & Europe \\
\hline Sendan, Isaac & $\mathrm{W}$ & $S$ & 28 & Private Co. H 11th & NJ & USA-North \\
\hline Sesseman, William & W & $S$ & 21 & Private Co. H 11th & $\mathrm{PA}$ & USA-North \\
\hline
\end{tabular}


Table A-1. continued

\begin{tabular}{|c|c|c|c|c|c|c|}
\hline Name & Race & $\mathbf{M} / \mathbf{S}$ & Age & Occupation & \multicolumn{2}{|c|}{ Birth Place } \\
\hline Shaw, David W. & W & $S$ & 25 & Private Co. B 11th & NY & USA-North \\
\hline Shaw, Matthew & $\mathrm{W}$ & $S$ & 25 & Private Co. G 4th & Fin. & Europe \\
\hline Sheahan, Thomas & W & $S$ & 21 & Private Co. B 4th & Ire. & UK \\
\hline Shehan, Dennis & W & $S$ & 24 & Sergeant 11th & Ire. & UK \\
\hline Shelto, Eugene & $\mathrm{W}$ & $S$ & 26 & Musician 11th & Pru. & Europe \\
\hline Shields, William & W & $S$ & 23 & Private Co. M 4th & Ire. & UK \\
\hline Shipeck, Joseph & W & $S$ & 22 & Musician 11th & Pru. & Europe \\
\hline Shipeck, George & W & $S$ & 26 & Musician 11th & Pru. & Europe \\
\hline Shoemaker, Krank L. & $\mathrm{W}$ & $S$ & 28 & 2nd Lt. Co. G 4th & $\mathrm{PA}$ & USA-North \\
\hline Shules, Herman & W & $S$ & 23 & Private Co. $\mathrm{H} 11$ th & PA & USA-North \\
\hline Simpson, Warner & W & $S$ & 22 & Private Co. E 11th Inftry & NY & USA-North \\
\hline Singelton, William & W & $S$ & 27 & Corporal Co. E 4th Cav & LA & USA-South \\
\hline Smith, James & W & $S$ & 28 & Private Co. I 4th & Eng. & UK \\
\hline Smith, John & W & $S$ & 23 & Private Co. G 4th & MA & USA-North \\
\hline Smith, Charles B. & W & $S$ & 25 & Private Co. B 4th & Swe. & Europe \\
\hline Stafford, Henry L & W & $S$ & 27 & Chief Musician 11th & NY & USA-North \\
\hline Stangler, August & W & $S$ & 19 & Musician 11th & Ita. & Europe \\
\hline Stein, John H & W & $S$ & 28 & Private Co. I 4th & Han. & Europe \\
\hline Stevens, David & $\mathrm{W}$ & $S$ & 32 & Private Co. I 4th & Ire. & UK \\
\hline Stone, Dedrick & W & $S$ & 29 & Musician 11th & Han. & Europe \\
\hline Strunk, Charles & W & $S$ & 33 & Private Co. E 4th & Pru. & Europe \\
\hline Stuart, James H. & W & $S$ & 38 & Sergeant Maj 11th Inftry & MA & USA-North \\
\hline Sullivan, Patrick & $\mathrm{W}$ & $\mathrm{S}$ & 24 & Private Co. I 4th & Ire. & UK \\
\hline Sweeney, Henry & W & $\mathrm{M}$ & 37 & 1st Lt. Unattached & Ire. & UK \\
\hline Taylor, Aaron & W & $S$ & 21 & Private Co. H 11th & $\mathrm{OH}$ & USA-North \\
\hline Taylor, James P. & W & $\mathrm{S}$ & 25 & Private Co. G 4th & $\mathrm{MD}$ & USA-South \\
\hline Therdmeinn, Henry & W & $S$ & 29 & Private Co. E 4th & Fra. & Europe \\
\hline Thompson, Henry & W & $S$ & 27 & Private Co. B 4th & NY & USA-North \\
\hline Thompson John & W & $\mathrm{S}$ & 26 & Corporal Co. B 4th & NY & USA-North \\
\hline Thompson, John & W & $S$ & 28 & Private Co. M 4th & Ire. & UK \\
\hline Thompson, John & W & $S$ & 34 & Private Co. G 4th & ENG. & UK \\
\hline Thurstson, George A. & $\mathrm{W}$ & $\mathrm{M}$ & 31 & 1st Lt. Co. E 4th & NY. & USA-North \\
\hline Tipps, Simon & W & $S$ & 24 & Private Co. H 11th & IN & USA-North \\
\hline Tranb, Fredrick & $\mathrm{W}$ & $S$ & 25 & Private Co. E 4th & Wur. & Europe \\
\hline Tucker, William & W & $S$ & 33 & Private Co. B 4th & Ire. & UK \\
\hline Tuesdale, James & W & $S$ & 33 & Sergeant Co. M 4th & $\mathrm{OH}$ & USA-North \\
\hline Uhl, Joseph & $\mathrm{W}$ & $S$ & 24 & Musician 11th & Pru. & Europe \\
\hline Valiand, John F. & W & $S$ & 41 & Private Co. B 11th & $\mathrm{MD}$ & USA-South \\
\hline Varley, Miles & W & $S$ & 41 & Sergeant Co. E 4th Cav & Ire. & UK \\
\hline Varon, William A. & W & $\mathrm{S}$ & 23 & Private Co. M 4th & PA & USA-North \\
\hline
\end{tabular}


Table A-1. continued

\begin{tabular}{|c|c|c|c|c|c|c|}
\hline Name & Race & $\mathbf{M} / \mathbf{S}$ & Age & Occupation & & irth Place \\
\hline Vericent, Henry & $\mathrm{W}$ & S & 24 & Corporal Co. F 4th & Can. & Canada \\
\hline Vogel, Charles & $\mathrm{W}$ & $S$ & 33 & Musician 11th & Aus. & Europe \\
\hline Vogt, Charles $\mathrm{H}$ & W & $S$ & 25 & Private Co. E 4th & LA & USA-South \\
\hline Volney, Carles P. & $\mathrm{W}$ & $S$ & 27 & Private Co. E 4th & MA & USA-North \\
\hline Wagoner, Richard & $\mathrm{W}$ & $S$ & 22 & Private Co. G 4th & NY & USA-North \\
\hline Waibel, William & $\mathrm{W}$ & $S$ & 30 & Corporal Co. B 11 th & Wur. & Europe \\
\hline Waldeck, Charles & $\mathrm{W}$ & $S$ & 24 & Private Co. B 4th & Pru. & Europe \\
\hline Walsh, John & W & $S$ & 27 & Private Co. B 11th & Ire. & UK \\
\hline Walsh, Thomas & $\mathrm{W}$ & $S$ & 27 & Sergeant Co E 11 th & Ire. & UK \\
\hline Warren, Charles & W & $S$ & 32 & Chief Musician 11th & Bar. & Europe \\
\hline Webb, W.W. & W & $S$ & 32 & Bot Mail Captain 4th & NY & USA-North \\
\hline Weirster, Martin & W & $S$ & 27 & Private Co. E 4th & Pru. & Europe \\
\hline Werth, Louis & $\mathrm{W}$ & $\mathrm{M}$ & 29 & Private Co. G 4th & Wur. & Europe \\
\hline Wexel, Rudolph & $\mathrm{W}$ & $S$ & 39 & Musicians 11 th Infantry & Pru. & Europe \\
\hline Wey, Augustus & $\mathrm{W}$ & $S$ & 23 & Sergeant Co. F 4th & $\mathrm{OH}$ & USA-North \\
\hline Wheelen, William & W & $S$ & 29 & Private Co. I 4th & Ier. & UK \\
\hline White, William & W & $S$ & 25 & Private Co. B 11th & PA & USA-North \\
\hline White, John & $\mathrm{W}$ & $S$ & 26 & Private Co. B 11th & Ire. & UK \\
\hline Whitehouse, William L. & $\mathrm{W}$ & $S$ & 21 & Private Co. I 4th & PA & USA-North \\
\hline Wiggins, Samual & $\mathrm{W}$ & $S$ & 23 & Blacksmith Co. G 4th & $\mathrm{OH}$ & USA-North \\
\hline Wikoff, Charles A & W & $S$ & 33 & Captain Co E 11th Inftry. & PA & USA-North \\
\hline Wile, Charles & W & $S$ & 24 & Musician 11th & Pru. & Europe \\
\hline Williams, Richard & $\mathrm{W}$ & $S$ & 22 & Private Co. B 11th & Ire. & UK \\
\hline Williams, Daniel & W & $S$ & 22 & Private Co. I 4th & Ire. & UK \\
\hline Williams, William L. & W & $S$ & 26 & Private Co. B 4th & Wal. & UK \\
\hline Wilson, Frank & W & $\mathrm{S}$ & 21 & Private Co. B 4th & $\mathrm{OH}$ & USA-North \\
\hline Wilson, Ross D. & $\mathrm{W}$ & $S$ & 19 & Private Co. B 4th & $\mathrm{OH}$ & USA-North \\
\hline Wilson, Charles & W & $S$ & 21 & Private Co. I 4th & Eng. & UK \\
\hline Wilson, William & $\mathrm{W}$ & $\mathrm{S}$ & 24 & Corporal Co. F 4th & PA & USA-North \\
\hline Wing, Fredrick & $\mathrm{W}$ & $S$ & 18 & Private Co. B 4th & $\mathrm{ME}$ & USA-North \\
\hline Wolf, Ad am & $\mathrm{W}$ & S & 28 & Private Co. B 11th & Pru. & Europe \\
\hline Wood, John & W & $S$ & 35 & Private Co. B 4th & Can. & Canada \\
\hline Wotson, William M. & $\mathrm{W}$ & $S$ & 39 & Surgeon US Army & PN & USA-North \\
\hline Zelenke, Joseph & W & $S$ & 30 & Private Co. E 4th & Bov. & Europe \\
\hline
\end{tabular}


Table A-2. 1880 Census Data

\begin{tabular}{|c|c|c|c|c|c|c|}
\hline Name & Race & Age & $\mathbf{M} / \mathbf{S}$ & Occupation & \multicolumn{2}{|c|}{ Birth Place } \\
\hline Alexander, Samual & $\mathrm{B}$ & 31 & & Private & VA & USA-South \\
\hline Alexander, James & $\mathrm{B}$ & 25 & $S$ & Soldier & MS & USA-South \\
\hline Allen, Gilbert & B & 31 & $S$ & Soldier & GA & USA-South \\
\hline Allen, Chris & $\mathrm{B}$ & 23 & $S$ & Soldier & FL & USA-South \\
\hline Anderson, Albert & $\mathrm{B}$ & 34 & $s$ & Soldier & $\mathrm{NC}$ & USA-South \\
\hline Anderson, Peter & $\mathrm{B}$ & 20 & $S$ & Soldier & $\mathrm{TX}$ & USA-South \\
\hline Anderson, Robb & $\mathrm{Ma}$ & 30 & S & Soldier & MO & USA-South \\
\hline Armfield, John & B & 23 & & Private & $\mathrm{NC}$ & USA-South \\
\hline Baird, Chris & $\mathrm{B}$ & 25 & $S$ & Soldier & TN & USA-South \\
\hline Baldwin, Luis & $\mathrm{Ma}$ & 35 & $s$ & Soldier & MS & USA-South \\
\hline Banks, Courtney & $\mathrm{B}$ & 27 & & Sergeant & VA & USA-South \\
\hline Barnes, Samual & B & 38 & $S$ & Soldier & VA & USA-South \\
\hline Bell, J.H. & B & 23 & $S$ & Soldier & $\mathrm{KY}$ & USA-South \\
\hline Benson, Albert & B & 35 & $S$ & Soldier & MS & USA-South \\
\hline Beur, George & B & 21 & $S$ & Soldier & $\mathrm{MD}$ & USA-South \\
\hline Bigsley, John & B & 21 & $S$ & Soldier & $\mathrm{NC}$ & USA-South \\
\hline Bird, Lervis & B & 24 & $S$ & Saddler/Soldier & $\mathrm{GA}$ & USA-South \\
\hline Boyd, Freeland & B & 25 & & Private & $\mathrm{KY}$ & USA-South \\
\hline Brady, Peyton & $\mathrm{B}$ & 27 & $S$ & Soldier & $\mathrm{SC}$ & USA-South \\
\hline Braugh, Joe & B & 19 & $S$ & Soldier & LA & USA-South \\
\hline Brenner, George & W & 40 & $\mathbf{M}$ & Band $M$ aster & Fra & Europe \\
\hline Bright, Daniel & $\mathrm{B}$ & 22 & $S$ & Soldier & PA & USA-North \\
\hline Brown, W.H & $\mathrm{Ma}$ & 24 & $\mathrm{~S}$ & Soldier & IN & USA-North \\
\hline Brown, Galaman & B & 28 & $S$ & Soldier & VA & USA-South \\
\hline Brown, Harris & $\mathrm{Ma}$ & 5 & $S$ & Soldier & $\mathrm{TN}$ & USA-South \\
\hline Brown, Plummer & B & 26 & $S$ & Soldier & $\mathrm{TN}$ & USA-South \\
\hline Brown, Thomas & B & 27 & $S$ & Soldier & IN & USA-North \\
\hline Brunswick, George & $\mathrm{Ma}$ & 34 & $S$ & Soldier & LA & USA-South \\
\hline Burgass, John & $\mathrm{Ma}$ & 24 & & Private & $\mathrm{MD}$ & USA-South \\
\hline Burney, Billy & $\mathrm{B}$ & 23 & $S$ & Soldier & DC & USA-North \\
\hline Burton, Henry & B & 20 & $S$ & Soldier & VA & USA-South \\
\hline Camson, Isaac & $\mathrm{B}$ & 34 & $\mathrm{~S}$ & Soldier & VA & USA-South \\
\hline Canifer, Theofilus & $\mathrm{Ma}$ & 25 & $S$ & Soldier & $\mathrm{MD}$ & USA-South \\
\hline Carr, John & $\mathrm{Ma}$ & 38 & $S$ & Soldier & KY & USA-South \\
\hline Carroll, William H. & B & 23 & & Private & $\mathrm{MD}$ & USA-South \\
\hline Carter, W.H & W & 29 & $S$ & Post Surgion & VA & USA-South \\
\hline Chalman, Joseph & $\mathrm{B}$ & 30 & $S$ & Soldier & $\mathrm{GA}$ & USA-South \\
\hline Chapman, John & B & 30 & $S$ & Soldier & $\mathrm{MD}$ & USA-South \\
\hline Clark, Allen & $\mathrm{Ma}$ & 31 & $S$ & Soldier & $\mathrm{SC}$ & USA-South \\
\hline Clark, John & $\mathrm{Ma}$ & 27 & $S$ & Soldier & VA & USA-South \\
\hline Clark, Joe & $\mathrm{B}$ & 24 & $S$ & Soldier & $\mathrm{NC}$ & USA-South \\
\hline Cockrill, Fremont & B & 27 & & Private & MO & USA-South \\
\hline Cooper, Charles S. & $w$ & 45 & & 1st Lt.. & NY & USA-North \\
\hline Cox, Richard & B & 22 & $s$ & Soldier & KY & USA-South \\
\hline Culbrat, Frank & B & 26 & $S$ & Soldier & VA & USA-South \\
\hline Curtis, Frank & $\mathrm{B}$ & 28 & $S$ & Soldier & VA & USA-South \\
\hline Davis, $\mathrm{Wm}$. & W & 40 & M & Soldier & IN & USA-North \\
\hline
\end{tabular}


Table A-2. continued

\begin{tabular}{|c|c|c|c|c|c|c|}
\hline Name & Race & Age & $\mathbf{M} / \mathbf{S}$ & Occupation & \multicolumn{2}{|c|}{ Birth Place } \\
\hline Davis, Ben & B & 31 & $S$ & Soldier & VA & USA-South \\
\hline Davis, John & $\mathrm{B}$ & 29 & $S$ & Soldier & MO & USA-South \\
\hline Dawcey, Frank & B & 22 & $S$ & Soldier & DC & USA-North \\
\hline Dillon, Joseph & $\mathrm{Ma}$ & 26 & $\mathbf{S}$ & Soldier & $\mathrm{MO}$ & USA-South \\
\hline Dudley, John & B & 29 & M & Soldier & MD & USA-South \\
\hline Duncan, Matthew & B & 31 & $S$ & Soldier & $\mathrm{NC}$ & USA-South \\
\hline Edward, James & B & 30 & $S$ & Soldier & VA & USA-South \\
\hline Eggleston, Millard & W & 25 & & 2nd Lt. & IN & USA-North \\
\hline Elliot, Dirby & $\mathbf{B}$ & 32 & $S$ & Soldier & GA & USA-South \\
\hline English, Josiah & B & 20 & $S$ & Soldier & GA & USA-South \\
\hline Erin, Frank & B & 21 & $S$ & Soldier & $\mathrm{TN}$ & USA-South \\
\hline Farmer, Gusley & $\mathrm{B}$ & 30 & & Private & KY & USA-South \\
\hline Fisher, Chris & B & 23 & $S$ & Soldier & MD & USA-South \\
\hline Floyd, Steve & B & 27 & $S$ & Soldier & VA & USA-South \\
\hline Foster, George & $\mathrm{Ma}$ & 24 & & Private & $\mathrm{TN}$ & USA-South \\
\hline Freeman, $\mathrm{Wm}$. & $\mathrm{Ma}$ & 23 & $S$ & Soldier & NY & USA-North \\
\hline Freeman, Wm., J & $\mathrm{Ma}$ & 25 & $S$ & Soldier & SC & USA-South \\
\hline French, J. W. & W & 36 & M & Soldier & WA & USA-North \\
\hline Galaway, Wm. & MA & 26 & $\mathrm{~S}$ & Soldier & DC & USA-North \\
\hline Garter, Geo. & Ma & 26 & $\mathrm{~S}$ & Soldier & VA & USA-South \\
\hline Gatty, John & B & 24 & $\mathrm{~S}$ & Soldier & KY & USA-South \\
\hline Gay, Emanuel & B & 24 & & Private & GA & USA-South \\
\hline Gray, David & $\mathbf{B}$ & 31 & & Private & WV & USA-South \\
\hline Grayson, Wm. & B & 26 & $\mathrm{~S}$ & Soldier & $\mathrm{GA}$ & USA-South \\
\hline Green, Nathan & B & 27 & & Private & VA & USA-South \\
\hline Green, Frank H. & B & 21 & & Private & Can & Canada \\
\hline Greirson, B. H. & W & 53 & $\mathbf{M}$ & Soldier & PA & USA-North \\
\hline Grenn, Aaron & B & 22 & $S$ & Soldier & $\mathrm{KY}$ & USA-South \\
\hline Grey, George & $\mathrm{B}$ & 31 & & Private & MD & USA-South \\
\hline Guyder, Elijah & B & 29 & $S$ & Soldier & VA & USA-South \\
\hline Haines, Lerv & B & 39 & & Sergeant & PA & USA-North \\
\hline Hall, Benjamin & B & 24 & $S$ & Soldier & MO & USA-South \\
\hline Hall, Henry & $\mathrm{Ma}$ & 27 & $S$ & Soldier & SC & USA-South \\
\hline Hansen, Wm. & $\mathbf{B}$ & 28 & $S$ & Soldier & $\mathrm{KY}$ & USA-South \\
\hline Hardiman, Thr. G & B & 24 & & Private & IN & USA-North \\
\hline Harris, Henry & B & 28 & & Private & $\mathrm{TN}$ & USA-South \\
\hline Harris, Simon & $\mathbf{B}$ & 24 & & Sergeant & $\mathrm{AL}$ & USA-South \\
\hline Harrison, Jeff & B & 18 & $s$ & Soldier & PA & USA-North \\
\hline Hatcher, Richard & B & 23 & $S$ & Soldier & VA & USA-South \\
\hline Hatcher, Archer & B & 22 & $S$ & Soldier & $\mathrm{NC}$ & USA-South \\
\hline Hay wood, James & B & 33 & $S$ & Soldier & $\mathrm{NC}$ & USA-South \\
\hline Hecton, Wiley & Ma & 23 & $S$ & Soldier & GA & USA-South \\
\hline Henderson, Henry & B & 22 & $S$ & Soldier & NJ & USA-North \\
\hline Hester, Jack & Ma & 30 & $S$ & Soldier & TN & USA-South \\
\hline Hill, Ezekial & Ma & 24 & $S$ & Soldier & VA & USA-South \\
\hline Hodges, Chris & W & 33 & $\mathbf{M}$ & Soldier & IN & USA-North \\
\hline Hoffard, Norman & B & 23 & $S$ & Soldier & $\mathrm{MD}$ & USA-South \\
\hline
\end{tabular}


Table A-2. continued

\begin{tabular}{|c|c|c|c|c|c|c|}
\hline Name & Race & Age & $\mathbf{M} / \mathbf{S}$ & Occupation & \multicolumn{2}{|c|}{ Birth Place } \\
\hline Holcomb, Peter & B & 26 & & Private & $\mathrm{TN}$ & USA-South \\
\hline Huffman, Wyatt & B & 28 & $s$ & Soldier & $\mathrm{KY}$ & USA-South \\
\hline Huns, William & $\mathrm{B}$ & 47 & $s$ & Soldier & $\mathrm{DC}$ & USA-North \\
\hline Hunter, James & B & 27 & $S$ & Soldier & $\mathrm{TN}$ & USA-South \\
\hline Jackson James & B & 38 & $s$ & Soldier & VA & USA-South \\
\hline Jackson, Isaac & $\mathbf{B}$ & 27 & $S$ & Soldier & $\mathrm{KY}$ & USA-South \\
\hline Johnson, Chris & $\mathrm{Ma}$ & 22 & $S$ & Soldier & $\mathrm{KY}$ & USA-South \\
\hline Johnson, Chris & B & 26 & $S$ & Soldier & $\mathrm{KY}$ & USA-South \\
\hline Johnson, Henry & B & 24 & $S$ & Soldier & $\mathrm{NC}$ & USA-South \\
\hline Johnson, Richard S. & $\mathrm{Ma}$ & 31 & & Lieut Sergeant & VA & USA-South \\
\hline Johnson, Robert H. & B & 21 & & Private & VA & USA-South \\
\hline Johnson, Sidney & B & 28 & $s$ & Soldier & KY & USA-South \\
\hline Johnson, Walker & B & 22 & & Private & $\mathrm{AR}$ & USA-South \\
\hline Johnson, William & $\mathrm{Ma}$ & 28 & & Private & VA & USA-South \\
\hline Johnson, William & $\mathrm{Ma}$ & 24 & $S$ & Soldier & VA & USA-South \\
\hline Jones, Henry & B & 26 & & Private & MS & USA-South \\
\hline Jones, Philip & B & 33 & & Sergeant & VA & USA-South \\
\hline Jones, Wm. & B & 23 & $S$ & Soldier & TN & USA-South \\
\hline Jones, Wm. & $\mathrm{Ma}$ & 31 & $s$ & Soldier & $\mathrm{MD}$ & USA-South \\
\hline Jordan, John & B & 25 & $S$ & Soldier & $\mathrm{AR}$ & USA-South \\
\hline Jords, Dock & $\mathrm{B}$ & 28 & $S$ & Soldier & VA & USA-South \\
\hline Joseph, Alexander & B & 36 & $S$ & Soldier & $\mathrm{TN}$ & USA-South \\
\hline Kendricks, Luisey & $\mathrm{Ma}$ & 26 & $S$ & Soldier & $\mathrm{KY}$ & USA-South \\
\hline Kennedy, Samual & $\mathrm{Ma}$ & 35 & $S$ & Soldier & KY & USA-South \\
\hline King, Charles & B & 24 & $S$ & Soldier & $\mathrm{MD}$ & USA-South \\
\hline Larkins, James & B & 30 & $S$ & Soldier & $\mathrm{KY}$ & USA-South \\
\hline Law, Jas. H. & W & 26 & $S$ & Soldier & PA & USA-North \\
\hline Lee, P.L. & W & 42 & $S$ & Soldier & VA & USA-South \\
\hline Lee, Joel & B & 24 & & Private & GA & USA-South \\
\hline Lee, John & Ma & 26 & $S$ & Soldier & Cub & Cuba \\
\hline Lenard, Sam & $\mathrm{Ma}$ & 34 & $S$ & Soldier & NY & USA-North \\
\hline Lewis, John & B & 32 & $\mathrm{~S}$ & Soldier & VA & USA-South \\
\hline London, Julius & B & 25 & $S$ & Soldier & $\mathrm{GA}$ & USA-South \\
\hline Louis, Hill & $\mathrm{Ma}$ & 34 & $S$ & Soldier & $\mathrm{MD}$ & USA-South \\
\hline Lowlace, Scott & $\mathrm{Ma}$ & 26 & $S$ & Soldier & $\mathrm{TN}$ & USA-South \\
\hline Martin, Isaac J. & $\mathrm{Ma}$ & 25 & & Private & $\mathrm{AL}$ & USA-South \\
\hline Mason, Thos. & $\mathrm{B}$ & 30 & $S$ & Soldier & GA & USA-South \\
\hline Matthews, Samual & $\mathrm{Ma}$ & 26 & $S$ & Soldier & WA & USA-North \\
\hline McElroy, John & $\mathbf{B}$ & 22 & $S$ & Soldier & $\mathrm{KY}$ & USA-South \\
\hline McKenney, Jerry & $\mathrm{Ma}$ & 24 & & Private & $\mathrm{KY}$ & USA-South \\
\hline McWilliams, Geo. & $\mathrm{B}$ & 32 & $S$ & Soldier & $\mathrm{KY}$ & USA-South \\
\hline Miller, Hazzand & B & 38 & $S$ & Soldier & PA & USA-North \\
\hline Millspaugh, J. L. & W & 35 & M & Post Trader & NY & USA-North \\
\hline Mitchell, Fred & $\mathrm{Ma}$ & 23 & $\mathrm{~S}$ & Soldier & VA & USA-South \\
\hline Moon, Thos., B & B & 21 & $\mathrm{~S}$ & Soldier & $\mathrm{TN}$ & USA-South \\
\hline Moore, Henry & $\mathrm{B}$ & 28 & $S$ & Soldier & $\mathrm{NJ}$ & USA-North \\
\hline Moral, Ben & $\mathrm{B}$ & 33 & $S$ & Soldier & LA & USA-South \\
\hline
\end{tabular}


Table A-2. continued

\begin{tabular}{|c|c|c|c|c|c|c|}
\hline Name & Race & Age & $\mathbf{M} / \mathbf{S}$ & Occu pation & \multicolumn{2}{|c|}{ Birth Place } \\
\hline Mosley, Zackariah & $\mathrm{B}$ & 33 & & Trumpeter & PA & USA-North \\
\hline Moss, Alfred & $\mathrm{Ma}$ & 25 & $S$ & Soldier & VA & USA-South \\
\hline Mulford, Benny & Ma & 27 & $S$ & Soldier & $\mathrm{CT}$ & USA-North \\
\hline Nelson, John & $\mathrm{B}$ & 24 & & Private & VA & USA-South \\
\hline Newman, Albert & B & 25 & $S$ & Soldier & VA & USA-South \\
\hline Nick, Calvin & Ma & 32 & $S$ & Soldier & $\mathrm{TN}$ & USA-South \\
\hline Norton, John & Ma & 21 & $S$ & Soldier & VA & USA-South \\
\hline Norvell, Stevene T. & W & 45 & & Captain & MI & USA-North \\
\hline Offias, Alexander & B & 22 & $S$ & Soldier & VA & USA-South \\
\hline Orvus, Henry & B & 19 & $S$ & Soldier & $\mathrm{TX}$ & USA-South \\
\hline Parker, Chris & B & 27 & $S$ & Soldier & KY & USA-South \\
\hline Parker, Joseph & $\mathrm{Ma}$ & 42 & $S$ & Soldier & $\mathrm{TN}$ & USA-South \\
\hline Parrats, Martin & B & 25 & & Private & VA & USA-South \\
\hline Pereon, Squire & B & 24 & $S$ & Soldier & $\mathrm{MD}$ & USA-South \\
\hline Perry, Henry & $\mathrm{Ma}$ & 28 & $S$ & Soldier & MD & USA-South \\
\hline Petitt, Charles & $\mathbf{B}$ & 22 & & Private & VA & USA-South \\
\hline Pevoy, Frank & B & 27 & $S$ & Soldier & VA & USA-South \\
\hline Pillar, Alaxander & $\mathrm{Ma}$ & 28 & $S$ & Soldier & $\mathrm{TN}$ & USA-South \\
\hline Pillett, Wm. & B & 35 & $S$ & Soldier & KY & USA-South \\
\hline Plato, Ceats & B & 40 & $S$ & Soldier & MD & USA-South \\
\hline Pointer, Clay & $\mathrm{Ma}$ & 26 & $S$ & Soldier & $\mathrm{KY}$ & USA-South \\
\hline Powell, Solomon & $\mathrm{Ma}$ & 31 & $S$ & Soldier & VA & USA-South \\
\hline Powell, W.A & $\mathrm{Ma}$ & 30 & $S$ & Soldier & $\mathrm{KY}$ & USA-South \\
\hline Pratt, Richard & B & 29 & $S$ & Soldier & $\mathrm{OH}$ & USA-North \\
\hline Pursell, Ed & $\mathrm{Ma}$ & 23 & $S$ & Soldier & VA & USA-South \\
\hline Raines, William & B & 25 & & Private & $\mathrm{TN}$ & USA-South \\
\hline Reed, Wm. & B & 28 & $\mathrm{~S}$ & Soldier & GA & USA-South \\
\hline Ringold, John & B & 23 & $S$ & Soldier & $\mathrm{DC}$ & USA-North \\
\hline Roach, William & B & 32 & $S$ & Soldier & DC & USA-North \\
\hline Robb, Stephen & $\mathrm{Ma}$ & 23 & $\mathrm{~S}$ & Soldier & $\mathrm{TN}$ & USA-South \\
\hline Robb, Stephen & B & 28 & & Private & TN & USA-South \\
\hline Robbins, John & B & 32 & $s$ & Soldier & AL & USA-South \\
\hline Robinson, Phillip & B & 30 & $S$ & Soldier & VA & USA-South \\
\hline Robinson, John & B & 23 & $S$ & Soldier & VA & USA-South \\
\hline Rose, William & B & 24 & & Private & GA & USA-South \\
\hline Ross, Hallon & $\mathrm{B}$ & 21 & $S$ & Soldier & $\mathrm{KY}$ & USA-South \\
\hline Ruddle, John & Ma & 29 & & Private & $\mathrm{KY}$ & USA-South \\
\hline Satchell, Samual & $\mathrm{Ma}$ & 24 & & Private & VA & USA-South \\
\hline Scott, Winfield & B & 32 & & Black Smith & PA & USA-North \\
\hline Scott, Charles & B & 21 & & Private & VA & USA-South \\
\hline Scott, John R. & B & 29 & & Private & $\mathrm{TN}$ & USA-South \\
\hline Shankling, Willard & B & 31 & & Coporal & PA & USA-North \\
\hline Shaw, Perry & B & 24 & & Private & GA & USA-South \\
\hline Shaw, Perry & B & 22 & $S$ & Soldier & VA & USA-South \\
\hline Shorpshire, Shelvin & B & 33 & $S$ & Soldier & $\mathrm{AL}$ & USA-South \\
\hline Simmons, Manon & B & 23 & $S$ & Soldier & $\mathrm{GA}$ & USA-South \\
\hline Simpson, Ambro & B & 27 & $S$ & Soldier & $\mathrm{FL}$ & USA-South \\
\hline
\end{tabular}


Table A-2. continued

\begin{tabular}{|c|c|c|c|c|c|c|}
\hline Name & Race & Age & $\mathbf{M} / \mathbf{S}$ & Occupation & \multicolumn{2}{|c|}{ Birth Place } \\
\hline Slack, John & $\mathrm{B}$ & 24 & & Private & GA & USA-South \\
\hline Slerash, Cleos & $\mathrm{Ma}$ & 22 & $S$ & Soldier & VA & USA-South \\
\hline Smith, John & $\mathrm{B}$ & 29 & $S$ & Soldier & NY & USA-North \\
\hline Smith, S.S.S. & W & 35 & $S$ & Post Physician & $\mathrm{IN}$ & USA-North \\
\hline Smithers, Robt. & W & 33 & M & Soldier & $\mathrm{IN}$ & USA-North \\
\hline Sommers, Harry & B & 37 & & Coporal & $\mathrm{NY}$ & USA-North \\
\hline Spowden, James & B & 32 & & Private & $\mathrm{PA}$ & USA-North \\
\hline Stevens, Samual & B & 24 & $S$ & Soldier & IL & USA-North \\
\hline Stevenson, Daniel & B & 22 & $S$ & Soldier & GA & USA-South \\
\hline Steward, Jeaih & $\mathrm{Ma}$ & 35 & $S$ & Farrier/Soldier & $\mathrm{MD}$ & USA-South \\
\hline Steward, Edward & $\mathrm{Ma}$ & 24 & & Private & $\mathrm{KY}$ & USA-South \\
\hline Tate, Walter & B & 22 & & Private & VA & USA-South \\
\hline Taylor, Geo. & B & 36 & $S$ & Soldier & $\mathrm{KY}$ & USA-South \\
\hline Taylor, King & B & 24 & & Private & $\mathrm{KY}$ & USA-South \\
\hline Tear, Wallace & W & 39 & W & Soldier & $\mathrm{OH}$ & USA-North \\
\hline Thomas, Henry & B & 24 & $S$ & Soldier & MD & USA-South \\
\hline Thomas, James & $\mathrm{Ma}$ & 30 & $\mathbf{M}$ & Soldier & MO & USA-South \\
\hline Thompson, Thomas & B & 21 & & Private & $\mathrm{KY}$ & USA-South \\
\hline Thompson, Wm. H. & $\mathrm{Ma}$ & 24 & & Coporal & $\mathrm{MD}$ & USA-South \\
\hline Thomson, Isaac & B & 28 & $S$ & Soldier & $\mathrm{PA}$ & USA-North \\
\hline Thornton, Doctor & B & 29 & $S$ & Soldier & GA & USA-South \\
\hline Thrasher, George & B & 24 & & Private & GA & USA-South \\
\hline Tony, Henry & B & 29 & $S$ & Soldier & KY & USA-South \\
\hline Tucker, Allen & $\mathrm{B}$ & 23 & $S$ & Soldier & VA & USA-South \\
\hline Tucker, George C. & $\mathrm{Ma}$ & 29 & & Trumpeter & $\mathrm{KY}$ & USA-South \\
\hline Turner, George & B & 22 & & Private & $\mathrm{MD}$ & USA-South \\
\hline Tyler, James H. & B & 29 & & Coporal & VA & USA-South \\
\hline Walker, Horace & $\mathrm{B}$ & 25 & & Private & $\mathrm{VA}$ & USA-South \\
\hline Wallick, Andrew & w & 38 & $S$ & Post Saddler & Ger & Europe \\
\hline Walters, Smith & B & 33 & & Private & VA & USA-South \\
\hline Ward, Wm. P & B & 26 & $S$ & Soldier & $\mathrm{MD}$ & USA-South \\
\hline Washington, George & B & 30 & $S$ & Soldier & PA & USA-North \\
\hline Watte, John & B & 25 & & Private & VA & USA-South \\
\hline Whidder, Samuel & B & 29 & $S$ & Soldier & VA & USA-South \\
\hline White, Aurther & B & 26 & S & Soldier & MO & USA-South \\
\hline White, Thomas & B & 33 & & Sergeant & $\mathrm{MD}$ & USA-South \\
\hline Whitney, Wm. & $\mathrm{B}$ & 31 & $S$ & Soldier & $\mathrm{DC}$ & USA-North \\
\hline Wickmire, Peter & B & 28 & & Private & $\mathrm{TN}$ & USA-South \\
\hline Wiggins, John & B & 30 & $S$ & Soldier & VA & USA-South \\
\hline William, H.R & $\mathrm{Ma}$ & 36 & $S$ & Soldier & $\mathrm{OH}$ & USA-North \\
\hline Williams, Charles & B & 24 & & Private & $\mathrm{GA}$ & USA-South \\
\hline Williams, Frisky & B & 21 & & Private & $\mathrm{MD}$ & USA-South \\
\hline Williams, George & $\mathrm{Ma}$ & 26 & $\mathrm{~S}$ & Soldier & TN & USA-South \\
\hline Williams, James & $\mathrm{Ma}$ & 27 & $S$ & Soldier & Peru & South America \\
\hline Williams, Samual & $\mathrm{Ma}$ & 33 & $S$ & Soldier & VA & USA-South \\
\hline Williams, Wash & B & 24 & & Private & MS & USA-South \\
\hline Willis, William & B & 24 & & Private & AL & USA-South \\
\hline
\end{tabular}


Table A-2. continued

\begin{tabular}{lccccccc}
\multicolumn{1}{c}{ Name } & Race & Age & M/S & Occupation & \multicolumn{2}{c}{ Birth Place } \\
Wilson, James & Ma & 31 & S & Soldier & NC & USA-South \\
Winston, Jordan & B & 25 & S & Soldier & MS & USA-South \\
Woolford, Charles E. & B & 25 & & Private & MD & USA-South \\
Worten, Sanders & B & 31 & S & Soldier & VA & USA-South \\
Wren, Peter & B & 28 & S & Soldier & MD & USA-South \\
Wyatt, John W. & B & 29 & & Private & VA & USA-South
\end{tabular}


Table B-1. Artifact Data

\begin{tabular}{|c|c|c|c|c|c|c|c|c|c|c|c|c|}
\hline $\begin{array}{l}\dot{0} \\
\sum_{00} \\
\text { g }\end{array}$ & 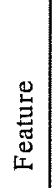 & 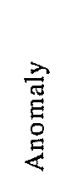 & 菅 & 焏 & $\begin{array}{l}\text { 咅 } \\
\stackrel{\Delta}{0}\end{array}$ & 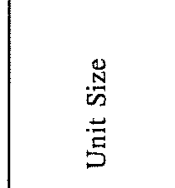 & 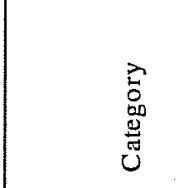 & 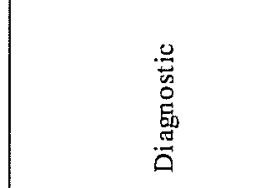 & 至 & 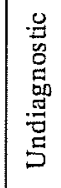 & 覃 & 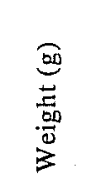 \\
\hline 1 & & & 1 & 1 & $0-6^{\prime \prime}$ & $20 \times 20$ inch & Lithics & Flake & & 1 & 1 & 1.10 \\
\hline 2 & & & 2 & 1 & $0-6 "$ & $20 \times 20$ inch & Lithics & Chert & & 1 & 1 & 38.30 \\
\hline 3 & & & 3 & 1 & $0-6^{\prime \prime}$ & $20 \times 20$ inch & Lithics & Chert & & 3 & 3 & 9.80 \\
\hline 4 & & & 4 & 1 & $0-6 "$ & $20 \times 20$ inch & Faunal & Bone, Bovinae & 1 & & 1 & 2.49 \\
\hline 5 & & & 5 & 1 & $0-6^{\prime \prime}$ & $20 \times 20$ inch & Lithics & Flake & & 1 & 1 & 5.80 \\
\hline 6 & & & 6 & 1 & $0-6 "$ & $20 \times 20$ inch & Lithics & Flake & & 1 & 1 & 2.90 \\
\hline 7 & & & 7 & 1 & $0-6 "$ & $20 \times 20$ inch & Construction & Cut nail & & 1 & 1 & 1.50 \\
\hline 7 & & & 7 & 1 & $0-6^{\prime \prime}$ & $20 \times 20$ inch & Lithics & Flake & & 1 & 1 & 1.00 \\
\hline 10 & & & 10 & 1 & $0-6^{\prime \prime}$ & $20 \times 20$ inch & Lithics & Flake & & 1 & 1 & 8.20 \\
\hline 13 & & & 13 & 1 & $0-6 "$ & $20 \times 20$ inch & Lithics & Flake & & 2 & 2 & 17.00 \\
\hline 15 & & & 15 & 1 & $0-6^{\prime \prime}$ & $20 \times 20$ inch & Lithics & Flake & & 3 & 3 & 4.80 \\
\hline 15 & & & 15 & 1 & $0-6^{\prime \prime}$ & $20 \times 20$ inch & Miscellaneous & Metal frag & & 1 & 1 & 2.20 \\
\hline 17 & & & 17 & 1 & $0-6^{\prime \prime}$ & $20 \times 20$ inch & Lithics & Flake & & 2 & 2 & 1.80 \\
\hline 18 & & & 18 & 1 & $0-6^{\prime \prime}$ & $20 \times 20$ inch & Domestic & Bottle glass, clear & & 1 & 1 & 0.30 \\
\hline 18 & & & 18 & 1 & $0-6^{\prime \prime}$ & $20 \times 20$ inch & Lithics & Chert & & 1 & 1 & 5.50 \\
\hline 18 & & & 18 & 1 & $0-6^{\prime \prime}$ & $20 \times 20$ inch & Lithics & Flake & & 1 & 1 & 0.20 \\
\hline 18 & & & 18 & 1 & $0-6^{\prime \prime}$ & $20 \times 20$ inch & Lithics & Flake & & 1 & 1 & 0.10 \\
\hline 19 & & & 19 & 1 & $0-6^{\prime \prime}$ & $20 \times 20$ inch & Lithics & Flake & & 2 & 2 & 2.50 \\
\hline 20 & & & 20 & 1 & $0-6^{\prime \prime}$ & $20 \times 20$ inch & Lithics & Flake & & 1 & 1 & 3.30 \\
\hline 25 & & & 25 & 1 & $0-6^{\prime \prime}$ & $20 \times 20$ inch & Lithics & Flake & & 1 & 1 & 0.60 \\
\hline 26 & & & 26 & 1 & $0-6 "$ & $20 \times 20$ inch & Domestic & Bottle glass, aqua & & 1 & 1 & 0.20 \\
\hline 29 & & & 29 & 1 & $0-6^{\prime \prime}$ & $20 \times 20$ inch & Lithics & Flake & & 1 & 1 & 5.40 \\
\hline 30 & & & 30 & 1 & $0-6^{\prime \prime}$ & $20 \times 20$ inch & Domestic & Whiteware, undec. & & 1 & 1 & 1.80 \\
\hline 33 & & & 33 & 1 & $0-6^{\prime \prime}$ & $20 \times 20$ inch & Domestic & Bottle glass, green & & 10 & 10 & 18.80 \\
\hline 34 & & & 34 & 1 & $0-6^{\prime \prime}$ & $20 \times 20$ inch & Personal & Button, Metal & 1 & & 1 & \\
\hline 36 & & & 36 & 1 & $0-6^{\prime \prime}$ & $20 \times 20$ inch & Lithics & Chert & & 1 & 1 & 37.20 \\
\hline 45 & & & 45 & 1 & $0-6^{\prime \prime}$ & $20 \times 20$ inch & Domestic & Bottle glass, clear & & 1 & 1 & 0.10 \\
\hline 47 & & & 47 & 1 & $0-6^{\prime \prime}$ & $20 \times 20$ inch & Construction & Cut nail & & 2 & 2 & 3.80 \\
\hline 47 & & & 47 & 1 & $0-6^{\prime \prime}$ & $20 \times 20$ inch & Lithics & Flake & & 2 & 2 & 2.60 \\
\hline 48 & & & 48 & 1 & $0-6^{\prime \prime}$ & $20 \times 20$ inch & Domestic & Bottle glass, green & & 1 & 1 & 5.20 \\
\hline 48 & & & 48 & 1 & $0-6^{\prime \prime}$ & $20 \times 20$ inch & Personal & Button, Metal & 1 & & 1 & \\
\hline 49 & & & 49 & 1 & $0-6^{\prime \prime}$ & $20 \times 20$ inch & Domestic & Bottle glass, brown & & 1 & 1 & 3.20 \\
\hline 50 & & & 50 & 1 & $0-6^{\prime \prime}$ & $20 \times 20$ inch & Construction & Cut nail & 1 & 1 & 2 & 7.50 \\
\hline 52 & & & 52 & 1 & $0-6^{\prime \prime}$ & $20 \times 20$ inch & Lithics & Flake & & 1 & 1 & 3.20 \\
\hline 54 & & & 54 & 1 & $0-6^{n}$ & $20 \times 20$ inch & Construction & Cut nail & 9 & & 9 & 26.50 \\
\hline 54 & & & 54 & 1 & $0-6^{\prime \prime}$ & $20 \times 20$ inch & \begin{tabular}{|l|} 
Domestic \\
\end{tabular} & Vessel glass, clear & & 3 & 3 & 42.50 \\
\hline 54 & & & 54 & 1 & $0-6^{\prime \prime}$ & $20 \times 20$ inch & Miscellaneous & Charcoal & & & 0 & 0.70 \\
\hline 55 & & & 55 & 1 & $0-6^{\prime \prime}$ & $20 \times 20$ inch & Domestic & Bottle glass, brown & & 6 & 6 & 12.50 \\
\hline
\end{tabular}


Table B-1. continued

\begin{tabular}{|c|c|c|c|c|c|c|c|c|c|c|c|c|}
\hline $\begin{array}{l}\dot{0} \\
\dot{z}_{g} \\
\dot{g} \\
\dot{m}\end{array}$ & 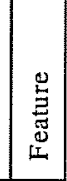 & $\begin{array}{l}\text { 齐 } \\
\text { 戛 } \\
\text { 是 }\end{array}$ & 泀 & $\begin{array}{l}\overrightarrow{0} \\
\vec{J}\end{array}$ & $\begin{array}{l}\text { 咅 } \\
\text { 口 }\end{array}$ & 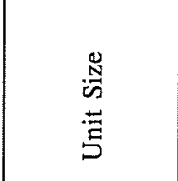 & 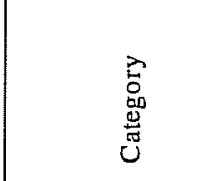 & 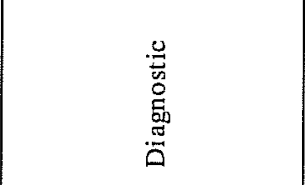 & $\underset{\mathrm{E}}{\mathrm{E}}$ & 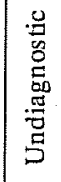 & $\begin{array}{l}\text { 丞 } \\
\stackrel{2}{\circ}\end{array}$ & 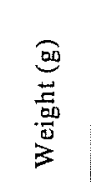 \\
\hline 58 & & & 58 & 1 & $0-6^{\prime \prime}$ & $20 \times 20$ inch & Construction & Cut nail & 2 & & 2 & 6.20 \\
\hline 59 & & & 59 & 1 & $0-6^{\prime \prime}$ & $20 \times 20$ inch & Miscellaneous & Metal frag & & 1 & 1 & 1.20 \\
\hline 60 & & & 60 & 1 & $0-6 "$ & $20 \times 20$ inch & Construction & Cut nail & & 1 & 1 & 0.60 \\
\hline 60 & & & 60 & 1 & $0-6^{\prime \prime}$ & $20 \times 20$ inch & Faunal & Mammal & & 1 & 1 & 0.14 \\
\hline 60 & & & 60 & 1 & $0-6 "$ & $20 \times 20$ inch & Lithics & Flake & & 2 & 2 & 2.00 \\
\hline 60 & & & 60 & 1 & $0-6 "$ & $20 \times 20$ inch & Miscellaneous & Charcoal & & & 0 & 0.50 \\
\hline 60 & & & 60 & 1 & $0-6 "$ & $20 \times 20$ inch & Miscellaneous & Metal frag & & 2 & 2 & 0.70 \\
\hline 60 & & & 60 & 1 & $0-6 "$ & $20 \times 20$ inch & Miscellaneous & Mussel shell & & 1 & 1 & 0.10 \\
\hline 60 & & & 60 & 1 & $0-6^{\prime \prime}$ & $20 \times 20$ inch & Miscellaneous & Mussel shell & & 1 & 1 & 1.00 \\
\hline 70 & & & 70 & 1 & $0-6 "$ & $20 \times 20$ inch & Domestic & Bottle glass, brown & & 1 & 1 & 0.30 \\
\hline 70 & & & 70 & 1 & $0-6 "$ & $20 \times 20$ inch & Miscellaneous & Mussel shell & & 1 & 1 & 0.70 \\
\hline 71 & & & 71 & 1 & $0-6 "$ & $20 \times 20$ inch & Domestic & Bottle glass, aqua & 3 & & 3 & 8.60 \\
\hline 72 & & & 72 & 1 & $0-6 "$ & $20 \times 20$ inch & Construction & Cut nail & 1 & & 1 & 2.30 \\
\hline 72 & & & 72 & 1 & $0-6^{\prime \prime}$ & $20 \times 20$ inch & Workshop & Horseshoe nail & 1 & & 1 & 5.20 \\
\hline 73 & $\mathrm{~F}-1$ & & 73 & 1 & $0-12 "$ & $20 \times 20$ inch & Construction & Cut nail & & 3 & 3 & 4.00 \\
\hline 73 & $\mathrm{~F}-1$ & & 73 & 1 & $0-12 "$ & $20 \times 20$ inch & Construction & Cut nail & 2 & 2 & 4 & 8.60 \\
\hline 73 & $F-1$ & & 73 & 1 & $0-12 "$ & $20 \times 20$ inch & Construction & Cut nail & 2 & & 2 & 6.00 \\
\hline 73 & $\mathrm{~F}-1$ & & 73 & 1 & $0-12 "$ & $20 \times 20$ inch & Domestic & Bottle glass, brown & 1 & 2 & 3 & 16.00 \\
\hline 73 & $\mathrm{~F}-1$ & & 73 & 1 & $0-12 "$ & $20 \times 20$ inch & Domestic & Bottle glass, brown & & 12 & 12 & 54.80 \\
\hline 73 & F-1 & & 73 & 1 & $0-12^{\prime \prime}$ & $20 \times 20$ inch & Domestic & Bottle glass, brown & & 1 & 1 & 3.50 \\
\hline 73 & $\mathrm{~F}-1$ & & 73 & 1 & $0-12^{\prime \prime}$ & $20 \times 20$ inch & Domestic & Bottle glass, brown & & 1 & 1 & 1.30 \\
\hline 73 & F-1 & & 73 & 1 & $0-6^{\prime \prime}$ & $20 \times 20$ inch & Domestic & Bottle glass, clear & & 1 & 1 & 1.20 \\
\hline 73 & F-1 & & 73 & 1 & $0-12^{\prime \prime}$ & $20 \times 20$ inch & Domestic & Bottle, brown & 1 & & 1 & \\
\hline 73 & $\mathrm{~F}-1$ & & 73 & 1 & $0-12^{\prime \prime}$ & $20 \times 20$ inch & Faunal & Bone, Meliagris gallap. & 2 & & 2 & 8.24 \\
\hline 73 & $\mathrm{~F}-1$ & & 73 & 1 & $0-12^{\prime \prime}$ & $20 \times 20$ inch & Faunal & Bone, Mammal & & 16 & 16 & 4.33 \\
\hline 73 & $\mathrm{~F}-1$ & & 73 & 1 & $0-12^{\prime \prime}$ & $20 \times 20$ inch & Faunal & Bone, Bovinae & 1 & & 1 & 38.45 \\
\hline 73 & $\mathrm{~F}-1$ & & 73 & 1 & $0-12^{\prime \prime}$ & $20 \times 20$ inch & Miscellaneous & Burnt soil, clod & & 1 & 1 & 1.70 \\
\hline 73 & $\mathrm{~F}-1$ & & 73 & 1 & $0-12 "$ & $20 \times 20$ inch & Miscellaneous & Charcoal & & & 0 & 0.70 \\
\hline 73 & $F-1$ & & 73 & 1 & $0-12^{\prime \prime}$ & $20 \times 20$ inch & Miscellaneous & Charcoal & & & 0 & 0.10 \\
\hline 73 & $\mathrm{~F}-1$ & & 73 & 1 & $0-12^{\prime \prime}$ & $20 \times 20$ inch & Miscellaneous & Charcoal & & & 0 & 4.00 \\
\hline 73 & $\mathrm{~F}-1$ & & 73 & 1 & $0-12^{\prime \prime}$ & $20 \times 20$ inch & Miscellaneous & Charcoal & & & 0 & 2.10 \\
\hline 73 & $\mathrm{~F}-1$ & & 73 & 1 & $0-12^{\prime \prime}$ & $20 \times 20$ inch & Miscellaneous & Metal frag & & 4 & 4 & 7.70 \\
\hline 73 & $\mathrm{~F}-1$ & & 73 & 1 & $0-12 "$ & $20 \times 20$ inch & Miscellaneous & Metal frag & & 1 & 1 & 3.20 \\
\hline 73 & $\mathrm{~F}-1$ & & 73 & 1 & $0-12 "$ & $20 \times 20$ inch & Miscellaneous & Metal frag & & 11 & 11 & 22.80 \\
\hline 73 & F-1 & & 73 & 1 & $0-12 "$ & $20 \times 20$ inch & Miscellaneous & Metal frag & & 32 & 32 & 63.80 \\
\hline 73 & $F-1$ & & 73 & 1 & $0-12 "$ & $20 \times 20$ inch & Miscellaneous & Metal frag & & 4 & 4 & 10.20 \\
\hline 73 & $\mathrm{~F}-1$ & & 73 & 1 & $0-12^{\prime \prime}$ & $20 \times 20$ inch & Workshop & Horseshoe nail & 1 & & 1 & 2.70 \\
\hline 73 & $\mathrm{~F}-1$ & & 73 & 1 & $0-12 "$ & $20 \times 20$ inch & Workshop & Horseshoe nail & & 1 & 1 & 2.00 \\
\hline 73 & $\mathrm{~F}-1$ & & 73 & 1 & $0-12^{n}$ & $20 \times 20$ inch & Workshop & Horseshoe nail & 1 & & 1 & 4.00 \\
\hline 73 & $F-1$ & & 73 & 1 & $0-12 "$ & $20 \times 20$ inch & Workshop & Horseshoe nail & 2 & 2 & 4 & 12.00 \\
\hline 73 & $F-1$ & & 73 & 1 & $0-12 "$ & $20 \times 20$ inch & Workshop & Me tal strap & & 1 & 1 & 7.70 \\
\hline 74 & $F-1$ & & 74 & 1 & $0-12 "$ & $20 \times 20$ inch & Workshop & Slag nodule & & 1 & 1 & 4.40 \\
\hline 74 & $|F-1|$ & & 74 & 1 & $0-6^{\prime \prime}$ & $20 \times 20$ inch & Construction & Cut nail & & 1 & 1 & 4.00 \\
\hline
\end{tabular}


Table B-1. continued

\begin{tabular}{|c|c|c|c|c|c|c|c|c|c|c|c|c|}
\hline 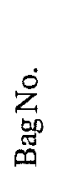 & 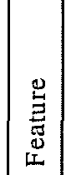 & 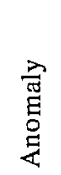 & $\overrightarrow{\vec{E}}$ & 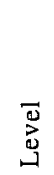 & $\begin{array}{l}\text { 吉 } \\
\text { 口̆ }\end{array}$ & 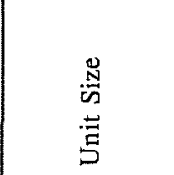 & 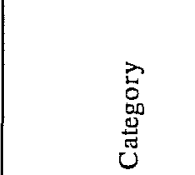 & 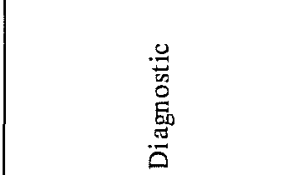 & 莺 & 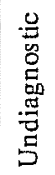 & $\begin{array}{l}\text { ज्ञّ } \\
0 \\
\end{array}$ & 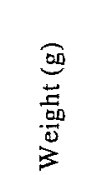 \\
\hline 74 & $\mathrm{~F}-1$ & & 74 & 1 & $0-6^{\prime \prime}$ & $20 \times 20$ inch & Construction & Cut nail & & 2 & 2 & 2.50 \\
\hline 74 & $\mathrm{~F}-1$ & & 74 & 1 & $0-6 "$ & $20 \times 20$ inch & Construction & Cut nail & & 2 & 2 & 2.40 \\
\hline 74 & $\mathrm{~F}-1$ & & 74 & 1 & $0-6 "$ & $20 \times 20$ inch & Domestic & Bottle glass, aqua & & 1 & 1 & 0.20 \\
\hline 74 & $F-1$ & & 74 & 1 & $0-6^{\prime \prime}$ & $20 \times 20$ inch & Domestic & Bottle glass, brown & & 4 & 4 & 1.40 \\
\hline 74 & $\mathrm{~F}-1$ & & 74 & 1 & $0-6^{\prime \prime}$ & $20 \times 20$ inch & Domestic & Bottle glass, brown & & 1 & 1 & 0.10 \\
\hline 74 & $\mathrm{~F}-1$ & & 74 & 1 & $0-6^{\prime \prime}$ & $20 \times 20$ inch & Miscellaneous & Charcoal & & & 0 & 0.10 \\
\hline 74 & $\mathrm{~F}-1$ & & 74 & 1 & $0-6^{\prime \prime}$ & $20 \times 20$ inch & Miscellaneous & Charcoal & & & 0 & 0.60 \\
\hline 74 & $F-1$ & & 74 & 1 & $0-6 "$ & $20 \times 20$ inch & Miscellaneous & Metal frag & & 2 & 2 & 1.50 \\
\hline 74 & $\mathrm{~F}-1$ & & 74 & 1 & $0-6^{\prime \prime}$ & $20 \times 20$ inch & Workshop & Horseshoe nail & & 2 & 2 & 3.90 \\
\hline 74 & $\mathrm{~F}-1$ & & 74 & 1 & $0-6 "$ & $20 \times 20$ inch & Workshop & Horseshoe nail & 1 & & 1 & 3.70 \\
\hline 74 & $\mathrm{~F}-1$ & & 74 & 1 & $0-6^{\prime \prime}$ & $20 \times 20$ inch & Workshop & Horseshoe nail & 2 & 19 & 21 & 26.50 \\
\hline 74 & $\mathrm{~F}-1$ & & 74 & 1 & $0-6 "$ & $20 \times 20$ inch & Workshop & Iron cutting & & 1 & 1 & 40.80 \\
\hline 75 & $\mathrm{~F}-1$ & & 75 & 1 & $0-6 "$ & $20 \times 20$ inch & Workshop & Iron cutting & & 4 & 4 & 38.70 \\
\hline 75 & $\mathrm{~F}-1$ & & 75 & 1 & $0-6 "$ & $20 \times 20$ inch & Miscellaneous & Metal frag & & 7 & 7 & 3.00 \\
\hline 75 & $\mathrm{~F}-1$ & & 75 & 1 & $0-6^{\prime \prime}$ & $20 \times 20$ inch & Miscellaneous & Mussel shell & & 1 & 1 & 0.20 \\
\hline 76 & $\mathrm{~F}-1$ & & 76 & 1 & $0-6 "$ & $20 \times 20$ inch & Workshop & Hors eshoe nail & & 7 & 7 & 10.50 \\
\hline 76 & $\mathrm{~F}-1$ & & 76 & 1 & $0-6 "$ & $20 \times 20$ inch & Construction & Fencing staple & 1 & & 1 & 5.30 \\
\hline 80 & $F-1$ & & 77 & 1 & $0-10^{\prime \prime}$ & $20 \times 20$ inch & Workshop & Horseshoe nail & 3 & & 3 & 13.30 \\
\hline 80 & $F-1$ & & 77 & 1 & $0-6 "$ & $3 \times 4 \mathrm{ft}$ & Construction & Cut nail & 1 & & 1 & 5.00 \\
\hline 80 & $F-1$ & & 77 & 1 & $0-6^{\prime \prime}$ & $3 \times 4 \mathrm{ft}$ & Domestic & Bottle glass, brown & & 19 & 19 & 96.50 \\
\hline 80 & $F-1$ & & 77 & 1 & $0-6^{\prime \prime}$ & $3 \times 4 \mathrm{ft}$ & Domestic & Bottle glass, brown & & 1 & 1 & 4.10 \\
\hline 80 & $F-1$ & & 77 & 1 & $0-6^{\prime \prime}$ & $3 \times 4 \mathrm{ft}$ & Domestic & Vessel glass, clear & & 1 & 1 & 4.20 \\
\hline 80 & $\mathrm{~F}-1$ & & 77 & 1 & $0-6^{\prime \prime}$ & $3 \times 4 \mathrm{ft}$ & Miscellaneous & Charcoal & & & 0 & 0.10 \\
\hline 80 & $\mathrm{~F}-1$ & & 77 & 1 & $0-6^{\prime \prime}$ & $3 \times 4 \mathrm{ft}$ & Workshop & Horseshoe nail & 3 & & 3 & 2.90 \\
\hline 80 & $\mathrm{~F}-1$ & & 77 & 1 & $0-6^{\prime \prime}$ & $3 \times 4 \mathrm{ft}$ & Workshop & Horseshoe nail & 1 & & 1 & 4.10 \\
\hline 80 & $F-1$ & & 77 & 1 & $0-6^{\prime \prime}$ & $3 \times 4 \mathrm{ft}$ & Workshop & Iron cutting & & 1 & 1 & 56.20 \\
\hline 81 & $\mathrm{~F}-1$ & & 78 & 1 & $0-6 "$ & $3^{\prime} \times 5^{\prime}$ & Workshop & Slag nodule & & 2 & 2 & 3.00 \\
\hline 81 & $F-1$ & & 78 & 1 & $0-6 "$ & $3 \times 5 \mathrm{ft}$ & Activities & Slate & 1 & & 1 & \\
\hline 81 & $F-1$ & & 78 & 1 & $0-6^{\prime \prime}$ & $3 \times 5 \mathrm{ft}$ & Construction & Cut nail & 11 & 13 & 24 & 59.00 \\
\hline 81 & $F-1$ & & 78 & 1 & $0-6 "$ & $3 \times 5 \mathrm{ft}$ & Construction & Flat washer & 1 & & 1 & \\
\hline 81 & $\mathrm{~F}-1$ & & 78 & 1 & $0-6 "$ & $3 \times 5 \mathrm{ft}$ & Construction & Square nut w/bolt frag & & 1 & 1 & 67.80 \\
\hline 81 & $\mathrm{~F}-1$ & & 78 & 1 & $0-6 "$ & $3 \times 5 \mathrm{ft}$ & Construction & Window glass, $3 \mathrm{~mm}$ & & 1 & 1 & 0.20 \\
\hline 81 & $F-1$ & & 78 & 1 & $0-6^{\prime \prime}$ & $3 \times 5 \mathrm{ft}$ & Domestic & Bottle glass, aqua & & 2 & 2 & 6.00 \\
\hline 81 & $\mathrm{~F}-1$ & & 78 & 1 & $0-6^{\prime \prime}$ & $3 \times 5 \mathrm{ft}$ & Domestic & Bottle glass, brown & & 25 & 25 & 29.00 \\
\hline 81 & $\mathrm{~F}-1$ & & 78 & 1 & $0-6^{\prime \prime}$ & $3 \times 5 \mathrm{ft}$ & Domestic & Bottle glass, clear & & 1 & 1 & 3.50 \\
\hline 81 & $\mathrm{~F}-1$ & & 78 & 1 & $0-6^{\prime \prime}$ & $3 \times 5 \mathrm{ft}$ & Faunal & Bone, Mammal & & 1 & 1 & 0.46 \\
\hline 81 & $\mathrm{~F}-1$ & & 78 & 1 & $0-6^{\prime \prime}$ & $3 \times 5 \mathrm{ft}$ & Workshop & Horseshoe nail & 2 & 3 & 5 & 16.00 \\
\hline 81 & $\mathrm{~F}-1$ & & 78 & 1 & $0-6^{\prime \prime}$ & $3 \times 5 \mathrm{ft}$ & Workshop & Slag nodule & & 42 & 42 & 128.00 \\
\hline 82 & $\mathrm{~F}-1$ & & 79 & 1 & $0-6^{\prime \prime}$ & $3 \times 5 \mathrm{ft}$ & Workshop & Wire & & 1 & 1 & 26.00 \\
\hline 82 & $F-1$ & & 79 & 1 & $0-6^{\prime \prime}$ & $3 \times 7 \mathrm{ft}$ & Construction & Cut nail & 1 & & 1 & 2.40 \\
\hline 82 & $\mathrm{~F}-1$ & & 79 & 1 & $0-6^{\prime \prime}$ & $3 \times 7 \mathrm{ft}$ & Domestic & Bottle glass, brown & & 1 & 1 & 0.20 \\
\hline 82 & $\mathrm{~F}-1$ & & 79 & 1 & $0-6^{n}$ & $3 \times 7 \mathrm{ft}$ & Domestic & Vessel glass, cle ar & & 9 & 9 & 4.60 \\
\hline 82 & $|\mathrm{~F}-1|$ & & 79 & 1 & $0-6 "$ & $3 \times 7 \mathrm{ft}$ & Faunal & Bone, Lepus californ. & 1 & & 1 & 0.41 \\
\hline
\end{tabular}


Table B-1. continued

\begin{tabular}{|c|c|c|c|c|c|c|c|c|c|c|c|c|}
\hline $\begin{array}{l}\dot{0} \\
z_{00} \\
\tilde{m}\end{array}$ & 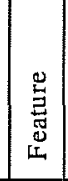 & $\begin{array}{l}\text { 蹗 } \\
\text { 总 } \\
\text { 兵 }\end{array}$ & 茅 & অ & $\begin{array}{l}\text { 咅 } \\
\text { ه }\end{array}$ & 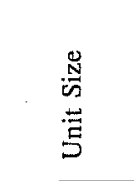 & 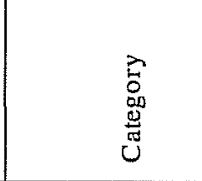 & 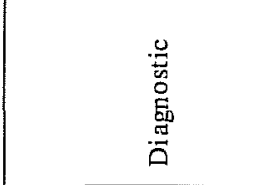 & 咆 & 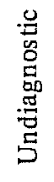 & 离 & 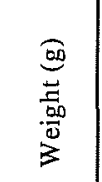 \\
\hline 82 & $\mathrm{~F}-1$ & & 79 & 1 & $0-6^{\prime \prime}$ & $3 \times 7 \mathrm{ft}$ & Lithics & Flake & & 3 & 3 & 1.20 \\
\hline 82 & F-1 & & 79 & 1 & $0-6^{\prime \prime}$ & $3 \times 7 \mathrm{ft}$ & Miscellaneous & Charcoal & & & 0 & 0.10 \\
\hline 82 & $F-1$ & & 79 & 1 & $0-6^{\prime \prime}$ & $3 \times 7 \mathrm{ft}$ & Miscellaneous & Metal frag & & 3 & 3 & 1.20 \\
\hline 82 & $\mathrm{~F}-1$ & & 79 & 1 & $0-6^{\prime \prime}$ & $3 \times 7 \mathrm{ft}$ & Miscellaneous & Mussel shell & & 1 & 1 & 1.20 \\
\hline 82 & F-1 & & 79 & 1 & $0-6^{\prime \prime}$ & $3 \times 7 \mathrm{ft}$ & Workshop & Iron cutting & & 1 & 1 & 19.50 \\
\hline 83 & $\mathrm{~F}-1$ & & 80 & 1 & $0-6 "$ & $3 \times 7 \mathrm{ft}$ & Workshop & Wire & & 1 & 1 & 5.20 \\
\hline 83 & F-1 & & 80 & 1 & $0-6^{\prime \prime}$ & $3 \times 4 \mathrm{ft}$ & Domestic & Bottle glass, brown & 2 & 74 & 76 & 383.50 \\
\hline 83 & $F-1$ & & 80 & 1 & $0-6 "$ & $3 \times 4 \mathrm{ft}$ & Miscellaneous & Charcoal & & & 0 & 0.30 \\
\hline 83 & $\mathrm{~F}-1$ & & 80 & 1 & $0-6 "$ & $3 \times 4 \mathrm{ft}$ & Miscellaneous & Metal frag & & 4 & 4 & 19.00 \\
\hline 83 & $\mathrm{~F}-1$ & & 80 & 1 & $0-6^{\prime \prime}$ & $3 \times 4 \mathrm{ft}$ & Workshop & Horseshoe nail & 1 & 1 & 2 & 6.50 \\
\hline 83 & F-1 & & 80 & 1 & $0-6 "$ & $3 \times 4 \mathrm{ft}$ & Workshop & Iron cutting & & 1 & 1 & 22.50 \\
\hline 84 & $\mathrm{~F}-1$ & & 81 & 1 & $0-6 "$ & $3 \times 4 \mathrm{ft}$ & Workshop & Slag nodule & & 1 & 1 & 4.00 \\
\hline 84 & $\mathrm{~F}-1$ & & 81 & 1 & $0-6 "$ & $2.5 \times 3 \mathrm{ft}$ & Construction & Cut nail & 9 & 16 & 25 & 48.50 \\
\hline 84 & $\mathrm{~F}-1$ & & 81 & 1 & $0-6 "$ & $2.5 \times 3 \mathrm{ft}$ & Construction & Fencing staple & 2 & & 2 & 9.50 \\
\hline 84 & $F-1$ & & 81 & 1 & $0-6 "$ & $2.5 \times 3 \mathrm{ft}$ & Construction & Window glass, $3 \mathrm{~mm}$ & 3 & & 3 & 6.00 \\
\hline 84 & $\mathrm{~F}-1$ & & 81 & 1 & $0-6 "$ & $2.5 \times 3 \mathrm{ft}$ & Domestic & Bottle glass, aqua & & 3 & 3 & 5.50 \\
\hline 84 & F-1 & & 81 & 1 & $0-6^{\prime \prime}$ & $2.5 \times 3 \mathrm{ft}$ & Domestic & Bottle glass, brown & & 11 & 11 & 27.30 \\
\hline 84 & $\mathrm{~F}-1$ & & 81 & 1 & $0-6^{\prime \prime}$ & $2.5 \times 3 \mathrm{ft}$ & Domestic & Tin can, base and top & 2 & & 2 & 29.00 \\
\hline 81 & $\mathrm{~F}-1$ & & 81 & 1 & $0-6^{\prime \prime}$ & $2.5 \times 3 \mathrm{ft}$ & Miscellaneous & Metal frag & & 11 & 11 & 42.20 \\
\hline 84 & $F-1$ & & 81 & 1 & $0-6^{\prime \prime}$ & $2.5 \times 3 \mathrm{ft}$ & Miscellaneous & Metal frag & & 11 & 11 & 36.50 \\
\hline 84 & F-1 & & 81 & 1 & $0-6^{\prime \prime}$ & $2.5 \times 3 \mathrm{ft}$ & Workshop & Horseshoe & 1 & & 1 & 254.50 \\
\hline 84 & $\mathrm{~F}-1$ & & 81 & 1 & $0-6^{\prime \prime}$ & $2.5 \times 3 \mathrm{ft}$ & Workshop & Horseshoe nail & 1 & 3 & 4 & 11.50 \\
\hline 84 & $\mathrm{~F}-1$ & & 81 & 1 & $0-6^{\prime \prime}$ & $2.5 \times 3 \mathrm{ft}$ & Workshop & Iron cutting & & 1 & 1 & 16.50 \\
\hline 84 & $\mathrm{~F}-1$ & & 81 & 1 & $0-6^{\prime \prime}$ & $2.5 \times 3 \mathrm{ft}$ & Workshop & Slag nodule & & 30 & 30 & 83.00 \\
\hline 85 & $F-1$ & & 82 & 1 & $0-6^{\prime \prime}$ & $3 \times 3 \mathrm{ft}$ & Workshop & Wire & & 2 & 2 & 16.00 \\
\hline 85 & F-1 & & 82 & 1 & $0-6^{\prime \prime}$ & $3 \times 3 \mathrm{ft}$ & Construction & Cut nail & 1 & & 1 & 1.80 \\
\hline 86 & $\mathrm{~F}-1$ & & 83 & 1 & $0-6 "$ & $3 \times 3 \mathrm{ft}$ & Miscellaneous & Metal frag & & 4 & 4 & 14.50 \\
\hline 86 & $\mathrm{~F}-1$ & & 83 & 1 & $0-6 "$ & $3 \times 4 \mathrm{ft}$ & Construction & Cut nail & 1 & & 1 & 3.00 \\
\hline 86 & $\mathrm{~F}-1$ & & 83 & 1 & $0-6 "$ & $3 \times 4 \mathrm{ft}$ & Construction & Fencing staple & 1 & & 1 & 5.00 \\
\hline 87 & $F-1$ & & 84 & 1 & $0-6^{\prime \prime}$ & $3 \times 4 \mathrm{ft}$ & Domestic & Bottle glass, brown & & 8 & 8 & 12.90 \\
\hline 87 & $F-1$ & & 84 & 1 & $0-6^{\prime \prime}$ & $4 \times 4 \mathrm{ft}$ & Construction & Cut nail & 1 & 2 & 3 & 10.00 \\
\hline 87 & F-1 & & 84 & 1 & $0-6 "$ & $4 \times 4 \mathrm{ft}$ & Domestic & Bottle glass, aqua & & 13 & 13 & 42.00 \\
\hline 87 & F-1 & & 84 & 1 & $0-6^{\prime \prime}$ & $4 \times 4 \mathrm{ft}$ & Domestic & Bottle glass, brown & & 1 & 1 & 3.50 \\
\hline 87 & $\mathrm{~F}-1$ & & 84 & 1. & $0-6^{\prime \prime}$ & $4 \mathrm{x} 4 \mathrm{ft}$ & Faunal & Bone, Lg. Mammal & & 6 & 6 & 52.16 \\
\hline 87 & $\mathrm{~F}-1$ & & 84 & 1 & $0-6^{\prime \prime}$ & $4 \times 4 \mathrm{ft}$ & Faunal & Bone, Mammal & & 4 & 4 & 5.08 \\
\hline 87 & $F-1$ & & 84 & 1 & $0-6^{\prime \prime}$ & $4 \times 4 \mathrm{ft}$ & Faunal & Bone, Testudinata & 1 & & 1 & 2.06 \\
\hline 87 & $F-1$ & & 84 & 1 & $0-6^{\prime \prime}$ & $4 \times 4 \mathrm{ft}$ & Miscellaneous & Charcoal & & & 0 & 16.00 \\
\hline 87 & $\mathrm{~F}-1$ & & 84 & 1 & $0-6^{\prime \prime}$ & $4 \times 4 \mathrm{ft}$ & Workshop & Horseshoe & 1 & 1 & 2 & 486.00 \\
\hline 87 & $\mathrm{~F}-1$ & & 84 & 1 & $0-6 "$ & $4 \times 4 \mathrm{ft}$ & Workshop & Horseshoe nail & 2 & & 2 & 10.00 \\
\hline 88 & $F-1$ & & 85 & 1 & $0-6^{\prime \prime}$ & $4 \times 4 \mathrm{ft}$ & Workshop & Lead frag & & 1 & 1 & 3.50 \\
\hline 88 & $\mathrm{~F}-1$ & & 85 & 1 & $0-6^{\prime \prime}$ & $4 \times 4 \mathrm{ft}$ & Construction & Cut nail & 3 & 1 & 4 & 10.80 \\
\hline 89 & $F-1$ & & 86 & 1 & $0-6 "$ & $4 \times 4 \mathrm{ft}$ & Workshop & Horseshoe nail & 1 & 4 & 5 & 19.20 \\
\hline 89 & $\mathrm{~F}-1$ & & 86 & 1 & $0-6 "$ & $2 \times 4 \mathrm{ft}$ & Activities & Shell casing & & 1 & 1 & 2.50 \\
\hline
\end{tabular}


Table B-1. continued

\begin{tabular}{|c|c|c|c|c|c|c|c|c|c|c|c|c|}
\hline$\sum_{\substack{0 \\
\tilde{I}}}^{\dot{0}}$ & 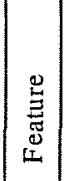 & 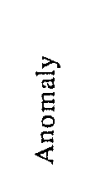 & 莕 & $\vec{\Xi}$ & $\begin{array}{l}\text { 吉 } \\
\stackrel{0}{0}\end{array}$ & 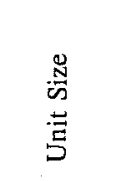 & $\begin{array}{l}\vec{b} \\
00 \\
\text { 品 } \\
\text { ت्ञ }\end{array}$ & 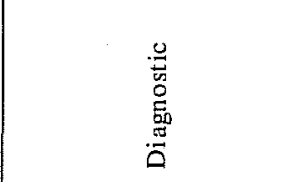 & E & 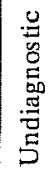 & 矛 & 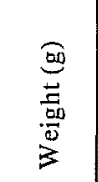 \\
\hline 89 & F-1 & & 86 & 1 & $0-6^{\prime \prime}$ & $2 \times 4 \mathrm{ft}$ & \begin{tabular}{|l} 
Construction \\
\end{tabular} & Cut nail & 3 & 5 & 8 & 9.90 \\
\hline 89 & $\mathrm{~F}-1$ & & 86 & 1 & $0-6^{\prime \prime}$ & $2 \times 4 \mathrm{ft}$ & Construction & Metal frag & 1 & & 1 & 202.00 \\
\hline 89 & $\mathrm{~F}-1$ & & 86 & 1 & $0-6^{\prime \prime}$ & $2 \times 4 \mathrm{ft}$ & Lithics & Flake & & 1 & 1 & 2.00 \\
\hline 89 & $\mathrm{~F}-1$ & & 86 & 1 & $0-6^{\prime \prime}$ & $2 \times 4 \mathrm{ft}$ & Miscellaneous & Metal frag & & 37 & 37 & 41.00 \\
\hline 89 & $\mathrm{~F}-1$ & & 86 & 1 & $0-6^{\prime \prime}$ & $2 \times 4 \mathrm{ft}$ & Workshop & Horseshoe nail & & 8 & 8 & 21.00 \\
\hline 89 & $\mathrm{~F}-1$ & & 86 & 1 & $0-6 "$ & $2 \times 4 \mathrm{ft}$ & Workshop & Iron cutting & & 6 & 6 & 182.00 \\
\hline 90 & $\mathrm{~F}-4$ & & 87 & 1 & $0-6 "$ & $3 \times 6 \mathrm{ft}$ & Workshop & Iron frag w/rivet & & 1 & 1 & 71.00 \\
\hline 90 & $\mathrm{~F}-4$ & & 87 & 1 & $0-6^{\prime \prime}$ & $3 \times 6 \mathrm{ft}$ & Activities & Cartridge, rifle & 1 & & 1 & 36.50 \\
\hline 90 & $F-4$ & & 87 & 1 & $0-6 "$ & $3 \times 6 \mathrm{ft}$ & Activities & Tin can, base & & 1 & 1 & 15.50 \\
\hline 90 & $\mathrm{~F}-4$ & & 87 & 1 & $0-6^{\prime \prime}$ & $3 \times 6 \mathrm{ft}$ & Construction & Cut nail & 1 & 1 & 2 & 5.50 \\
\hline 90 & $\mathrm{~F}-4$ & & 87 & 1 & $0-6^{\prime \prime}$ & $3 \times 6 \mathrm{ft}$ & Domestic & Bottle glass, clear & & 1 & 1 & 1.50 \\
\hline 90 & $\mathrm{~F}-4$ & & 87 & 1 & $0-6^{\prime \prime}$ & $3 \times 6 \mathrm{ft}$ & Miscellaneous & Metal frag & & 3 & 3 & 3.00 \\
\hline 90 & $\mathrm{~F}-4$ & & 87 & 1 & $0-6^{\prime \prime}$ & $3 \times 6 \mathrm{ft}$ & Personal & Button, Metal & 1 & & 1 & \\
\hline 90 & F-4 & & 87 & 1 & $0-6^{\prime \prime}$ & $3 \times 6 \mathrm{ft}$ & Personal & Insignia, Metal & 1 & & 1 & \\
\hline 91 & $\mathrm{~F}-4$ & & 88 & 1 & $0-6^{\prime \prime}$ & $3 \times 6 \mathrm{ft}$ & Workshop & Chain link & 1 & & 1 & 17.70 \\
\hline 91 & $\mathrm{~F}-4$ & & 88 & 1 & $0-6^{\prime \prime}$ & $2 \times 6 \mathrm{ft}$ & Construction & Cut nail & & 3 & 3 & 8.80 \\
\hline 91 & $\mathrm{~F}-4$ & & 88 & 1 & $0-6^{\prime \prime}$ & $2 \times 6 \mathrm{ft}$ & Construction & Window glass, $2 \mathrm{~mm}$ & 1 & & 1 & 0.50 \\
\hline 91 & $\mathrm{~F}-4$ & & 88 & 1 & $0-6^{\prime \prime}$ & $2 \times 6 \mathrm{ft}$ & Domestic & Bottle glass, clear & & 1 & 1 & 1.10 \\
\hline 91 & $F-4$ & & 88 & 1 & $0-6^{\prime \prime}$ & $2 \times 6 \mathrm{ft}$ & Lithics & Flake & & 1 & 1 & 1.00 \\
\hline 93 & $\mathrm{~F}-1$ & & 89 & 1 & $0-6^{\prime \prime}$ & $2 \times 6 \mathrm{ft}$ & Workshop & Horseshoe nail & 2 & & 2 & 7.70 \\
\hline 93 & $F-1$ & & 89 & 1 & $0-6^{\prime \prime}$ & $4 \mathrm{x} 4 \mathrm{ft}$ & Construction & Cut nail & 1 & & 1 & 3.30 \\
\hline 93 & $\mathrm{~F}-1$ & & 89 & 1 & $0-6^{\prime \prime}$ & $4 \times 4 \mathrm{ft}$ & Construction & Elec. insulator & & 1 & 1 & 22.00 \\
\hline 93 & $\mathrm{~F}-1$ & & 89 & 1 & $0-6^{\prime \prime}$ & $4 \times 4 \mathrm{ft}$ & Domestic & Lid frag & 1 & & 1 & 41.00 \\
\hline 93 & $\mathrm{~F}-1$ & & 89 & 1 & $0-6^{\prime \prime}$ & $4 \times 4 \mathrm{ft}$ & Domestic & Tin can & & 1 & 1 & 116.30 \\
\hline 93 & $F-1$ & & 89 & 1 & $0-6^{\prime \prime}$ & $4 \times 4 \mathrm{ft}$ & Miscellaneous & Metal frag & & 1 & 1 & 2.30 \\
\hline 94 & & $\mathrm{~A}-13$ & & Surf & $3-4^{\prime \prime}$ & & Construction & Window glass, $2 \mathrm{~mm}$ & 4 & & 4 & 1.50 \\
\hline 94 & & A-13 & & Surf & $3-4 "$ & & Domestic & Fork handle, metal & 1 & & 1 & \\
\hline 94 & & A-13 & & Surf & $3-4^{\prime \prime}$ & & Domestic & Vessel glass, clear & & 2 & 2 & 2.50 \\
\hline 95 & & $\mathrm{~A}-16$ & & Surf & $3-4^{\prime \prime}$ & & Mi scellaneous & Metal frag & & 2 & 2 & 4.00 \\
\hline 96 & & A-23 & & Surf & $3-4^{\prime \prime}$ & & Activities & Toy Marble, Glass & 1 & & 1 & \\
\hline 96 & & A-23 & & Surf & $3-4^{\prime \prime}$ & & Personal & Adornment, Metal Star & 1 & & 1 & \\
\hline 97 & & A-28 & & Surf & $3-4^{\prime \prime}$ & & Lithics & Chert & & 1 & 1 & 17.80 \\
\hline 98 & & A-29 & & Surf & $3-4^{\prime \prime}$ & & Construction & Cut nail & 1 & & 1 & 1.30 \\
\hline 98 & & A-29 & & Surf & $3-4^{\prime \prime}$ & & Lithics & Flake & & 1 & 1 & 0.80 \\
\hline 98 & & A-29 & & Surf & $3-4^{\prime \prime}$ & & Lithics & Flake & & 1 & 1 & 13.30 \\
\hline 99 & & A-30 & & Surf & $3-4^{\prime \prime}$ & & Construction & Tent stake w/eyelet & 1 & & 1 & 9.00 \\
\hline 99 & & A-30 & & Surf & $3-4^{\prime \prime}$ & & Construction & Tent stake w/eyelet & 1 & & 1 & 9.50 \\
\hline 99 & & A-30 & & Surf & $3-4^{\prime \prime}$ & & Construction & Tent stake & 1 & & 1 & 21.00 \\
\hline 101 & & $\mathrm{~A}-34$ & & Surf & $3-4^{\prime \prime}$ & & Miscellaneous & Mussel shell & & 2 & 2 & 0.80 \\
\hline 101 & & A-34 & & Surf & $3-4^{\prime \prime}$ & & Domestic & Vessel glass, clear & & 1 & 1 & 2.80 \\
\hline 102 & & A-39 & & Surf & $3-4 "$ & & Construction & Iron stake/nail & 1 & & 1 & 72.70 \\
\hline 103 & & A-41 & & Surf & $3-4^{\prime \prime}$ & & Personal & Button, Metal & 1 & & 1 & \\
\hline 104 & & A-42 & & Surf & $3-4^{\prime \prime}$ & & Miscellaneous & Mussel shell & & 3 & 3 & 6.50 \\
\hline
\end{tabular}


Table B-1. continued

\begin{tabular}{|c|c|c|c|c|c|c|c|c|c|c|c|c|}
\hline 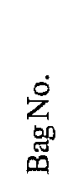 & 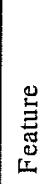 & 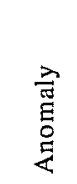 & 泀 & 岂 & $\begin{array}{l}\text { 䓌 } \\
\text { 号 }\end{array}$ & $\begin{array}{l}\text { D } \\
\text { 岕 } \\
\text { 芯 }\end{array}$ & 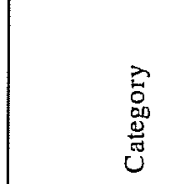 & 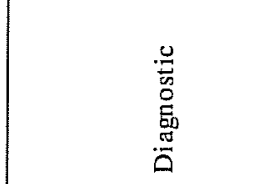 & $\underset{\Xi}{E}$ & 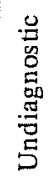 & 昰 & $\begin{array}{l}\text { क0 } \\
\overrightarrow{0} \\
.00 \\
.00 \\
\overrightarrow{3}\end{array}$ \\
\hline 78 & & A-42 & & Surf & $3-4^{\prime \prime}$ & & Personal & Button, Metal & 1 & & 1 & \\
\hline 101 & & A- 42 & & Surf & $3-4^{\prime \prime}$ & & Workshop & Horseshoe nail & 1 & & 1 & 4.50 \\
\hline 105 & & A-45 & & Surf & $3-4 "$ & & Construction & Cut nail & & 1 & 1 & 0.80 \\
\hline 106 & & A-54 & & Surf & Surf & & Domestic & Bottle glass, brown & & 1 & 1 & 2.80 \\
\hline 92 & & A-54 & & Surf & $3-4^{\prime \prime}$ & & Domestic & Bottle glass, clear & 1 & & 1 & 4.80 \\
\hline 107 & & A-55 & & Surf & $0-6^{\prime \prime}$ & & Workshop & Horseshoe nail & 2 & & 2 & 10.80 \\
\hline 109 & & A-57 & & Surf & $3-4^{\prime \prime}$ & & Lithics & Flake & & 1 & 1 & 6.10 \\
\hline 109 & & $\mathrm{~A}-57$ & & Surf & $3-4 "$ & & Construction & Cut nail & 2 & & 2 & 15.50 \\
\hline 109 & & A-57 & & Surf & $3-4^{\prime \prime}$ & & Personal & Button, Metal & 1 & & 1 & \\
\hline 110 & & A-64 & & Surf & $3-4^{\prime \prime}$ & & Domestic & Bottle glass, aqua & & 4 & 4 & 19.50 \\
\hline 110 & & $A-64$ & & Surf & $3-4^{\prime \prime}$ & & Domestic & Bottle glass, brown & 1 & & 1 & 49.80 \\
\hline 111 & & Surf & & Surf & $0-1 "$ & & Workshop & Horseshoe & 1 & & 1 & 375.50 \\
\hline 100 & & Surf & & Surf & $0-1 "$ & & Workshop & Horseshoe & 1 & & 1 & 301.00 \\
\hline
\end{tabular}

